\title{
LITERARY IMPRESSIONISMS
}

Resonances of Impressionism in Swedish and Finland-Swedish Prose 1880-1900

Camilla Storskog 



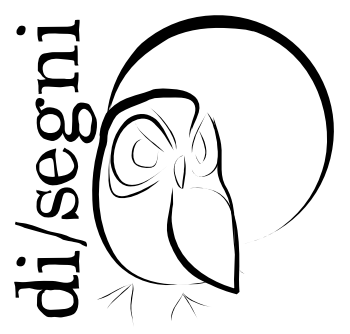





\section{LITERARY IMPRESSIONISMS}

\section{Resonances of Impressionism in Swedish and Finland-Swedish Prose 1880-1900}

Camilla Storskog

\section{di/segni}

Dipartimento di Lingue e Letterature Straniere

Facoltà di Studi Umanistici

Università degli Studi di Milano

Ledizioni 


\title{
(C) 2018 Camilla Storskog \\ ISBN 978-88-6705-724-5 \\ ILLUSTRAZIONE DI COPERTINA:
}

Laurits Andersen Ring, Ung pike ser ut av et takvindu (I885; Girl Looking out of a Skylight). Oil on canvas. 33,34 x 45, 6 cm.

Photo: Dag A. Ivarsøy,

(C)The National Museum of Art, Architecture and Design, Oslo.

$\mathrm{n}^{0} 25$

Collana sottoposta a double blind peer review

ISSN: 2282-2097

\section{Grafica:}

Raúl Díaz Rosales

Composizione:

Ledizioni

Disegno del logo:

Paola Turino

\author{
STAMPATO A MILANO \\ NEL MESE DI MAGGIO 2018 \\ www.ledizioni.it \\ www.ledipublishing.com \\ info@ledizioni.it \\ Via Alamanni 11 - 20141 Milano
}

\begin{abstract}
Tutti i diritti d'autore e connessi sulla presente opera appartengono all'autore. L'opera per volontà dell'autore e dell'editore è rilasciata nei termini della licenza Creative Commons 3.0, il cui testo integrale è disponibile alla pagina web http://creativecommons.org/licenses/by-sa/3.0/it/legalcode
\end{abstract}




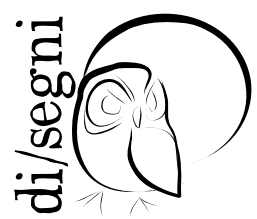

\title{
Condirettori
}

Monica Barsi e Danilo Manera

\section{Comitato scientifico}

\author{
Nicoletta Brazzelli Francesca Orestano \\ Marco Castellari Carlo Pagetti \\ Laura Scarabelli Nicoletta Vallorani \\ Andrea Meregalli Raffaella Vassena \\ Giovanni Iamartino
}

\section{Comitato scientifico internazionale}

\author{
Albert Meier Sabine Lardon \\ (Christian-Albrechts-Universität zu Kiel) (Université Jean Moulin Lyon 3) \\ Luis Beltrán Almería Aleksandr Ospovat - Александр Осповат \\ (Universidad de Zaragoza) (Высшая Школа Экономики - Москва) \\ Patrick J. Parrinder \\ (Emeritus, University of Reading, UK)
}

\section{Comitato di redazione}

Sara Sullam Simone Cattaneo

Valentina Crestani Elisa Alberani

Nataliya Stoyanova Angela Andreani 



\section{Table of contents}

INTRODUCTION

I. ON THE USEFULNESS OF LOCATING IMPRESSIONISM IN SWEDISH PROSE ............. I3

2. A PLEA FOR PLURALISM ……...........................................................................

3. WHAT IS LITERARY IMPRESSIONISM? ...........................................................

4. A FIELD THAT STILL REQUIRES INVESTIGATION .................................................. 8

5. ACTS OF RECONSTRUCTION ............................................................................. I9

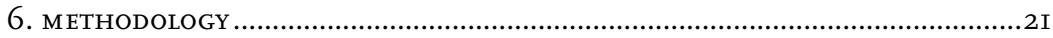

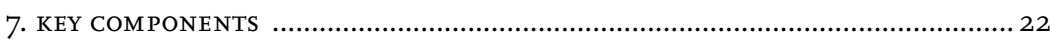

PART I: LITERARY IMPRESSIONISM. A VARIETY OF CONCERNS ….............................. 27

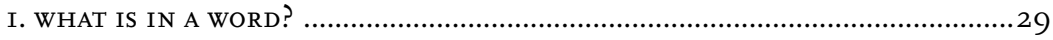

2. REVIEW OF PREVIOUS RESEARCH......................................................................

2.I. French literature .............................................................................. 32

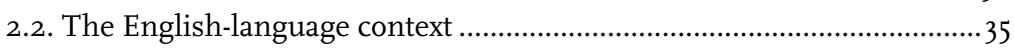

2.3. Scandinavia............................................................................................

3. LITERARY IMPRESSIONISM: THE HANDBOOK DEFINITIONS ................................... 39

4. HIGHLIGHTS IN THE SCANDINAVIAN DEBATE ON LITERARY IMPRESSIONISM ..... 47

4.I. Herman Bang's poetics of impressionism: den fremstillede Roman .........48

4.2. The age of impressionism and the Bohème ........................................57

4.3. August Strindberg and impressionism................................................... 67 
5. LITERARY IMPRESSIONISM AND FINLAND. A CRITICAL DIGEST ….........................79

5.I. Gustaf af Geijerstam ..............................................................................8I

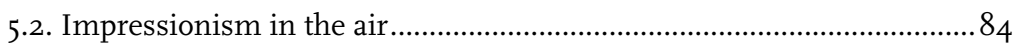

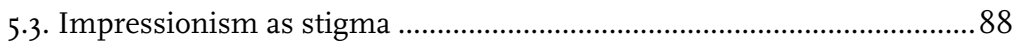

5.4. Mikael Lybeck, K.A. Tavaststjerna ………….......................................... 90

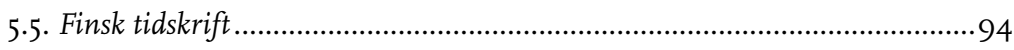

5.6. Concluding remarks ............................................................................98

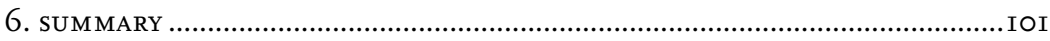

PART II: MODES OF LITERARY IMPRESSIONISM. TEXTUAL ANALYSES ......................IO3

I. TRAJECTORIES INTO THE HEART OF THE MATTER ….................................. IO

2. IMPRESSIONISM AS LITERARY PICTORIALISM: HELENA WESTERMARCK.............. IO9

2.I. Aftonstämning: the verbal re-modelling of the impressionist

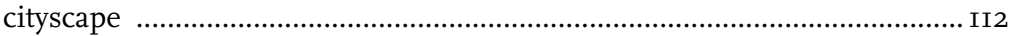

2.2. Westermarck and impressionism ...................................................II3

2.3. The ekphrastic model ...........................................................................

2.4. Impressionism in Aftonstämning. The motif: Paris from a window....... II9

2.5. Conclusion: form and content ............................................................127

3. THE NARRATIVE METHODS OF THE RENDERING OF IMPRESSIONS: STELLA KLEVE.......I3I

3.I. Stella Kleve and literary impressionism ............................................... 132

3.2. Stella Kleve and Herman Bang ..........................................................136

3.3. The dimensions of Stella Kleve's impressionism ................................... 139

4. A CRITICISM OF CRITICISM: GEORG NORDENSVAN AND MIKAEL LYBECK..............I59

4.I. Georg Nordensvan's Skuggspel. Tidsbilder ............................................159

4.2. Mikael Lybeck's Allas vår Margit and Den starkare ................................. $6_{3}$

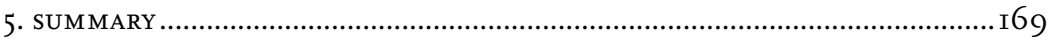

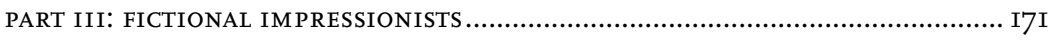

I. INTRODUCTION: THE IMPRESSIONIST AS A LITERARY CHARACTER.................... I73

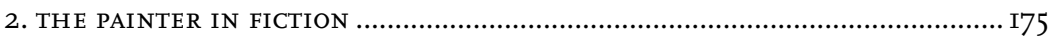

2.I. Gustaf af Geijerstam: Utan pängar ............................................... I77

2.2. Mathilda Roos: Familjen Verle. En skildring...................................... I88

2.3. Georg Nordensvan: Aja ................................................................ I94

3. THE PHENOMENOLOGICAL IMPRESSIONIST .............................................. 205

3.I. K.A. Tavaststjerna: Impressionisten .................................................208

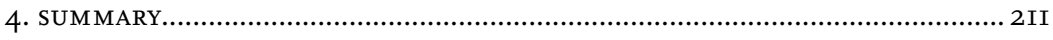

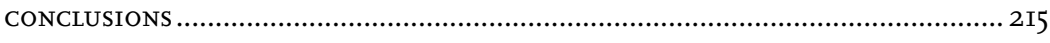

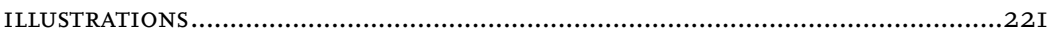

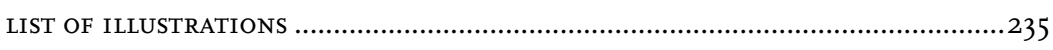

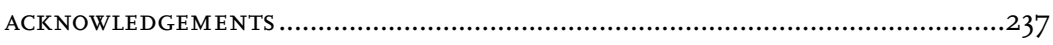

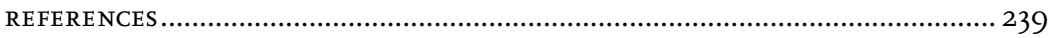


"It seems very pretty," she said [...], "but it's rather hard to understand!" (You see she didn't like to confess, even to herself, that she couldn't make it out at all.) "Somehow it seems to fill my head with ideas - only I don't exactly know what they are!"

L. Carroll, Through the Looking-Glass and What Alice Found There (1871) 



\section{INTRODUCTION}

\section{ON THE USEFULNESS OF LOCATING IMPRESSIONISM IN SWEDISH PROSE}

There are cultural contexts within which impressionism is acknowledged as a significant literary tendency. Swedish literature is not one of these. Histories and overviews of literature written in the Swedish language, whether produced in Sweden or in Finland, do not include units on literary impressionism - unlike the state of affairs in countries such as Austria, Denmark, or Germany. This is not an attempt to rewrite the history of Swedish literature. What follows is rather an effort to clarify to what extent impressionism resonated in Swedish and Finland-Swedish prose at the end of the nineteenth century and what facets it took on in literary writing. In other words, through the examination of texts that in various ways are considered to reveal an impact of impressionism, this book aims to provide an understanding of the numerous dimensions of literary impressionism. In addition, the writers' awareness of impressionism, both in its painterly and philosophical implications, will also be investigated through a body of texts written in Swedish and featuring impressionists as fictional characters.

In wider contexts, where literary impressionism might not be a canonized category but where the notion is, at any rate, discussed, an agreement on what it encapsulates - in terms of subjects, narrative techniques, and writers concerned - as well as on its usefulness in literary criticism, has by no means been reached. Recurring definitions of literary impressionism originating for instance from a French, an English-speaking, or a Norwegian perspective, offer a wide spectrum of interpretative possibilities of the concept, ranging, for example, from interart analogies to plotless sketches and fragments, from phenomenological apperception to philosophical concerns, from questions of grammar to matters of style. Not to mention the fact that the notion is repeatedly used as a stigma to indicate disconnected 
and insubstantial pieces of prose, and continually encounters the perplexity of scholars and literary critics within whose circles it, nonetheless, first emerged. Therefore, it cannot be denied that dedicating a study to the exploration of the 'elusive' concept of literary impressionism within a context that officially does not recognize its significance, has at times felt like walking on the edge of a slippery margin, the risk being, on the one hand, that of venturing into a discourse as vague and fleeting as many of the definitions of the notion itself and, on the other, that of overstating the case. Nevertheless, it has been my ambition to clarify an aspect of modern realism and its manifestation in and acclimatization to a literature geographically on the fringes of the European scene, far from the birthplace of its painterly counterpart. By concentrating on Swedish and Finland-Swedish literature, it is my hope to have supplemented the international discussion on the theme with a new perspective and conferred additional, extensive - perhaps even contrastive facets to the phenomenon of literary impressionism.

In particular, it has been my objective to produce a piece of writing thorough enough to refine the discourse on the impact of impressionism on Scandinavian literature, hitherto chiefly limited to an engagement with the Danish and the Norwegian literary scene. In general, I hope to have made a valid contribution to the greater transnational debate on a topic that in recent times, as we will see, is enjoying increased attention. If I have succeeded in my ambition, the challenging effort to locate and draw out resonances of impressionism in Swedish and Finland-Swedish prose has been worthwhile.

\section{A PLEA FOR PLURALISM}

On the subject of the preface in collections of miscellany, Gérard Genette regretfully states that one of its main functions is to compensate, «par une sorte de point d'honneur théorique» (1987: ı88; «by way of some kind of theoretical point of honour») ${ }^{1}$, for the lack of formal or thematic unity. As the scholar subsequently proceeds to claim his right to put in a good word for the value of plurality and diversity, the message is clear: «pourquoi l'unité serait-elle par principe supérieure à la multiplicité? [...] on aimerait pouvoir opposer à cette valorisation presque universelle de l'unité un thème inverse de valorisation de la diversité» (I987: 189; «why should unity, on principle, be preferable to multiplicity? [...] to this almost universal appreciation of unity one would like to be able to oppose the inverse theme of the appreciation of diversity»).

These are words of solace to the one standing on the threshold of an introductory discourse on the concept of literary impressionism. The vast

I All translations are mine, unless otherwise indicated. 
body of texts and the miscellaneous mannerisms that, globally, gather under the heading of literary impressionism undoubtedly point in the direction of an acceptance and a study of this critical category as a pluralistic umbrella term. Therefore, in contrast to those scholars who have approached the idea of impressionism in literature in diverse and highly individual ways, and produced writings that reflect their personal interpretations of the phenomenon, what this study has strived to obtain is not so much an unequivocal (re)definition of the term as deductive, methodological pluralism. As Hans Lund (1982: I94), whose works on the interrelation between art and literature have been a source of inspiration for the present investigation in many ways, quite simply puts it: «different texts and different authors pose different problems, which makes it necessary for the student to regulate his instruments of analysis all the time».

Additionally, on the subject of investigating the use of literary impressionism as a province of the critics, Lund (I993: 7-8) rejects the need for an instantly recognizable, or even personal, redefinition of the term, and instead considers it fruitful to study «de skiftande aspekter som anläggs och genom åren har anlagts på begreppet litterär impressionism, aspekter som har dikterats av eller emanerat ur i tid och rum skiftande kontexter, normer och koduppsättningar» (I993: 8; «the shifting aspects that are being applied to and that have, through the years, been applied to the concept of literary impressionism, aspects that have been dictated by or have emanated out of contexts, norms and combinations of codes, shifting in time and space»).

In summary, my course of action builds on the need to study literary impressionism - instead of reinventing it.

Likewise, the discussion of painterly impressionism runs to the rescue of a pluralistic theoretical approach. «Individualism» instead of «impressionism» - as determined by the Swedish writer and art critic Georg Nordensvan (I890: 48I), whose own literary method, as we will see, had been judged as dependent on the modes of impressionist painting - was, according to Nordensvan, a more appropriate definition with which to approach the art of the modern painters. More than a hundred years later Elisabeth LièvreCrosson formulated herself correspondingly: «l'impressionnisme est avant tout une expression individuelle. Chacun applique ses principes comme il l'entend» (I999: I2-I3; «impressionism is above all an individual expression. Each and every one applies its principles as they understand them»). When Verner von Heidenstam and Oscar Levertin in the famous pamphlet Pepitas bröllop. En literaturanmälan (Heidenstam and Levertin I890: 42; Pepitas Wedding. A Literary Review) established as the ultimate goal of the new literature of the I 890 os precisely the imitation of the individualism of the modern painters, they hinted at the interrelation between the visual arts and literature, which is of central concern to the discussion of literary impressionism, as we will see. 
Along these lines, the following discourse on literary impressionism departs from the idea that impressionist texts and impressionist writers should not be seen as connected by one fundamental common feature, and instead assumes what could be defined as a 'polythetic' approach to the classification of these writings and authors. By briefly mentioning Ludwig Wittgenstein's philosophical concept of «family resemblance» as a suitable analogy for explaining the multiplicity of literary impressionism, Paul B. Armstrong, in a review of Peter H. Stowell's Literary Impressionism. James and Chekov (Armstrong I980: 384), directed my attention to this possible approach to the issue investigation. Wittgenstein's idea of Familienähnlichkeit ('family resemblance'), developed in his work Philosophical Investigations (Wittgenstein I953) as a means of linking numerous uses of one and the same word, seems in fact particularly apt to help organize a discourse of a literary mode variously understood as a concern with perception, both philosophical and artistic, as the superseder of naturalism, as literary behaviourism, as a modernist stream-of-consciousness technique, and as interart transposition.

In his attempt to get to the essence of language, Wittgenstein (I953: 3Ie) describes the concept of Familienähnlichkeit by recurring to the metaphor of games - «board-games, card-games, ball-games, Olympic games» - and invites the reader to find out whether there is something common to all these varieties of games. Wittgenstein's answer is that there are similarities, correspondences, and relationships between the activities that we call games, although no single characteristic feature central and common to all expressions of the concept of 'games' is to be found. Instead, he claims (I953: 32e), we should think of the word 'games' as «a complicated network of similarities over-lapping and criss-crossing, sometimes overall similarities, sometimes similarities of detail». He explains:

I can think of no better expression to characterize these similarities than 'family resemblances'; for the various resemblances between members of a family: build, features, colour of eyes, gait, temperament, etc. etc. overlap and criss-cross in the same way. - And I shall say: 'games' form a family. (1953: 32e)

However soothing Genette's homage to multiplicity and Wittgenstein's concept of Familienähnlichkeit might be, there is still a fly in the ointment. And it buzzes about the question of the usefulness of grouping together a selection of heterodox texts under a common label most often created by literary critics, which, as has been observed by detractors unwilling to speak of impressionist writing as a category, runs the risk of being much too flexible to be functional. In response, I would like to return to Wittgenstein's philosophical investigations and also refer to the results stemming from the 
empirical survey of the use of the term in literary criticism accomplished in the present study. Firstly, Wittgenstein's idea of «family resemblance» stresses the point that any word really corresponds to «a family of meanings» (I953: 36e) and his concept is furthermore indicative of the, not necessarily negative, inaccuracy and blurred boundaries that come with different employments of the same notion:

\begin{abstract}
One might say that the concept 'game' is a concept with blurred edges. - "But is a blurred concept a concept at all?" - Is an indistinct photograph a picture of a person at all? Is it even always an advantage to replace an indistinct picture by a sharp one? Isn't the indistinct one often exactly what we need? (I953: $36 \mathrm{e}$ )
\end{abstract}

Secondly, this inquiry into literary impressionism departs from the pages of literary criticism written in the 'age of impressionism', in which the usage and the reflection on the meaning of the term in point of fact moved in several directions at one and the same time. My venture has been to mirror this reality.

It is my belief that an approach to the understanding of literary impressionism which stems from the critics' different approaches to the concept in combination with the writers' diverse appropriations of and reflections on the tendency is valuable. If this leaves us with a result reflecting a multiplicity of interpretations of the concept of literary impressionism, the usefulness of this approach still remains. More to the point, if we resolved the difficulty of pinning down the definitions by simply expelling the term from the vocabulary, as has been suggested (Brown i968: 59; Cuddon i991: 446), how shall we name the various formulas that are known as literary impressionism?

\title{
3. WHAT IS LITERARY IMPRESSIONISM?
}

The answers to the question, whether based on the proximity to the visual arts, on philosophical groundings, or simply on a resistance to acknowledge the phenomenon, seem to flourish. Is literary impressionism about narrative techniques such as achronological narration, the representation of «the immediate epistemological experience» (Peters 2001: 24); in medias res, the author's filtering of phenomena through the consciousness of one observer; the reader's and the narrator's simultaneous discovery of information; a central consciousness with a limited point of view instead of an omniscient narrator; or, multiple narrators? (Peters 200I: 22-27). Or is it, instead, synonymous with suggesting mood and atmosphere? Is it about the fragmentation of form? Of plot? Point of view? Individual perception 
as opposed to universal conventions? Transposition of painterly impressionism? Linguistic characteristics? Philosophical concerns? All of this, or nothing? According to John G. Peters, «much has been written about literary impressionism, but despite this body of commentary the movement remains amorphous, so much so that those definitions that do exist are themselves usually 'impressionistic'» (Peters 200I: I3). He continues: «the problem with existing work on literary impressionism is that it either restricts the movement's subject matter and methodology thereby ignoring crucial characteristics of impressionist literature, or expands the canon to include too many dissimilar authors» (Peters 200I: I4).

With the conviction that the keys to understanding literary impressionism are manifold, this study departs from a focus on literary criticism written in Swedish at the turn of the nineteenth century in a bid to find an answer. Did literary impressionism exist in Swedish literature? On what terms? How was it interpreted and how can it be defined? Who are the writers connected with this literary mode? Which are the central works? The examination of the concept is further achieved through close readings of a selection of texts, singled out as significant examples of impressionist literary modes partly with the help of the opinions expressed in the literary criticism that has been scrutinized for this study.

\section{A FIELD THAT STILL REQUIRES INVESTIGATION}

To the extent that literary impressionism has been discussed with reference to works of prose and poetry written in Swedish, contributions to a profound critical reflection on the subject can rightly be defined as negligible. In the I950s, Karl-Erik Lundevall commented as follows on the notion of literary impressionism and Swedish prose: «i den litterära debatten i Sverige på 8o-talet trängde begreppet aldrig igenom, och ingen av åttitalisterna blev annat än möjligen sporadiskt katalogiserad som impressionist» (I953: 240: «in the literary debate of the Swedish I88os the concept never quite broke through, and none of the writers of this generation were, with the exception of possible sporadic occasions, labelled as impressionists»). Following his words of praise for Sven Møller Kristensen's systematic study of literary impressionism in Danish prose (Møller Kristensen I938), Lundevall admits, however, that the question has not quite been probed within a Swedish context: «för svensk litteratur saknas tyvärr några motsvarande utredningar» (I953: 240; «unfortunately no similar investigations have been applied to Swedish literature»). In I970, Peter Hallberg would reiterate the same regret (Hallberg I970: 258).

In I993, however, the Swedish scholar Hans Lund published a meticulous study with a global perspective on the history and usage of the term 'literary impressionism', one of the aims of which was to practise «hjärt- 
massage på den skandinaviska impressionismdebatten» (Lund I993: I2; «cardiac massage on the Scandinavian impressionism debate»). In spite of Lund's seminal work, Scandinavian studies on the concept of literary impressionism have only partly, and undoubtedly not yet adequately, explored its usage and significance in Swedish literature, as we will see. Moreover, no effort to assess the resonances and the role of impressionism in FinlandSwedish literature has so far been made.

The lack of a scholarly tradition investigating literary impressionism in relation to fiction written in Swedish is regrettable considering the long history of the international debate on the theme and, especially, if taking into account its recently registered vivacity within the French and the English-speaking cultural contexts (see, e.g., Bowler 2016; Berrong 2013; Gengembre, Leclerc and Naugrette 20I2; Parkes 20II; Pouzet-Duzer 2013; Saunders 2OII and 20I3; Vouilloux 20I2b). Therefore, what the following pages attempt to add to the ongoing international discussion on the theme is an understanding of the impact of impressionism on literature written in Swedish by way of considering literary impressionism as an inclusive and comprehensive notion, corresponding to its earliest usage in Swedish literary criticism, and not by presenting a personal vision of the substance of the term. This is not to say that critical redefinitions of impressionism in literature need to be ruled out. However, given the marginal attention paid to the study of the phenomenon in relation to Swedish literary texts, the present approach to the question has been deemed the most pragmatic. The dissection of how the term is variously encountered in literary criticism and in the writers' reflections on the theme is accompanied by close readings of texts that have been singled out in order to highlight different ways of characterizing impressionism in literature and its formal or stylistic aspects. Each text is believed to reveal distinctive aspects of literary impressionism and each reading explores specific impressionist techniques.

\section{ACTS OF RECONSTRUCTION}

Along these lines, the present study is not aiming at a personal redefinition of literary impressionism like the one Jesse Matz strives to elaborate in his volume Literary Impressionism and Modernist Aesthetics (Matz 200I). Nor does it aspire to link this tendency exclusively to one of the key issues of literary impressionism, to interart comparison, or to narrative techniques, or to philosophical theories of perception. Rather, it wishes to represent acts of reconstruction. As such, it has taken two main directions: firstly, the description of what the idea of literary impressionism meant to critics and writers operating in «the age of impressionism» (Hauser I999: I78), which has consequently led to the identification of those writers and those texts 
that were, at the time, considered representative of the tendency. Secondly, it proceeds to an in-depth analysis of aspects in the identified texts that supposedly draw on the modes of literary impressionism.

By departing from suggestions in critical writings, my objective has been to put across different lines of interpretation of impressionist prose. However, the main body of the textual analysis proposed in part two of the present study, represented by Helena Westermarck and Stella Kleve, is independent of the results stemming from the diachronic examination of the use of the term in the literary criticism evaluated in part one. As we will see, the critical views on literary impressionism exhibited in the press do not always reveal a profound understanding of the phenomenon and often seem to depend on the reviewer's private associations of what the term might encapsulate and on a superficial analysis of the literary works discussed. Although interesting from the point of view of the issue investigation, many of these brief critical commentaries claiming to find the legacy of impressionism in the texts that are discussed in the reviews are personal evocations that, in my opinion, often fail deeper scrutiny. To supplement the investigation into Westermarck's and Kleve's impressionist prose, I also explore what I have reputed the most relevant suggestions offered by these critical reviews, namely the ones regarding impressionist qualities in Georg Nordensvan's and Mikael Lybeck's works.

Literary impressionism is here thus investigated as a category present in the prose of a specific period, that of the last two decades of the nineteenth century, although «the aesthetic idea of impressionism» (Venturi I94I) is undeniably visible in artistic creations of greatly different eras. As Bernard Vouilloux has observed in a recent contribution to the critical discourse on literary impressionism, «dans le contexte des études littéraires, il n'est pas rare que des catégories originellement historiques, comme celles de baroque, de classique, de romantique ou d'impressionnisme, fonctionnent de manière transhistorique» (Vouilloux 20I2: 5; "within the context of literary studies, it is not rare that categories originally historical, such as baroque, classicism, romanticism or impressionism function in a transhistorical way») ${ }^{2}$. Accordingly, and as we will see, in the body of commentary that interests the Scandinavian discourse on literary impressionism, the eighteenth-century Swedish poet Carl Michael Bellman is sometimes, as to the nature of his apperception and style, indicated as one of the greatest impressionists in Scandinavian prose, alongside the prose of the seventeenth-century Danish royalty Leonora Christina. Similarly, in the twentieth century, the Norwegian writer Cora Sandel has been seen as an author who has transferred impressionism into modernist writing. However, for the purpose of my investigation here, the discussion is limited to the years in which painterly impressionism gained ground in the Nordic countries as a creative impulse with a potential to fuel the cultural debate.

2 See also Berndt Olsson's article discussing epochal styles, Olsson I983. 


\section{METHODOLOGY}

The decoding of the concept of literary impressionism takes as its starting point a survey of the use of the term in the literary criticism of a limited period, i.e., approximately I870-I9IO, written in Swedish. The restriction of the field of investigation to these years has depended upon the results of the examination of the electronically accessible digital archives of the Finnish Historical Newspaper Library3. The search results demonstrated that the occurrence of the term was most frequently concentrated to the years I880I900, when the pictorial movement (from which literary impressionism at least drew its nominal inspiration) developed and spread worldwide, not the least through the presence of foreign artists living and working in France.

Special attention had to be given to the use of the adjective impressionistisk in order to avoid the risk of over-interpretation. When Erik Hedén in the article Siri von Essen (Hedén I920) writes about the correspondence between August Strindberg and his first wife, he speaks of their letters thus: «hos båda samma impressionistiska stil, samma oförmåga att skriva lugnt och jämnt. Bådas brev överflöda av tank-streck» («in both we find the same impressionistic style, the same inability to write calmly and evenly. The letters of the two overflow with dashes»). The adjective 'impressionistic' is here used without specifically referring to the style, methods or techniques of the current in the arts (painting, literature, music) but rather as a synonym for 'spontaneous' or 'unstructured', which, of course, again turns back to the visual arts as these words correspond to the early view of what was one of the main 'flaws' in impressionist painting. This meaning of the adjective is, however, certainly adaptable to the prose of any period, although its use is perhaps likely to be more frequent in the wake of the artistic movement that emerged in the early i87os. By contrast, as Jesse Matz (20II: II6) puts it in a recent criticism of Colm Tóibín's and Michael Cunningham's attempts to restore the impressionism of Henry James and Virginia Woolf, «impressionism was never merely impressionistic».

It is only natural that the concept of impressionism should have influenced the critical writing on literature especially at the time of the painterly current's greatest fame and fortune. With the pretension of mirroring reality, I have relied on the variety and richness of the definitions of literary impressionism offered by the press in order to avoid restricting the understanding of the term to a fixed formula, destined to exemplify one aspect of the notion only. The attempt to find models, examples and protagonists representative of the various tendencies of literary impressionism in Swedish literature has been done, I repeat, with the claim of reflecting the multiform interpretative possibilities of a concept that was a reality at the time.

The pluralistic approach to the analysis of literary impressionism chosen

3 Available at http://digi.lib.helsinki.fi/sanomalehti/search. Accessed 7 February 2018. 
for this study has led, where necessary, to separate discussions of method in each section. This is particularly true for the central chapter, Modes of literary impressionism, where the analytic approach is threefold. Firstly, I venture into the minefield of ut pictura poesis with the hypothesis according to which Helena Westermarck's I89o short story Aftonstämning (Evening Mood) can be seen as a case of literary transposition of a subject and the techniques of impressionist painting. To avoid the mines constituted by loose interart analogies - «suggestive at best but at worst misleading» (Matz 200I: 46) - I test the idea of the «ekphrastic model» developed by Tamar Yacobi (I995 and I998) and study Westermarck's imagistic approach to description with the help of Hans Lund's concept of «iconic projection» (Lund I982: 53). Secondly, as I move on to analyze impressionist traits in Stella Kleve's prose, I explain the specificities of her narrative technique by resorting to Herman Bang's, Sven Møller Kristensen's, Ian Watt's, and Ford Madox Ford's theorizations of the substantial features of literary impressionism. Lastly, I depart from the results stemming from the critical survey applied to the FinlandSwedish press in order to evaluate the nature of Georg Nordensvan's and Mikael Lybeck's texts, which by their contemporary critics were held to be representative of literary impressionism.

When turning to the representation of the impressionist in fiction I have attempted to disclose themes common to the genre of the artist novel that are found in the texts under consideration. This broader framework has led to a discussion of how some of the strategies specific to the genre (see, e.g., Bowie I950: 5-7) are incorporated into the discourse on the impressionist painter. Concentration is on the presentation of the technical and aesthetic discourse of impressionist painting and on the painter's milieu (both the physical environment, inside or outside the city, and the studio, as well as the social setting, such as the painter's circle of friends). The specificities of each text lend themselves to separate discussions: I relate Gustaf af Geijerstam's short story Utan pängar (Moneyless) to Marianna Torgovnick's theorization of the use of the visual arts in fiction (Torgovnick 1985) and discuss the function of ekphrasis in this tale, while the understanding of Georg Nordensvan's Aja seems to benefit from a comparison with the writer's activity as an art critic, and K.A. Tavststjerna's Impressionisten from what seems to be its relationship to phenomenological apperception.

\section{KEY COMPONENTS}

The attempt to unfold the dimensions of literary impressionism within the Swedish cultural context and in the age of impressionism is, similarly, a procedure in three steps: step one conveys the range of the understanding of the phenomenon; step two illustrates the variety of literary impression- 
ism through textual analysis; step three shows the writers' awareness of impressionism by examining fictional impressionists featuring in their texts.

In Part I, Literary impressionism. A variety of concerns, I begin by attempting to explain and reveal studies on literary impressionism that have seen the light after the publication of the Swedish scholar Hans Lund's monograph, Impressionism och litterär text (Lund I993), dedicated to the history and understanding of literary impressionism in an international context, including the Scandinavian scene. To target the subject of investigation, I have tried to map the recent revitalization of the debate on literary impressionism that has taken place above all in France and in the English-speaking cultural context, which Virginie Pouzet-Duzer has spoken of as a «un sursaut d'intérêt» (2013: IO; «a surge of interest») and Max Saunders as a «rehabilitation» (2008c). In the scrutiny of the Scandinavian debate, I depart from recent essays on literary impressionism left untouched by Lund's examination and from handbook definitions of the term, before working my way back in time towards the age of pictorial impressionism, which, as we have seen, offers the temporal limit to the present study.

The three landmark discussions in the history of literary impressionism in the Nordic countries that occurred in the impressionist era offer the background for my own critical survey of the use of term in the Finland-Swedish area. The Danish author Herman Bang's poetics of impressionism, the understanding of impressionism in Hans Jæger's and Christian Krohg's Norwegian review Impressionisten and, in Sweden, August Strindberg's association with impressionism, are firstly scrutinized in depth. These three high-water marks in the Scandinavian debate will, I hope, shine a light on the extensive use of the term in Scandinavia, and, by doing so, on facets of literary impressionism to which the international discussion is perhaps to a certain extent unaccustomed. While Herman Bang's understanding of impressionism engaged with the theatre stage, the intransigence and rebelliousness originally connected with the impressionist movement instead emerge through the Norwegians' and through Strindberg's engagement with impressionism. Moreover, the example of Jæger and Krohg also shows that impressionism was seen as a subjective, autobiographical superseder of naturalism, while Strindberg's reception of impressionist art in 1876 indicates that it was possible to fully understand and admire the unruliness and the 'madness' of the first impressionist painters but, at the same time, disapprove of their technique.

The key issue addressed in this section is, however, a survey of the use of the term in literary criticism written in Swedish in the years I870-I9Io. The examination of the Finland-Swedish newspapers and the periodical Finsk tidskrift is first-hand research and has been undertaken with the aim of finding out to what extent the critics contributing with literary reviews to the Finland-Swedish press proved to be concerned with this category, how it 
was understood and what works and authors were thought to be representative of this phenomenon.

My chief concern in Part II, Modes of literary impressionism. Textual analyses, is to illustrate modes of literary impressionism - some of which partly identified in the preceding section of this study - through examples from works of prose written in Swedish around the turn of the nineteenth century. The models of exemplification have been selected to show the understanding of literary impressionism as a prose departing from the principles of impressionist painting, firstly, and, secondly, to point out the narrative modes characteristic of literary impressionism. In the first case, I use the Finnish painter, critic, and writer Helena Westermarck's (1857-I938) short story Aftonstämning as a springboard for the investigation of the concept and practice of ekphrasis in general, and in the context of impressionism in particular. The interpretation of literary impressionism as a transpositional prose adopting the compositional aesthetics of its painterly counterpart concerns here, I argue, both the motif (the balcony view of a Parisian street) and the narrative technique in the short story. To justify the appropriateness of a comparison and avoid irrelevant and inconsistent speculation, I look at narrative methods such as the use of point of view, iconic projection, framing and cropping. Concomitantly, reading Westermarck's story through the lens of impressionism does reveal the author's strategy of adopting a very modern form to explore social divisions in the Parisian cityscape. The short story is thus seen to constitute a writerly parallel to the 'middle way' found in the Scandinavian painters of the time. The discussion concludes by exposing the tensions between content and form in Westermarck's interart transposition of visual elements, which contradicts the impressionist project to convey only sensory impressions, not ethical or social interest.

As to the second analysis in Part II, I address the multifarious narrative expressions of literary impressionism as they appear in Stella Kleve's short stories and in her debut novel, Berta Funcke. I discuss qualities and narrative methods in her texts seemingly dependent on Herman Bang's impressionism that drew on the principles of theatrical representation, as well as textual features such as the 'metonymic' mode and 'delayed decoding', identified, in the international body of commentary regarding literary impressionism, as characteristic of impressionist prose. Through this second analysis, I wish to show the ways in which Kleve adhered to the impressionist 'school' of writers, in which she, in retrospective, stated to have had a place in the I880s.

Lastly, I examine the grounds for the contemporary literary critics' definition of Georg Nordensvan's short story collection Skuggspel (Shadowplay) and Mikael Lybeck's novels Allas vår Margit (Our Dear Margit) and Den starkare (The Stronger) as examples of literary impressionism.

Within Part III, Fictional impressionists, I bring into discussion the inclu- 
sion of impressionist characters into works of fiction written in Swedish. This chapter does not draw on the writers' ambition to adapt to language the aesthetic theories or the techniques of impressionist painting. Instead, the examination of the impressionist painters that we encounter in Swedish fiction of the late nineteenth century has been undertaken with the aim of adding a piece to the mosaic having as its theme the writers' awareness of, and interest in, impressionism.

One of the ways in which the writers displayed their views and understanding of the methods and aims of impressionist painting may be clarified through a look at their treatment of the impressionist as a literary character. What is the role of the impressionist in these stories? How is the technical and aesthetic discourse presented? This field of investigation is particularly interesting when attention is given to doubly talented authors. Apart from their activity as novelists and short story writers, Gustaf af Geijerstam and Georg Nordensvan were also active as art critics, which is of relevance to the discourse as it implies that they had both the interest and the knowledge necessary to judge and interpret trends in painting.

Not the artistic discourse but the act of perception is instead essential to K.A. Tavaststjerna's tale Impressionisten (The Impressionist). Marck, the protagonist in this short story, is not a fictional painter but a person possessing a particularly sensitive nervous system. In fact, at the thematic centre of this novella is the character's ability to see, i.e., to interpret experience correctly. The protagonist gains reliable data from his subjective impressions and interprets reality merely through his refined senses. My discussion of the text departs from the idea that the presentation of Tavaststjerna's protagonist in the short story features insightful information to access yet another denotation of impressionism, namely the one that defines impressionism as deriving knowledge from sense impressions. Here, it is the impression, not intellectual reflection, that becomes a form of clairvoyance in its own right.

This book builds on a doctoral dissertation completed at the University of Milan. Sections 5 (Part I) and 2 (Part II) are slightly revised versions of articles that originally appeared in Scandinavian Studies and Scandinavica, respectively (Storskog 2011 and 2012). 



\section{PART I}

LITERARY IMPRESSIONISM.

A VARIETY OF CONCERNS 



\section{I.}

\section{WHAT IS IN A WORD?}

«What exactly is meant by 'impressionism' in fiction?» is one of the questions raised by Marianna Torgovnick in a scathing commentary on Mario Praz's concluding words to his essay Mnemosyne: the Parallel between Literature and the Visual Arts (Torgovnick 1985: 6). With this, and a host of other queries, Torgovnick is phrasing her perplexity when confronted with Praz's view on interart analogies relying on the idea of a vague and general Zeitgeist. Torgovnick's wording is only apparently simple: the adverb «exactly» and the single quotation marks enveloping the noun «'impressionism'» are bound to generate a series of reflections within a context like ours, discussing the history, the existence and the usefulness of the term literary impressionism.

I will begin this section of the present work by looking at interpretations of literary impressionism in publications that have recently appeared in the French and in the English-speaking cultural contexts, areas which currently appear to be the most fertile ground for studies dedicated to impressionist literary writing. I will then go on to discuss the few contributions to the debate on literary impressionism that have surfaced in Scandinavia in the years succeeding Hans Lund's publication Impressionism och litterär text in 1993. To complete the discussion of contemporary interpretations of the notion, I will, in addition, consider handbook definitions of literary impressionism in different cultural contexts, in an attempt to discover how the concept is defined in some of the language areas that recognize it as a literary tendency. Next, I will turn my attention to three key moments in the Scandinavian history of literature of relevance to our discussion here: Herman Bang's authorship, the Norwegian review Impressionisten, and August Strindberg's association with impressionism all constitute highlights in the late nineteenth-century Scandinavian debate on impressionism and literature and will therefore be deeper delved into in the following paragraphs.

The survey of the use of the term in this chapter will end with a profound 
investigation of its application in the literary criticism written in Swedish and present in the Finland-Swedish newspapers, as well as in the review Finsk tidskrift, in the years I880-I900, approximately. This last attempt to outline the attention given to the concept by literary critics is first-hand research, made possible through the electronically accessible digital archives of the Finnish Historical Newspaper Library. The results stemming from this survey have allowed me to identify authors, texts, and stylistic modes connected with the idea of literary impressionism - in the impressionist era and in a Swedish and Finland-Swedish cultural context - this investigation therefore, directly or indirectly, lays the basis for the selection of texts analyzed in the third chapter of this study.

If «the recent rehabilitation of the concept of literary impressionism», of which Max Saunders has spoken in his entry on literary impressionists in the Oxford Dictionary of National Biography (Saunders 2008c) ${ }^{\mathrm{I}}$ - a rehabilitation to which the present study aims to contribute - is persistently proving the pointlessness in earlier incitements (or provocations) to drop the term «from the [...] literary vocabulary» (Brown I968: 59), time has come to permanently unwrap the single quotation marks, which, in Torgovnick's query, parcel up impressionism as a 'foreign' word to literature, and resign to the fact that 'exact' is an adjective that hardly applies to its definitions ${ }^{2}$. To paraphrase Wylie Sypher, who, on the subject of the impressionist painters, claims that «they have no method - only methods» (Sypher I960: 170), this first chapter of my study will set the scene for my belief that there is no mode of literary impressionism - only modes.

What, then, approximately, is literary impressionism?

I http://www.oxforddnb.com/view/theme/96337. Accessed 7 February 2018.

2 By contrast, Florence Dumora, in her essay L'Impressionnisme entre guillemets (Impressionism in Quotation Marks), discusses various meanings of the use of quotation marks in combination with the term literary impressionism, and comes to the conclusion that the «guillemets d'approximation» (2012: 35, italics in the original; «quotation marks indicating approximation») are to be employed when referring to this category of writing. She states: «ces guillemets sont là pour rappeler l'impropre, qui signifie autant ce qui n'est pas approprié que ce qui est figuré sans propre identifiable» (Ibidem, italics in the original, «these quotation marks are there to remind us of the inappropriateness, by which is meant both what is not appropriate and what is figured without precise identification»). 


\section{REVIEW OF PREVIOUS RESEARCH}

The most complete overview of how the concept of literary impressionism has been used, internationally, in literary criticism and in the writing of the history of literature is to be found in the Swedish scholar Hans Lund's study, Impressionism och litterär text (I993; Impressionism and Literary Text). To the scholar interested in the history and the evolution of this notion, Lund's work is of immense value, as it examines the use of the term during the eleven decades following its coinage in I879. Three chapters of his book (Lund I993: 25-I03) chronologically analyze the understanding of literary impressionism within four cultural fields: the French, the English-speaking, the German, and the Scandinavian. An additional chapter (1993: 105-59) explores four widespread interpretations of literary impressionism retrieved in the international debate on the theme: (I) impressionism as a literary style expressing itself through grammar and syntax; (2) as literary writing emanating from its painterly equivalent; (3) as a matter of perception and phenomenological concerns; (4) as a term employed both ahistorically and limitedly within a clear-cut period in the history of literature. Lund's study is thus a matchless exposé of the global history of this critical notion, focussing on how different language areas have repeatedly charged the term with mutable substance in the course of the twentieth century. The importance of his work also lies in incorporating, for the first time, the Scandinavian perspective into the more than centenarian transnational discussion regarding impressionism and literature. It is therefore unfortunate that Lund's achievement should not have reached a broader readership through translations.

As a source of information on the critical fortune of the term 'literary impressionism', Lund's work is comprehensive and its value cannot be overestimated. My discussion of the state of scholarly research revolving around impressionism in literature therefore concentrates on the latest research output that has emerged in the years left untouched by Lund's examination and 
will, when necessary and only briefly, assess previous definitions of literary impressionism with reference to the results stemming from Lund's seminal investigation. During the more than twenty years that have followed the publication of Impressionism och litterär text, several new studies on the subject have come to light, so much so that the British scholar Max Saunders (2008c) has highlighted, as mentioned earlier, the ongoing renaissance of scholarly interest in this category and welcomed the revitalization of a critical notion that, in his view, helps to «explain the transition from late nineteenth-century realist or aesthetic writing to early twentieth-century modernism $»^{\text {. }}$.

\section{I. FRENCH LITERATURE}

Though none of the recent publications that will be discussed in the following pages has adopted Hans Lund's broad and historical perspective, it is noteworthy that in France, where the painterly counterpart to literary impressionism first appeared and where the term was coined, in I879, by Ferdinand Brunetière - in French and on the subject of a French novel ${ }^{2}$ - the coinage «impressionnisme littéraire» has reverberated but intermittently until recent years. In the words of Virginie Pouzet-Duzer, author of a doctoral thesis entitled L'Impressionnisme littéraire: capture de l'insaisissable (2008; Literary Impressionism: Capturing the Unattainable)": «'Literary impressionism' du champ anglo-saxon, 'Impressionismus' allemand n'ont pas, dans les manuels littéraires scolaires et universitaires actuels, d'équivalent français» (Pouzet-Duzer 2008: 2; «the English-language 'Literary impressionism', the German 'Impressionismus', do not have a French equivalent in contemporary handbooks of literature for schools and universities»)4.

I http://www.oxforddnb.com/view/theme/96337. Accessed I8 May 2013.

2 Ferdinand Brunetière (1879) first used his own coinage «impressionnisme littéraire» to describe Alphonse Daudet's I879 novel Les Rois en exil (Kings in Exile).

3 The dissertation was published in a slightly different version with the title L'Impressionnisme littéraire in 2013 (Pouzet-Duzer 20I3).

4 In his scrutiny of the history of literary impressionism as used by French scholars, Lund observes that in the early i 88 os, Jules Lemaître, as well as Louis Desprez, picked up this notion to define the style of the Goncourt brothers, a line subsequently continued by Pierre Sabatier in the I920s. In this decade Charles Bally also published his study Impressionnisme et grammaire (Impressionism and Grammar), exploring the stylistic and grammatical specificities of literary impressionism (Bally I920), cf., Lund I993: 25-29. In I952, two publications dealing with impressionism and French literature appeared: Ruth Moser's L'Impressionnisme français: peinture, littérature, musique (Moser 1952), and Helmut Hatzfeld's Literature through Art. A New Approach to French Literature (Hatzfeld I952). Both authors tie the idea of literary impressionism to Paul Verlaine and, according to Lund, «ser impressionismen som en epokal stil kring sekelskiftet I900. Båda anför vissa stilistiska drag som typiska: erlebte Rede, substantiverade adjektiv, korta meningar, pars pro toto» (I993: 7I; «look at impressionism as the style of an epoch, i.e., the fin de siècle. Both claim certain stylistic traits to be typical: free indirect speech, the nominal use of adjectives, short phrases, pars pro toto»), especially Hatzfeld, Lund adds, «mottogs med tvekan» (7I; «was received with reservation»). René Marill Albérès is, according to Lund (I993: 
In her own attempt to get to the substance of literary impressionism, Pouzet-Duzer falls back on the tradition that has stressed the vagueness of the term as she sets out by underlining its fleetingness in the very title of her doctoral thesis, introducing what she calls «cette étrange catégorie stylistique» (Pouzet-Duzer 2008: 3; «this curious stylistic category») as «un art de la fuite, une manière stylistique de résister justement aux catégories» (2008: 2; «an art of escape, a style shunning categories»). She also claims that the perfect impressionist writer is nowhere to be found as he is but «une fiction critique, [...] une création idéalisée» (2008: 2; «a fiction of the critics, [...] an idealized creation»). When outlining her methodology, Pouzet-Duzer indicates the 'German' approach to literary impressionism as her initial point of departure (2008: 6-7): in an early stage her project wished to trace, with the help of modern information technology, the impressionist character of French literary prose in the wake of the German scholar Luise Thon's theory of an impressionist grammar based on asyndeta, omission of verbs, uncommon positioning of adjectives denoting colour, etc 5 . This strategy was subsequently abandoned because the results were

92), one of the few French scholars to have demonstrated an interest in literary impressionism in the second half of the twentieth century. His research, carried out in the Ig6os, deals, on the one hand, with English-language authors such as Joseph Conrad, Henry James, Katharine Mansfield, and Virginia Woolf and, on the other, with the French nouveau roman through a phenomenological approach with no connection to Brunetière's idea of literary impressionism's close relationship to its painterly counterpart, cf., Lund I993: 79. A small monographic study dedicated to Mallarmé's impressionism, apparently unknown both to Lund and to PouzetDuzer, was published in Italy in the I950s, Luigi De Nardis's Impressionismo di Mallarmé (De Nardis I957). Enzo Caramaschi instead deals with Balzac's impressionist landscapes in a study from I985 (Caramaschi I985), and Kronegger (I973b) discusses authors ranging from Flaubert to Sartre. A discordant voice against the general background offered by Lund, and also against Pouzet-Duzer's opinion on the French situation, is represented by Bernard Vouilloux, who, although not unaware of the term as a fleeting and problematic category, has recently spoken of literary impressionism's «longue et féconde carrière dans le champs de la critique littéraire, des histoires de la literature et de la langue françaises, ainsi que dans le domaine des études stylistiques et même linguistiques» (Vouilloux 20I2b: I; «long and fertile career in the field of literary criticism, in histories of French literature and language, just as in the area of stylistic and even linguistic scholarly work»), quoting the examples of Gilles Philippe and Julien Piat's La Langue littéraire. Une historie de la prose en France de Gustave Flaubert à Claude Simon (The Literary Language. A History of French Prose from Gustave Flaubert to Claude Simon) from 2009, and Louis Petit de Julleville's Histoire de la language et de la literature française des origines à 1900 (A History of the French Language and Literature from their Origins to 1900) from I899, both containing chapters on impressionist language and literature.

5 In 1928, Luise Thon published the study Die Sprache des deutschen Impressionismus (Thon I928; The Language of German Impressionism), which came to set the scene for Sven Møller Kristensen's scrutinity of Danish literary impressionism in I955. Thon determined the impressionist character of the prose of authors such as Johannes Schlaf, Stefan George, Gerhardt Hauptmann, Hugo von Hoffmannsthal, Arno Holz, Detlev von Liliencron, Thomas Mann, Conrad Ferdinand Meyer, Rainer Maria Rilke, and Arthur Schnitzler, on the basis of linguistic, grammatical, and stylistic elements (parataxis, polysyndeton, nominal phrases, etc.) present in their texts. This approach, thus based on formal, linguistic investigation, is representative of the understanding of literary impressionism flourishing among German scholars in the I920s (Loesch I9I9, Richter I927, Wenzel I928). These studies mark their distance from the earlier 
not judged to be scientifically objective (2008: 7). In its final version, the methodology at work in L'Impressionnisme littéraire: capture de l'insaisissable, Pouzet-Duzer acknowledges (2008: 13), draws on and attempts to surmount the two opposite approaches to literary impressionism revitalized in the current French debate on the subject. On the one hand, in an essay entitled L'Impressionnisme littéraire: une révision, Bernard Vouilloux has problematized the stylistic peculiarities of literary impressionism, advocating a return to the study of syntax and grammar in order to get to the heart of the phenomenon (Vouilloux 2000). On the other, Richard Berrong, in his article Modes of Literary Impressionism, and in the book Putting Monet \& Rembrandt into Words, has instead attempted to re-establish the ancient connection between literary impressionism and the aesthetics of impressionist painting on the subject of the French writer Pierre Loti (Berrong 2006 and 2013) ${ }^{6}$.

Consequently, Pouzet-Duzer is approaching her subject both as a writing dependent upon the impressionism of the painters (the relationships between impressionist painters and writers being, in her words, the «condition sine qua non» [2008: I8] for the existence of literary impressionism) and as a literary style. Through the juxtaposition of paintings and texts, the attempt is to prove that writers and painters such as Édouard Manet, Zacharie Astruc, Émile Zola, Stéphane Mallarmé, Edgar Degas, and Paul Valéry, were guided by the same cognitive concepts and principles of representation. Through close readings, the author then proceeds to determine how these relationships influenced, in particular, the writing of the Goncourt brothers and Alphonse Daudet, whose style is compared to those of their contemporaries. Having established that the fragment is the ultimate expression of impressionist literature, the study concludes by examining representations of scenes of Parisian city life in words and images.

Given the number of recent critical contributions, Vouilloux (2000; 20I2a; 20I2b), Berrong (20I3 and 2006), Pouzet-Duzer (2008 and 20I3),

use of the term in Germany and in Austria where, from the late nineteenth century onwards, Impressionismus or Eindruckskunst had been synonymous with the opposition to naturalism in the view of several authors, for example Hermann Bahr (1894). In the German thirties the term carried a stigma, and because of its connection to French decadentism it was seen in opposition to 'true' German values, cf., Lund I993: 36-45. More recently, Hartmut Marhold has taken up the issue of literary impressionism's relationship to German poetry, see Marhold I985 and I99I. In a recent article entitled L'Impressionnisme et la littérature allemande. Les modalités d'un double transfert culturel (Impressionism and German Literature. The Modes of a Double Cultural Transfer), Beate Langenbruch discusses Austrian and German literary impressionism in relation to their French counterpart. She also gives a concise overview of late twentieth-century studies dedicated to the specifities of the phenomenon in the German-speaking literary context, see Langenbruch 20I2: I07, note 6 . According to this list, no major study of German literary impressionism seems to have emerged in recent years.

6 It should be added that Berrong (2013: 23-24) has chosen not to employ the terms 'impressionist literature' and 'literary impressionism' in his study so as not to add to what he sees as a conceptual «confusion». Instead, he discusses specifically «Loti's success in recreating Monet's type of Impressionism» (35). 
to which a conference on the subject Impressionnisme et littérature held in Normandie in 2010 should be added7, Virginie Pouzet-Duzer's deduction that we are currently going through a phase of renewed interest in the critical province of literary impressionism seems applicable also to a French perspective $^{8}$.

\subsection{THE ENGLISH-LANGUAGE CONTEXT}

A milestone in the history of the critical notion of literary impressionism within the English-language context was the Symposium on Literary Impressionism held at Indiana University, Bloomington, in I968. Although there are voices in the conference proceedings (Remak and Weisstein I968) 9 indicating a wish to do away with a term causing «nothing but confusion» (Brown I968: 59), in the following thirty years a great number of publications in the English-speaking world have challenged Brown's request for reticence as to discussing impressionism in literature. In 2008, for example, Max Saunders (2008a: 158 ) would claim that «there has been a noticeable return to the idea of literary Impressionism in some of the best recent studies of literary history and theory» ${ }^{\mathrm{IO}}$.

In the early I990s, where Lund's investigation ends, the discussion continued with shorter contributions by Adriaan De Lange (1992), Suzanne Ferguson (I994) and Brian May (I994), and was unquestionably relaunched at the beginning of the new millennium by studies, often in the form of

7 The conference, arranged by the Centre d'étude et de recherche Éditer-Interpreter (CEREDI), was held in Rouen, 9-II June 20I0. The proceedings of the conference were published in 2012 in a volume edited by Gérard Gengembre, Yvan Leclerc, and Florence Naugrette, entitled Impressionnisme et littérature (Gengembre, Leclerc and Naugrette 20I2). The essays present in this work deal, on the one hand, with the relationships between painters and writers and, on the other, with literary impressionism in terms of «un mythe, un malentendu, ou une réalité» (Rubin 2012: 7; «a myth, a misunderstanding, or a reality»).

8 Pouzet-Duzer speaks of «un sursaut d'intérêt pour cette thématique outre Atlantique» (2013: I0; «a surge of interest for this theme in America»), characterizing the early twenty-first century.

9 Also available at https://archive.org/details/yearbookofcomparoI7776mbp. Accessed 7 February 20I8. Pages 69-72 of the proceedings from the Symposium are a bibliographical compilation of critical writings concerned with literary impressionism.

IO Some, but not all, of the following English-language publications are briefly discussed by Lund (1993: 98-102): Kronegger 1973a, Armstrong 1976 and 1987, Ferguson 1979, Nagel I980, Stowell I980, Kirschke I98I, Schnitzer I988, Van Gunsteren I990. As Lund observes (I993: I02), the writers generally considered evocative of English literary impressionism are Henry James, Stephen Crane, Joseph Conrad, Ford Madox Ford, Virginia Woolf, and Katherine Mansfield. The aforementioned scholars concentrate on the act of perception and on the relationship to the visual arts in their interpretation of literary impressionism and, unlike the German scene, few researchers operating in the English-language cultural context investigate the possibility of an impressionist language and grammar, with the exception of Todd $\mathrm{K}$. Bender and Sue M. Briggum's survey Quantitive Stylistic Analysis of Impressionist Style in Joseph Conrad and Ford Madox Ford (Bender and Briggum 1982). 
monographs - and often rejecting the presumption that literary impressionism needs to be definied as patterned after impressionist painting by Tamar Katz (2000), Robin Hoople (2000), Jesse Matz (200I and 20I2), John G. Peters (200I) and, more recently, Melissa C. Reimer (2009; 20I0 and 20II), Max Saunders (2004a; 2004b; 2005; 2005a; 2008a; 2008b; 2OII and 20I3), Young Sun Choi (20II), Adam Parkes (20II), and Rebecca Bowler (2016).

Katz inserts literary impressionism into the modernist movement and uses the term to explain female subjectivity in modernist novels; Hoople describes the hostility encountered in many of the early American reactions to the prose of Henry James as an incapacity to grasp the idea of literary impressionism; finding it «suggestive at best but at worst misleading», Jesse Matz (200I: 46) looks with suspicion upon the results of interart comparison that has occupied much scholarly work on impressionist fiction and attempts to remap literary impressionism by stressing the latter part of the term thus tracing - through Walter Pater, Henry James, Thomas Hardy, Joseph Conrad, Ford Madox Ford, and Virgina Woolf - the aesthetics of the 'impression' back to the philosophy of John Locke and David Hume. In his discussion of Joseph Conrad's impressionism, Peters, too, does away with literary impressionism's traditional connection to the visual arts, basing his personal definition both on narrative techniques and on philosophical and socio-political groundings.

From a more customary cross-disciplinary perspective, Reimer has worked extensively on Katherine Mansfield's writings in relation to impressionist and post-impressionist painters. Two of her articles (Reimer 2009 and 20II) examine the allegiance to impressionism in the pictorial qualities of Mansfield's work, indicating possible painterly sources. In her doctoral dissertation (Reimer 20I0), Reimer further explores the style and technique with which Mansfield treated three of her dominant subjects - domestic interiors, urban landscapes, and rural scenery - and compares this treatment to that of those impressionist painters who cherished the same subjects. The characteristics held up for comparison include Mansfield's manner of conveying overall impressions, her use of grammatical categories «for impressionistic purposes» (Reimer 2010: 52); her swift moves between characters and from scene to scene without authorial intervention; her own references to impressionist paintings.

Interart analogies are also at play in Choi's study, where Katherine Mansfield's art is again scrutinized with reference to the aesthetics, techniques, and themes of the impressionists. In a bid to study the interaction between texts and contexts, Parkes, instead, connects the aesthetics of the impressionist language and literary style in the writings of authors such as Walter Pater, Joseph Conrad, and Virginia Woolf, to historical forces present in the period from the I870s to the I930s: sexual politics, anar- 
chism, terrorism, feminism. Rebecca Bowler studies the impressionism of Dorothy Richardson and H.D. and May Sinclair, writers generally absent in discussions on literary impressionism, and reads their texts in the light of Ford Madox Ford's impressionist dictums, also engaging with the writers' attempts to employ cinematic styles.

Max Saunders has worked extensively on literary impressionism and its relation to modernism through the examination of Ford Madox Ford's authorship (Saunders 2004a; 2004b; 2005a; 2008a; 2008b; 20II and 2013). He is also the author of entries on literary impressionism in the Oxford Dictionary of National Biography (Saunders 2008c) and in A Companion to Modernist Literature and Culture (Saunders 2005), in with he explains literary impressionism as «a category that can help explain the transition from late nineteenth-century Realist or Aesthetic writing to early twentieth-century Modernism» (2008c).

\subsection{SCANDINAVIA}

Before the publication of Lund's work, research on Scandinavian literary impressionism either focussed on individual authorships such as Herman Bang's (Nilsson I965), Cora Sandel's (Rykkja I976), and Jonas Lie's (Gustafson I940: 25-72), or concentrated on literary impressionism predominantly as a phenomenon regarding style (Dahl I98I: 68-93) or rhetoric and grammar (Møller Kristensen I955). Among the contributions - not mentioned by Lund - to the critical debate on literary impressionism in Scandinavia, is Pil Dahlerup's article Impressionismen - 'En Unatur, som dog findes i Naturen' (Impressionism - 'an Unnatural Aspect of Nature'), focussing on Mathilda Malling and J.P. Jacobsen (Dahlerup I987), as well as Christine Pullwer's unpublished M.A. thesis investigating impressionist tendencies in Christian Krohg's novel Albertine and in his homonymous painting (Pullwer I99I).

The first decade of the new millennium saw the publication of an essay by Dag Heede entitled Herman Bang og seksualiseringen aflitteraturhistorien. Eller: er impressionismen en homoseksuel fortcelleteknik? (Heede 2003; Herman Bang and the Sexualization of Literary History. Or: is Impressionism a Homosexual Narrative Technique? $)^{\text {II. }}$ Published a few years earlier, Birgitta Ney's Bortom berättelserna: Stella Kleve - Mathilda Malling (Beyond the Stories: Stella Kleve - Mathilda Malling) contains a section on impressionism and the prose of this Swedish novelist and short story writer (I993: I35-6I) and the scholar returns to the issue in 2005, in a short essay entitled Impressionism och modernitet hos Stella Kleve (2005; Impressionism and Modernity in Stella Kleve).

II Heede's essay will be discussed in the section of the present work dedicated to scholarly views on Herman Bang's impressionism, see 4.I.I. 
Axel Lindén's doctoral dissertation dedicated to Herman Bang, Förnimmelser: en fenomenologisk analys av Herman Bangs författarskap (2009; Perceptions: a Phenomenological Analysis of Herman Bang's Authorship), touches the question of the Danish author's impressionism marginally in the analysis of the act of perception in his novels. In addition, Simon Stensson Johansson's unpublished M.A. thesis, examining impressionist stylistic devices in the 1906 poetry collection Skyarne (The Clouds) by the Swedish poet Ivar Conradson (Johansson 20II), is available online for consultation ${ }^{12}$.

Before concentrating on individual, subjective, decodings of literary impressionism in Bang, the review Impressionisten, and Strindberg, all central to the definition of the notion in Scandinavia, I will briefly trace handbook explanations of the concept in an attempt to gather the wide array of definitions into a concise and unified overview.

I2 Available at https://gupea.ub.gu.se/handle/2077/279I9?locale=sv. Accessed 7 February 2018. 


\section{$3 \cdot$ \\ LITERARY IMPRESSIONISM: THE HANDBOOK DEFINITIONS}

In The Cambridge History of French Literature, Robert Lethbridge departs from Brunetière's early codification of the analogies between impressionist painting and literary techniques to explain literary impressionism. Drawing parallels between themes and subjects in painting and in «the work of the majority of the novelists» (Lethbridge 20II: 534) in the age of impressionism ${ }^{\mathrm{I}}$, he suggests that painters and novelists alike were occupied with motifs such as:

stations, steam-engines and railways; the suburbs; river settings west of the capital; scenes from peasant or working-class life; laundresses; cafés and carriages; absinthe drinkers; strolling Parisian crowds; markets and shops; prostitutes and brothels. There are also analogies of perspective in innumerable panoramic views from windows, balconies, or other elevated sights $[\ldots]$ overlooking the bustle of the modern cities. And so precise are the correlations of descriptive fabric, with a similar emphasis on the unfocused and the play of light and shade at different times of day according to the weather, that temptations of transpositional identification are hard to resist. (Ibidem)

The limits of interart analogy are, however, also taken into consideration by Lethbridge, who comments that the act of reading, necessarily se-

I In particular, between Manet's painting Nana from 1877 and Zola's L'Assommoir, published in 1876 , between Monet's and Pissarro's serial paintings and Zola's 1878 novel Une Page d'amour (A Love Episode) and, in general, between the writings of Flaubert, Daudet, the Goncourt brothers, and Maupassant, and painting of the contemporary age (Lethbridge 53435). According to Lethbridge: "even when this is no more than coincidence in terms of detail, such intersections point to a newly expanded focus on the prosaic texture of the modern world and new ways of seeing it" (535). 
quential, is by nature «at odds with the illusion of undirected optical experience available to the painter» (535). He then suggests that a more valid correspondence to the «optical experience» (537) and the evanescence of the painters is better found in the genre of poetry, indicating the examples of Mallarmé and Rimbaud, because of the «essentially non-referential qualities of [their] poetic language» (Ibidem).

Ignoring Brunetière's coinage, the French Dictionnaire historique, thématique et technique des littératures. Littératures française et étrangères, anciennes et modernes (Demougin I985) describes literary impressionism as a tendency that

cherche à capter la réalité dans ce qu'elle a de plus fugitif [...] ce qui compte, ce n'est plus la description ni l'action extérieure, ce sont le sensations, les sentiments, les états d'âme, les impressions. Il aime les formes brèves (poèmes, esquisses, aphorismes, pièces en une acte, courts récits); il mélange volontiers les genres et disloque le vers, la strophe, la phrase pour mieux cerner la sensation éphémère et unique. Ses héros sont des êtres ultrasensibles, passifs, souvent maladifs, enregistrant tels des sismographes (grâce au monologue intérieur) les moindres tressaillements de leur âme [...]. (Demougin I985: 755)

attempts to capture the most fugitive aspects of reality [...] what counts is no longer either description or external action but sensations, feelings, states of mind, impressions. It favours short forms (poems, sketches, aphorisms, one-act dramas, shorter tales); it willingly mixes genres and dislocates lines, verses, and phrases, to better define ephemeral and unique sensations. Its heroes are hypersensitive, passive, sickly, registering in the manner of seismographs (thanks to interior monologues) the slightest movements of their souls [...].

While this French dictionary indicates the Austrian Jung Wien school as the foremost representative of literary impressionism, reducing impressionism in French writing to an inclination of literary criticism «dans laquelle prevalent l'intuition et la sensibilité de l'analyste» (755; «in which the intuition and the sensibility of the analyst prevail»), it is remarkable that a Spanish dictionary of literary terms should, on the contrary, indicate precisely France as the home of literary impressionism, and the French writers Paul Bourget and Maurice Barrès as «los primeros escritores a los que se ha asociado a esta corriente» (Estébanez Calderón 2004: 559; «the first writers to be associated with this current»). On the subject of Jung Wien, in The Cambridge History of German Literature, Ritchie Robertson (1997: 348) also departs from Hermann 
Bahr's essay to illustrate the heartfelt need within the Viennese circle of intellectuals to «abandon the Naturalistic fictions of a knowable external reality and a continuous self, and focus instead on the sensations and impressions of which consciousness was composed». Peter Altenberg's sketches of Viennese life, with their attempt to «convey atmosphere through colour and sound» (Robertson I997: 348) and the use of «unorthodox punctuation to suggest unspoken emotional nuances» (348) are presented as «a verbal counterpart to artistic Impressionism» (348), though Richard Beer-Hofmann's I9oo novel Der Tod Georgs (The Death of Georg) is, according to Robertson, «the finest piece of Impressionist prose» in the literature written in German.

In J.A. Cuddon's A Dictionary of Literary Terms and Literary Theory, the terms «impressionist» and «impressionism» are said to «have crept into literary criticism» although «they are vague terms which we might well dispense with» (Cuddon I99I: 446). As examples of writers connected with literary impressionism, Cuddon cites the French symbolist poets, as well as Oscar Wilde and Arthur Symons, and also states that abundant examples of the specifically impressionist technique «of concentrating on the inner life of the main character rather than on external reality» (Ibidem) are to be found in James Joyce, Marcel Proust, Dorothy Richardson, and Virginia Woolf. A Handbook of Literary Terms (Yelland, Easton, and Jones I983) lists works by Katherine Mansfield, Dorothy Richardson, Mary Sinclair, and Virginia Woolf as impressionist, and refers (I983: 90) to their method as one opposed to realism (which «tries to give all the details with the objectivity of a camera») and to expressionism (dealing not with reproduction of external reality but «with inner life»), concerned with selecting «a few details to convey the immediate sense impression left by a scene». An example of this technique is given through a quotation from Woolf's Jacob's Room, where the writer applies a filmic montage-technique consisting of assembling random scenes in no logical order as a way of building up an atmosphere (I983: II4).

Under the entry 'impressionism' in The Oxford Companion to English Literature, we find an account of pictorial impressionism and the (uninspired) concluding comment that «the term is used by transference in literature and music» (Drabble 2000: ${ }^{1}$ 6). The Handbook of Literary Terms. Literature, Language, Theory blandly explains impressionist poetry as one cultivating «reflective emotion and refined rhythm and diction» (as in Arthur Symons) and impressionist novels as pieces of prose exploring «the inner lives of characters rather than the reality they inhabited» (Kennedy, Gioia, and Bauerlein 2009: 82). Merriam-Webster's Encyclopedia of Literature puts the emphasis on a depiction striving to evoke subjective and sensory impressions of a scene rather than the objective reality; writers quoted as impressionists are again Richardson, Woolf, and Joyce, «who employ stream-of-consciousness techniques» (Kuiper I995: 583). Anthony Burgess's entry (Burgess 20I4) on the novel in the Encyclopedia Britannica 
identifies literary impressionism with the early twentieth century's breaking down of narrative conventions such as the omniscient narrator, the rigid space-time continuum, or the eloquence of fictional characters, whose speech is 'edited' by the author. In the prose of Ford Madox Ford, the EB detects «fallible, partially ignorant» character-narrators, a liquidation of «stepby-step temporal progression» and a new approach to articulating dialogues and conversations, all aspects of the style of the impressionist novel ${ }^{2}$.

The art of Ford Madox Ford is central also to the aforementioned Max Saunders's reflection on literary impressionism. Ford, together with Joyce, Conrad, and Stephen Crane, are indicated as «the principal exponents of literary impressionism» in English-language letters, according to Saunders's voice Literary impressionists in the Oxford Dictionary of National Biography (Saunders 2008c). Although Ford, the author of «voluminous writings on the topic» of literary impressionism, is the only one to have «explicitly defined himself as an impressionist», these four writers shared a desire to award «prominence to the fragmentary impressions and memories of intensely visual scenes in the consciousnesses of [...] characters» (Saunders 2008c).

Finally, as to the Scandinavian context, the signature 'LL' in Gyldendals litteraturleksikon from I974, defines impressionism as a late nineteenth-century «modeord for litterære stiltræk [...] som kan findes mere eller mindre hyppigt i lit. til vidt forskellige tider, men som bryder særlig stærkt igennem som konsekvens af og reaktion på naturalismen» ('LL' I90; «buzzword for stylistic characteristics in literary writing [...], which can be more or less frequent in the literature of any age, but which makes a major breakthrough as a consequence and reaction to naturalism»), involving, among other things, the disappearance of the omniscient narrator in the text, the technique of the filmic montage of scenes, the reproduction of real-life, 'un-edited' speech (I90-9I). In Dansk littercer opslagsbog, Poul Zerlang (I985: 63) sees impressionism as one of the two major literary styles connotating Danish prose in the period I870-90. Literary impressionism is here explained as a style reflecting the raw and rationally unorganized sensorial impressions, which are often rendered through vague allusions or metonymic description requiring the readers' collaboration: «den typiske impressionist vil gribe de få, men væsentlige enkeltheder i situationen eller billedet og lade læseren selv udfylde resten» (Ibidem; «the typical impressionist aims at capturing the few, but essential details of situations and pictorial representations and leaves it to the reader to complete the rest»).

In Svenskt litteraturlexikon, Peter Hallberg (I970: 257-59) explains literary impressionism through the painterly analogy and as the writers' completion of naturalism by way of substituting the detailed inventories of naturalist description with the reproduction of «intrycket av pulserande liv» (258; «the

2 http://www.britannica.com/EBchecked/topic/42I07I/novel/50992/Impressionism. Accessed I3 January 2015. 
impression of pulsating life»). Hallberg mentions the Goncourt brothers as forerunners of this stylistic category characterizing the literature of the last decades of the nineteenth century. As to theoretical works on the subject, the author discusses the works of Luise Thon (I928), Sven Møller Kristensen (I938 and I955) and Torbjörn Nilsson (I965), and, quite apparently drawing on Karl-Erik Lundevall's (I953: 238-47) observations on impressionism and Swedish literature, adds: «för svensk litteratur under samma skede finns ingen motsvarande undersökning. Men typiskt impressionistiska inslag kan iakttas i Strindbergs prosa fr. o. m. Röda rummet eller i Heidenstams Vallfart och vandringsår» (258; «there exists no corresponding survey of Swedish literature in the same period. But typical impressionist traits can be observed in Strindberg's prose starting from Röda rummet [The Red Room] or in Heidenstam's Vallfart och vandringsår [Pilgrimages and Wander Years]»).

The interart analogy is, according to Hallberg (here heavily dependent on Kristensen's theorization), visible also in the impressionist writer's rebellion to grammatical syntax:

\begin{abstract}
Om de impressionistiska konstnärerna förkastade teckningen som grundval för måleriet, så kunde författarna å sin sida sätta den traditionella skriftsspråkssyntaxen ur spel [...]. Sålunda bryts ofta den grammatiskt logiska ordföljden för att ge starkare relief åt något drag i verklighetsbilden. Den hypotaktiska satsbyggnaden ersätts i stor utsträckning av en parataktisk. [...] På det hela taget dominerar i syntaxen den associativa principen över den analytiska. Som typiska för i:s strävan till syntetisk gestaltning av sammansatta intryck kan man betrakta visa ordkomposita av mer tillfällig art; "frosttyst" (Ola Hansson), "sommarblanka kvällar" (Heidenstam), "blygtförnäm" (Fröding). (I970: 227)
\end{abstract}

If the impressionist painters disdained drawing as the basis for painting, the writers could, for their part, turn their back on the traditional syntax of the written expression [...]. Correspondingly, the grammatically logical syntax is broken up to clearly highlight a single aspect of the image of reality. Hypotaxis is substituted by parataxis. [...] On the whole, in syntax it is the associative principle that dominates on the analytical one. Composites of an occasional kind, though typical of impressionism's attempt to synthetically render complex impressions, are "frost-silent" (Ola Hansson), "summer-bright evenings" (Heidenstam), "shy-elegant” (Fröding).

Hallberg also mentions the narrator's position and the presentation of speech as details that allow the reader to recognize writers of the impressionist school. In literary impressionism, Hallberg explains, the narrator 
hides his own presence, achieving invisibility through the characters' direct speech and through the presentation of dialogues that do not require authorial intervention but create an illusion of a cascade of lines belonging to different characters:

replikerna kunde komma huller om buller, flimrande, kaotiskt. De behövliga regianvisningarna gavs i korta inskott mellan replikskiftena, referatet inskränktes till ett minimum. Det innebar ett närmande till den dramatiska formen: man skulle uppleva prosafiktionen, som om man bevittnade ett skådespel. (I970: 227)

the lines would be delivered pell-mell, in a flickering chaos. Any necessary instructions were supplied as brief insertions between the dialogues, reports [from the narrator] were reduced to a minimum. This meant drawing closer to the dramatic form: prose fiction was to be experienced as a play.

Again building on Møller Kristensen's studies in literary impressionism, Hallberg reports (Ibidem) that a way of creating a pseudo-objective narration is through indirect description, i.e., through the use of linguistic expressions recognized as typical of the character described, and through free indirect speech or stream-of-consciousness technique.

In summary, the authors' struggle to make the term manageable is evident in most handbook definitions of literary impressionism. However, even short and concise entries of this kind do not fail to stress the impractical vagueness of a term indicating a literary writing aiming to grasp «fugitive aspects» of reality, «ephemeral» sensations, feelings and states of mind; Cuddon, as we have seen, though including it in his dictionary, goes as far as to suggest its uselessness. Difficulties in pinning down the dominant characteristics of literary impressionism might well depend on the specificities the tendency has taken on during its migration between different cultural contexts: while the English-speaking literary culture seems to consider the stream-of-consciousness technique as a fundamental trait of impressionist writing, German experts still define literary impressionism through stylistic and grammatical categories (Gfrereis I999: 89-90), and the Danish critics interpret the category mainly in the sense it took on through Herman Bang's adaptation, i.e., as a kind of literary behaviourism limiting authorial intervention. Nevertheless, some common denominators in the definitions scrutinized above can be traced and might prove helpful in drawing closer to an understanding of the term: (I) the tendency to consider literary impressionism as intersecting with the history of painting, a connection visible in writerly attempts to adopt the visual lexicon (subjects, themes, techniques) of pictorial impressionism; (2) the interpretation of impressionism as a subjective reaction to naturalism, 
the presumed objectivity of which is hence superseded or completed; (3) the novelty of the impressionist technique of montage uniting instantaneous impressions independent of logical patterns. 



\section{4 . \\ HIGHLIGHTS IN THE SCANDINAVIAN DEBATE ON LITERARY IMPRESSIONISM}

To prove impressionism's all but homogeneous connections with Scandinavian literature, I will now concentrate on three moments involving significant actors on the late nineteenth-century literary scene as well as highly divergent views on the relationship between impressionism and literature. An overview of Herman Bang's poetics of impressionism will be put forward; firstly through an examination of both early and present-day critical reactions to his prose and, secondly, through the scrutiny of the writer's own reflections on the impressionist revision of narrative traditions.

Next, I will look at how the definition 'impressionists', in the the meaning of «independents», «falangists», and «revolutionaries» (Brummer 2002: 77), lived on in Hans Jæger's and Christian Krohg's use of term in the second half of the I88os and in the radical bohemian social milieu in the Norwegian capital. In addition, I will also consider Jæger's interpretation of the term as a subjective turn of naturalism, which connects to the idea of impressionism as a displacement, a superseder, or a completion of naturalism that is common, as we have seen, in the handbook definitions scrutinized above. Jesse Matz (200I: I22) also connects to this idea when claiming that «impressionism forever dissociated realism and objectivity».

To conclude, I have found it indispensable to consider the case of August Strindberg, whose manifold talent and heterogeneous interests make him something of a seismograph, constantly detecting and measuring the intensity of movement in the late nineteenth-century Swedish cultural climate. As we will see, the, presumably, impressionist qualities in his writing have been - and are still being - discussed by several authoritative Strindberg scholars, while the writer's early exposure and personal reactions to painterly impressionism, which we will also take a closer look at, form an encounter perhaps even more suggestive than any stylistic evaluations of his prose. 
The introduction and assimilation of impressionism into Danish literature is mainly due to the writer Herman Bang's (I857-I9I2) adaptation of the term and to the literary scholar Sven Møller Kristensen's influential study from I955, Impressionismen $i$ dansk prosa, a re-edited version of an earlier work bearing the title Astetiske studier $i$ dansk fiktionsprosa 1870-1900 (Aesthetical Studies in Danish Fiction 1870-1900) dating back to I938. Bang's practice and Kristensen's theorization have rendered literary impressionism «et veletableret begreb» (Heitmann I988: 54; «a well-established concept») in Danish literature, an assessment confirmed by the more prominent position that the notion has achieved in histories and dictionaries of Danish literature compared to what is the case in the other Scandinavian countries, as we have been able to observe ${ }^{2}$.

Though Kristensen's work proposes a broad, panoramic view of the aesthetics of the phenomenon through stylistic analyses of texts produced by writers as different as Topsøe, Schandorph, Jacobsen, Drachmann, Bang, Pontoppidan, Gjellerup, Jørgensen, Stuckenberg, Rode, and Wied, among others, the name of Herman Bang remains the one most intimately connected with literary impressionism in Denmark 3 . In the hands of Bang, literary impressionism became a form of telling that strived to leave the territory of epic narration in an attempt to draw closer to the drama. As such, Bang's impressionism is modelled by a rather small number of norms regulating the position of the narrator and, as a consequence, the methods of describing and

I Astetiske studier i dansk fiktionsprosa 1870-1900 builds on Møller Kristensen's doctoral thesis from 1927 .

2 See also, e.g., Busk-Jensen, Dahl, Gemzøe, Grodal, Holmgaard, and Zerland, I985: 409I6. Johannes Fibinger's and Gerd Lütken's Litteraturens Veje (The Paths of Literature) even contains a section on impressionist painting because of its impact on the other arts, resolving that «i Danmark bliver impressionismen [...] et litterært program» (Fibinger and Lütken 2004: 216; «in Denmark impressionism [...] becomes a literary programme».

3 Cf., e.g., Busk-Jensen, Dahl, Gemzøe, Grodal, Holmgaard, and Zerland: «Herman Bang var den danske forfatter, der mest gennomført experimenterede med en impressionistisk fremstillingsform» (I885: 4I3; «Herman Bang was the Danish author who most thoroughly experimented with an impressionist form of narration»). As Torbjörn Nilsson has observed, the definition 'impressionist' was used already in contemporary reviews of Bang's work: Edvard Brandes recurred to it when reviewing Stille Eksistenser (Silent Lives) in Politiken, I2 November ı886, to define Bang's «reprehensible style» that according to Brandes imitated impressionist painting (Nilsson I965: 330, note 56), Jonas Lie also used it on the subject of Bang's Stuk (Stucco) in Dagbladet, 23 December I887, and in Politikken, 27 December I887 (Nilsson I965: 330 note 57). Concurrently, Bang himself adopted the term to comment both on his own style, e.g., in a letter to Peter Nansen (Nilsson I965: 225), and on that of his fellow writers: in a review entitled En ung fransk Forfatter (Politikken, 24 April ı886; A Young French Author) he defined Paul Bourget's criticism «en Impressionismens og de vendelige Stregers» (Nilsson I965: 330, note 55; «that of impressionism and of random connections»). Nilsson also points out that Bang, in a letter to Jonas Lie dated 3 November 1889 , on the subject of the negative comments his novel Tine had received, asked the Norwegian writer to put in a word for «den impressionistiske roman» (Nilsson I965: 124; «the impressionist novel») to help him out. 
reporting. In the main, Bang advocated the disappearance of the omniscient narrator acting as a mediator between the fictional characters and the reader; consequently, if the narrator is self-exiled from the story, he then has to make every effort to steer clear of authorial commentary and analysis, favouring what is known as the art of 'showing' as opposed to that of 'telling'4. The apparently limited access that the narrator has to the minds of the characters leads to a character description reminiscent of the behaviourist school of psychology: nothing but what can be observed from the outside is reported.

Similarly, the approach to conversation is seemingly independent of the narrator's guidance. Speech and dialogue, especially when involving a great number of characters, are reported pell-mell and come together in what Busk-Jensen, Dahl, Gemzøe, Grodal, Holmgaard, and Zerland, possibly drawing on Møller Kristensen's terminology (I955: 3I), define as a «replikmosaik» (I985: 4I6; «mosaic of lines»), i.e., conversations that might lack order and clarity but wish to gain truthfulness to life through the author's attempt to present 'un-edited' speech. Again, the narrator does not arbitrate between the scene and the reader, and the task of finding connections and causalities is entirely entrusted to the latter's ability to piece together details and situations (cf., Møller Kristensen I967: 153). According to Møller Kristensen (Ibidem), the lack of connectors between phrases and scenes, easily observed in Bang's novels, is mirrored even on the syntactical level, where Bang organizes his sentences paratactically.

The paragraphs that follow will seek to trace Bang's impressionist prose, first through an introductory overview of the major scholarly contributions on the question of Bang's impressionist style and, secondly, through his own written statements on the subject.

\subsubsection{On the subject of Bang's impressionism}

Scholars like the aforementioned Sven Møller Kristensen (1955 and 1967) as well as the Swede Torbjörn Nilsson (1965) have, in significant studies, concentrated on impressionist features in Bang's art of writing. Aspects of Bang's impressionism are also discussed in Sørensen 1986, Bouquet I983, Holm-Petersen 197I, Lundevall I953, and Christensen I9I8. Georg Christensen's article Herman Bangs teknik (Herman Bang's Technique) is interesting as it supplies a very early understanding of Bang's impressionist narrative mode, here interpreted in terms of a disruption of the balance regulating what the scholar calls «the four basic elements» (Christensen I9I8: 65) in epic narration: «referat» («background information»), «beskrivelse» («description»), «ræsonnement» («analysis»), and «replik» («direct

4 See e.g., David Lodge's essay Showing and Telling, which throws light on this aspect of narrative art (Lodge I992: I2I-24). 
speech»). Let us start the investigation of Bang's impressionism with the guidance of Christensen's helpful fourfold dissection.

When bridging the gap between epic narration and the drama, Bang's efforts eschewed any background information on the characters' names, ages, looks, or relations in diegetic passages given by the narrator. Instead, he preferred the in medias res technique and the use of dialogues as a means of channelling these details to the reader (cf., Christensen igi8: 66)5. Secondly, as to description, Bang marked his distance from the meticulous depiction of the naturalistic writers by bringing in, on the one hand, glimpses of significant details only - a method in itself inseparable from impressionist perception, in line with which an abundance of information is not helpful in making the addressee see, the risk being that of 'not distinguishing the forest because of the trees'. On the other, Bang also attempted to communicate individual impressions through the eyes of the characters ${ }^{6}$.

Instead of psychological analysis, the third of Christensen's four elements, commonly offered through the words of the narrator, Bang unfolds his characters by calling attention to those actions, gestures or intonations that truly reveal them. As Nilsson observes, Bang fully accomplished this aspect of his impressionist technique in the central scene of Ved Vejen, the before mentioned day trip to the market:

Också här sker klarläggandet av känslorna huvudsakligen genom att endast reaktioner noteras. När Huus nämner sin förlovning men ej hunnit säga, att den är uppslagen, tappar Katinka det hon håller i händerna. Det sker inte, som det gärna gjorde i Bangs tidigare produktion, genom en våldsam reaktion, utan händelsen noteras i förbigående, närmast som var den ett tillfälligt slarv. (Nilsson I965: I8I-82)

Here, too, feelings are clarified mainly through the mere annotation of reactions. When Huus mentions his engagement, be-

5 See for example the opening lines to Ved Vejen: «Stationsforstanderen skiftede Frakke til Toget. - Satan til lidt Forslag i Tiden, sagde han og strakte Armene. Han havde blundet saa smaat over Regnskaberne» (Bang I920-2I: 7. English translation by Tiina Nunnally in Bang I990: 9; «The stationmaster changed his jacket for the train. 'Damn, how time flies,' he said, stretching his arms. He had been dozing a little over the accounts»). Ved Vejen, literally "by the (rail)road", has been translated into English with the title Katinka.

6 As an example, Christensen compares Katinka's and Huus's views of the natural landscape to Bai's differing vision of the same scenery as the threesome sets out on the trip to the market: «det er et exempel bland mange paa, at Bang ikke giver det faste billede af omgivelserne i hvile, det objektive billede naturalisten tilstræber, men det impressionistiske enkelttræk, som kommer til bevidsthed [...] og som hidfører forskellige reaktioner og associationer hos hver enkelt» (I9I8: 67; «this is one of many examples indicating that Bang does not offer fixed depictions of still surroundings, those objective images to which the naturalists aimed, but rather the impressionistic details that enter consciousness [...] provoking reactions and associations that differ according to the individual perception»). 
fore revealing that it has been broken, Katinka drops the things she is holding in her hands. There are no violent reactions, as in Bang's earlier production, the event is instead registered in passing, rather as if it were the result of haphazard carelessness.

As to direct speech, finally, Bang's method was one of simultaneity, achieved through the use of polysyndeton and streams of scenes with characters appearing and acting in chorus, all in an attempt to create what Christensen quite appropriately defines as «dramatisk illusion» (I9I8: 73; «dramatic illusion»).

Other interesting contributions focussing, even though at times only partly, on Bang's impressionism, are Lindén 2009, Thomsen 2003, Gravier I967, and Jacobsen I957. In Thomsen's reading of Herman Bang's I896 novel Ludvigsbakke, the work is interpreted as «en impressionistisk roman, $\mathrm{i}$ den betydning Bang har giver [sic] ordet» (2003: 96; «an impressionist nov$\mathrm{el}$, in the sense that Bang has given to the term»). Thomsen subsequently (97) sums up Bang's literary impressionism as a narrative mode centred, again, on four main approches, through which the non-intruding impressionist writer, desisting from authorial explanation and commentary, is nevertheless able to grasp the thoughts and the feelings of his characters: (I) through the description of actions mirroring the workings of the mind of his fictional creatures; (2) through comments and dialogues pronounced by the characters, and through the use of indirect speech; (3) through the adoption of a mobile point of view; (4) through the use of objects and physical surroundings which, in a famous expression by Bang himself, which we will soon look closer at, act «as transparent shells revealing the inner story».

The attention Thomsen gives to the author's treatment of objects and space adds something new to Christensen's reading of Bang's impressionism. According to Thomsen, the use of «rum og ting som udtryk for personligheden» (2003: 98; «space and objects as expressions of personality») constitutes a peculiar dimension of Bang's technique, especially in the way it is conducted in Ludvigsbakke. Thomsen writes: «på denne måde at inddrage civilisationens ting i psykologien er et af de nye træk ved Bangs impressionisme, en teknik der i det videre forløb gør grænsen mellem ting og bevidsthed flydende» (2003: III; «drawing the objects of civilization into psychology in this way is one of the new characteristics of Bang's impressionism, a technique, which in a broader sense makes the limit between object and consciousness fleeting»). In its most radical form, Bang's attempt to establish a connection between consciousness, on the one hand, and objects and space, on the other, leads us, Thomsen further asserts (Ibidem), to literary phenomenology, symbolism and vitalism.

Phenomenology is also guiding Axel Lindén's reading of a number of texts written by Bang. When Lindén focusses on the use of objects (the 
scarf, the tray) in Ved Vejen, he considers their symbolic value more than anything else. Symbolic value aside, as it is unquestionable, the objects present in this novel are however, in my opinion, also reminiscent of the Oriental artefacts that streamed into impressionist paintings at the end of the nineteenth century. In the case of the lacquered tray, Bang takes care to determine its provenance: «Huus havde købt Katinka en lille japanesisk Bakke i Markedsgave» (I920-2I: 80; «Huus had bought Katinka a little Japanese tray as a souvenir of the market» 7 ) and also dwells on the scenes depicted on the blue and white Chinese porcelain in Katinka's childhood home; is it possible, then, that Bang incorporated these objects as props in his narrative, i.e., that he awarded them the function that they have in impressionist painterly compositions? In a commentary directed at the critic Erik Skram entitled "Impressionisme". En lille Replik (Impressionism". A Brief Reply), which we will shortly take a closer look at, Bang had, at any rate, shown his awareness of the two-dimensional aesthetics and the methods of composition in Japanese woodblock prints, and likened the technique of the impressionist writer precisely to this representational mode, which, according to Bang, was of Chinese origin: «han rykker nemlig, tror jeg, hver eneste Enkelthed frem i det samme Plan [...] og hans Billede bliver uden Perspektiv. Det synes saaledes, som om han har kinesiske Øjne» (Bang I89oa: 693; «he pulls, indeed, I believe, every single detail onto the same surface level [...] and his picture lacks the third dimension. Therefore, he seems to have Chinese eyes»).

A new reading of Bang's impressionism was advanced in 2003 by Dag Heede, a scholar who has made it his mission to queer the canon of Danish literature. On the basis of Heede's understanding of Bang's article Gedanken zum Sexualitätsproblem (Thoughts on the Problem of Sexuality) - dealing with the conditions of the homosexual literate and artist, posthumously published in 1922 - as «en skitse til en impressionistisk poetik» (Heede 2003: 34; «a draft for a poetics of impressionism»), the Danish scholar interprets Bang's leave-taking from naturalism and the subsequent adoption of impressionism as a development with a «seksualitetsteoretisk dimension» (Ibidem; «sexual-theoretical dimension»):

Man kan således måske - også - søge en af impressionismens rødder eller forudsætninger i Herman Bangs seksuelle outsiderposition, hvor han ikke mener at kunne give sine følelser direkte udtryk og ikke ønsker "eine ewige Maskerade" (måske som i tilfælne med Kamilla- og Eva-skikkelserne fra Haabløse Slocgter). I stedet bliver han så “iagttager”, en position, der kan kobles til den impressionistiske fortællekunst, der opererer med en ekstrem diskret (ikke "passiv") fortælleteknik. (Heede 2003: 34)

7 Translation by Tiina Nunnally, Bang I990: 85 . 
Perhaps one might therefore - in addition - look for impressionism's roots or conditions in Herman Bang's sexual outsider-position, from where he doesn't allow his feelings direct expression and doesn't wish for "eine ewige Maskerade" (as perhaps in the case of the Kamilla- and Eva-characters in Haabløse Slocgter). Instead he becomes an "observer", assuming a position which connects to the narrative art of impressionism that employs an extremely discreet (not "passive") technique of narration.

This «extremely discreet» narrator striving for invisibility has also been discussed by Philippe Bouquet. When Bang, on the level of the graphic distribution of the text, favoured the dash, it was, according to Nilsson (I965: I05), done in order to separate one scene from the other, or to isolate a comment within a scene. Moreover, the dash also plays an important role in managing the speed and the beat of text, and the ellipsis points, which, according to Nilsson, have the function of representing «det abrupta i framställningen: att här fanns mer att säga, men att dramat, en gång satt i rullning, liksom av egen kraft tvingas att spela upp sig själv» (Ibidem; «the abrupt aspect of the narration: [indicating] that there was more to say, but that the drama, once in action, had to rely on its own force»). According to Bouquet, these stylistic features in Bang's prose are actually at odds with the impressionist ideal of a hidden author. In the article L'Impressionnisme paradoxal de Herman Bang dans Ved Vejen (Herman Bang's Paradoxical Impressionism in Ved Vejen), Bouquet maintains that the presence of the author, which Bang strived to suppress, was actually made visible through this typographical choice, «par des guillemets et des italiques qui ne peuvent manquer de rappeler son existence» (Bouquet I983: 423; «through brackets and italics that cannot help reminding [the reader] of his [the author's] existence»).

\subsubsection{Bang on Bang}

Around I885, it is generally agreed, Herman Bang had developed a new conception of the art of the novel ${ }^{8}$. As Torbjörn Nilsson observes (I965: III), Bang expressed his opinions in an article published in Göteborgs Handels- och Sjöfartstidning on 21 October I885. If Bang's insights into the role of the narrator in prose fiction already had been outlined in I879 in his collection of articles entitled Realisme og Realister (Realism and Realists), Nilsson concludes that a «frontförändring» (I965: III; «a change of position») occurred with his I885 article. Here, Bang clearly signalled his distance from works of literature abounding with authorial description and analysis, and declared to favour a

8 Cf., Nilsson i965: III, Busk-Jensen, Dahl, Gemzøe, Grodal, Holmgaard, and Zerland I985: 237 . 
different technique, reminiscent of dramatic writing and concentrating on the representation of action, gestures and dialogues. After a first attempt to adopt this new-fangled style in Charlot Dupont (Nilsson I965: I60), the third short story in the collection Excentriske Noveller (Eccentric Short Stories) from I885, this method was further developed in Ved Vejen, published as one of the short stories forming the collection Stille Existenser (1886), followed by the stylistically similar Stuk (I887), Tine (I888), and Ludvigsbakke (I896).

In in a number of writings published in the following decades, Bang personally presented his particular technique, often by recurring to the expedient of directing the interest to Jonas Lie's mastering of the same narrative mode: by introducing his viewpoint on Lie's art of fiction, it has been observed, Bang really spoke of his own ideals 9 . The five essential texts that Bang produced on the subject of literary impressionism are: (I) the review To Bøger (Two Books), partly dedicated to Jonas Lie's novel Majsa Jons, published in Dagbladet on I2 January I889 (Bang I889); (2) a homage to Lie's mode of narration entitled Til Jonas Lie (To Jonas Lie), which would come to feature as foreword to Bang's own collection of short stories Under Aaget (Bang I8gob; Under the Yoke); (3) "Impressionisme". En lille Replik, a text published that same year and in the form of a letter, in response to the critic Erik Skram who, in a rather harsh tone, had criticized Under Aaget and compared Bang's impressionism to painterly impressionism, finding this connection a weakness (Bang I89oa); (4) the article Jonas Lie, published in Samtiden I893 (Bang I893), and, finally, (5) the homonymous article, Jonas Lie, published in Tilskueren in I908 (Bang I908). Let us now take a closer look at the way in which Bang articulated the issue of literary impressionism in these writings.

In the foreword to Under Aaget, the words of praise directed at Jonas Lie in person stem from Bang's admiration for the Norwegian writer's innovative dramatic art of 'showing':

De er $i$ et afsides Land $i$ en ny Literatur naaet til at skabe Fremskridt i Romanens Form, som ikke er naaet af nogen Samtidig i selve Romanernes Land: i Frankrig. De aldrig fortæller noget om noget. De viser os alt. Fortælling om en Ting er som et Gevandt om Genstandens Krop. Man skal gæette Legemet, der gemmes bag Gevandtet. Men De henstiller det af Deres Digterhjerne Sete umiddelbart, som det staar og det gaar og det be-

9 Cf., Busk-Jensen, Dahl, Gemzøe, Grodal, Holmgaard, and Zerland i985: 678, who also find it likely that Bang, in his writings on Lie, was really describing his own art of narration as much as that of the Norwegian novelist. Bang certainly turns the attention to himself when he speaks of «den, der har forsøgt selv at følge Jonas Lie og maaske endogsaa teknisk at udvikle den impressionistiske Form og føre den endu videre (navnlig ved at studere den forraadende Bevægelsen)» («he who has himself tried to follow in Jonas Lie's footsteps and perhaps even to develop the technique of impressionist form even further [namely through a study of revealing movements]»). On Jonas Lie’s influence on Bang see also Sjöwall iو67. 
væges, for vort Syn, saa vi hører det, sér det, fornemmer det, i sin Bevægelighed, i sit Liv. (Bang I890a: I5)

Within the young literature of a peripheral country you have managed to renew the form of the novel, something that has not been done by any of your contemporary writers in the land of the novel: France. You never tell us anything, you show us everything. To narrate something is like a draping over the body of things. You need to be able to trace the body hidden in the drapery. But you represent what your poet's brain has seen immediately, the way it stands and walks and moves, before our eyes, so that we can hear it, see it, feel it, in its movements, in its life.

In the same foreword, Bang glorifies Lie's novel Majsa Jons with an expression anticipating the one he would use to explain literary impressionism to the Danish public: «Majsa Jons er et Skuespil. Et fremstillet Skuespil» (Bang I89ob: ı6; «Majsa Jons is a drama. A represented drama»).

The exchange of opinions between Skram and Bang becomes particularly interesting as Skram introduces the question of the interrelation between the arts - a problem hitherto irrelevant to Bang's discourse on impressionism - when trying to explain the characteristics of literary impressionism. Skram writes: «det ligger nær at jævnføre denne literære Hurtighedskunst [...] med Malernes Impressionisme» (I890: 479; «it is easy to compare this hasty art of narration [...] to the impressionism of the painters»). As mentioned above, this connection between painting and writing was a flaw and a frailty to Skram, according to whom any form of art transmitting sensorial impressions, without engaging the rational knowledge of the mind in the process of translating the impression to words or visual images, was unsatisfactory and limited in scope:

i Længden vil vi næppe have nok i en Malerkunst, der med velberaad Hu kun fremstiller de blotte fysiske Skranker for Malerens Synsævne, eller i en Digtning, der alene søger at eftergøre, hvad der i det enkelte Øjeblik umiddelbart foregaar. (Ibidem)

in the long run we will not be satisfied with an art of painting that makes a point of simply representing the plain physical obstacles that appear before the painter's eye, nor with a literature merely seeking to portray that which immediately goes on in one single instant.

Skram therefore prophesied that Bang's mode of narration, as well as its painterly counterpart, would both end up being rejected by the public. In response, Bang presented his «lille Replik» in an attempt to counter some of the objections that Skram had directed against «'Impressionismens' Væsen 
og Fremgangsmaade og særlig imod mig» (Bang I89oa: 698; «the nature of impressionism and its representional mode and especially against me»), and set out to prove that what Skram saw as the shortcomings of impressionist narration really were its assets:

Impressionismen i Fortællekunsten er netop Barn af den fuldkomne Mistillid til ‘den psykologiske Roman”s 'Dvælen og Overvejelser' [...]. Kun den i Handlen omsatte Tanke tror Impressionisten, at hans Erkendelse magter at følge. [...] Som al Kunst vil ogsaa den impressionistiske Fortællekunst gøre Rede for de mennesklige Følelser og for Menneskers Tankeliv. Men den skyr al direkte Udredning og viser os kun Menneskenes Følelser i en Række af Spejle - deres Gerninger. [...] [O]g han medtager i sin Skildring i Virkeligheden kun de v æ s e $\mathrm{n}$ t 1 i g e Handlinger, det vil sige en Handlingsrække, hvor hver lille Handling er et Glughul ind i det skildrede Menneskes Tankeliv en Række af Udfaldsporte ind i Følelseslivet hos den skildrede. Summen af Tanker, Vævet af Følelser, som den drevne Hjærne saaledes kan naa bag om de medtagne Handlinger, er det impressionistiske Værks dulgte Indhold. Dets Værd beror paa Dybden af alt det - som ikke siges ${ }^{\text {Io }}$. (Bang I89ob: 692-693)

Within the art of narration, impressionism stems from the utter distrust of the 'meditation and reflections' of 'the psychological novel' [...]. The impressionist is convinced that his perception only manages to report thoughts that have been transformed into action. [...] Just like any other form of art, the impressionist narrative wishes to explain human emotions and the intellectual life of people. But it steers clear of all direct investigation showing us nothing but human emotions in a series of mirrors, i.e., human actions. [...] [A]nd he [the impressionist writer] really brings nothing but the e s s e $\mathrm{n} t \mathrm{i}$ a $\mathrm{l}$ actions into the narration, that is to say, a series of actions in which every little action is a spyhole into the thoughts of the narrated person - a series of doors opening onto the sentimental life of the subject of description. The sum of thoughts, interwoven by feelings, that the skilled brain can grasp behind the reported actions, is the hidden content of the impressionist oeuvre. Its value depends on the depth of all that remains unsaid.

With this in mind, Bang also claims that Skram's understanding of literary impressionism is excessively restrictive and that the impressionist description of events in a given moment is really a means to achieve depth: «de ydre Ting, han maler, er Kapslerne om den indre Historie. Paa Kapslernes Gennemsigtighed

Io Emphasis in the original. 
beror deres Værdi» (Bang I890a: 693; «the external things depicted are shells around the inner story. The value of these shells depends on their transparency»).

In the famous homage to Jonas Lie written in 1908 after the death of the Norwegian novelist, Bang returned to the idea, expressed in I890, according to which impressionism was synonymous with dramatic representation. In the 1908 article, Bang came to the conclusion that Scandinavians had better avoid «Fremmedordet 'Impressionisme'» (Bang I908: 678; «the foreign idiom 'impressionism'»), since its significance was likely to be obscure to the majority, and rather adopt the synonymous expression «den fremstillede Roman» (Ibidem; «the scenic novel»). In this article, Bang once more attributed the creation of «den impressionistiske Roman» (676; «the impressionist novel») to Jonas Lie, and explained the revolutionary traits of his transformation of the novel thus: «fra at fortælle - eller, tilgiv, undertiden snakke om Mennesker - naaer Romanen frem til at lade os sé, lade os leve sammen med Medmennesker - hvad der er den impressionistiske Romans Maal» (Ibidem; «from narration - or, please forgive, the ongoing talk about people - the novel manages to let us see and share the lives of fellow human beings - which is the goal of the impressionist novel»).

Again, it is the scenic quality of the narration that Bang highly appreciates, the writer's ability to put the reader into a position from where he «'sér, hører, føler' hvert eneste enkelt Ting, hvert Ord, Bevægelsen, Blikket, en ændret Mine, Tonefaldet, en Lyd i hvert skildret $\mathrm{Nu}$ - det er Alpestigningen, som Impressionismen fordrer» (677; «'sees, hears, feels' every single thing, every word, movement, look, change of face, intonation, every sound in every instant described - that is the mountain ascent that impressionism requires»). While the naturalists had failed - blinding the reader with overly detailed inventories - impressionism, according to Bang, produced a type of novel allowing the reader at all times to see and hear: «Impressionismen brød sig Vej: Romanen, som i hvert Nu lader os sé og høre» (Ibidem; «Impressionism gained ground: a novel which allows us to see and hear in every single moment»).

\subsection{THE AGE OF IMPRESSIONISM AND THE BOHÈME ${ }^{\mathrm{II}}$}

One of the circles in Scandinavia where writers, artists, and intellectuals early on made an attempt to apply the idea of impressionism to literature can

II According to Arnold Hauser (I999: I78), the «age of impressionism» produced an extreme grouping of bohemians, opposed both to the early «bohème of the romantic age» and to the «bohème of the naturalistic age» (I79). Though all these artist côteries demonstrated against the ways of the bourgeois world, the first generation of bohemian romantics (Gautier, Nerval) experimented with excursions into the underworld, but were «free to return to bourgeois society at any time» (Hauser I999: I80). Their followers (Murger, Courbet, Nadar, Champfleury) were in truth «an artistic proletariat» (I999: I80) but ended up romanticized and idealized by the bourgeoisie, while the third generation of bohemians, that of the impressionist age (Rimbaud, Verlaine, Corbière, Lautréamont), are seen as «a company of vagabonds and outlaws, a class in which demoralization, anarchy and misery dwell, a group of desperadoes» (I999: I8I). 
be traced within the context of the literary and social movement known as the Kristiania Bohème in the capital of Norway in the $188 \mathrm{OS}^{\mathrm{I2}}$. The frontiers of this modern bohemian milieu with its oppositional subculture seem, indeed, to merge with those of the impressionist movement as the definition bohemtiden (the age of the bohème), frequently used to characterize the period, ties in with Christian Krohg's view that future generations would come to look back at these years and consider them the «age of impressionism» (Krohg I886: I4). As an artist connected with the bohemian social environment, Krohg is no doubt overemphasizing his painter's perspective when stating, in his famous lecture Om den bildende kunst som led i kulturbevagelsen (On the Fine Arts as a Moment in the Cultural Movement) held at Den frisindede studenterforening (The Liberal Student Association) on 22 March I886: «ligesom man har opkaldt renaissansetiden og rococcotiden efter kunstretninger, saaledes vil man engang opkalde denne tidsalder efter impressionismen» (Krohg I886: I4; «just as the age of the Renaissance and the age of rococo have been named after artistic currents, this age will be named after impressionism») ${ }^{13}$.

Accordingly, these two spheres intertwine again in the choice of title for the mouthpiece of the Norwegian bohemians, the review Impressionisten, whose nine issues were published from I886 to I890 (Jæger and Krohg I886-90). In spite of its name, Impressionisten was not so much preoccupied with current trends in painting as with clarifying the radical bohemian writer's approach to modern man in modern society: the title might thus, at first sight, seem misleading. The bohemian understanding of the role and the function of literature drew on Zolaesque naturalism though encouraging, in addition, narrative concentration on introspection and on the writer's personal experience, an attitude that I will consider as part of the bohemians' impressionist stance.

Already at this stage it is worth noticing that such singular usage and acceptance of the concept of literary impressionism has little to do with the technique and the methods of composition of the impressionist painters: following Krohg's reasoning in the above-mentioned lecture, impressionism should rather be seen as the attitude assumed by tormented modern artists, illustrating their approach to, and direct engagement with, what Krohg indicates as their main object of investigation, i.e., «den nuværende søgende og stræbende tid» (Krohg I886: I2; «the searching and striving contemporary age»). This peculiar understanding of impressionism might seem improper within a general discussion of impressionist art; however, when Magne Malmanger observes that it would be erroneous to dismiss Krohg's ideas on impressionism «som provinsielle misforståelser av en kunstnerisk

I2 For a thorough discussion of the Kristiania Bohème, see Fosli I994.

I3 Den bildende kunst som ledd $i$ kulturbevegelsen is also available in a more recent publication, Krohg I995: 77-I2I. 
utvikling innsiktet mot helt andre problemer» (Malmanger 1987: 46; «as a provincial misunderstanding of an artistic development concentrating on totally different problems»), he stresses the fact that the essence of any art that aims at being modern is to give expression to contemporary reality by introducing the motifs brought about by modernity ${ }^{14}$. Through the description of contemporary men and milieus, impressionism had in fact, according to Krohg, contributed to the realization of «tidens store billede» (I886: I4; «the great image of the age»).

These observations on the modernity of impressionist subjects might give a first clue as to why the radical editors of Impressionisten through their choice of title signalled a wish to associate with the French artistic movement. In addition, it is worth remembering that, in the art world of the Norwegian mid-eighties, impressionism was still seen as le dernier $\mathrm{cri}^{\text {i5 }}$. In I886, the very same year that the French impressionists organized their last group exhibition, impressionism was still the art of a rebellious opposition in Scandinavia, encapsulating the idea of being on the edge and anti-bourgeois in character. A similar chronological discrepancy is also in an international context, according to Arnold Hauser (I999: I67), generally visible in the relation between literary impressionism and its painterly counterpart: «in painting, the most productive period of impressionism is already past, when its stylistic characteristics are first beginning to emerge in literature».

\subsubsection{The bohemian stance}

In the heydays of objective naturalism and false morals, the leader of the bohemian movement, Hans Jæger (I854-I9I0) advocated a turn towards autobiographical writing and free love for all, aspects of the bohemian lifestyle that he also did his best to enact. In the following paragraphs, I will focus on how the concept of impressionism linked up with the turn to the subjec-

I4 As Bernard Vouilloux writes: «Assurément, ce à quoi les moins hostiles des premiers spectateurs de tableaux impressionnistes étaient sensibles ou réceptifs, cétait d'abord la 'modernité' des sujets traités, pour autant que le décor urbain, le costume et tous les accents de la vie contemporaine, avec les situations et les gestes qu'ils appellent, exclus de la peinture d'histoire, n'avaient été admis ou tolérés que dans les degrés inférieurs de la hiérarchie académique des genres» (2000: 68; «That to which the least hostile first spectators of impressionist art proved sensitive or receptive to was unquestionably the 'modernity' of the subjects treated, since the urban scene - the style and all the aspects of contemporary life, with the situations and the behaviour it turned to - had been excluded from history painting, and not admitted or tolerated unless confined to the lowest parts of the academic genre hierarchy»).

I5 Malmanger (1987: 34) observes that it was Erik Werenskiold who officially introduced the Norwegians to impressionist art in the article Impressionisterne (The Impressionists) published in Verdens Gang as late as in I882. According to Malmanger (1987: 33), in the mid-eighties impressionism was «dagens parole» («the expression of the day») and «et ord som rigtignok for mange betegnet lite mer enn det nyeste nye» («a word that to many, quite correctly, indicated a little bit more than the very latest news»). 
tive in Jæger's literary programme and try to account for his vision of a new bohèmliteratur as it comes forth in the foreword to his first novel, Fra Kristiania-Bohêmen (1886; From the Bohème of Kristiania), and in his contributions to the review Impressionisten, of which he was co-founder. Jæger's subjective naturalism coincided with the idea of literary impressionism in the eyes of his friend and fellow-writer, the aforementioned Christian Krohg, with whom Jæger edited this short-lived review. Let us take a look at the way in which Krohg established a connection between Jæger's literary programme and impressionism, and turn to the review Impressionisten in an attempt to trace one of the early understandings of literary impressionism in Scandinavia ${ }^{\mathrm{I}}$.

As mentioned above, in spite of its title Impressionisten offers little for the scholar interested in the adaptation of impressionism to fiction as interart transposition. The review mainly contains the, often autobiographical, writings of Jæger (at times indeed labelled «impressions»), coverages of the trial against his first novel Fra Kristiania-Bohêmen, which had caused a moral scandal in Norway, reviews of books, plays, and art exhibitions, political comment, as well as translations of texts by foreign writers such as Émile Zola and Guy de Maupassant. The choice to include these two French writers in translation is a key to understanding the literary taste of the editors, and it is worth mentioning that in the history of the fortune of literary impressionism as a critical term, Zola is at times seen as a writer capable of linking the 'impassible' mode of naturalism to that of impressionism ${ }^{17}$. Moreover, Maupassant, occasionally considered a forerunner of literary impressionism was, according to Krohg, one of the only two impressionists in world literature, as we will see ${ }^{\mathrm{I} 8}$.

The editorial board outlined the purpose of the review in the second issue, published in December i886, as follows:

Foruden at leverere literær kritik og hyle hvergang der er noe, vil "Impressionisten" ogsaa gjøre seg til organ for alle slags smaa Kristiania-impressions og derved bidrage sit til at fulstændiggiøre det store Kristiania-billed fra vor tid, som skal skabes af den Kristiania-literatur, der nu værs'go faar være saa snil at blomstre op. ('Red' ı886)

Apart from delivering literary criticism and roaring whenever something comes up, Impressionisten also wishes to make itself

I6 For a discussion of impressionism in Impressionisten see also Lund (I993: 49-5I) and Malmanger 1987.

I7 See for example Deffoux I928, Hoppe I933, Matthews i96I, Hamon I967, Nagel I982: Io. In short, Kronegger (I973a: 37) claims that «Zola, in 'Salon de I865' anticipated impressionism in saying that an artist should express his personality and his temperament, and not reproduce reality».

I8 See for example Schneider I934, Basílio 2007. 
an organ for all kinds of small Kristiania-impressions in order to help to complete the great Kristiania-picture of our age that is to be created by the literature of Kristiania, which now will have to be so kind as to start blooming.

The statement is signed Red (the Editorial board), but it is likely that editor-in-chief of the first four issues was Krohg only, as Jæger, due to the moral scandal caused by his first novel, was imprisoned at the time of publication. In addition, the idea of art and literature as an image of the times is, as we will see, a slogan easily recognized as coming from Krohg, one that derived from his need to find expression for an acutely felt sensation of living in a new, franticly modern era. In his writings, Krohg is very much concerned with the need for art to transmit «tidens billede» (1886: I3), an image of the contemporary age and its people, and indicates Jæger as the most exemplary child of that time, the one with the greatest aptitude of all Norwegian writers to describe modern age and modern man (Krohg I886: I4).

Clues to the understanding of Hans Jæger's literary methods can be found in some of his contributions to Impressionisten. In the second issue, he delivered the first part of an article entitled Vor literatur (Our Literature) on the subject of modern literature and modern youth, in response to Georg Brandes's opionion that both were still as good as non-existent in the Norwegian I88os. To Jæger in I886, 'modern' was still synonymous with 'naturalistic': he declares his admiration for modern French literature (Zola's novels, Maupassant's Une Vie [A Life] and Bel-Ami) and, with the exception of Jonas Lie, clearly demonstrates his dissatisfaction with the «farcical plays» and «bloodless stories» of the Norwegian naturalists (Jæger I886). What he advocates is greater individual expressiveness. The essence of Jæger's literary programme, presented in the article, embraces two main elements: the necessity to write about personally lived-through experiences and the defence of sensory experience. He therefore, on the one hand, asks the modern youth - in overly explicit metaphors - to «klæ sig selv af» («undress») and «fremstille sig for offentligheden i al sin nøgenhed» («show themselves naked in front of the public»), shamelessly exhibiting in public their private lives (Jæger i886). On the other, he professes his belief in writers such as Zola and Maupassant, capable of making the reader see, hear and feel. This principle leads Jæger to dismiss the Danish writer J.P. Jacobsen's collection of poetry, Digte og udkast (Poems and Sketches), also reviewed in the second issue of Impressionisten. Although the bohemian is ready to admit that Jacobsen, who as early as I883 had been identified precisely as a literary impressionist by the Norwegian critic Henrik Jæger, «altid seer og skriver som en maler» (Jæger I886; «always sees and writes like a painter»), his poetry is rejected on the grounds that Jacobsen is trying to 
paint without succeeding in making the reader $\mathrm{see}^{\mathrm{I} 9}$.

This far there is nothing that explicitly connects with impressionism in Krohg's appeal that artists and writers should contribute to the creation of «tidens store billede» (Krohg I886: I4; «the great image of the age») and in the naturalism with a "Jægerian" twist. The leader of the Bohème, quite at ease with defining himself a naturalist, claimed, just like his forerunners, that a writer should tell stories of human misery and dissolution though, in Jæger's case, these stories eventually became his own, thus opening the way to 'bohemian' impressionism. Jæger's interpretation of this impressionist's stance is put forward in an article entitled Albertine og naturalismen (Albertine and Naturalism), published in the fourth issue of Impressionisten in I887, dedicated to Christian Krohg's novel Albertine, on the theme of public prostitution, and to his painting with the same subject, Albertine $i$ politilegens ventevarelse (Albertine at the Police Doctor's Waiting Room). Here, Jæger accounts for his personal interpretation of how an impressionist's writer should approach his subject matter and accuses Krohg of not having lived up to the standards of a true impressionist. Direct observation and empiricism are, according to Jæger, the principal traits of the impressionist school, and Krohg is found guilty of not having conducted any field research in Kristiania's infamous Vika-area, where his story is set:

Er det dog ikke dig som sier du er impressionist? - og saa gaar du hen og vil gi os, ikke den impression du virkelig har faat, nej, men et hel menneskeliv som du aldrig har kjendt, og som du følgelig ikke har kunnet faa noen impression af! (Jæger I887; italics in the original)

Are you not the one claiming to be an impressionist? - only to go ahead and give us, not your real impression, no, but an entire human life that you have never got to know, and therefore have not been capable of getting any impression of!

On these grounds Jæger rejects Krohg's Albertine-project, both novel and painting, the latter «ikke det mindste mere impressionistisk enn bogen» (Ibidem; «not the least more impressionist than the book»). However, he concludes his piece of writing once more addressing Krohg-the-impressionist, confident in a positive future development:

I9 According to Hans Lund (I993: 48-49), Henrik Jæger was the one who introduced the term 'literary impressionist' in Scandinavia by using it in an article entitled Om J.P. Jacobsen som novellist (Jæger I883; On J.P. Jacobsen as a Writer of Short Stories). Lund also calls attention to the fact that Brandes compared Jacobsen's style to that of his contemporary painters and mentions the Swedish critic Nils Erdman, who spoke of modern impressionism with reference to Jacobsen's literary methods (Lund I993: 46-47, 49). 
Det skal være dig tilgit, at du, impressionisten, denne gang har git dig ud paa at skildre ukjendte mennesker fra en sfære du ikke kjender - det skal være dig tilgit, for jeg ved du gjør det ikke mere. Næste gang vil du gi os mennesker du kjender, mennesker fra den sfære hvor du selv hører hjemme, og af hvis livsskæbner du faaet virkelige impressions. (Ibidem)

We shall have to forgive you, the impressionist, for having set out this time to describe unknown people from an environment you have no knowledge of - we shall have to forgive you, as I am certain you will not do it again. Next time you will show us people you know, people from your own environment whose destinies you have caught real impressions of.

How, then, does Jæger's interpretation of impressionism differ from the basic principles of naturalism? In what way is the heartfelt need for rendering «real impressions», i.e., empirical, firsthand, impressions of people and places belonging to an environment familiar to the artist, different from the scientific observation of a naturalist?

Hans Jæger's imperative that the writer should represent what he has seen and what he knows from personal experience only, would lead him to conclude that the literature that was in the making by the modern youth of Kristiania really encapsulated nothing but 'writing one's own life'20. Although Jæger stuck to identifying himself as a naturalist, he was, at the same time, marking his distance from Brandesian analysis and problemdebat, striving instead to be 'modern' and 'subjective': in criticizing Krohg, as we have seen, he is prompting for an 'empirical' and 'impressionist' approach to the objects of artistic desciption. These four adjectives stand as closely as synonyms, but may need further explanation: why associate Jæger's deviations from the norms of naturalism, which would lead him to investigate his own private life, precisely with impressionism? How does subjectivity relate to impressionist writing? In other words, in what way is confessional, self-analytic or autobiographical literature characteristic of impressionism?

Christian Krohg is responsible for this interpretation. In Om den bildende kunst som led $i$ kulturbevogelsen, Krohg tried to prove in what way Jæger's standpoint really was representative of impressionism. According to Krohg, it is the subjectivity of each and every individual involved in the collective realization of «tidens store billede» (I886: I4; «the great image of the age») that leads to the success of the project. Quoting Manet, Krohg writes that the contemporary scene cannot be described unless each artist, primarily each writer, allows his own subjective perception of the moment to shine through in his work:

20 The phrase «Du skal skrive dit liv» («You shall write your own life») was revealed in advance in the seventh issue of Impressionisten, in November I888, before appearing as the first of nine bohemian commandments in the eighth issue, February I889 (I889 Bohêmbud). 
Manet sa: Det er blot det indtryk som skal frem, det indtryk, som naturen giør paa os tidens børn, thi da faar vi tidens billede. Det gjælder altsaa først at være et tidens barn og dernæst at give sig selv i sit arbeide, at give sit had og sin kjærlighed, og det gjælder at leve og at hade og elske, for saa vil man $i$ hvert eneste værk - det være nu stilleben, landskab eller hvadsomhelst faa et lidet billede av tiden [...]. (Krohg I886: 13; italics in the original)

Manet said: It is the impression only that has to come forth, the impression that nature makes on us children of today - this is how we obtain the image of an age. Firstly, you will have to be a child in time, secondly, you will have to give yourself in your work, give your hatred and your love, and you will have to live and hate and love, because in this way, every single work - be it a still-life, a landscape or whatever, will offer an image of the age [...].

Krohg's request that the artist express his own personality is again reminiscent of Zola's and Taine's idea of an artistic temperament that was to appear in a work of $\mathrm{art}^{2 \mathrm{I}}$. The idea of a naturalistic temperament might indeed not seem very distant from the subjectivity that is at the heart of the bohemians' impressionist stance, but we will have to rememember that in naturalism the temperament itself never became the subject matter. The naturalist's subject matter - be it society, nature, or human beings - was to be seen through a temperament, whereas the impressionists came to the conclusion that the point of interest was not so much the subject matter itself as the artist's personal impression of the scene. This is, as I see it, the underlying idea of Krohg's acceptance of impressionism, an idea which led him to pronounce the words that identify Maupassant and Jæger as the two forerunners of the new vogue of literary impressionism. The reasons are, however, different: while the name of the Frenchman, according to Krohg, fits into the current mainly because of technical matters and a subject choice reminiscent of that of the impressionist painters - Maupassant is praised because of his ability to transmit atmospheres and impressions reminiscent of «en impressionistik farveskizze» (Krohg I886: I3; «an impressionist coloursketch») - Jæger finds himself a place in literary impressionism because of his temperament, a nervous restlessness which is both an expression of the modern age of impressionism (Krohg I886: I4) and the subject matter of the literary impressionist. In Krohg's opinion, Jæger seems to embody the impressionist stance of the empiric who strived to reduce, and came to eliminate, the distance between writer and subject. Krohg writes:

2I To stress his opinion, Krohg turns in fact to a quotation from Zola: «Ce, que je cherche avant tout dans un tableau - C'est un homme et non pas un tableau» (Krohg I886: I3, italics in the original; «what I look for in a painting is a man and not the painting»). 
Jeg kjender idetheletaget hidtil bare to impressionister i literaturen, det er Guy de Maupassant og Hans Jæger. Hans Jæger er nordens Manet. Han var en af dem, som ogsaa drog ud med sin malerkasse og sitt feltstaffeli. Han havde mer end nogen anden tidens uro og utilfredshed [...]. (Krohg I886: I2; italics in the original)

On the whole, I only know of two impressionists in literature, these are Guy de Maupassant and Hans Jæger. Hans Jæger is the Nordic Manet. He was one of those who took off with his painter's bag and his outdoor easel. He felt more than anyone else the anguish and the restlessness of this age [....].

The choice of words inevitably makes plein air-ism spring to mind, but rather than aiming at a comparison with the painters at the core of the impressionist movement, the reference is to Manet, who endorsed the impressionists but never took part in their exhibitions, which evokes the terrain in which impressionism was born and, with that, the way that was paved from naturalism to impressionism ${ }^{22}$.

\subsubsection{Christian Krohg: impressionism in writing and in the visual arts}

The words with which Jæger turned to Krohg in his dismissal of the novel Albertine - «Er det dog ikke dig som sier du er impressionist?» («Are you not the one claiming to be an impressionist?») - clearly endorse the idea of impressionism as a literary mode and ponders its applicability to Krohg's prose. Krohg, too, as we have seen above, used the term with reference to writers. In contrast, and in spite of the opinions of contemporary art critics, Krohg was extremely cautious when referring to himself and to his own generation of visual artists as impressionists (Malmanger I987: 42, 45), and

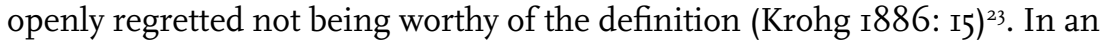
article entitled Den tredie Generation (The Third Generation), published in Verdens Gang on 27 April I889, Krohg explains that while he and his generation of artists, i.e., «den anden Generation» («the second generation»), did consider themselves plein air painters who had been pushing things forward, they still remained in the shadow of the third generation of impressionist painters, at the end of the I880 represented by a solitary Edvard Munch: «Han er Impressionist, endnu vor eneste!» (Krohg I889; «He is an

22 On Manet as a precursor of the impressionists, see also Pouzet-Duzer (2013: 33-I23)

23 Malmanger (I987: 3I) observes that Werenskiold, in I886, and Aubert, in I887, regarded Krohg as the leading Norwegian impressionist painter. 
impressionist, so far our one and only!») ${ }^{24}$.

There seems to be no doubt that the parallel which Krohg subsequently proceeds to draw up between Munch and the unnamed writers of the third generation who, he claimed, were already busy introducing a new literature in Norway, features the concept of impressionism as trait d'union ${ }^{25}$. However, when applied solely to the visual arts, as in the discussion of the impressionist phase in Munch's career, Krohg's understanding of impressionism draws on the formal and technical innovations that formed the basis for perception and execution in painting: the idea of 'the innocent eye', which goes «behind the remembered, theoretically established colour to the real sensation» (Hauser I999: I63); the attempt to present a scene the instant it is being perceived, before the mind triggers interpretation and the organization of data into patterns of meaning; the concentration on the overall impression instead of on unnecessary detail. To Krohg, the impressionist writer is, instead, mainly an artist embodying the 'bohemian stance', capable, like Jæger, of feeling and giving expression to «tidens uro og utilfredshed» (Krohg I886: I4; «the anguish and the restlessness of the age»). In an attempt to clarify Christian Krohg's theory of impressionism, Erik Mørstad underlines what he sees as contradictory in the lecture Om den bildende kunst som led $i$ kulturbevogelsen:

På den ene side betegner impresjonisme i Krohgs terminologi den mest samtidsrelaterte retning i billedkunsten og i kunsten

24 In 1902, Krohg revised this definition of Munch as an impressionist: «Man har sagt, at han [Munch] er Impressionist. Det er i Grunden slet ikke rigtigt» (Krohg I988: 69; «It has been said that he is an impressionist. This is basically incorrect»). However, in I889, Krohg's description of Munch the impressionist is perfectly coherent with the principles of impressionist perception; in a passage which starts out highly reminiscent of the above-quoted paragraph in which Krohg imagines Jæger taking off with his painter's bag and outdoor easel to contribute to the image of the age, he writes: «Han vandrer ikke glad ud med sin Malerkasse med Farverne færdigliggende til at male Luft, Græs eller Solnedgange; han ved ikke, at Luften er blaa, Græsset grønt og Solnedgangen rød, han ved ingenting før han gir sig til at male, han er hvergang forbauset og henrykt over de enkleste, almindeligste Ting, han kjæmper sig hver Gang til det han faar vide, og glemmer det til næste Gang. Han maler - det vil sige - ser paa en anden Maade end de andre Kunstnere. Han ser bare det væsentlige og maler selvføgelig bare det. Derfor er Munchs Billeder i Regelen 'ikke færdige'». (Krohg I889: 42; «He does not set off happily with his painter's equipment and the colours, ready to paint sky, grass or sunsets; he does not know that the sky is blue, the grass green, and the sunset red, he does not know anything before he starts painting, he is always surprised and awestruck in front of the simplest, most common things, what knowledge he obtains each time is obtained with great effort, and he forgets it until the next time. He paints - that is to say - he sees in a way different from other artists. He only sees what is essential and consequently paints only that. That is why Munch's pictures are, as a rule, 'unfinished'»).

25 Although Krohg in this article does not mention the names of the writers belonging to the new generation, Jæger had presented himself as a pioneer in the field of literature a few years earlier. In the foreword to Fra Kristiania-Bohêmen published in I885, Jæger had announced that he was about to introduce a new literature in Norway. Here, as well as in Min Forsvarstale i Høyesterett (My Defence Speech in the Supreme Court), he spoke of his new bohèmeliteratur drawing on Zolaesque naturalism having social reform as its ultimate goal. 
overhodet. Her er det den enkelte kunstners holdning som bestemmer om vedkommende står utenfor eller innenfor impresjonismen. Impresjonisme ser i dette tilfelle ut til å være ensbetydende med det å være moderne, med det at kunsten har sin kilde i inntrykkene fra virkeligheten $i$ vis forstand. [...] På den annen side innholdsbestemmer Krohg impresjonisme-begrepet ut fra rent formale kjennetegn. Dette er en av foredragets sentrale selvmotsigelser, som Krohg ikke avklarer noe nærmere. (Mørstad ı99г: 84)

On the one hand, impressionism, in Krohg's terminology, is of all the currents in the visual arts, and in art in general, the one most closely related to the contemporary scene. Here, it is the attitude of the individual artist that places him outside or inside impressionism. In this case, impressionism seems to be synonymous with being modern, with the fact that art in a certain sense has its roots in the impressions of reality. [...] On the other, Krohg defines impressionism on the basis of purely formal criteria. This is one of the fundamental contradictions in the lecture, one that Krohg does not explain any closer.

When Mørstad in the English summary of his article concludes that «Krohg's basic ideological view is naturalistic, but his method, or way of approach, is impressionist» (I99I: I03), he actually solves the riddle by calling attention to the possibility of combining a social message with a modern form. If the impressionist painters turned away from the tensions and ills of contemporary society and disregarded the motif, the Scandinavian artists of the 'middle way' instead made it a virtue to approach radical naturalistic subject matters with a modern technique, as we will see through the example of painter and writer Helena Westermarck.

\subsection{AUGUST STRINDBERG AND IMPRESSIONISM}

On one occasion August Strindberg identified impressionism as a source of inspiration to his art, in another instance he went as far as to declare himself a literary impressionist. In the foreword to his I888 play Fröken Julie (Miss Julie), Strindberg (I984: III) pointed to the unexpected, audacious framing frequent in impressionist painting as a feature that had determined his choice of an asymmetrical scenography. Karl-Erik Lundevall (I953: 240, 243) has discussed Strindberg's word choice and his preoccupation with the aesthetics of impressionism in this passage of the foreword in terms suggesting that the author intended to apply the principles of pictorial impressionism in the composition of the play. This interpretation was subsequently dismissed by 
Hans Lund (I993: 49), who has rightly called attention to the fact that Strindberg is referring here to stage decoration only. Strindberg's stage directions presented in the foreword involved placing the rear wall and the kitchen table obliquely on stage in order to limit the audience's view to only a fraction of the room where the action was taking place, a method which evidently has its counterpart in the impressionist painters' bold framings of their subjects. In addition to Lund's comment, I would like to draw attention to the fact that the reference to impressionism in a textual passage preoccupied with the play's form and its modernity is indicative of Strindberg's view that impressionism was still, at the time of the composition of Fröken Julie, synonymous with the radical modernity distinguishing the painters on show at the second impressionist exhibition in Paris in the autumn of 1876 , which had awoken the writer's interest during his first visit to the French capital, as we will see.

In the section Människokroppens skönhet och symbolik (Beauty and Symbolism of the Human Body) in the third part of En bla bok (A Blue Book), Strindberg spoke of the character portrayal in his writings and resolved that he had, in the main, created thousands of individuals whose faces were merely caricatures. He explains his technique as similar to that of the impressionist who does not pay attention to details but, in the manner of a behaviourist, focusses on those movements, gestures, and expressions that really reveal the characters' personality: «Sannolikt är jag impressionist som ser på rörelse, gest, uttryck och inte på föremål» (Strindberg 2000: I239; «Most probably I am an impressionist concentrating on movement, gestures, expressions, and not on objects») ${ }^{26}$.

\subsection{1. 'Before': En berättelse från Stockholms skärgård and I vårbrytningen}

On the subject of Strindberg and impressionism there is a 'before' and an 'after'. The dividing line is made up by the author's first encounter with impressionist art, which occurred in 1876 at the second impressionist exhibition hosted by the art merchant Durand-Ruel's Parisian gallery. Impressionism, in Strindberg's literary output preceeding the year 1876 , must therefore be understood without explicit reference to impressionist painting, and either in terms of a prose where speech and dialogue is presented without any expository intrusion of the narrator - i.e., in a manner similar to the method earlier discussed within the discourse on Herman Bang's poetics of impressionism - or, in terms of a writing heightening the reader's awareness of the sensory experience of the scene's observer through frequent textual references to sights, sounds, and smells - a technique still present in the famous opening paragraphs to the novel Röda rummet of I879, as we will see.

According to Göran Söderström, author of the monograph Strindberg

26 Cf., also Lamm i963: 438. 
och bildkonsten (1972; Strindberg and the Visual Arts), Strindberg applied an impressionist narrative technique already in the early I870s, in an unfinished tale known as En berättelse från Stockholms skärgård (A Tale from the Stockholm Archipelago) ${ }^{27}$. Unfortunately, Söderström does not explain what he really encapsulates in the expression «impressionistisk berättarteknik» (Söderström I972: 68; «impressionist narrative technique»)28. Yet, I deem it likely that this evaluation is dependent upon the text's multitude of paratactically ordered impressions separated by dashes, through which the narrator registers the presence of people and animals, smells and sounds, in the initial desciption of an early summer morning in the archipelago (Strindberg I98I: 9-IO). Moreover, in the following pages of the tale, Strindberg lets the dialogues between his characters pour down pell-mell in the text, adopting, in these lines, a language seemingly typical of the single individual ${ }^{29}$.

27 En berättelse från Stockholms skärgård (Strindberg I981: 7-32) introduces the second volume of Strindberg's collected works, containing short stories and sketches written by the author in the early i870s. This initial tale is untitled, unfinished, and undated, though probably composed between I872 and I874 (cf., Strindberg I981: I93, I96-97). It also remained unpublished in Strindberg's lifetime and is known with the above-mentioned title since 1948, when Torsten Eklund first published it (Strindberg 1981: 196).

28 There have been other voices arguing for Strindberg's impressionist style without delving deeper into the question. The famous Swedish literary critic Oscar Levertin, for example, spoke twice in positive terms of the author's fiery writing as an «ingenious impressionism», first on the subject of the volume Ensam (Alone): «Sådan är de stora novellisternas konst, Maupassants och Strindbergs, och i dessa nya 'sagor', hvilka i fråga om glöd och diktarkraft tillhöra det bästa Strindberg på länge skrifvit, griper den oss åter med sin genialiska impressionism» (quoted in Strindberg I994: 287; «Such is the art of the great short story writers, that of Maupassant and Strindberg, and in these new 'fairytales', which as to fervour and poetic force belong to Strindberg's best works in a long time, it strikes us once more with its ingenious impressionism»). The second time he used the expression with reference to Historiska miniatyrer (Historical Miniatures): «August Strindbergs prosa [...] som, äfven där tanke och kunskap lysa med sin frånvaro, dock i oöfverträffad genialisk impressionism ständigt vittnar om den store skriftställaren» (quoted in Strindberg I997: 295; «The prose of August Strindberg [...], with its unbeatable ingenious impressionism, continues to remind us of what great author he is even on occasions when thought and knowledge are absent»).

29 A review by Anders Flodman supports the hypothesis that these aspects of the text may constitute the background for Söderström's characterization of the tale. When the short stories composing I vårbrytningen were published in book form, Flodman reviewed the publication for Aftonbladet and spoke of Strindberg's accumulative technique in the opening lines to Huruledes jag fann Sehlstedt (How I found Sehlstedt) as a form of impressionism (Strindberg I98I: 205). With the adoption of a more regular punctuation and absence of dialogues, these opening lines, describing the same setting as in En berättelse från Stockholms skärgård, come across as an orderly version of the opening paragraphs to the earlier tale. In addition, Helena Estlander, who reviewed the same work for Finsk tidskrift, recognized Strindberg's ability to convey a total impression through his mentioning of a few significant details as a metonymic proceeding (Strindberg I98I: 206; cf. also Lombardi 20I2: 90). Maria Cristina Lombardi, in an article comparing the opening lines of the aforementioned two tales, describes the changes made in the second version as a passage from «un linguaggio allusivo, impressionisticamente connotato» (Lombardi 20I2: 89; «an allusive language with impressionist connotations») to a writing in which «si rileva una tendenza alla denotazione piuttosto che alla metafora» (89; «one detects a tendency towards denotation rather than towards metaphoric language»). 


\subsubsection{Strindberg's encounters with impressionist art}

The event that marks the 'before' and 'after' in Strindberg's engagement with impressionism is, in actual fact, a three-fold story, involving a first reaction, a second reaction, and a retrospective account of these two reactions, 'recollected in tranquillity' some twenty years after their occurrence.

In Paris, during the Inferno-years in the mid-nineties, Strindberg wrote a letter to Paul Gauguin, which came to be published as preface to the catalogue presenting Gauguin's works at an auction held at Hôtel Drouot in February I895, prior to the painter's last trip to Polynesia (Söderström I972: 385 , note 4$)^{30}$. It is in this letter from 1895 that Strindberg, for the second time, describes his first encounters with the art of the impressionists back in 1876 . Twenty years after the second impressionist exhibition, he claims to have observed the paintings on show at Durand-Ruel's gallery, with «une indifférence calme» (Strindberg 200I: 52; «calm indifference»), thus contradicting the bewildered reaction of Strindberg's narrator in the 1876 article written for Dagens Nyheter to inform the Swedish public of the novelties in the French art world (Strindberg 1876 a and $1876 b$ ). Despite all the indifference Strindberg claims to have proved, something in the paintings must, however, have resonated with his curiosity to the point that he decided to pay a second visit to the exhibition the following day, as the writer now reveals to Gauguin in the letter. According to the 1895 testimony, the second time Strindberg - almost malgré soi - set his eyes on the «toiles très merveilleuses» (Strindberg 200I: 52; «very wonderful canvasses») displayed at the gallery, he discovered something that indisputably struck him:

le lendemain je revins, sans trop savoir comment, et je découvris 'quelque chose' dans ces bizarres manifestations. Je vis le grouillement de la foule sur un embarcadère, mais je ne vis pas la foule même, je vis la course d'un train rapide [...], le mouvement des roues dans la rue, d'affreux portraits de personnes toutes laides qui n'avaient pu poser tranquillement. Saisi par ces toiles extraordinaires, j'envoyai à un journal de mon pays une corres-

30 The letter is known as Lettre à Gauguin (in Swedish as Till Paul Gauguin or Brev till Gauguin) and is dated I February I895. In combination with Gauguin's answer, Strindberg's letter was first published in the French review L'Éclair on I5 and I6 February I895 and subsequently adopted as preface to the catalogue for Gauguin's exhibition, which opened on I8 February (cf., Usselmann I982: 156). The letter is now included in Samlade Verk 34: Vivisektioner II (Strindberg 20I0b: 25I-54), https//:litteraturbanken.se/forfattare/StrindbergA/ titlar/Vivisektioner2/sida/25I/etext; accessed 22 January 20I8. Brev till Gauguin, William Molard's first Swedish translation of this letter, is published in Samlade skrifter 54 (Strindberg I920: 325-29) and available online at www.runeberg.org/strindbg/eftersl/0325.html; accessed 7 February 20I8. Another Swedish translation (Strindberg 20I0a) by Lars Strömberg is online at https://litteraturbanken.se/forfattare/StrindbergA/titlar/Vivisektioner2/sida /II5/etext; accessed 7 February 2018. 
pondance dans laquelle j'avais essayé de traduire les sensations que je croyais que les impressionnistes avaient voulu rendre [...]. (Strindberg 200I: 52)

I returned the following day, without really knowing why, and discovered 'something' in these bizarre manifestations. I saw a swarm of people on a pier, but I did not distinguish the very crowd; I saw the racing of a fast train [...], the movements of wheels in the street, horrible portraits of ugly people, who had not been able to sit still while posing. Taken with these remarkable canvasses I wrote an article for a newspaper in my home country, in which I tried to render the impressions which I thought that the impressionists had tried to convey $[\ldots]$.

The article mentioned in the excerpt quoted above was published in two parts in Dagens Nyheter on 30 November and 9 December I876 with the title Från Café de l'Ermitage till Marly-le-Roi och så vidare (Strindberg I876a and I876b; From Café de l'Ermitage till Marly-le-Roi and so on) ${ }^{3 \mathrm{I}}$. Considering that Strindberg's disconcerted narrator describes the six impressionist landscapes seen at Durand-Ruel's in the company of a well-informed guide as «tunna, rödblåa, eländiga, alla lika» (Strindberg I876a; «thin, reddish blue, miserable, all the same») - and closes the second part of the article with the words «de långa café-resonnemangen [...], slutade med att besökaren sett för litet och ännu inte hunnit bli van vid att betrakta den franska konsten med franska ögon» ${ }^{32}$ (Strindberg I876b; «the long discussions at the café [...], ended with the conclusion that the visitor had not seen enough and had not yet grown used to observing the French art with French eyes») - it is evident that the author, when reiterating the two visits at the impressionist exhibition twenty years later, has at last grown used to observing impressionist art, and has now certainly seen enough to deliver an accurate account of the aims of the movement.

In 1876 , Strindberg noted of the «miserable» novelties exhibited that they rendered not the scene but the artist's subjective impression of the scene, including physical obstacles, such as the steam from a train, impeding a clear view $^{33}$. In I895, when evoking instead the second day at the exhibition, his wording is, as we have seen, on the one hand unquestionably more favourable - «nous vîmes des toiles très merveilleuses» (Strindberg 200I; 52; «we saw very wonderful canvasses»), «saisi par ces toiles extraordinaires» (Ibidem;

3I The article is also available online at https://itteraturbanken.se/\#!/forfattare/ StrindbergA/titlar/KulturhistoriskaStudier/sida/III/etext; accessed 22 January 2018.

32 Italics in the original.

33 An observation that Strindberg had already put forward as early as I874 in his article on modern Swedish landscape painting, Vårt nyaste landskapsmåleri (Our Latest Landscape Art), Usselmann I982: 155 . 
«taken with these remarkable canvasses») - and, on the other, the writer now does his best to put his finger on that «something», which he claims to have discovered when returning to the exhibition. This is done by revisiting the very same details that baffled the narrator in the 1876 articles and reflecting on them with the hindsight of twenty years: the rendering of «en folkhops hvimmel på en ångbåtsbrygga» (Strindberg I876a: «the hustling of a crowd on a pier»), that had seemed perplexing to the observer in 1876 , is explained in the letter from 1895 in terms suggesting a new understanding of the metonymic mode that forms the basis for the impressionist perception. In the letter to Gauguin, Strindberg proves able to explain that what he really saw was «le grouillement de la foule», not «la foule même» - a swarm of people, but not the single individuals. Through the wording in the 1895 letter, Strindberg further demonstrates to have fully realized that the train crossing another impressionist landscape on show, was indeed not a painting representing a train but the 'racing' of a train (2001: 52; «la course d'un train»), that the impressionists did not wish to render wheels but «le mouvement des roues», i.e., the impression of movement and simultaneity, more than the objects themselves - a principle that, he gathers, also went for the art of portraiture.

As mentioned earlier, what primarily attracted the onlooker in Strindberg's article of 1876 , was the idea of a group of progressive artists refusing to paint according to the official taste of the Salon - «Det fanns sålunda en åsikt, ett parti, och ett sådant som icke målade för salongen; dem måste jag se!» (Strindberg I876a; «so there was an opinion, a party, one that did not paint for the Salon; I had to take a look at them!») - though the result was, in his eyes, less convincing. It is also interesting that when conveying the narrator's impressions of a Sisley canvas, Strindberg should recur to grammatical categories in order to make himself clear, as if painterly impressionism, to him, was best understood through a 'reverse' interart analogy, i.e., by referring to the art of narration, the one that he himself mastered the best: «skall jag våga ett försök att beskriva Sisleys [sic]! Det kan endast ske på följande sätt - märk noga temporalföljden, ty man målar - otroligt att säga - en handling i presens, perfektum, och futurum, indicativus och conjunctivus» (Strindberg I876a; «shall I attempt to describe Sisley! It can only be done in the following manner - pay careful attention to the temporal sequence, as an action - strange to say - is painted in the present tense, in the perfect tense, in the future tense, in the indicative and in the subjunctive»).

Not impressed by Sisley's pale colour scale, diagnosed as «albinism» (Strindberg I876a), this attentive, though sceptical, observer decides to find out for himself whether French landscapes do correspond to the paintings on show at Durand-Ruel's. After a short stop at Café de l'Ermitage, he sets out for the countryside at Marly-le-Roi with the spirit of an empiricist wanting to verify the degree of realism in impressionist landscape painting: «jag 
beslöt att företaga en besiktningsresa ut i den franska naturen och se efter om det rörde sig, om det var ljusare än i Tyskland och om impressionisterna hade litet rätt» (Strindberg I897a, italics in the original; «I decided to go on an exploratory journey into the French nature to verify whether it really moved, whether it was lighter than in Germany and whether the impressionists somehow were right"). In the small village of Marly, the narrator meets up with a Swedish painter who has adopted the same bloodless, reddish blue hues as the impressionists exhibited ${ }^{34}$. The narrator's conclusion is that the outcome of studies abroad is a universal foreignness: not only is the painter foreign to his new environment but he will, in the end, also become foreign to his home country, unable to adapt painterly techniques learned abroad to his local conditions. He resolves:

att det vore klokt icke bortkasta en med mångårig möda förvärvad färdighet för en ny av tvivelaktigt gagn, att de skulle pröva allt och behålla vad gott var, och icke oprövat taga allt för gott, därför att det var nytt, att det var utländskt, att det var franskt! (Strindberg 1876b)

that it would be wise not to discard an ability gained through years of hard work in favour of a new, the value of which is doubtful, that they [the Swedish painters] would experiment with and hold on to what was good, without taking to anything just because it was new, because it was foreign, because it was French, without first trying it out.

In conclusion, with regard to Strindberg's reactions to impressionist painting, most scholars interested in the topic have, with contradictory results, attempted to evaluate the degree of appraisal present in the opinions that the author expressed in his writings on the second impressionist exhibition in Paris. Lundevall, for example, claims that the Swedish writer was no admirer of the impressionists «även om han var mer gripen [...] än han ville erkänna» (Lundevall I953: 239; «although he was more taken [...] than he was willing to admit»), Söderström (I972: 59), instead, claims to have detected a positive attitude to impressionism in Strindberg's wordings on the subject. Henri Usselmann summarizes the question in an article entitled Strindberg et l'impressionnisme:

Depuis plusieurs décennies, certains spécialistes affirment que Strindberg haïssait l'impressionnisme, tandis que d'autres s'appliquent consciencieusement à chercher l'influence de l'impres-

34 According to Göran Söderström (1972: 60), Strindberg met with Per Ekström in Marlyle-Roi. 
sionnisme dans son oeuvre picturale, littéraire et même photographique. (Usselmann I982: 153$)^{35}$

For several decades certain specialists have been affirming that Strindberg hated impressionism, while others have put a great effort into the search for the impact of impressionism on his painterly, literary, and even photographic work.

It seems to me that registering Strindberg's awareness of impressionist art - his early insight into the movement, and his later revision of this vision, which deepened his understanding - is more meaningful than assessing the writer's appreciation or lack thereof. The trailblazingly modern aspects of the impressionist school sparked an interest for the movement to the point that Strindberg would indicate its unconventional aesthetics as a model for the shaping of perspective plane in the stage directions to Fröken Julie.

\subsection{3. 'After': Röda rummet, I havsbandet, and Hemsöborna}

The stylistic qualities of the opening paragraphs to the novel Röda rummet of I879, frequently quoted as a masterly example of Strindberg's art of narration, have also been discussed in relation to the author's engagement with impressionism ${ }^{36}$. The question was brought up in the I920s, in an article by Ruben G:son Berg entitled Inledningen till Röda rummet (Berg I92I; The Opening to Röda rummet) and by Göran Lindblad in the monograph August Strindberg som berättare (Lindblad i924; The Narrator August Strindberg) ${ }^{37}$. Both scholars associated Röda rummet's overture to novelties in the visual arts brought about by the impressionist plein air painting of the I87os; Berg by simply defining it as an «impressionistisk skildring» (I92I; «an impressionist description»), Lindblad instead by specifying that «det är impressionism, litterärt plein-air-måleri» (I924: 73-74; «it is impressionism, literary plein air-painting»), further explained as a writing communicating «vad den franska skolan eftersträvade, den levande, obearbetade ögonblicksbilden, l'impression vierge» (74: «what the French school strived for, the vivid, unprocessed instantaneous image, l'impression vierge»).

35 In this article, Usselmann in fact examines Strindberg's presumed engagement with impressionism not only as a writer but also as a painter and a photographer.

36 See, e.g., Berendsohn i964.

37 Sten Linder spoke of «den impressionistiska verklighetsskildringen» (Linder 1936: 38; «the impressionist description of reality») in Röda rummet, seemingly indicating the fragmention that both composition and characters undergo in the novel. Karl-Erik Lundevall (I953: 243) summarily mentions Strindberg's choice of uncommon reporting verbs, and the adoption of reported speech without the narrator's intervention as characteristics present in the prose of Röda rummet, which in his opinion are relevant to literary impressionism. 
Subsequently, however, Lindblad also indicated a different pictorial model at work in the novel. According to the scholar (Lindblad i924: 77-78), at the root of the novel's more bucolic scenes, set outdoors, is Carl Larsson's visual lexicon, although Strindberg exits Larsson's gardenscapes to confront the view of the city. On the subject of the scenes set in the open air at Lill-Jans, Lindblad comments that these descriptions, as to atmosphere and setting, are «något mitt emellan Carl Larssons sagoteckningar och hans målningar från Grez» (77; «something in between Carl Larsson's fairytale illustrations and his paintings from Grez»).

As regards Strindberg and Larsson, Gotthard Johansson added some pertinent precisions in I949. In an article entitled Strindberg och konsten (Johansson I949; Strindberg and Art) he argued for the correctness in establishing parallels between the opening paragraphs in Röda rummet and Carl Larsson's watercolours of the early I880s painted in Grez-sur-Loing, as well as for a general affinity between the aesthetics of Strindberg's textual landscapes and the nineteenth century fashion of painting outdoors, but considered the parallel to impressionism redundant: «det är friluftsmåleri men inte impressionism» (Johansson I949: 20, italics in the original; «it is plein air-painting, not impressionism»). Johansson's point is the independence of Strindberg's stylistics, which built on a highly individual descriptive technique that the author had already started to develop in the early i87os, one that should not be tied to a specific school of landscape painting:

Att kalla Strindbergs egen litterära teknik, sådan den framträder i de första skärgårdsnovellernas eller Röda rummets naturskildring, för impressionism är [...] riktigt, endast om man tar ordet $\mathrm{i}$ en mycket allmän betydelse. Med all sin luftighet skiljer sig detta litterära friluftsmåleri [...] från den verkliga impressionismen framför allt genom sin detaljskärpa, sin berättarlust, sitt sakliga intresse för verkligheten. I det impressionistiska måleriet utplånas detaljen - som Strindberg redan vid sitt första möte med detta måleri visade sig så riktigt uppfatta - för att uppgå i helhetsintrycket, bli en färgfläck i bilden. (Johansson I949: 25-26)

To speak of Strindberg's own literary technique, the way it appears in his first short stories set in the archipelago or in the descriptions of nature in Röda rummet as impressionism, is correct only if the term is used in an extremely general meaning. With its airy atmosphere this literary plein air painting is distinguished [...] from genuine impressionism above all through its focus on details, its accent on the anecdotal, its objective interest for reality. Impressionist painting disregards details - just as Strindberg quite correctly had realized in his first encounter 
with this art - the detail disappears in the total impression and becomes a colour dot in the picture.

The only literary work that, according to Johansson, reveals an influence of impressionst aesthetics on Strindberg's prose is the novel I havsbandet (By the Open Sea) from I890, which the critic describes as «ett koloristiskt kraftprov av en med- eller omedveten lärjunge till de stora impressionistiska mästarna» (27; «as to the handling of colour a brilliant performace by a conscious or inconscious disciple of the great impressionist masters»). He also attempts to establish analogies between descriptions of interiors in the novel and impressionist pictorial techniques ${ }^{3}$.

Building on Sven Møller Kristensen's first studies on J.P. Jacobsen's impressionism (Møller Kristensen I938), Bengt Kinnander has examined the question of impressionism in Strindberg's prose from a different point of view. In his essay, Ordstudier i Strindbergs prosa (Kinnander I949; Studies in Strindberg's Prose Vocabulary), a passage from Hemsöborna (The People of Hemsö), focussing on the gradual perception of a lantern by moving from the narrator's initial, vague awareness of a distant source of light to his gradual distinguishing of this lantern, and subsequent recognition of the holder's face, serves Kinnander in his attempt to prove Strindberg's adherence to the aesthetic programme of impressionism. The scholar compares this scene to the opening paragraph in J.P. Jacobsen's Mogens depicting a gradual rainfall, a descriptive mode which Sven Møller Kristensen labels as 'phenomenological perception'. When the rendering of a scene is not arranged into a logical sequence but guided by the reporting of sensorial impressions in the very same order in which these are supposedly perceived by the observer, Kinnander finds it apt to define Strindberg's prose as literary impressionism. He concludes: «vi ha här [...] ett 'impressionistiskt' framställningssätt, betingat av situationen» (Kinnander 1939: 55; «what we have here is [...] an 'impressionist' representation, determined by the situation»). Kinnander, however, observes that the narrator's passivity, which according to Møller Kristensen is characteristic of the impressionist reporter, does not become Strindberg's narrator, who «argumenterar även när han berättar och beskriver» (56; «argues even when narrating and describing»). In addition, Kinnander (Ibidem) also observes cases of Møller Kristensen's idea of an impressionist 'metonymical mode' in Röda rummet and I vårbrytningen, which are likened to the Danish scholar's conception of literary impressionism. On the subject of Hemsöborna, it is interesting that Gustaf af Geijerstam, who, as we will shortly see, was one of the few Swedish literary critics to consider literary impressionism a province of the critics, should be

38 Eszter Szcalzer has also worked on analogies between Strindberg's textual descriptions in Samvetskval (Pangs of Conscience) and canvasses by the impressionist masters. I would like to thank her for letting me read her unpublished contribution to The Nineteenth International Strindberg Conference, Strindberg across Borders, held in Rome on 5-7 June 2014. 
the one among Strindberg's contemporary critics to recognize impressionist traits in this novel. In a review published in Nya Pressen on 22 January I888 he wrote:

I allmänhet skildrar Strindberg naturen som impressionist. Han målar ej lugnt upp ett landskap med alla dess konturer och skiftningar, utan han förutsätter liksom, att läsaren vet, hur det ser ut ändå. Så ger han några bilder, hvilka han erinrar sig, raskt och energiskt, och fantasin hos läsaren får fylla i resten. (qtd. in Strindberg 2012: 198)

Generally, Strindberg represents nature in the manner of an impressionist. He does not calmly depict a landscape with all its outlines and nuances; by contrast, he takes for granted that the reader is in any case familiar with the subject. So, he offers a few images, the ones that come to his memory, swiftly and energically, leaving the rest to the readers' imagination.

This outline of critical contributions concerned with Strindberg's presumed impressionism has revealed: (I) that the works seen as indicative of an engagement with literary impressionism in Strindberg's production are the early short stories set in the archipelago (En berättelse från Stockholms skärgård, I vårbrytningen) as well as Röda rummet, I havsbandet, and Hemsöborna; (2) that most literary critics resorting to the term impressionism on the subject of Strindberg's prose blandly employ it to indicate fragmentation, the use of colours, plein air prose (but not necessarily with references to the specificities of impressionist plein air painting). In one rare, in-depth, examination of single passages in Strindberg's writing (Kinnander I939), the definition is strongly influenced by Møller Kristensen's (I938) interpretation of literary impressionism as a technique employing metonymical description and uncorrected, phenomenological description, an aspect that will be more profoundly discussed in part II of this study. 



\section{$5 \cdot$ \\ LITERARY IMPRESSIONISM AND FINLAND. A CRITICAL DIGEST}

The aim of the following paragraphs is to bring into focus the concept of literary impressionism mainly within the context of Finland-Swedish literature. The attempt is to show to what extent the critical debate in Finland-Swedish reviews and newspapers demonstrated an awareness of the idea of impressionism in literary writing and what aspects of the phenomenon this understanding encapsulated. This has been done by undertaking a survey of the use of the term in the literary criticism present in the review Finsk tidskrift and in the Finnish newspapers published in Swedish from approximately 1870 to 1910 . By examining the critical attitudes to literary impressionism in Finland, I hope to add a piece to the greater Scandinavian mosaic that is still being shaped by the contributions of scholars who have tried to clarify the impact of impressionism on Danish, Norwegian and, even if only partly, Swedish literature. No effort to assess the role of impressionism in the Swedish literature of Finland has so far, to my knowledge, been made.

The choice of fixing the term in a historical context, that of the 'age of impressionism', in this survey, does not deny the fact that impressionism can also be seen as an ahistorical phenomenon present long before and long after the high point of the impressionist pictorial movement. Glimpses of a similar approach are evident in the journalism taken into account and is also present (at times with what seems to be a provocative intent) within the larger context of Scandinavian literary criticism ${ }^{2}$. The choice of anchoring

I Investigation of literary criticism in the Finnish newspapers has been done with the help of the digital collections of the Historical Newspaper Library, available at http://digi.lib.helsinki.fi/sanomalehti/search. Accessed 7 February 20I8..

2 On impressionism as an ahistorical impulse within Scandinavian literature there have been voices arguing that C.M. Bellman (I740-95) should be seen as a forerunner of impressionism. To remain within the sources that have been investigated for this study, an anon- 
the investigation to the end of the century is dependent upon the wish to discover whether writers and critics in Finland shared their Scandinavian colleagues' awareness of a concept peculiar to their days. In the previous pages we have taken a look at the debate that had proved rather vivacious in Norway and in Denmark and, as we will see from the survey, there were also Swedish voices in the I88os arguing in favour of an impressionist break-up with the academic tradition. Reports from the Scandinavian literary scene were, in fact, frequent in the Finnish press at the end of the nineteenth century; journalists followed the scandal aroused by Christian Krohg's novel Albertine in Norway and reported on the foundation and the proceedings of Krohg and Hans Jæger's review Impressionisten, on the pages of which their singular 'bohemian' interpretation of literary impressionism as subjective naturalism was proclaimed ${ }^{3}$. The Scandinavian tour of Herman Bang, who openly expressed his dissatisfaction with the shortcomings of naturalism, reached Helsinki and Turku in 1885 and was covered by the press ${ }^{4}$. In the material taken into consideration, there is one example of a journalist reporting from Russia on a lecture given by Pyotr Gneditch on the subject of impressionism in literatures. Not surprisingly, however, it was mainly through the mediation of Sweden that the idea of an impressionist break with tradition was introduced to the literary circles in Swedish-speaking Finland. Let us turn to some of the protagonists.

ymous author writing for the Finnish newspaper Hufvudstadsbladet (4 July I902) speaks of Bellman's «underbara impressionism, som i poesin upptäckte friluftsmåleriet mer än hundra år tidigareänvårkonsts opponenter!» («wonderfulimpressionism, thatdiscovered pleinair-painting in poetry more than a hundred years before the opponents in our art!»). In a review of Ola Hansson's Kåserier i mystik (Hufvudstadsbladet I2 December I897; Mystic Causeries), the signature 'O-o' mentions Hansson's discussion of different artistic suggestions in which he claims that the «impressionist-suggestion» was the basis for the writings of Kleist, Sterne, Pie, Almqvist, and Stagnelius ('O-o’ I897). See also Finn S. Larsen's quibbling article (Larsen I973) about impressionism and Leonora Christina's Jammers Minde (Memories of Woe). The same situation is somehow present in art criticism. Leif Østby suggests that we consider the authors of petroglyphs as the earliest impressionists as their art is «øyets, ikke tankens» (I966: I4; «of the eye, not of the mind»).

3 See the anonymous entries Från Skandinavien, Nya Pressen 29 December ı886; Bref från Kristiania, Finland 5 January I887 and De Skandinaviska länderna 24 April I887; an untitled notice in Åbo Tidning I4 February I894. Under the headline Från Skandinavien, Nya Pressen 29 January I887, the bohemian movement around Hans Jæger and Christian Krohg was described as «den impressionistiska vänstern» («the impressionist left wing»). In the history of art, the impressionists are often seen as 'the extreme left' in relation to the academic painters.

4 Arne Toftegaard Pedersen has mapped the press reports on Bang's tour of Finland (2002: 44-45). He also mentions Torben Nielsen's essay På tourné med Herman Bang (Nielsen I984; On Tour with Herman Bang) as a text offering «en livlig beskrivelse af Bangs møde med Finland» (44; «a lively description of Bang's encounter with Finland»).

5 See Literära och vetenskapliga samfund i S:t Petersburg: Bref till H:fors Dagblad (Literary and Scientific Associations in St. Petersburg), Hufvudstadsbladet 3 March I889. The work taken into account by Gneditch was Zola's novel La Terre (The Earth). In a «letter from Russia», published in Tammerfors Nyheter in I9I0, the signature 'Spectator' gave a short characteristic of Chekhov's impressionism with the following words: «Den färgar allt i författarens egen stämning (impressionism)» («It colours everything with the author's personal mood [impressionism]»). 
One of the Swedish writers capable of phrasing the impressionist experience was Gustaf af Geijerstam (1858-1909) $)^{6}$. The use of the concept of impressionism in his literary criticism has not, to my knowledge, previously been examined. As Hans Lund points out (I993: 49), the Swedish literary historian Nils Erdman labelled Gustaf af Geijerstam's own writing «impressionist in style», in his study Modern realism (Erdman I884: I04), in order to highlight Geijerstam's manner of transmitting «det ögonblickliga intrycket» («the instantaneous impression») as well as his use of the point of view (Ibidem). Lund also mentions Geijerstam's attack in Ur samtiden (I883; From the Contemporary Age) on the Norwegian writer Kielland, and his dismissal of any work of literature conceived under the wing of Brandes's slogan in favour of an opposing group of writers such as Bang, Turgenev, Zola, Daudet, and the Goncourt brothers (1993: 52). Geijerstam's condemnation seems, in spirit, closely related to Hans Jæger's criticism of the naturalistic writers put forward on the pages of Impressionisten a few years later and is certainly part of a general wave of dissatisfaction with what was seen as the insufficiency of naturalism. Lund, however, also states as a conclusion that Geijerstam did not apply the expression 'literary impressionism': «Geijerstam använder emellertid inte själv termen litterär impressionism» (Lund I993: 52; «Geijerstam himself, however, does not make use of the term literary impressionism»).

Geijerstam's literary reviews in the Finnish press of the mid-eighties however contradict Lund's statement and offer a few examples of the critic's use and interpretation of the term. Not only does Geijerstam display a sensible understanding of certain essential aspects of what is commonly thought of as the literary methods of impressionism, but he also reveals his appreciation of what he sees as impressionist tendencies in Georg Nordensvan's and August Strindberg's writings from this period. Geijerstam raises some interesting points that link his reading of literary impressionism to specific key issues in the critical discussion of the term: not only to the long-established, universal, question of the relationship between literature and painting, but also to the Scandinavian - specifically Norwegian and 'bohemian' - acceptance of literary impressionism as a concept general enough to accommodate subjective, confessional, writing. Let us take a look at Geijerstam's first

6 Gustaf af Geijerstam was one of the founders of the student association Verdandi in Sweden. He worked for the Swedish newspapers Aftonbladet and Dagens Nyheter and reported from the Swedish cultural scene in Breffrän Sverige (Letters from Sweden) for the Finnish review Finsk tidskrift in the years when C.G. Estlander was its editor-in-chief (I876-86). Geijerstam also worked as a literary counselor for the publishing house Gernandt in the years 1897-I902. His debut as a writer dates back to I882, when Gråkallt (Greycold), his first collection of short stories, was published. As a writer, Geijerstam was first influenced by Zola and French naturalism, later he declared his admiration for Dostoyevsky and Russian realism. He translated Bang's Fæedra into Swedish in I883. 
article that appeared in I884, one year after Henrik Jæger had introduced the term in Scandinavian literary criticism.

In the early I880s, Geijerstam worked as a correspondent for Nya Pressen, a paper encouraging an explicitly modern approach to art and literature (Ekelund 1969: 379). On 3 November I884, NYa Pressen published Geijerstam's review of a collection of short stories written by the Swedish art critic Georg Nordensvan7. In the article entitled Skuggspel, tidsbilder af Georg Nordensvan (Shadowplay, Images of an Era by Georg Nordensvan), Geijerstam accounts for Nordensvan's literary method which, according to the reviewer, owes much to impressionist painting: «impressionism, hvilket ju som bekant eljes egentligen betecknar en särskild riktning inom måleriet är just rätta ordet för att beteckna det skriftsätt, som Nordensvan här användt» (Geijerstam I884; «impressionism, which, as is known, really refers to a particular current in painting, is the correct word with which to define the literary mode that Nordensvan here has made use of»). Geijerstam subsequently proceeds to explain his personal understanding of pictorial impressionism. His insight into a movement that in the I880 had finally started to encounter the favour of Swedish art critics (Hedström 2002: 64) captures two concerns central to the theoretical discussion surrounding impressionist representation since its very beginnings: the question of the metonymic mode (the ability to render, with a few essential details only, an entire landscape or a whole object) and the idea of the untutored 'innocent eye', that is, the representation of an object as it is seen rather than as it is known to be ${ }^{8}$. Geijerstam puts forward two examples of subjects familiar to impressionist painting: an object in motion, a moving wheel (quite different from picture book illustrations of a wheel drawn spoke by spoke); a street scene as seen from the fifth floor of a building (a rendering that implies describing people and objects exactly the way they appear from above and at a great distance, not as they would when seen from a street level perspective). These few lines, Geijerstam claims, are sufficient to shed light on the parallel between impressionist painting and Nordensvan's literary technique, which the critic praises because of its

glimtvis uppfattade naturscenier [sic], snabba rumsinteriörer, samtal, der jämt så mycket är uppfångadt och bibehållet, som

7 In one of Georg Nordensvan's articles dedicated to impressionist painting (Nordensvan I883c) it is evident that the author shared the early conoisseurs' admiration of impressionist landscapes but also their doubts when confronted with the juxtaposition of colours. In part III of the present work I will examine Nordensvan's art criticism in relation to his prose fiction.

8 The notion of 'the innocent eye' acquired fame through the use Ruskin made of it in Elements of Drawing, first published in I857 (Ruskin 1997), but stems from a long tradition in the discourse of artistic theory. Pouzet-Duzer (2008: 15, 2I7) attributes the invention of a natural and primitive «œil impressionniste» as opposed to the «œil académique», with its imposed rules of perception, to Jules Laforgue (Laforgue I902-03). An English translation of Laforgue's essay (Laforgue 1956) can be found online at https://www.msu.edu/course/ha/240/laforque. htm. Accessed 7 February 2018. 
behöfs, för att man skall kunna förstå dessa sammanträngda lifsskildringar, der de allmänna dragen tagits med ögonblicksfotografi, och detaljerna suddats bort. (Geijerstam I884)

natural scenery caught in glimpses, swift room interiors, conversations, from which just as much is reported and maintained as is necessary to make the reader understand these concentrated life stories of which the general traits have been captured through instantaneous photography, and all details wiped out.

Geijerstam is thus more concerned with a comparison between the two sister arts than with the question of the frontiers between naturalism and impressionism in the history of literature, a topic that, on the subject of literary impressionism, occupied Norwegian writers such as Jæger and Krohg, as we have seen. He concludes by maintaining that Nordensvan has «the sensibility of an impressionist», an excellent technical ability that contributes to the success of the book, and also lists the fortunate moments when his impressionist talent best shines through. However, if Nordensvan's book formally is seen as a «flyktig framställning af flyktiga drag» («a fleeting representation of fleeting features»), this aspect of the text leads to a certain superficial distance, of which Geijerstam does not approve, between the author and his subject matter, characterized, in the subtitle, as «tidsbilder» («images of an era»).

The concluding, unfavourable, comment leads to the next example. Almost two years later, Geijerstam reviewed Jäsningstid (Time of Ferment), the second volume of August Strindberg's autobiographical novel Tjänstekvinnans son (The Son of a Servant), for the same paper (Geijerstam I886). In this article, Geijerstam sets out to defend Strindberg's intentions with the novel, that is, «det smärtsamma och upprifvande arbetet att lägga fram för allmänheten hela sitt lif» (Geijerstam ı886; «the painful and excruciating labour of publicly uncovering one's entire life»). If Strindberg chose to write «utan hänsyn» («with no regard») for «sina egna privata förhållanden» («his own private circumstances»), his unveiling of personal and «intima skildringar» («intimate accounts») is, according to Geijerstam, done with a purpose, namely one that «bidrager att kasta ljus öfver och lära oss förstå den tid som skildras och den författare, som skrifvit dem» («contributes to shining a light on and making us come to terms with the epoch that is being described and with the man behind these descriptions»).

His words seem to endorse the artistic ground on which Hans Jæger's literary programme stood. As we have seen, Jæger had outlined his literary theory in the foreword to Fra Kristiania-Bohêmen published in 1885, and further developed his initiative, e.g., in the article entitled Vor Literatur. Geijerstam thus both seems to echo and to foreshadow Jæger's arguments 
and Krohg's reading of the bohemian's autobiographical project in impressionist terms: 'writing the self' is not only a method of self-analysis but, in Krohg's opinion, primarily a means of allowing the contemporary readership to come to terms with its own epoch by piecing together extreme and intimate portraits of the most representative children of their time (Krohg I995: 84). Although Geijerstam's criticism seems to subscribe to what was to become the first commandment of the Norwegian Bohème «Du skal skrive dit liv» («You shall write your own life») ${ }^{9}$, in order to anticipate the end of an era that had seen art and literature as a forum for debating problems, he does not, like the bohemians, adapt the concept of impressionism to accommodate confessional literature. As he goes on to define Strindberg as an impressionist, he grounds his opinion foremost in stylistic parameters. «Som författare» («as a writer»), Geijerstam argues, Strindberg is an impressionist in the same metonymic mode as Nordensvan: in just a few swift and essential lines, he presents the reader with a vivid scene. Geijerstam might not make a straightforward case for identifying subjective writing with impressionism, but he does show his appreciation for a novel that (due to the autobiographical genre to which it belongs) shortens the distance between author and subject matter - a relationship that the critic had found fragile in Nordensvan's collection of short stories. Geijerstam does not hesitate to present himself as an apostle of the impressionist mode in art and in literature that Strindberg, in his eyes, represents: «Oförståndet tadlar här liksom inom måleriet detta förfaringssätt och kallar det 'skef' [sic]. Försök att 'skefva' på det sättet! Notabene så att det blir någon effekt» («Ignorance disregards here [in the field of literature] as well as in painting this practice and calls it 'distorted'. Try to 'distort' in this manner! Nota bene, in order to achieve an effect»).

\subsection{IMPRESSIONISM IN THE AIR}

Geijerstam's return to the idea of 'the innocent eye' in order to explain the impressionist technique is yet another addition to the wide variety of interpretations of a concept that had made its way into Scandinavian literature and literary criticism starting from I883 and then swept through the decade as a literary mode reduced to different formulas. Such formulas include, as we have begun to see, concentrating on the total impression rather than on the mass of details (Henrik Jæger); the fleeting moment of a reality that is a 'becoming', not a fixed 'state' (Nils Erdman); the subjective impression rather than an attempt at an objective look (Christian Krohg). When the

9 The nine commandments of the Bohème were published in Impressionisten 8, February I889. Jæger anticipated the first commandment with his statement, published on the nr. 7 issue, that the new literature which was in the making by the modern youth of Kristiania would be nothing more and nothing less than 'writing one's own life'. See Storskog 2003. 
phenomenon was discussed in the Finnish press in the second half of the I88os, impressionism, mediated through the literature of Sweden, came to be pictured as a new school that had made a definite break with academic tradition and Brandesian naturalism. On 3 July i886, Östra Finland published an article entitled Några litterära förhållanden (Some Literary Circumstances), in which an anonymous journalist aimed to describe opinions and trends in contemporary Swedish literature. In Sweden, the article states, a number of young talented people (artists, poets, and writers) has broken with the academic tradition, its rules and ideals, and founded a new literary school that has «ställt upp impressionismen och naturalismen som nya gudar» («established impressionism and naturalism as new gods»). The author of the article does not mention any names, but suggests that the Swedish-speaking writers in Finland should look to the success of the new Swedish school as a model. «Den något ensidiga problemdiktningen och naturalismen» («the somewhat monothematic problem-literature and naturalism») found in Ibsen and his imitators are seen as losing ground. The Swedish readers now desire a new poetry that warms the heart, as well as 'moral' books. Although the Finnish situation lags behind these developments, the article notes that a radical new trend, impressionism, is in the air, but has yet to defeat the local academic tradition:

\begin{abstract}
Man önskar något, som åter kan tala till känslan, likasom de gamle gjorde, men i den form, som detta nu åstundas, har det ännu ej kommit. De flesta göra ej klart för sig detta förhållande, men det ligger tydligen i luften samt observeras allrabäst inom teatern och målarkonsten. Endast det allrabästa och det mer moderata i den moderna genren slår an. Impressionismen vinner ingen framgång. Akademin är ej ännu besegrad. (I886 Några litterära)
\end{abstract}

We are longing for something capable of talking to the senses once again, just like it was done in the old days, but the form that we are yearning for is yet to come. Most of us are not aware of it happening, but it is clearly in the air and can best be observed within drama and painting. Only the very best and the more moderate in the modern genre are being appreciated. Impressionism is not winning any favours. The academy is yet to be defeated.

When the i88os gave way to the I89os, the Finnish critics could look back at the previous decade and observe the changes that had taken place in naturalism. On 6 December I89I, Hufvudstadsbladet reported on the annual reunion of the newly founded (1885) Svenska Litteratursällskapet (The 
Swedish Literary Society), opened by chairman C.G. Estlander's speech, which was published the same day in Nya Pressen, the journal of which Estlander was co-founder ${ }^{\mathrm{IO}}$. In the speech (I891 Svenska litteratursällskapets möte), Estlander illustrates his view of the development that Finnish literature had undergone in the nineteenth century, expressing his, by no means original, opinion that the literature in Finland had fallen into an abyss after the great era of the national poet J.L. Runeberg, from which it would not arise until the I88os. Estlander sees the I880s as an opening-up of a new era with a new atmosphere and a different outlook dependent on naturalism and impressionism:

Tidsstämningen är ny, åskådningen likaså. Werklighet, natursanning blir den nya lösen och man fordrar af skalden att han återgifver denna werklighet omedelbart. Naturalismen och impressionismen ha funnit väg till oss och eröfrat dikten. [...] Wid bedömandet af den nya riktningen bör man komma ihåg, att om idéerna äro ewiga, idealerna dö med sin tid och att man ej kan återwända till det gamla. ${ }^{\text {II }}$ (I89I Svenska litteratursällskapets möte)

The atmosphere is new, and so is the outlook. Reality, truthfulness to nature, is the new countersign and the poet is requested to reproduce this reality instantaneously. Naturalism and impressionism have made their way to us and conquered poetry. [...] When judging the new movement one will have to remember that, although the ideas may be eternal, the ideals will disappear with their epoch and that no return to the old is possible.

On the same occasion, Svenska Litteratursällskapet awarded its literary prize to K.A. Tavaststjerna as a worthy representative of the new trends in literature. It is worth noticing that there is nothing in Estlander's speech that suggests an opposition between naturalism and impressionism. In his view, the two movements rather seem to coexist peacefully, the latter an outgrowth of the former, sharing the same interest for what is described as

Io The art and literary historian Carl Gustaf Estlander (I834-I9Io), founder and editor-in-chief of Finsk tidskrift, was also one of the supporters of the project to erect a new building to host the Finnish National Gallery, Ateneum, that had opened in I863. The new building, designed by architect C.T. Höijer, opened up its doors to the public in I887. As chairman of Antellska delegationen I894-I905, a foundation devoted to acquiring art for the new museum, Estlander was well aware of the state of contemporary art.

II The following year, I892, at the annual meeting of Finska Konstföreningen (The Finnish Society of Art), Estlander pondered upon the rapid succession of artistic trends that he had foreseen in the above-mentioned quotation and came to the conclusion that the dominating trend «heter idag impressionism [...] - den heter imorgon symbolism» (qtd. in Ringbom I998: 2I6; «is called impressionism today [...] - tomorrow it will be called symbolism»). 
an accurate and instantaneous reproduction of reality ${ }^{12}$.

It is perhaps not surprising that the Swedish press of Finland should offer few and vague contributions to a debate that elsewhere had proved vital, especially through the polemics involving Erik Skram and Herman Bang on the pages of Tilskueren in I89o. With the exception of Geijerstam, who, in his reviews published in Finland, had made an attempt to clarify the relation between literary impressionism and the visual arts, and sought to describe the technique of two Swedish writers (Nordensvan and Strindberg) that he considered true impressionists, these latter contributors deal with (I) the need in Finland to imitate the 'impressionist' break with tradition, said to be present on the Swedish literary scene, and (2) the tendency of impressionism alongside naturalism to offer a more 'truthful' reproduction of reality. If it is correct to assume that the writers' attempt to adopt impressionism into literature as a potent modern force must have been shaped, to a certain extent, by their knowledge of the pictorial experience, we must bear in mind that in Finland, during the I880s, there was a less robust awareness of impressionism than in the other Scandinavian countries ${ }^{13}$. Although the first to mention the impressionists by name in the Nordic press was a Finnish art student, Bernt Lindholm ${ }^{\mathrm{I}}$, very few of the Finnish painters who came into contact with the new movement in Paris in the I870s and I880s put the impressionist theories into practice ${ }^{15}$. The reception of French impressionism seems to have been unenthusiastic, slow, and prevalently negative all through the years leading up to the first Finnish exhibition of French impressionists and neo-impressionists in I90I. The show, hosted at the Ateneum, presented works by Monet, Pissarro, Renoir, and Sisley. Bonsdorff comments that although many of the works exhibited were up to twenty years old, they were still perceived as a foreign novelty by the Finnish spectators, and the show was far from a success (Bonsdorff 2002: 269) much in the same way as Ateneum's I904 exhibition of French and Belgian art, which included, among others, Monet, Degas, Renoir, and Signac.

This second exhibition, however, encountered the favourable response of the art critic J.J. Tikkanen and brought the review Euterpe to publish three

I2 The same way of uniting realism, naturalism, and impressionism into a singular trend with the common aim of an accurate imitation of nature, had been exposed by Ferdinand Brunetière in an article that had appeared in a Swedish translation (Brunetière I88I).

I3 On impressionism and Finland see Reitala I967, Hintze I942-44, as well as Bonsdorff 2002 .

I4 In a letter to Helsingfors Dagblad, I8 February I870 (Lindholm I870), Lindholm describes the birth of a new artistic movement waiving the literary elements of painterly subjects in favour of the study of the juxtaposition of colours and the influence of atmospheric effects (air, light) on colours. Lindholm mentions Manet, Pissarro, and the Dutch painter Jonkind as the founders of the new current.

I5 Bonsdorff (2002: 263) mentions Albert Edelfelt, Axel Gallén, Eero Järnefelt, Torsten Wasastjerna, and Victor Westerholm as the only Finnish painters that could allow themselves to adopt impressionist techniques without losing their appeal on the art buyers in Finland. 
essays on the history and theory of impressionism written by the French critic Léon Deshairs ${ }^{16}$. Impressionism's long and winding road toward winning the Finnish art public's appreciation may have retarded the acceptance of the trend as a positive and evolutionary impulse in literature, and probably influenced the reception of literary impressionism mainly in negative terms. Furthermore, the newly awoken interest was soon broken by the general enthusiasm for national romanticism.

Thus, literary criticism that resorts to the definition in the Finnish press from the mid-eighties to the first decade of the twentieth century most often used impressionism as stigma. What is described as the impressionistic method is a technique judged too hasty, too superficial, and a much too nervous approach to writing to appeal especially to literary critics of an earlier generation, used to more traditional narrative techniques and to themes of national interest. Let us now take a look at some significant examples of impressionism as stigma, and see what authors were banished on the grounds of being 'impressionist' writers.

\subsection{IMPRESSIONISM AS STIGMA}

In Nya Pressen, 23 October I887, Arvid af Schultén reviewed Strindberg's drama Fadren (The Father) and had the following to say about the dramatist's depiction of reality:

Strindberg, som ibland roar sig med att uppträda som den mest själfsvåldiga impressionist, ofta nog lägger sina tillfälliga stämningar in i den omgifvande värkligheten, som han sedan målar med anspråk på att återge den, sådan den är. (Schultén I887)

Strindberg, who at times enjoys himself by behaving as an impressionist taking the greatest liberties, often applies his own temporary moods to the surrounding reality, which he subsequently proceeds to depict with the pretence of reproducing it exactly the way it is.

Strindberg is thus 'guilty' of distorting the principles of impressionist perception almost to the point of becoming an expressionist who transmits his own moods to the milieu before reproducing it. Schultén speaks of «Strindbergs alt [sic] skarpare framträdande subjektivitet» («Strindberg's ever more apparent subjectivity»): substituting naturalistic objectivity with the personal impression was, as we have seen, present in the 'bohemian' understanding of impressionism as modern subjective writing.

I6 See Tikkanen I904a, I904b; Deshairs 1904a, I904b, I904c. 
In Hufvudstadsbladet, I4 December I895, the signature 'Ar.' labels Jonatan Reuter's collection of short stories Lovart och lä: bilder och stämningar (Windward and Sheltered: Images and Moods) «en impressionistisk produktion» ('Ar' I895; «an impressionist production»). In this case the adjective 'impressionist' stands for a superficial subject choice and a much too hasty and sketchy manner of «throwing down on paper» the author's own «impressions», but still recalls the impressionist artists' desire to deliver images of modern life with all its rapid movements and fleeting moments in a manner that did imply a fast execution. This idea had been expressed by Baudelaire in Le Peintre de la vie moderne (1863; The Painter of Modern Life): «il y a dans la vie triviale, dans la métamorphose journalière des choses extérieures, un mouvement rapide qui commande à l'artiste une égale vélocité d'exécution» («there is in everyday life, in the daily metamorphosis of externalities, a rapid movement that requires of the artist an equal velocity of execution»). The need to suit the word to the action is in this case however not captured by the literary critic, who is unable to judge the method as anything but shallow and careless.

There are several other examples that illustrate the general feeling that impressionism was a style of exaggeration and neglect. Gustaf Cygnaeus, writer and editor of Åbo Tidning, wrote on I6 June I9oo (under the signature of 'G.C.') of the Dutch writer Louis Couperus's novel Under vänskapens ok (Footsteps of Fate, original title, Noodlot) that it was a work which wished to stay clear of «impressionismens öfverdrifter» («the exaggerations of impressionism»). A few months earlier, on 24 February I900, Hufvudstadsbladet had reviewed Brausewetter's work Finska författarsilhouetter (Silhouettes of Finnish Authors) and reported that the author had found Mikael Lybeck an «impressionist» and therefore «unsatisfying» as a writer. On 3 February I9OI, the same paper made a mention of Oscar Levertin's review (published in the Swedish paper Dagens Nyheter) of Lybeck's novel Den starkare (The Stronger) and quoted the following words written by the renowned Swedish critic: «den som läst hans med en orolig och obehärskad impressionism berättade noveller, väntade knappast af hans hand ett värk [...] som denna [...] roman» (I9OI Literatur, konst; «the one who has read his short stories, told with a nervous and uncontrolled impressionism, would hardly have expected [...] a work like this novel to be written by him»). Fritt Folk, I2 January I907, finally comments on Adolf Paul's drama Djävulskyrkan (The Devil's Church) and goes back to the idea of impressionism as a rapid and rough subjectivism:

Som författare är och förblir han impressionist, skriver ned sina infall i rasande fart, utan vidare kritiskt betänkande. På ingivelsen tror han vida mer än på självkritiken, som kanhända ofta vil blanda sig i saken, och allra minst bryr han sig om att ställa 
sig utom verket för att försöka se på det med den utomståendes ögon. Därför blottställer han sig mer än de flesta. ('Se' 1907)

As a writer he is and remains an impressionist, annotating his whims in a fury without further critical consideration. He believes more in instinct than in self-criticism, which often, perhaps, might want to interfere, and he does not even bother to step outside his own creation in an attempt to observe it with the eyes of an outsider. This is why he lays himself bare more than most.

Superficiality, absurdity, and insubstantiality were qualities with which Louis Leroy had deliberately charged the term impressionnisme when he coined the word in I874 after having seen Monet's I872 painting Impression, soleil levant (Impression, Rising Sun). These few examples from the Finnish press are significant and, I think, sufficient to illustrate how the label of 'literary impressionism' continued to be used to convey stigma long after its painterly counterpart had lost the association with the notion of absurdity. The words with which Adolf Paul, as late as 1907, is 'disdained' as an impressionist are highly reminiscent of the comments that the Swedish art critics reserved for the much too radical French impressionists in the I870 (see Hedström 2002: 50-5I). But then again, as we have seen, it was not until the Helsinki exhibition in I904 that the impressionists were received somewhat positively in Finland.

\subsection{MIKAEL LYBECK, K.A. TAVASTSTJERNA}

Even though these commentaries for the most part feel as 'impressionistic' (in the sense of 'elusive' and 'superficial') as the impressionism that they are trying to elucidate, there were a few exceptions (mainly quotations from Swedish papers) that went as far as attempting a description of the technique involved in the impressionist rendering of reality. Nya Pressen, I8 March I894, under the headline 'Literatur o konst': Svenskt omdöme om finska författares böcker ('Literature and Art': Swedish Opinions on Books by Finnish Authors) cites a review dedicated to the above-mentioned Mikael Lybeck that had appeared in the Swedish newspaper Svenska Dagbladet the same month, signed '-pt-'. The journalist reports that Lybeck's novel Allas vår Margit (Our Dear Margit) is seen as a work stylistically close to Herman Bang's Tine (I889), and quotes from the Swedish article:

Dentillhördenimpressionistiskariktningen, skildrarväsentligen blott hvad man ser och hör, utan att närmare redogöra för de uppträdande personligheternas förhållanden, motiv eller ka- 
raktärer eller lägga dessa fram i och genom handlingarne. [...] Ett dylikt stilla småstadslif, som här förekommer, egnar sig mindre än något annat för impressionistisk skildring. Det skall vara mera händelserika, rörliga och lifliga förhållanden, som skola kunna uppehålla en skildring af detta slag. Det enda vi förut ega i den nordiska literaturen, som ej är misslyckad, ehuru äfven den kan gifva anledning till olika omdömen är Herman Bangs Trine [sic], men denna har också just till hufvudmotiv de upprörda dagarna vid Dybböls fall och Als' eröfring. (I894 'Literatur o konst')

It belongs to the impressionistic movement and reproduces primarily only what one sees and hears, without accounting in detail for the relationships among the characters involved, their motives or personalities, which are instead exposed in and through their actions. [...] The quiet small-town life that we are presented with is much less suitable for an impressionist rendering than anything else. What we need to sustain this kind of story-telling are dynamic, animated and lively conditions. The only successful example in Nordic literature of such a description is Herman Bang's Tine on which there are many opinions; this novel, however, still has as its main motif the savage days before the fall of Dybbøl and the conquest of Als.

Lybeck's impressionist technique is only partly accomplished according to the reviewer. In depicting the protagonist Margit, Lybeck renounces his objective stance and gives the reader access to her interiority. This exception to the rule is, however, not the true reason for the critic's dismissal of the novel, which instead is due to what is felt as Lybeck's incapacity to match technique with subject matter and to a certain fleeting sketchiness in the execution that encumbers the writer's talent ${ }^{17}$.

Herman Bang, sometimes regarded as the 'only' Scandinavian impressionist, appears a few years later side by side with Mikael Lybeck as Hufvudstadsbladet, 8 December I900, refers the Swedish newspaper Dagens $N$ Yheter's opinion of Lybeck's novel Den starkare. The Swedish reviewer had been astonished to find that the somewhat obsolete impressionism was still producing works of literature, though he finds Lybeck's impressionism «less tiring» than the one of his master, Bang:

I7 Cf., «Den konstnärliga metodens olämplighet för ämnet och det ofta ytterst flyktiga skisserandet i teckningen hindrar den [Lybecks talang som författare] att komma till sin rätt» (I894 'Literatur o konst'; «The impropriety of the artistic method when applied to this subject matter and the often extremely fleeting sketchiness of the portrayal prevents [Lybeck's talent as a writer] from shining through»). 
Det på en gång lugnt och nervöst impressionistiska framställningssättet [...] värkar som en hälsning från tio år tillbaka, ett dylikt skrifsätt är ej modernt nu i dag, men det hindrar inte att det visar sig vara lifligt målande, och det blir här ej tröttande, som det onekligen varit hos en och annan af denna stils typiska företrädare, Herman Bang till exempel. (I900 Om Mikael Lybecks)

The calm and at the same time nervous impressionist rendering [...] comes across as a souvenir from ten years ago; this way of writing is no longer modern today, but that does not stop it from being lively and evocative, and in this case it does not become tiring, which undeniably has been the case in some of the typical representatives of the style, as for example Herman Bang.

This reference to Herman Bang adds yet another ingredient to the soup of conceptual uncertainty which had been boiling since the I88os when the Scandinavian critics first tried to trace the essence of literary impressionism. As we have seen, Herman Bang's approach to the subject of impressionism had initiated a discussion that was pushing the interpretation of literary impressionism closer to the theatre stage. Bang himself (I908: 678), would go as far as to suggest that the definition 'the impressionist novel' be replaced by the Danish expression den fremstillede Roman («the scenic novel») which, according to him, had the advantage of being less hazy and, alas, 'impressionistic'. This new expression, which Bang considered of immediate comprehension, communicated a technique that involved presenting characters, actions, and environments dramatically. What is known about the universe of the novel would emerge primarily from how it appeared to the eye and from the way characters acted and spoke. However, this idea of denying the reader access to the minds of the characters and limiting description to the observable, are elements of the impressionist mode that have given critics yet another reason to speak of impressionism in terms of a stigma. The American scholar James Nagel observes that it is precisely these limitations that have made impressionist fiction seem shallow and superficial (I980: 27). But Nagel also makes it clear that adopting and respecting a literary method should not in itself be mistaken for a flaw in the art of telling a story:

In short, to present characters without prior knowledge, and on the basis of dramatic revelation, is to sharply limit the depth of all but the major figures. This practice, however, does not represent a conceptual weakness so much as an adherence to restricted narrative modes. (Nagel ig80: II6) 
In my survey of the literary criticism in the newspaper press, K.A. Tavaststjerna is the last example of an author whose work is referred to as impressionist. Furthermore, Tavaststjerna is also a writer with an interest in art. In a letter from Paris (Bref från Paris) published under the pseudonym 'stst' in Nya Pressen, I9 February I884 (Tavaststjerna I884) a year after the death of Manet (an event that led to the dispersal of the group of impressionist painters), Tavaststjerna reviews the retrospective at L'École des Beaux Arts dedicated to this painter. Here, Tavaststjerna demonstrates his awareness of the contemporary painters' intense use of the blue shadow, a detail that was central to the impressionist perception of colours. The portrayal of the art critics' alarm is almost caricatural, as Tavaststjerna mentions how those «blå dagrar få kritikerna att visa sina maskätna hörntänder och publiken ropar 'mera natur, mera natur!» (Tavaststjerna I884: «blue shadows make the critics show their worm-eaten canines and the public shout 'more nature, more nature!'»). Although he does not mention impressionism, the writer sees Paris as the meeting point for modern realism and idealism.

Hans Lund (I993: 58) claims that Tavaststjerna found the literary equivalent to pictorial impressionism in the new idealism of the I89os, an opinion he shared with the Norwegian Arne Garborg and one that comes forth in Tavaststjerna's short story Impressionisten (Tavaststjerna I892; The Impressionist), published in the collection of short stories entitled Unga år (Youth). Many reviewers, among them Ellen Key (Key I898) and Gustaf af Geijerstam, came to consider Unga år as his best work. In April I894, Geijerstam travelled to Helsinki and St. Petersburg, presenting a series of lectures on literature to the Finnish audience. When he spoke on Tavaststjerna on 6 April I894 in Helsinki and I7 April I894 in St. Petersburg (I894 'Literatur o konst'; I894 Åbo Tidning I4 February) he attempted to demonstrate how Tavaststjerna's short stories were aesthetically opposed to the triteness and triviality that had dominated the literature of the I88os. According to the journalist who reviewed his speech in Helsinki, Geijerstam quoted heavily from the short story entitled Impressionisten.

The thematic centre of Impressionisten lies in the subjective ability to see. It recounts the story of a man whose capacity for reading the surface is extremely well developed. The protagonist has a mature sensibility for judgments based on impressions, which is almost supernatural. The short story caused several critics, such as Werner Söderhjelm and Gustaf Chygnaeus, to speak of a modern mysticism that recalled Ola Hansson ${ }^{\text {I8 }}$. If the title implies that this extreme confidence in subjective perception stems from the impressionist experience, there are, on the other hand, other voices that focus on aspects of Tavaststjerna's writing that seem to emanate not

I8 'W.S.' (I892) compares Tavaststjerna's character who possesses «en känslighet, så sjukligt öfverretad» («a sensibility, so sickly overstimulated») to Ola Hansson's Sensitiva Amorosa. 'G.C.' (I892) talks of the impressionist protagonist as a «fysionomist» and in general of Tavaststjerna’s modern mysticism «à la Ola Hansson». 
so much from the perceptional and phenomenological problems central to the impressionists' exploration, as from its attention to light and colour and attempts to capture a moment of a shifting reality. In the Kotka notis- och annonsblad, 29 September I892, 'W-t' thus mentions the «flyktiga, veka stämningar» («fleeting, vague moods») that dominate Unga år, and describes the short story Vinden vaknar (The Wind Rises) as «en situationsbild, en ögonblicksfotografi af ett sommarlandskap med solljus, barrdoft och tvänne unga mänskobarn [...]. Man tycker sig se solljuset, insupa doften från barr och linnen och känna med de unga» («an instant picture, a snapshot of a summer landscape with sunlight, the perfume of pine trees and two youngsters [...]. One has the feeling of seeing the sunshine, breathing the perfume of pine trees and linen and sharing the feelings of the young»).

After Tavaststjerna's death in I898, 'Hj. Ö' reviewed the posthumous collection of short stories Efter kvällsbrisen (After the Evening Breeze) in Hufvudstadsbladet, I7 May I899, and spoke of a man who became a poet in the years when «realism and impressionism dominated the arts and taught us to love the sparkling richness of colours that surround us». «Det finnes mycket af målaren-impressionisten hos Tavaststjerna» ('Hj. Ö’ I899; «There is a lot of the painter-impressionist in Tavaststjerna»), the reviewer writes, likening Tavaststjerna's stories set in Italy to «akvareller af impressionismens yttersta mästare» («watercolours of the greatest impressionist masters»).

\subsection{FINSK TIDSKRIFT}

I would like to conclude this survey of criticism with a brief examination on the use of the term in the journal Finsk tidskrift during the same period. This examination will add yet another two names to the list of Swedish-speaking writers in Finland concerned with literary impressionism: Helena Westermarck (1857-1938) and Gerda von Mickwitz (1862-I948). Furthermore, the name of painter and writer Westermarck elicits yet another way of looking at impressionism in literature, namely as a prose that shares the impressionist painters' interest in modern, urban, subjects such as the Parisian street view seen from above (as in Geijerstam's previously mentioned example) as well as some of the principles of representation involved in the rendering of these subjects, such as framing and point of view.

Finsk tidskrift, founded in 1875 , is the earliest example of a review dealing with cultural issues that is still being published in Scandinavia. Erik Ekelund deems its role as a transmitter of literary impulses important, but also states that its general attitude in cultural matters was rather conservative (1969: 380). However, this conservative trait is not evident in the art criticism that turned the readers' attention to impressionism. Apart 
from Albert Edelfelt's reportage from Paris in 1877, in which the Finnish painter condemns the impressionist exhibition of the year as «an artistic madhouse» (Edelfelt I877: 343), Finsk tidskrift primarily relied on the expertise that the art critic Georg Nordensvan dispensed in his letters from Sweden up until I896. Although Nordensvan in I883 felt the need to distinguish the radical impressionists as noxious novelty-makers with «vämjeligt råa framställningssätt» (Nordensvan I883b: 4I9, I883c: I8; «horribly crude rendering») from the moderate representatives of the school, such as the Norwegian Werenskiold and the Italian De Nittis, in I885, on the other hand, he wrote a straightforward defence of «pariserskolan». These Swedish painters, based in Paris and strongly influenced by impressionism (among others Krouthén, Kindborg, Liljefors, and Kreuger) are presented as a young force capable of bringing sanity and healthy ideas into contemporary art (Nordensvan I885: 75, 78). In his appraisal of Konstnärsförbundet's I89o exhibition in Stockholm, where the most recent efforts of the Swedish plein air and impressionist painters were on show, Nordensvan concludes that «individualism» would be a more appropriate definition than «impressionism» (I890: 48I).

In the following issue of the Finsk tidskrift, the editor of the journal, C.G. Estlander, expressed an opinion which is both in favour of the impressionist experiment and a confirmation of the late acceptance of impressionism in Scandinavia. In a review of Gustaf af Geijerstam's collection of short stories entitled Fattigt folk (Poor People II) from I889, he points out the story Utan pängar (Moneyless), that sees its painter-protagonist living from hand to mouth until he finally manages to sell a painting. Estlander comments: «troligen går det honom sedan mycket bra, impressionist som han är» (I890: 62; «being an impressionist, he will likely become quite successful later on»).

C.G. Estlander also helped introduce the Finnish artist Helena Westermarck, his friend and collaborator, as an interesting case of a Doppeltbegabung on the pages of Finsk tidskrift. As a painter Westermarck was trained in Helsinki and Paris, and the Parisian art and literary scene serves as the backdrop for the articles she wrote for Finsk tidskrift in the I880 ${ }^{19}$. Ur studieboken, berättelser och utkast (From the Sketchbook, Stories and Drafts) was her literary debut in I890. It may be assumed that the choice of title, which includes the word utkast «sketch, draft» reveals a writer both affected by the dialectics of word and image as well as her wish to adhere to one of the literary modes of the day, i.e., the unfinished fragment. However, it is clear that Westermarck draws on her personal experience of visual rendering when elaborating some of the short stories that make up the collection. Estlander reviewed positively both the first and the second volume of Westermarck's literary sketches by stressing the way her very modern technique and capacity for observation depended upon her painter's eye (Estlander ı891: 57, 59). Estlander does not explicitly

I9 See Westermarck I884a, I884b, I884c, I892, I893. 
refer to the impressionist experience, but when mentioning the short stories Aftonstämning (Evening Mood) and I marginalen af en museikatalog (In the Margin of a Museum Catalogue) he comments on the former as an account of «vårluften och lifvet på den trånga gatan i Paris, sådan man ser den från femte våningens vindskupa» (I891: 58; «the spring air and life in a narrow Parisian street, as seen from the small attic window on the fifth floor») and on the latter as an example illustrating his opinion that the art of any age has its excellence and its appropriateness as long as it interprets the spirit of its own age (I891: 57-60) ${ }^{20}$.

It must be added that the true subject of Westermarck's I marginalen af en museikatalog (Westermarck I89ob), set in the Uffizi museum in Florence, is the defence of the Danish impressionist and plein air painter Peder Severin Krøyer (I85I-I909). With reference to Aftonstämning (Westermarck I89oa), I will argue in section II of the present work that this short story should be considered as an example of the way in which literary impressionism can be explained as directly influenced by painting. Here, Westermarck puts a painterly theme which had become a leitmotif in impressionist art by the time Westermarck took up her art studies in Paris, i.e., the street scene from a bird's-eye view, into words, and ponders upon air, atmosphere, and light, though especially on the effects of light on objects more than on the light itself ${ }^{21}$. The idea of choosing a subject from 'impressionist Paris' can also be seen as a case of translating painterly motifs into literature that somehow reverses the efforts of the impressionists to turn modern painting away from literature and storytelling, which was partly the reason for its distinction from academic painting with its stress on the anecdote and on historical subjects.

Closely linked to this way of translating painting into literature is the Danish critic Richard Kaufman's report from the French literary scene, in which he records the writers' manner of adopting landscape description in a way reminiscent of the paysagistes. Through the choice of their subjects, Kaufman (1886: I60) defines Pierre Loti's Pêcheur d'Islande (An Iceland Fisherman) and Ferdinand Fabre's Monsieur Jean as «romans de plein air»

20 The concept of art and literature as image and expression of the times brings us back to Christian Krohg's slogan, deriving from his need to find expression for an acute feeling of living in a new, frantically modern, era. In his writings, as we have seen, Krohg was very much concerned with the need for transmitting «tidens billede», an image of the contemporary age and its people.

2I The signature 'Scylla och Charybdis' also commented on Westermarck's acquaintance with impressionism in a review of her work for Finsk tidskrift in I883: «Frk. W. har tidigare studerat i Paris och der blifvit bekant med den modernaste af alla franska skolor, den som proklamerar att allt är skönt som är naturligt och hvilken vill göra konsten till ett slags färglagd ögonblicksfotografi» (I883: 476; «Miss W. has previously studied in Paris, where she has grown familiar with the most modern of all the French schools, the one that proclaims that anything natural is beautiful and wishes to make of art some kind of coloured snapshot photograph»). 
(«plein air novels») $)^{22}$. It can also be added that the epithet of «Friluftsstämningsförfattare», indicating the writer's capacity to render plein air atmospheres, recurs in the Finsk tidskrift ('H.R.' I9OI) with reference to Jonatan Reuter, one of the writers identified with the impressionist mode by the literary criticism in the previously examined press reviews ${ }^{23}$.

A final attempt by the critics to pin down literary impressionism was evoked by Gerda von Mickwitz's debut Solglöd och andra skizzer (Mickwitz I885; Sunglow and Other Sketches). Mickwitz's collection of short stories was received by the critics as stylistically and thematically heavily dependent upon the modes of J.P. Jacobsen and Herman Bang (cf., 'B.E.' I886). This reference to the Danish impressionists is confirmed by Arne Toftegaard Pedersen's distinction of three subgenres within the short story writing in the Finnish I880s, according to which the scholar identifies the representatives of «den impressionistiske, dekadente novelle» (2002: 60; «the impressionist, decadent short story») precisely with von Mickwitz's debut, as well as with two of the writers previously connected with the impressionist mode, namely K.A. Tavaststjerna (early works) and Mikael Lybeck (the two short stories Kväfd [Suffocated, I884] and Fragment [I885]). It is worth noticing that the signature '-r' comments on «den impressionistiska stämningskärleken» (I886: 60; «the impressionist love for moods») that seems to permeate this latter story.

The critical category of literary impressionism suggested and hinted at in various ways in the Finnish press from the early I880s onwards was straightforwardly adopted as a term in I907, when Irene Leopold discussed Herman Bang's novel De uden Fodreland (The Ones without Home Country) in Finsk tidskrift. Leopold charges the expression with the meaning that was specific to Bang himself, who spoke of the impressionist novel as a piece of work that drew close to drama and that suppressed, as far as possibile, the presence of the narrator in favour of the interplay between characters and reader. The essence of literary impressionism is, according to Leopold, the act of perceiving impressions, not only visual but also acoustic. When Bang, in his novels, registers conversations at a dinner table paying attention to all the possible interferences that are likely to occur in any authentic dialogue he thus achieves the effect of turning impressionism into a realism as close to reality as it can get:

Något mera talangfullt och för manéret typiskt än denna brokigt gnistrande dinerkonversation har den litterära impressionismen ej att uppvisa, åtminstone ej i dessa dimensioner, där ett tjog in-

22 Loti's novel is the main point of interest in Richard M. Berrong's book discussing how Monet's impressionism was transposed into words, cf., Berrong 2013.

23 In his Pariser-krönika (1890; Parisian Chronicle), Kaufman recognized the impressionists as one of the modern literary schools in France alongside decadents, symbolists, and «terrorists à la Maeterlinck». 
divider karakteriseras af de korta replikerna under sekundernas flygande prestissimo. (Leopold I907: 4I2)

Something more talented and so typical of the mode as this colourfully sparkling dinner conversation has never been portrayed by literary impressionism, at least not in these dimensions, where some twenty individuals are characterized by the brief lines in the flying prestissimo of seconds.

\subsection{CONCLUDING REMARKS}

Whether the Finland-Swedish writers labelled impressionists agreed with the views and opinions of the critics on their work remains to be discovered. The Scandinavian writers connected with the movement, first and foremost Herman Bang (who rarely used the term and ultimately came to consider it an incomprehensible foreign idiom) did not invent the definition to characterize their own works. If literary impressionism more than anything seems to be «une affaire de critiques» (Pouzet-Duzer 2008: I24; «purely a matter for critics»), it is interesting to note that this category, created by Brunetière and his fellow critics in the late nineteenth century, was often looked upon as suspicious - often by the very same critics that made use of the term, and most certainly by their twentieth-century followers. This survey has tried to offer insights into the different literary expressions commonly collected under the rubric 'impressionism' and highlight the diverse talents in Swedish literature critically identified as the major representatives of impressionist prose. As to the former aim, the examples cited here clearly demonstrate how the term was used with various nuances by literary critics within a period of approximately thirty years. A variety of concerns, styles, and techniques gather under the heading of literary impressionism, some of which, but not all, were shaped by the pictorial experience that was slow to win acceptance in Finland, a fact that certainly helps to explain the hostility the term encountered. Thanks to the mediation of Geijerstam, who introduced it into the critical discourse in $\mathrm{I} 884$, however, the Finnish readers were acquainted rather early, at least from a Scandinavian point of view, with the idea of impressionism in literature.

One sometimes encounters the opinion that the term 'literary impressionism' should be dropped from the critical vocabulary since no single interpretative formula of a concept hosting such a wide range of experiments can be considered valid. Still, although the idea of literary impressionism encompasses, as we have seen, a great critical range, the materials taken into account for this section present a number of features common to most international dicussions of this phenomenon. In short, the keys to 
understanding impressionism in literature offered by the literary criticism in Finland, within what can reasonably be considered the historical period of impressionism, are: (I) metonymic descriptions that avoid cataloguing to concentrate, instead, on a set of representative details; (2) a prose that keeps to the sketch and the fragment to the point of abandoning the plot, while favouring the passing mood over any permanent condition; (3) a subjective naturalism, stemming from the idea that the subjective impressions are the only reliable data; (4) a writing bearing resemblance to the themes, the framing, and oblique angle of vision in impressionist painting, as in the works of writers most likely acquainted with the major works of the impressionists (plein air prose, scenes from 'impressionist Paris', descriptions of shifting light, and the play of reflections that suggest a mood or an atmosphere); (5) texts that draw on Bang's unique impressionism that demanded its own terminology and implied, among other things, the use of an impassive narrator that did not intrude into the impressions of the characters and of certain stylistic devices and relied on the senses as the only source of information; and finally, (6) the compositional horror that derives from a rapid and rough sketching and a seemingly careless perception of reality. Wylie Sypher's considerations on the impressionist experiment in art and literature eloquently sum up my sensation that there is not so much a need for a redefinition of the term 'literary impressionism' as for an acceptance of the various ways in which the concept can be interpreted:

It is true that many of the so-called impressionist painters often used the same brushwork and color and subjects; yet they differed from each other in almost every other way. If Manet is an impressionist, what are we to call Renoir? If Renoir is an impressionist, where shall we place Degas? What are we to think of Cézanne, who is - and is not - to be identified with the group? Does Bazille really belong? [...] These interactions must shake our confidence in any single definition of impressionism, which is rightly called multiple. No matter what one says of the impressionists, it is never entirely trustworthy. They have no method - only methods. (Sypher I960: I70) 



\section{6.}

\section{SUMMARY}

The argument here has been the recent revival of critical interest in the impact of impressionism on literature, as well as the variety of literary impressionisms that one encounters historically, both on the international scene and in specific Nordic contexts. Although the French impressionist painters are still, as they were in earlier studies, «a fairly solid core of reference» (Muller 1938: 356) for scholars working on this subject today, interart comparisons have by no means been the only way of coming to terms with the notion of literary impressionism - not even in the age of impressionism, and especially not in the Nordic countries, as I have tried to demonstrate. While the critical survey at the end of this section has shown that, just like in Britain and France, also within the Swedish context «the term was [...] extended to ways of writing which were thought to possess the qualities popularly attributed to the painters [...] works that were spontaneous and rapidly executed, that were vivid sketches rather than detailed, finished, and premeditated compositions» (Watt I980: I72), turning the spotlight on three landmark interpretations of literary impressionism in Scandinavia has proved that there also existed other, quite different concerns in the applicaton of the term. An author such as Herman Bang, on whose status as the foremost Scandinavian prose impressionist there is a general consensus, cultivated an understanding of literary impressionism that drew close to the theatre stage, while a grouping such as the Norwegian Bohème of the I88os adapted an interpretation of impressionism as «a licence to write subjectively» (Bender 1976: 50) in the heydays of objective naturalism. Strindberg's engagement with impressionism, both pictorial and writerly, shows that the author's interest in the impressionist school was mainly due to its association with modernity, lunacy, and rebellion.

The examination of the use of the notion in the Finland-Swedish press has shown that what reviewers and critics included in the idea of literary 
impressionism was a combination of the aforementioned aspects; i.e., not only a way of coming to terms with the writers' various ways of adapting the technique of the impressionist painters to fiction, but also texts inspired by Bang's impressionism, as well as works animated by a subjective naturalism. As we have seen, literary impressionism also provided these journalists with an apt definition for writings connotated by fragmentary compositions and a careless perception of reality, as in the popular and unfavourable understanding of painterly impressionism. Lastly, this section of the present work has also supplied a few names of authors writing in Swedish that will concern the following part of the study. 
PART II

MODES OF LITERARY IMPRESSIONISM. TEXTUAL ANALYSES 



\section{I.}

\section{TRAJECTORIES INTO THE HEART OF THE MATTER}

The following pages are concerned with forms of literary impressionism present in late nineteenth-century Swedish prose fiction and, specifically, with the narrative techniques employed in the texts that are up for scrutiny. Impressionist techniques in writing is an argument that undoubtedly calls attention to the question of the relationship between literature and the visual arts: are these writerly techniques no more and no less than ut pictura poesis? Are there ways of transferring the means and the methods of painting to verbal art? Is it rather the act of perception characteristic of impressionist writing that should be likened to that of the impressionist painter? Or does verbal impressionism follow a completely different set of rules? While Ford Madox Ford, in I9I4, sustained the modernity of those writers who attempted to transfer impressionist painterly techniques into their own medium, words, many recent scholars with an interest for literary impressionism have produced studies stressing the distance between impressionist writing and impressionist painting, rather tracing literary impressionism back to the philosophical thinking of Hume, Locke, or Merleau-Ponty ${ }^{\mathrm{I}}$. To Ford Madox Ford's strident appeal in the essay On Impressionism (Hueffer I9I4a and I9I4b), which goes:

Do not, I beg you, be led away by the [...] cant phrase [...] that the Futurists are trying to be literary and the plastic arts can never be literary. Les Jeunes of to-day are trying all sorts of experiments, in all sorts of media. And they are perfectly right to be trying them. (Hueffer I9I4a: I74)

a contemporary scholar such as John Peters (2001: 15) replies, it would seem, dishearteningly: «although impressionist art and literature share similar

I See e.g., Peters 200I, Matz 200I. By contrast, Richard Berrong goes back to interart comparison in his recent readings of Pierre Loti's Pêcheur d'Islande, cf., Berrong 2006 and 2013. 
philosophical concerns, their techniques for representing those concerns usually differ considerably because of the differing media they employ».

Within the Scandinavian context, the first broad study dedicated to literary impressionism, Sven Møller Kristensen's Impressionismen i dansk pro$s a$, begins on the track marked out in Ford's essay. Møller Kristensen thus considers the phenomenon as one taking more than nominal inspiration from the impressionist school of painting, primarily by sharing the painters' passive attitude towards their subject, an aspect which, according to this scholar, is made visible in the style of impressionist prose:

I litteraturen medfører impressionismen en omdannelse af stilen, der er parallel med revolutionen af den maleriske teknik. Den psykologiske baggrund er den samme: der foregår en forandring i kunstnerens indstilling til virkeligheden, fra en forarbejdende til en blot modtagende. (I955: 22)

In literature impressionism brings about a change in style, which is parallel to the revolution that occurred in painterly technique. The psychological background is the same: there is a change in the artist's attitude towards reality, from a preparatory [stance] to plain reception.

On the subject of syntactical logic, which Møller Kristensen declares as good as non-existent in impressionist writing, the scholar grows bolder in his search for interart analogies, so much so as to set up an equivalence between the absence of preparatory sketching in the visual arts and the abandoning of grammatical correctness in the domain of writing: «den litterære impressionistiske teknik er her ganske parallel med den maleriske: malerne forkastede tegningen som grundlag for maleriet, forfatterne brød med den overlevende logiske syntax for at forøge sprogets maleriske kaft [sic]» (I955: 92; «the literary impressionist technique is in this case quite parallel to the painterly: the painters denied the use of drawing as the basis for painting, the writers broke with the surviving syntactical logic in order to boost the pictorial force of language»). In spite of these cursory equivalences to the visual arts, Møller Kristensen mainly concentrates on grammatical and syntactical questions and does not discuss literary impressionism as a writing focussing on motifs common to the painterly movement, nor does he delve deeper into the ways in which the painters' compositional techniques or representational methods might be transferred to literature. This is where we need to reassess his suggestions.

In an attempt to explore the craft of literary impressionists and clarify to what extent Møller Kristensen's equation between verbal art and visual art needs to be recalculated, the point of departure for the textual analyses that 
will be carried out in this section of the present work is to pursue the two principal trajectories outlined in the international literature on impressionism in prose. These two lines of interpretation have recently been summed up by Florence Dumora as follows:

L'emploi d'impressionniste' pour la littérature a deux origines possibles: l'une, médiate, suppose la transposition de la peinture à la littérature, l'autre, recentrée sur l'étymon, définit une littérature qui procède par impression, par opposition à celle qui analyse, juge ou construit. (Dumora 20I2: 30)

The definition of 'impressionist' as applied to literature has two possible origins: the first understands it indirectly as a transposition of painting into literature, the other, by going back to the philological meaning of the term, designs a writing that proceeds through impressions, as opposed to analysis, judgement, or construction ${ }^{2}$.

This choice, it must be admitted, leaves out the investigation of possible Swedish correspondences to the singular interpretation of impressionism as a subjective naturalism concentrating on the writer's autographical experience, which was central to the Norwegian, bohemian, understanding of the investigation issue, as we have seen. However, though mainly concerned with the textual rendering of visual perceptions, my use of the second interpretive category - generalized by Dumora as «a writing that proceeds through impressions» - does accommodate a side step from this second trajectory which remains faithful to the wide-ranging Scandinavian use of the concept of literary impressionism. Through a reflection on what place Herman Bang's scenic impressionism holds within a literary tendency shunning analysis and judgement, and counting, instead, on the reader's collaboration in the process of giving sense to the text, I intend to respect the extensive use of the term evident in its employment in the Scandinavian

2 As we have seen, Ferdinand Brunetière was the first to indicate the direction of the trajectory tracing literary impressionism back to the visual arts in his essay from $\mathrm{I} 879$. $\mathrm{H}$. Peter Stowell's works (I980 and I984) are instead symptomatic of the second, cf., Stowell (I984: 538): «the stylistic foundation of impressionism is the creation of linguistic and rhetorical effects that render sensory impressions on eyes, ears, and consciousness. Impressionist characters rarely think causally or conceptually. Instead, if they aren't directly involved in a sensory experience, their consciousnesses are sorting, resorting, and synthesizing perceptual fragments experienced over time, but reexperienced in each present moment. There is a dramatic and terribly important ontological shift from the verb "to be" to "seems", "appears", or "it was as if". These tropes underscore the tenuous nature of perceived reality, thrusting at the reader the textures of unknowable surfaces. The world of impressionism is the world of appearances $[\ldots]$ with the accelerating pace of sensory stimuli constantly assaulting the perceiving consciousness, it becomes possible to deal with the reality of surfaces only». 
tradition, which differs from the less encompassing significance it has taken on in an international context.

Through a close reading of a short story written by the Finland-Swedish painter and writer Helena Westermarck, I will enter the first trajectory: literary impressionism as a transposition of painting into literature. I will argue that Westermarck's short story Aftonstämning, published in I89o, is a useful and convincing example of how a writer, well-versed in painterly techniques and a connoisseur of French impressionism, transferred a subject familiar to impressionist painting - as well as the means and the methods of this school - to prose.

As regards the second interpretive course, impressionism as a writing building on the rendering of impressions, I have singled out Stella Kleve's authorship to lay bare an inspiring case of the adoption of some of the more substantial impressionist writerly techniques charted in the previous section of the present work. Moreover, next to Herman Bang, this author is also one of the few Scandinavian writers to have thought of herself as a literary impressionist, as we will see. Specifically, I will look at the ways in which Kleve's texts concur: (I) with the maxim of Herman Bang's impressionism, according to which literary impressionism is to be understood as «den iscenesatte fortælling» (Møller Kristensen I955: 34; «a staged narration»); (2) with two distinctive features of impressionist writing, firstly with what I have called 'the metonymic mode', following up on Møller Kristensen's discussion of the role of metonymy in Danish literary impressionism (Møller Kristensen I955: I23), and, secondly, with a technique variously known as 'delayed decoding' (Watt I972 and I980), the 'uncorrected chronicle' (Hueffer i9I4a: I73) or 'phenomenological apperception' (Møller Kristensen I955: II9-34). I will also reflect on the function of the punctuation peculiar to Kleve's prose; an aspect, which again resonates with Bang's distinctive stylistics.

Lastly, with the aim of testing the cogency of the hypothetic evaluations put forward by the contemporary critique, which, as I have demonstrated in the critical survey dedicated to the Finland-Swedish press, held Georg Nordensvan's and Mikael Lybeck's texts to be representative of literary impressionism, I will scrutinize aspects such as the metonymic mode, the unobtrusive narrator, and scenic impressionism in the prose of these two authors. 


\section{IMPRESSIONISM AS LITERARY PICTORIALISM: HELENA WESTERMARCK}

The attempt by writers to capture the motifs of the painters appears to be at the same time both the most evident and the less investigated mode of decoding the concept of literary impressionism at least in Scandinavia, where scholars mainly have dealt with the grammar, the rhetoric, and the stylistics of the phenomenon (Møller Kristensen 1955; Dahl I969; Lund I993; Nilsson I965; Rykkja I972). Still, the claim that literary impressionism occurs when a writer strives to reproduce the motifs and the technical methods of the impressionist painters in words, was, as we have seen, at the bottom of the first scholarly assessment of this tendency, Ferdinand Brunetière's article L'Impressionisme [sic] dans le roman (1879). The French critic, however, made a point of distinguishing thematic parallels in painting and writing from possible methodological analogies: «transposer le sujet est une chose, transposer les moyens d'expression en est une autre» (Brunetière 1879: 456, italics in the original; «transposing the subject is one thing, transposing the means of expression is something else»), and came to the conclusion that it was precisely the transposition of painterly «moyens d'expression» (Brunetière I879: 452) to writing that created literary impressionism.

More than a century later, Hans Lund adopted the same view on literary impressionism's relationship to the visual arts. On the subject of the Danish writer Klaus Rifbjerg's poem Monets åkandebilleder (Monet's Water-Lily Paintings), published in I970, Lund (I993: II8-I9) discussed the possibility of interpreting literary impressionism as a verbal transformation of a painterly theme. He resolved, however, that even an explicit allusion to works of art (such as the water-lily paintings in the title of Rifbjerg's poem) might transcend an ekphrastic discourse, and also that an ekphrastic reading of a subject treated by the impressionist painters is not automatically to be considered literary impressionism. Perfectly in line with Brunetière's rea- 
soning, according to Lund (I993: II9) textual impressionism comes forth only as the author activates a strategy to transfer to words the impressionist character of a pictorial composition. Following the Swedish scholar's reasoning, we may assume that Rifbjerg's curious poem might well be a case illustrating the impact of impressionism on literature, but does not account for literary impressionism.

When suggesting that literary impressionism occurs in texts in which the inspiration from impressionist painting is more methodological than nominal, one enters the field of comparative arts and, with that, a whole array of problems that concern the comparison between differing medias. Hans Lund (I982: 22-23) has described the dangers lying both in establishing purely associative analogies between literary works and the visual arts, and of metaphorically adopting the art critics' terminology when discussing literature. In addition, and in spite of Brunetière's early dictum, investigating pictorialism and iconic dimensions in the texts of writers concerned with impressionism is not rarely, even in the international debate, seen as a naif and insufficient approach to the issue of literary impressionism - or, at best, accepted with reservation. Exceptions are few ${ }^{\mathrm{I}}$.

Nevertheless, even a scholar like Mary Elizabeth Kronegger - who has dedicated years of her academic life to the examination of literary impressionism - while marking her distance from impressionist prose as a form of writing building on the idea of painting as intertext, she cannot resist establishing loose parallelisms between the art of Whistler and the one of

I Among the exceptions is Joy Newton, who has investigated cases of transpositions d'art in the prose of Zola, whom the scholar defines as «an Impressionist word-painter» able to transform canvasses into novelistic incidents (Newton I973: 325). In a survey of literary impressionism and French literature, J. Theodore Jr Johnson has given attention to those scholars who have tried «to relate brushwork and the handling of color in impressionist pictures to literary impressionism (Moser, Hatzfeld, et al)» (Johnson I973: 287). When Richard Berrong argues for the appropriateness of comparing Pierre Loti's I886 novel Pêcheur d'Islande to Monet's canvasses, his emphasis is primarily on questions of style: «like its painterly counterpart, literary impressionism must be primarily a matter of style and not just of content. Artists long before the Impressionists painted landscapes, clouds, seascapes, light, etc., but none of them would be considered Impressionists. It is their style that distinguishes Monet and his colleagues from their predecessors and successors, not their subject matter» (Berrong 2006: 226, italics in the original). Within the Scandinavian context Bernt Olsson (1983: 5-6), among others, argues for a direct influence of impressionist painting on Vilhelm Ekelund's poetry. With reference to anachronistic analogies in Hatzfeld (I952) and Sypher (I960), Hans Lund (I982: 99-I00) warns against the risk of over-interpretation when attempting to tie the visual dimensions of a text to specific painters or artistic movements. However, as Lund (I982: IOI-O2) moves on to a quotation from J.P. Jacobsen's novel Niels Lyhne from I880, in order to point out the characteristics of the passage that draw close to the impressionist canvasses of Monet or P.S. Krøyer, he seems to admit the usefulness of a similar approach. More recently Virginie PouzetDuzer (2013: 227-42) has returned to discuss the question of ut pictura poesis in relation to literary impressionism and several contributions to the conference proceedings from the festival Normandie impressionniste assess interart transpositions as well as affinities in style and motifs, see Gengembre, Leclerc, and Naugrette (2012: I7-43, I25-66). 
Mallarmé, or between Monet's technique and that of Verlaine and Rimbaud ${ }^{2}$. On Whistler's Portrait of the Artist's Mother: Arrangement in Grey and Black from I872, she comments (I973: 95): «this tonal painting compares with his friend Mallarmé's fondness for alliteration; the tenets of their aesthetics are allusion and suggestion». Similarly, Monet's Régates à Argenteuil, from the same year, calls forth the following observation: «the color oscillation of blues, whites, and reds induces the same sensuous pleasure as the arrangement of consonants and vowels in the poems of Verlaine [...] and Rimbaud [...] with musical-pictorial moods in which sonorous words take the function of colors» (Kronegger I973a: IOI).

If anything, these statements call to mind the plagued associative method that most scholars of comparative arts find of poor use and, consequently, the importance of making an effort to find out how Brunetière's dictum of a 'systematic transposition' of the impressionists' painterly moyens d'expression to writing really might work. How can we discuss writerly attempts to transfer to words the impressionist character of a pictorial composition? What narrative strategies are really involved 3 ?

Through the example of the Finland-Swedish painter and writer Helena Westermarck, who admired the impressionists and grew familiar with their art during her Parisian sojourns in the first half of the I88os, I will now

2 Cf., Kronegger (I973a: 93); «we do not claim that literary impressionism was a matter of writers deliberately trying to transpose into their medium effects achieved in the other art forms».

3 The few studies exploring the affinity between impressionist painting and lyrical poetry with reference to Swedish literature all seem to suffer from this loose associative method. The landscape poetry of Swedish authors such as Vilhelm Ekelund, Ola Hansson, and Per Hallström, has been equated with the articulation of colour and light in impressionist pictorial compositions, but these investigations undoubtedly remain at a superficial, evocative, level. See for example chapter five, entitled Impressionistisk och symbolistisk form. Två dikter av Vilhelm Ekelund (Impressionist and Symbolist Form. Two Poems by Vilhelm Ekelund) in Malmström I968: I32-52; Rolf Arvidsson's discussion of the relationship to impressionism and plein air-ism in Per Hallström's and Ola Hansson's poems (Arvidsson I969: II2-29); the aforementioned Karl Erik Lundevall's brief and almost reluctant discussion of impressionist qualities in Ola Hansson's poetry (Lundevall I953: 244-45); and Bernt Olsson's attempt to show how Ekelund painted impressionist landscapes in his poems, in the essay Ord hur fattiga. Vilhelm Ekelund och spräket (Olsson I983; Words How Poor. Vilhelm Ekelund and Language). A lack of factual connections is also, as I see it, the trouble with Florence Goulesque's essay Impressionnisme poétique chez Marie Krysinska: Esthétique de l'ambiguité et démarche féminine (Poetic Impressionism in Marie Krysinska: The Aesthetics of Ambiguity and the Feminine Approach), which presents Krysinska's «effets de lumière, [...] impressions changeantes, [...] rêveries esquissées» (3I9; «light effects, [...] changing impressions, [...] sketched dreaming»), her «mondes flous» (322; «indistinct worlds»), or her way of representing «une même scène [...] à différents moments de la journée ou sous divers conditions atmosphériques» $(324$; «the same scene [...] in different moments of the day or in diverse weather conditions»), vaguely as «répondants poétiques de l'art impressionniste» (322; «poetic correspondents to impressionist art»), while other aspects of her poetry are said to evoke «les thèmes et variations d'une fugue baroque» (325; «themes and variations of a baroque fugue»), or similarities with symbolists and decadents (330). In a recent article on Paul Verlaine, Nicolas Wanlin attempts to establish the grounds on which the analogy between impressionist painting and poetry may be founded (see Wanlin 20I2). 
proceed to address the issue investigation by departing from the idea of impressionism in literature as a transpositional prose that aims at reproducing impressionist painterly compositions through the medium of words ${ }^{4}$. By examining narrative elements such as iconic projection, framing, and the arbitrary cropping in her short story Aftonstämning, which shares the motif of the balcony view of a streetscape with many examples of impressionist art, I will argue that this Doppeltbegabung tried in prose what she had seen in painting.

\section{I. AFTONSTÄMNING: THE VERBAL RE-MODELLING OF THE IMPRESSIONIST} CITYSCAPE

Unlike H. Peter Stowell, who, as an exponent of Dumora's second interpretive trajectory, claims that the subjects of the literary impressionists «were not the water, snow, blossoms, clouds, sailboats, crowds, steam, speed, and mist of the painters» but «the impalpable surfaces of sensory data that attack consciousness» (Stowell I980: 49), I will argue that one of the ways in which impressionism was translated into literature was through adapting to language the motifs of the painters, and, most crucially for the purposes of this investigation, I will look at the extent to which this adaptation also involved a 'systematic transposition' of the means of the art of painting to the art of writing. A study of Westermarck's narrative techniques will, I believe, help to clarify what this, not all that intelligible, Brunetièrian verdict might encompass.

My chief concern in what follows will be the attempt to examine the short story Aftonstämning as a verbal representation of a motif familiar to impressionist painting, namely the balcony view of a Parisian streetscape. The point at issue here is to set up an interart analogy through the evaluation of a parallel motif, primarily, and parallel methods of composition in painting and writing, secondarily. Since the aspects of visuality in the text will be examined as a response to impressionist painting and its rules of composition, I will first briefly try to evaluate what impact the French impressionists

4 Helena Westermarck (sister of the internationally renowned cultural anthropologist Edvard Westermarck) was born in Helsinki and trained as a painter both in the Finnish capital and in the Parisian académies Trélat and Colarossi. Using the signature ' $\mathrm{H}-\mathrm{a}$ ' she contributed with art and literary criticism, as well as with short stories, to the review Finsk tidskrift in the years I879-94. The twelve short stories that make up Ur Studieboken I (I890c) and II (I89I) account for her debut as a writer, while several novels followed around and after the turn of the century. Westermarck also dedicated biographies to Finland-Swedish writers and artists such as Fredrika Runeberg, Fanny Churberg, and Maria Wiik. As co-founder and secretary of the women's association Unionen (The Union), she worked to sustain women's rights and divulged her ideas and opinions in the association's monthly review Nutid (Contemporary Age), of which she was editor. Her autobiography, Mina levnadsminnen (Westermarck I94I; MY Memoirs) was published posthumously in I94I. For biographical information see also Forssell I999: 46I-63, and Konttinen I996. 
had on Westermarck, and then look at her own idea of the analogy between painting and writing, before focussing on the interart dialogue at play in her short story through a close reading of the text. As I see it, the pictorial motif of the bird's eye view of Paris functions as an «ekphrastic model» (Yacobi I995 and I998) in a piece of prose that draws on specific «markers» (Lund I982: 36-38), which appear to address the aesthetics and the compositional strategies of the impressionist painters. If the coincidence of impressionist motifs in art and in literature is, as I believe, worth the attention of the one who wishes to capture the breadth of this 'ism', Westermarck's short story then also helps to inform us on the history of the reception and comprehension of impressionism in literary works written in Swedish.

\subsection{WESTERMARCK AND IMPRESSIONISM}

Helena Westermarck's observations on the impressionist movement can be found in four different source texts: (I) in a letter to her mother written in Paris on 4 April I880 (Westermarck I880); (2) in the articles Från Parisersalongen 1884 (From the Paris Salon 1884) I and II, which appeared in Finsk tidskrift that same year (Westermarck I884a and I884b); (3) in a short story entitled I marginalen af en museikatalog (Westermarck I89ob; In the Margins of a Museum Catalogue); (4) as well as in her autobiography Mina levnadsminnen (Westermarck I94I). These sources illustrate how Helena Westermarck moved from the initial perplexity common among the first beholders of impressionism to embracing the ideals of the movement and overtly paying her homage to the Dane P.S. Krøyer, who went through an impressionist phase. In a manner not much different from the changes observed in Strindberg's attitude to impressionism previously commented on, Westermarck, when writing her autobiography in the I920s and I930s, no longer mentions the early bewilderment confessed in her I880 letter home. Instead, she now presents herself as an admirer of the impressionists right from the start, as in the following passage from Mina levnadsminnen, which refers to the time of her second visit to Paris in I884:

Det hände att vi återsågo tavlor som vi fordom ställt ofantligt högt, men som nu tycktes oss bleknade och ointressanta. - Var det inte mer än så? hände det att vi tänkte. Andra åter stego fram i den nya fördelaktiga belysning tiden skänkt dem. Särskilt kommer jag ihåg salen med impressionistiska teckningar och målningar i le Luxembourg, där mycket nytt kommit till. Impressionisterna hade alltid haft stor lockelse för mig, därom bär redan min [...] tidningsartikel från I884 vittnesbörd. (Westermarck I94I: 336) 
Occasionally we went back to see paintings that we had earlier praised highly, which now appeared pale and uninteresting to us. - Was that all? we thought at times. Others reappeared in the new flattering light that time had brought to them. I especially recall the room with impressionist drawings and paintings in le Luxembourg, where much novelty had been added. I had always felt greatly drawn to the impressionists, as my [...] article from I884 already testifies.

When further discussing her taste in art, Westermarck (I94I: Io6) makes mention of her fascination for the old masters present in the Louvre (Teniers, Rembrandt, and Holbein) as well as for the «divine art» of Titian, Veronese, and Murillo, although she states, in conclusion, her conviction that «lärdomarna och de livgivande impulserna skulle dock hämtas från den moderna franska konsten» (I94I: I85; «the learnings and the vital impulses were nevertheless to be drawn from modern French art»). That «modern French art» is to be identified with the impressionist experience and with the fashion of plein air seems confirmed by several entries in the autobiography dedicated to the trends on the Parisian art scene at the time of young Westermarck's two sojourns in the French capital, in I879-8I and in I884:

Friluftsmåleriet - plein air - stod vid denna tid högt i kurs. Impressionisterna hade infört det med hela färgskalan ute i ljuset och solen, där alla reflexer kunde bryta sig mot varandra och åstadkomma det mest förvånande färgspel. Det var ju också något verkligt nytt som därmed fördes in i konsten. [...] Nu slogs dörren till atéljen upp, och konstnären gick ut till sol eller skugga eller till den mycket fint förtonande gråvädersstämningen. [...] Friluftsmålningen både då det gällde figurer och landskap fick ju en utomordentlig betydelse för konstnärerna i alla länder. (Westermarck I94I: 207)

Plein air painting was greatly appreciated at the time. It had been introduced by the impressionists along with the entire colour chart outside in the light and in the sunshine, where the juxtaposition of reflections could create the most amazing play of colours. Something completely new had really been introduced into art. [...] The door to the studio was opened and the artist walked out to sunshine or shade or to the delicately shadowed atmosphere of grey skies. [...] Painting both figures and landscapes in the open air really had an enormous impact on artists in all countries. 
During her years in Paris, Westermarck was especially drawn to plein air painting in the suburban outskirts still untouched by industrialization, such as Fontenay-aux-Roses and St. Cloud (Westermarck I94I: 136). She also spent the summer of I884 in Bretagne, dedicating herself to painting in the open air. In Mina levnadsminnen, she states that it was precisely the novelty of the impressionist movement and its plein-airism that attracted the Scandinavian artists to Paris in the I88os and early i89os:

Den franska konsten var för de nordiska konstnärerna mönstret och föredömet med den impressionistiska förnyelsen och plein-air-måleriet i Frankrikes mjukt förtonande luft, så olik nordens klara och skarpa med de starka färgmotsättningarna. (Westermarck 194I: I83)

The French art with the impressionist renewal and the plein air-painting in the softly nuanced air of France, so different from that of the North, harsh and clear with its sharp juxtaposition of colours, was the norm and the model for the Nordic artists.

In Westermarck's autobiographical writing, Paris thus comes forth as the point of convergence of the forces that triggered the new European art, and as an important source of inspiration not only for the Scandinavian painters but also for the writers (Westermarck I94I: 300) ( $^{5}$ As the relation between the 'sister arts' in the instance of Westermarck is never one of conflict but always of affinity, it has become something of a critical commonplace to stress the importance of the visual arts for her literary creation ${ }^{6}$. Likewise, Mina levnadsminnen sustains the opinion that Westermarck neatly refused a separation of the two forms of art, and bears witness to her conviction that the pen and the brush were to be used to express the same ideas (Westermarck I94I: 240, 255, 28I). On the subject of her prize-winning novel Lifvets seger

5 On the importance of Paris for Scandinavian writers at the turn of the nineteenth century, see Briens 2010 .

6 Cf., Estlander I89I: 57 and Konttinen I996: 22-24. Erik Ekelund states that the title of Westermarck's debut, Ur Studieboken, connects «både till hennes verksamhet som målarinna och till den litteraturart, den korta, skissartade studien, som var så modärn under hennes ungdomstid. Vi finner här realistiska ögonblicksbilder från muséerna, ateljéerna och artistkotterierna i Paris, men berättelserna ger också måleriska stads- och landskapsvyer» (1969: 348; «both to her activity as a painter and to a type of literature, i.e., the short, sketched study, that was so modern in her youth. What we find here are realistic instantaneous flashes from museums, ateliers and artistic groupings in Paris, but the stories also offer painterly views of cityscapes and landscapes»). Forssell claims that «författarinnans anknytning till bildkonsten märks tydligt $i$ hennes landskapsbeskrivningar där linjer och valörer har en viktig roll. Hon skildrar också unga kvinnliga konstnärer i flera noveller och i romanerna Framåt och Vandrare» (I999: 46r; «the author's connection to the visual arts is evident in her landscape descriptions, where lines and hues play an important role. She also depicts young women artists in several short stories and in the novels Framåt [Forward] and Vandrare [Wanderers]»). 
(Life's Victory), written in Italy in 1889 , she emphasized the interart dialogue present in the text. In this case, however, it was the art of the ancient Florentine masters that, almost unconsciously it would seem, had informed the novel:

Jag tror också att detta mitt ständiga umgänge med den gamla florentinska konsten - modern italiensk konst kom jag här alls icke i beröring med - fick ett alldeles bestämt inflytande på den berättelse jag höll på att skriva under min vistelse i Firenze, nämligen Lifvets seger. Medvetet eller omedvetet kom, tror jag, vid skildringen av personerna i min bok något av den stränga linjen från tavlorna och freskerna, som jag här ständigt såg för mina ögon, in i det jag då skrev. Man har senare någon gång påpekat en viss stramhet i framställningen. Själv har jag för övrigt aldrig kunnat göra någon fullständig åtskillnad mellan att måla och skriva. Det kan förefalla obegripligt, men i själva verket höra ju linjer och färger, tankar och ord mycket nära tillsammans. - Det var i synnerhet då jag under sommaren efter min hemkomst slutförde utarbetandet av boken, [...] som jag tyckte mig varsna ett visst sammanhang eller inflytande av de lärdomar jag vunnit med ögonens tillhjälp. (Westermarck I94I: 28I)

I also think that my constant exposure to the ancient Florentine art - I did not see any modern Italian art at all here - decidedly influenced the tale I was working on during my stay in Florence, namely Lifvets seger. Whether consciously or unconsciously, I think that something of the severe contours in the paintings and frescoes which I constantly had before my eyes, entered the description of the characters in my book as I wrote. Subsequently, there were occasional comments on a certain severity in the descriptions. I have never myself been able to distinguish neatly between painting and writing. It may seem incomprehensible, but lines and colours, thoughts and words really do belong quite closely together. - During the summer after my return home as I was finishing the work on the book, [...] I especially felt that I could perceive the analogy or the influence of the things I had learned with the help of my eyes.

\subsection{THE EKPHRASTIC MODEL}

There are, to my knowledge, no comments by Westermarck herself to support a reading of Aftonstämning that would associate the verbal art in 
the short story with the visual art of the impressionists. How, then, do we approach a text that evokes a recognizable and established painterly motif without indicating a specific pictorial counterpart to the reader? Would it be useful, or even possible, to award ekphrastic status to the passage depicting the panoramic view from above a Parisian street, which opens and sets the tone for the narration?

The definition of ekphrasis has shifted greatly from the ancient idea of a «vivid description of visual impressions, including landscapes, architectural constructions, battles, plagues, etc» (Klarer I999: I-2) to the modern implication of a double representation, i.e., a «verbal representation of a visual representation» (Heffernan I991: 299 and I993: 3). In most studies dedicated to ekphrasis, it seems clear enough that at the core of the modern ekphrastic practice is the very 'reference' to a generic model or to a specific work of art, be it existent or fictitious (Clüver I997: 3I). Among the recent voices arguing for an extensive use of the contemporary definition of ekphrastics as «modes whereby texts engage with visual culture» (Harrow 20IO), or as forms of language that «make us see», as in Mitchell's idea of «ekphrastic hope» (Mitchell I994: I52-I54), Tamar Yacobi's discussion of the poetics of ekphrasis stands out. If the omission of references to a unique artwork or to a whole set of paintings disengages Westermarck's short story from the traditional ekphrastic discourse, Yacobi's concept of ekphrastic, or pictorial, models runs to the rescue in the process of interpretation and comprehension of a tale more statically descriptive than narrative. Yacobi (I995 and I998) describes the pictorial model as a «neglected form» (Yacobi I998: 23) of ekphrasis and as a «visual stereotype» (Yacobi i998: 33), which does not choose a specific work of art for verbal rendering but makes use of multiple visual sources and generalized references to artistic themes, styles, or topoi.

In the case of Aftonstämning, investigating those passages that «act like pictures or "incorporate" pictorial practices» (Mitchell I994: 4), and raising questions about the interaction between the text and the rules of composition in impressionist painting, serve to illuminate Westermarck's evocation of a certain atmosphere that not only expert readers are bound to perceive as characteristic of the age in which the short story is set, and may also enrich our understanding of the way in which the author combined form and content in her writing. If Westermarck seems to strive to avoid the overly anecdotal, concentrating instead on mediating reality through picture-like description, at the feeble narrative core of a story - in which the viewer's gaze, oscillating between high and low, interior and exterior, private and public space, is the true protagonist - is a seamstress, a character belonging to the urban working class, here described in terms reminiscent of naturalistic prose. As part of the urban working class, the seamstress is one of many «arbetets martyrer» (Westermarck I89oa: 34; «martyrs of labour»), 
whose sporadic day off is synonymous with «frihet, lycka och lifsglädje» (Ibidem; «freedom, happiness, and joie de vivre»), as opposed to the idleness associated with the leisure time of the wealthy bourgeoisie, as we will see. While thematic concentration is on a narrow, lower-class side street in the Étoile-quarter (rather than on the sophisticated Haussmannian boulevard right around the corner) and on a seamstress's day off (in place of the recreational time of the higher classes), it is significant that the representational mode should reveal the author's interest, not in 'objective' naturalism, but in an impressionist reading of the Parisian cityscape. What is more, if the impressionist painters turned away from the tensions and ills of contemporary society, Westermarck's way of casting a social message (i.e., the juxtaposition of the bourgeoisie and the working class) in a very modern form, appears to mirror the Scandinavian artists' tendency to blend naturalism and impressionism into an art of the middle way.

Riitta Konttinen has spoken of the conceptual confusion that prevailed in the Finnish art circles of the I88os where naturalism was, on the one hand, made synonymous with impressionism and referred to as a «klatschmanér» («blotched manner») and, on the other, employed to designate the 'dangerous' novels of Zola (Konttinen I996: 4-5)7. Margareta Gynning explains the middle way assumed by the Scandinavian women painters in Paris in the I880 as an art that grew out of the example of the painters of the juste milieu (BastienLepage, Sargent, and Edelfelt, among others); artists who displayed a visible influence from the urban flânerie present in Manet and in the impressionists, in spite of their classical education. Next to the male flâneur, Gynning writes, the female impressionists took to those aspects of modernity to which they had access and painted modern life from the balconies, choosing a perspective that obliged the viewer to consider the city from a point of view different from the one usually assumed by men roaming the city streets (Gynning I997: 42-43). Although it must be added that the domestic flânerie from the balcony was by no means exclusively feminine (as is demonstrated by the many variations on the homme au balcon-theme in, for instance, Caillebotte, Monet, Pissarro, Krohg, or Munch), Gynning's comment is relevant to our discourse, as I will try to demonstrate below. So is her observation, which coincides with Helena Westermarck's own memoirs, that the freedom which the continental metropolis had to offer young women painters in the I88os, did not include spending time unchaperoned in the streets, ballrooms and cafés (Gynning I997: 42). Westermarck, however, claims to have been quite indifferent to studying the life of the people in night cafés and ballrooms, and maintains that the kind of social studies that attracted her the most were occasions like the one that brought her to attend a speech given by the formerly exiled communist Louise Michel (Westermarck I94I: I36-37).

7 Helena Westermarck (I880) herself uses the definition «klatschmanér» to describe the art of the impressionists in the letter to her mother from Paris, 4 April I880. 
In the absence of authorial commentary to support the legitimacy of an interart comparison in the specific case of Aftonstämning, my conviction that Westermarck's textual decoding of Paris is formed by impressionist art is founded on the author's choice of subject and point of view, as well as on the instructions offered by the storyteller to heighten the reader's awareness of the type of pictorialization that the urban environment and the window motif undergo in the narration. Not only is pictorial allusion quite evident to those readers able to decipher the interplay between the text and the repertoire of the impressionist painters, but it is also signalled by the fictional perceiver, who coincides with the narrator. I will motivate the relevance of a comparison between the text and the visual sources of the impressionists through a discussion of the motif and of the painterly structures present in the narration.

That the bird's eye view of Paris from a balcony or from the window of an atelier was a favourite among the impressionists is something to which the canvasses of the painters who came into contact with the movement at some point of their career bear witness: Monet's two versions of the Boulevard des Capucines in the early i87os (fig. I) or his Rue Montorgueil (1878) with its flying flags; Caillebotte's Rue Halévy, vue d'un sixième étage (I878; Rue Halévy, Seen from the Sixth Floor, fig. 2) and his many versions of the Boulevard Haussmann painted around I880, such as Un Balcon, boulevard Haussmann (A Balcony, boulevard Haussmann, fig. 3); Homme au balcon, boulevard Haussmann (Man at the Balcony, Boulevard Haussmann, fig. 4); Un Refuge, Boulevard Haussmann (A Traffic Island, Boulevard Haussmann, fig. 5); Boulevard Haussmann, effet de neige (Boulevard Haussmann, Effect of Snow, fig. 6) or Boulevard, vu d'en haut (Boulevard, Seen from Above, fig. 7); Pissarro's Boulevard Montmartre (I897), caught in different moments of the day and in different weather conditions, and his Rue St. Lazare (1893) and Avenue de l'Opéra (1898, fig. 8), as well as Edvard Munch's Rue Lafayette (fig. 9) and Rue de Rivoli (fig. Io), both painted in I89I, to name just a few. The search for a singular perspective that would allow the beholder an oblique and extraordinary view of a fraction of the urban reality was in line with the impressionists' general break-up with the traditional rules for composition. The structural schemes of the impressionists depended both on the influence of the graphic organization in the much admired Japanese prints, as well as on the often drastic and haphazard framing brought about by contemporary photography, of which Nadar, who had hosted the first impressionist exhibition in his atelier in rue des Capucines, was a forerunner. Nadar's photographic excursions in the hot air-balloon Le Géant had shown the painters new points of views and encouraged them to observe the city from above.

Helena Westermarck's writing of the city seems to draw on precisely the 
same visual experience as she opens her story with a balcony perspective of the urban scene and underlines the boldness of this viewpoint through the observations of the effects that a sharply oblique angle of vision has on the perception of the human figures down below:

Solen hade hela dagen baddat brännande och bländande i de långa avenuerna och kommit gatan med dess fina lager af stoft att skifta i hvitt. I slutet af avenuen sågos träd, gata och hus svepta i en gråaktig dimmig ton, och en bit af himmelen upp öfver altsammans fick ett lätt rökfärgadt flor öfver sin blå bottenfärg. [...] Från femte våningens balkong kunde man se hela gatan $\mathrm{i}$ fågelperspektiv. Allra nederst syntes människorna i underlig förkortning, mest bara hufvud och armar. En krans af barnhufvud, från den ljusaste gula skiftning till den mörkaste svarta, svängde om midt på gatan efter en dragharmonikas gälla toner. Stolar och bord hade blifvit flyttade utanför dörrar och portar. Där sågs en massa hufvud; några i hvita mössor och fladdrande bjärta band voro i ständig rörelse, de tillhörde kokerskorna, som efter att hela den heta dagen i ända hafva stått vid en glödande spisel, nu svalkade sig en stund där ute. Här funnos ärevördiga gråa hufvud i kalotter, till hvilka hörde hvita skjortärmar och ett moln af fin grå rök ur tobakspipan; gråhåriga slätkammade hufvud under yfviga svarta spetsmössor, och med dem följde ett par flinka knotiga händer, som raskt rörde strumpstickorna. I dörren till vinkommersen skockade sig en hel hop svarthåriga hufvud på brunbrända breda nackar, och bara seniga armar eller blåa blusärmar gestikulerade ifrigt. Ibland [...] stack sig mellan de korthåriga karlhufvudena med de skarphuggna profilerna fram ett annat hufvud med mjuka konturer, och ett blondt krusigt hår glänste till i ljusskenet, som föll inifrån. (Westermarck I89oa: 25-28)

The hot and blinding sun had been hitting the long avenues all day and made the street with its thin layer of dust turn to whiteness. At the end of the avenue, a hazy greyish shade could be seen to envelop trees, street and buildings, and the blue foundation of a piece of the sky visible on top of it all was shrouded in a slightly smoky veil. [...] From the balcony on the fifth floor the whole street could be caught in a bird's eye view. The people at greatest distance were strangely shortened, not much more than mere heads and arms. A garland of children's heads, from the fairest shade of yellow to darkest black, was moving around the street to the shrill sounds of an accordion. Chairs and tables had been arranged outside doors and gates. Countless heads 
could be seen; the ones in white caps and fluttering ribbons were continuously on the move, they belonged to the cooks, who had spent the whole day in front of a glowing stove and now were out for a nip of fresh air. There were distinguished grey heads in caps, to which white shirtsleeves and a cloud of fine grey smoke from the tobacco pipe belonged; there were well-combed grey heads underneath wide black lace bonnets, and these were accompanied by agile worker's hands, quickly twisting the knitting needles. In the doorway to the wine shop a crowd of black-haired heads on top of large, suntanned necks gathered, and bare, sinewy, arms or blue shirtsleeves were keenly gesticulating. At times [...] another head with soft contours peeped out among the short-haired heads of the men with their severe profiles, and its blonde curly hair gleamed in the light coming from inside.

This textual presentation of the cityscape - with its accent on colours and on various atmospheric effects, as well as the meditation on the peculiar foreshortenings of the human body - is on its own clearly image-oriented. Nevertheless, it is the plunging perspective from a window opening onto an unhindered vision of a street bustling with life that delivers the scene as an impressionist motif. According to Virginie Pouzet-Duzer, the occasional angle of vision may indeed in itself make up for the impressionist character of a painting. On the subject of Caillebotte's Rue de Paris: temps de pluie (1877; Parisian Street: Rainy Weather), Pouzet-Duzer comments: «ici, plus que la peinture en-soi, le choix d'un cadre, d'un angle de vue original constitue le caractère impressionniste $d u$ tableau» (Pouzet-Duzer 2008: 237; «here, more than the style of painting itself, it is the choice of framing, of an unexpected point of view, that makes up for the impressionist character of the painting»).

The diagonal perspective does not remain fixed throughout Aftonstämning, but the focus changes as the balance almost imperceptibly tips from description to narration: the gaze of the speaker-perceiver moves upwards from street level to the first, second, and third floor of the building on the opposite side of the street, again without forgetting to comment on the effects of the point of view on the appearance of objects and people, as if the scene was to be drawn rather than registered in words: «ju högre blicken steg, dess mindre blef förkortningen» (Westermarck I890a: 28; «the higher up the gaze moved, the lesser was the effect of foreshortening»). Looking in through a window on a bourgeois family interior on the way upwards, the beholder pauses to fix an image of domestic comfort and cosiness. For an instant, the narrator stops to outline the new subject of the modern painters, the leisure time of the bourgeoisie: monsieur reading the evening paper, madame by the lamplight occupied with her needlework, mademoiselle at the 
piano and the young master riding on a chair in front of a pile of books. At last the gaze conquers the top floor of the building to catch a glimpse of the tenants standing outside to get some fresh air, while presumably looking down on the city:

en hvar, som hade en balkong, ett fönster eller till och med blott en liten glugg, försökte skaffa sig frisk luft; ända ut på taken med de gigantiska skorstenarna och rökrören, som stå i rader likt omstjälpta blomkrukor, syntes folk. (Westermarck I89oa: 29)

everyone who had a balcony, a window or even just a small skylight, attempted to get some fresh air; people could be seen all the way out on the rooftops where giant chimney stacks and flue vents stand aligned like overturned flowerpots.

The wandering eye reaches its goal when detecting an open window behind the arabesques of a small wrought iron balcony opposite its own:

I femte våningen tvärs öfver den trånga gatan midt emot mig voro fönstren uppslagna till en liten balkong, hvilken var omsluten af ett järnstaket och en barrier med långa utstående järntaggar, där grannens andel af balkongen vidtog. Här stod en lång rad af blomkrukor med skott och sticklingar i, samt smala trälådor, ur hvilka stockrosorna stucko snedt fram i vädret och trängde sig ut mellan staketets galler för att snappa upp några solstrålar. (Westermarck I89oa: 29-30)

On the fifth floor on the other side of the narrow street, right across from me, the windows stood open to a small balcony surrounded by an iron railing and a barrier of long iron spikes where the neighbour's part of the balcony began. There was a row of flowerpots with shoots and cuttings and narrow wooden boxes, out of which hollyhocks sprouted obliquely into the air and jostled through the balcony grille to catch a few sunbeams.

Although nothing has yet been revealed about the tenant living en face, the flowerpots and the growing roses evading through the iron railing are details that suggest what Pouzet-Duzer calls «l'espace [...] féminisé du balcon» (2008: 244; «the feminized [...] space of the balcony»). Pouzet-Duzer furthermore reads the grilles that frequently surround railroads, balconies, and women - not least - in impressionist compositions as elements that emphasize a woman's impossibility to conquer the alluring, and apparently boundless, city space offered by the often depicted new boulevards: «qu'il 
s'agisse des grilles du chemin de fer, de celles des balcons, du jeu des piliers et des miroirs des perspectives de Degas [...], on retrouve en effet chez tous ces impressionnistes une représentation [...] de la femme comme entourée, enfermée, encadrée» (Pouzet-Duzer 2008: 24I; «whether it be the railings at the railway station or those on a balcony, or the kaleidoscopic effect of pillars and mirrors in Degas's perspectives [...], the representation [...] of women as surrounded, flanked, or hemmed in, is common among all these impressionists»). Thus, the motif of the femme à la fenêtre, which also happens to be the sad source of inspiration for Herman Bang's brilliant impressionist novel Ved Vejen, has very different connotations from the impressionist canvasses portraying men watching from the balcony or looking out of the window.

2.4.1. The technique: iconic projection, iconic lexicon, framing, and the arbitrary cropping

As portals to the outside, balconies and windows tell of space and of the delimitation of space, of boundaries and of the breaking of boundaries ${ }^{8}$. They also play an important part in those narrations that draw upon pictorial modes of description, as Hans Lund has shown in his discussion of the relation between visuality and literature. The concept of «ikonisk projicering» (I982: 53; «iconic projection») is, in the scholar's terminology, synonymous with reading a portion of the external reality as if it were an image. Iconic projection, as defined by Lund, covers both the fragment of reality that is being observed and the actual mode of description. As far as the latter is concerned, the modes of signalling an imagistic approach to the description of reality rely on «markörer»9 («markers»), that point to the relevance of a comparison between the verbal representation and a visual source, such as: (I) a terminology familiar to the description of artworks; (2) a perception typical of that of a painter; (3) an aesthetic distance to the scene described. One way of expressly achieving the desired aesthetic distance is through the use of physical frames such as doors and doorways, windows and window frames, which delimit the motif:

Med hjälp av den reella eller fiktiva ramen etableras den estetiska distanseringen och mobiliseras den kod som får betraktaren att

8 Interesting reflections on the symbolic value of gateways and windows are put forward both in Lund (I982: 54-59), and in Lykke (2000: 92-93). Balducci (2017: III-54) dedicates an entire chapter to windows and balconies in the canvasses of artists such as Manet, Caillebotte, Bonnard, Morisot, and others.

9 Lund (1982. 36-38) adapts Louise Vinge's coinage «markör» («marker») to designate a textual detail that activates «läsarens bildkunnande, bildtänkande och eidetiska förmåga» (Lund I982: I50; «the reader's familiarity with pictures, his visual thinking, and eidetic ability»). 
uppleva former, linjer och färger i sin optiska omgivning som element i en målning, en teckning, ett foto osv. Detta sätt på vilket betraktaren visuellt begränsar och omtolkar den yttre verkligheten är [...] något som man kan belägga i litterära texter från I7oo-talet och fram till idag. Författarens val av bildkod för textens ikoniska projicering [...] är givetvis beroende av det bildförråd, det ikoniska lexikon som författarens egen sociokulturella verklighet ställer till hans förfogande. Författaren kommer naturligtvis alltid att i hög grad stå under inflytande av tendenser i samtidens bildkonst och bildvärld, av samtidens sätt att uppleva och tolka den optiska verklighet som fastnar på näthinnan. (Lund I982: II9)

A real or fictitious frame helps to achieve the aesthetic distance and set in motion the code that makes the perceiver experience shapes, lines and colours in his optical environment as elements of a painting, drawing, photography etc. The perceiver's manner of visually delimiting and interpreting the external reality is [...] something that can be charted in literary texts from the eighteenth century and up until today. The author's choice of a picture code to support the iconic projection in the text [...] is certainly dependent on the storehouse of images, the iconic lexicon that his own socio-cultural reality presents him with. The author will, of course, always be greatly influenced by tendencies in his contemporary art world and artistic production, by the contemporary mode of experiencing and interpreting the optical reality that is projected on the cornea.

Framing through the use of windows and balconies is a frequently adapted imagistic approach to description in Aftonstämning. The following example, with its accent on the play of light, shadow, and artificial illumination, may be used to illustrate Westermarck's instances of pictorial framing in general:

Fönstren stodo öppna, och genom det yttre rummet, som var mörkt, föll lampskenet från det inre helt dämpadt öfver balkongen, som i denna belysning tog sig ganska ståtlig ut med alla sina grönsaker. (Westermarck I89oa: 30)

The windows stood open, and through the external room, which was dark, the lamplight from the inner room fell softly over the balcony, which in this light looked rather majestic with all its greenery.

That the attempt to make both narrator and reader experience the observed views as if they were painted representations is clearly part of the 
authorial intention, and it becomes obvious when an episode in the text is spoken of in terms of a framed canvas:

genom balkongens fönster och rummets dörr, som bildade likasom en mörk ram till den ljusfulla taflan där innanför, såg jag symaskinen undanstäld i en vrå samt min granne i lampskenet sysselsatt med att duka ett festligt middagsbord. (Westermarck I89oa: 3I)

through the windows of the balcony and the door of the room, which formed a sort of dark frame around the radiant painting within, I saw the sewing machine stored in a corner and my neighbour occupied with laying a festive dinner table.

While the above-mentioned examples no doubt represent instances of visual perception, they are, it must be admitted, no more and no less reminiscent of an impressionist representation than is the title of the short story, Aftonstämning. The title, too, appeals to visual thinking and designates the works of many Swedish painters such as Severin Nilsson (1846-I918), Carl Fredrik Hill (I849-I9II), or Wilhelm von Gegerfelt (I844-I920), among others. While it is certainly not contradictory to claim that those passages revealing the author's fascination for light effects and the play of reflexes must be attributed to the painter Helena Westermarck's eye, trying to anchor these paragraphs to the style of an epoch is hazardous. Indeed, although one of the chief concerns of the impressionists was to explore and try to capture the interaction between luminosity and matter, and the juxtaposition of outside and inside light, as in the case of the window theme, it must be convened that the details in the following description of light effects on cheap glassware and second-rate silver-plated cutlery are pictorial in a general sense rather than specifically impressionist:

Rödvinet glimmade i de simpla glasen och kastade oregelbundna röda fläckar på duken, när ljuset bröt sig igenom; vattenkaraffen lyste i lampskenet; alfenidskedarna och sockerskålen blänkte och kastade ut små knippen af kallt reflexljus. (Westermarck I89oa: 32)

The red wine glimmered in the plain glasses and threw irregular red stains on the tablecloth as the light broke through; the water carafe glowed in the lamplight; the teaspoons of alfenide and the sugar bowl glistened and emanated tiny shafts of cold reflected light. 
What the above-quoted segment really reveals are the elements on which Westermarck focussed as a painter: light effects, colour treatment, truthfulness to reality, all aspects, according to Konttinen, that indicate how this artist often seemed to accord more importance to the execution than to the motif (Konttinen I996: 26). How, then, is it possible to endorse the deduction that Westermarck anchors the visual readings of the scenes in the story precisely in the «iconic lexicon» of her time? ${ }^{\text {Io }}$

The age of impressionism offers an iconic lexicon that comes across as a storehouse of formal innovations such as snapshot-compositions characterized not only by odd and sharply oblique perspectives, but also by apparently arbitrary cuts, again reminiscent of the art of photography and of the popular Japanese prints. Helena Westermarck's prose shares the pictorial language of the impressionist compositions through the employment of peculiar framings when focussing both on the initial street scene of which the narrator only perceives details of the people, and on the events taking place in front. As the seamstress receives her dinner guests, a woman and a man, the narrator comments: «jag kunde endast se de hvita skjortärmarna och en profil med ett par svarta mustascher, resten skar dörrposten af» (Westermarck I890a: 3I-32; «I could only catch the white shirtsleeves and a profile with a couple of black moustaches, the rest was cut off by the doorframe»). Never once does Westermarck allow her narrator and the reader to catch a full-length portrait of the man who is being observed, but she always provides as much of him as can be seen from the speaker-perceiver's position. Within the given frame, glimpses of his profile appear and disappear, an arm is stretched out and the bluish smoke of a lit cigar blurs the scene.

As the dinner comes to its end and oranges are brought in for dessert, the portion of the man's body delimited by the frame has been reduced to a mere hand reaching out for the fruit: «af mannen syntes endast handen, som höll upp den ena skifvan efter den andra mot ljuset, doppade den i sockret och lät den försvinna» (Westermarck I89oa: 33; «what could be caught of the man was only his hand, raising slice after slice up against the light, dipping it into sugar and letting it disappear»).

When the Goncourt brothers in Germinie Lacerteux from I865 similarly treated a cow, cutting half of its body off in their description, the novelty of this framing technique was noticed by critics such as Louis Desprez and, as Hans Lund (I993: 46) has reminded us, the Dane Georg Brandes, who both established an intertextual parallel to painting. Desprez read the passage as reminiscent of the technique by which «un peintre ne réclame plus d'un morceau de ciel ou d'une moitié de vache, si ce morceau de ciel et cette moitié de vache suffisent à l'effet voulu» (Desprez I884: 87; «a painter does

Io Lund's notion of 'iconic lexicon' stems from Northrop Frye's coinage 'visual lexicon' and indicates, similarly, the image bank that any human mind has at its disposal according to its specific socio-cultural realities (Lund I982: II9, I73). 
not ask for more than a piece of sky or half a cow, if this piece of sky and that half a cow are enough to reach the effect desired»), which calls to mind the formulation of the philosophy of impressionism as a metonymic mode of description, which we will shortly take a closer look at ${ }^{\mathrm{II}}$. In his essay Edmond og Jules de Goncourt written in I882 Brandes, instead, explains the reference to art in the same piece of prose with an allusion to the ancient idea of the untutored eye reporting only what can be seen, never what is known: «naar deres Landskaber saa fuldstændigt gør Indtryk af Malerier eller Raderinger, saa beror det især paa, at de giver det Udsnit af Tingene, der har frembudt sig for deres Øjne, nøjagtigt som de har set det» (I90ı: II7; «as their landscapes to such an extent give the impression of paintings or etchings, it is specifically due to their way of offering a fragment of the objects in front of their eyes, precisely as they have been observed»). With a quotation in translation, Brandes then illustrates this opinion referring to the Goncourts' description of «half a red cow's body» and concludes: «en Forfatter af den ældre Skole som Sainte-Beuve havde ikke forholdt os Koens anden Halvdel. Disse Betragtere holder sig strengt til, hvad de ser» (Ibidem; «a writer of the old school, such as Sainte-Beuve, would not have omitted the second half of the cow. This kind of beholders only report what they see») ${ }^{12}$.

Again, the reference is to the 'primitive eye' that was adopted by the impressionists, to the idea, that is, of reproducing only what the eye perceives, unaware of what the mind knows a priori about the observed scene.

\subsection{CONCLUSION: FORM AND CONTENT}

In conclusion, a verbal representation merely sharing the motifs of the impressionists may not determine the impressionist character of a piece of prose but, in the case of Aftonstämning, markers such as the point of view, the odd framing, and the organization of the elements within the given frame, as well as the attention, in part, to colours and to light effects, testify to Westermarck's knowledge of the innovations in impressionist painting and push the interpretation of the text in the direction of a transformation of impressionist painterly structures into words ${ }^{\mathrm{I3}}$.

\footnotetext{
II See Metonymiske former in Møller Kristensen (I955: I23).

I2 In spite of the fact that Germinie Lacerteux was written years before the official birth of impressionism, Lund suggests that the interpretation of this passage, originally delivered in I882, «rör sig mycket nära de impressionistiska målarnas sätt att se» (I993: 46; «draws very close to the mode of perception of the impressionist painters»).

I3 'Transformation' is, in Lund's theorization, one of the three principal modes whereby word and image co-exist. Transformation occurs when a text aims at «gestalta en spatial karaktär eller transformera karakteristiska element ur en epoks eller en eller flera bildskapares ikoniska sfär. Ja, den kan till och med, utan att direkt anknyta till reell eller fiktiv bild, försöka överföra bildkonstens struktureringsprinciper eller stilkarakteristika till ordets form» (I982: I4; «giving form to spatial characteristics or transforming elements characteristic of an epoch
} 
In line with the late nineteenth-century Scandinavian understanding - or perhaps rather 'lack' of understanding - of impressionism, is also Westermarck's reflection on the social content of the scene, which really eludes the scope of much impressionist art. Not many impressionist canvasses are images suitable for narrativizing, i.e., pictures that 'tell a story'. Underlining the fact that the term 'impressionism' was coined to mirror the content of canvasses conveying nothing but sensorial perception - que des impressions! - the art historian Hans Ruin (I949: I6) comments as follows on this aspect of the movement: «varken etiska eller sociala intressen, som $i$ så hög grad låg under de föregående decenniernas naturalistiska måleri och diktning, är längre knutna vid konstverket» (I949: I6; «neither ethical nor social interests, which to a great extent had informed the naturalist painting and writing in the previous decades, are longer attached to the work of art»). The revolutionary novelty of the impressionists lay indeed, as has been observed, in the idea of freeing painting «from the tyranny of the anecdote, since their interest was not in the subject, [...] but in the handling» (Sypher i960: I72).

Westermarck's idea of choosing a flash of reality from impressionist Paris as point of departure for her narration is then somehow reversing the efforts of the impressionists to turn modern painting away from literature and storytelling. Also, the pictorial stasis and the 'lack of content' of this specific impressionist subject are both contradicted by the very nature of the act of narration. Westermarck's narrator may be observing the scene with the eyes of an impressionist painter, flirt with impressionist aesthetics and shun the anecdotal, but the reflections and the social interest that in the end are added to the description coincide with those that informed the naturalists. The view that releases the narration is, as has been observed above, that of a narrow street squeezed in between two large boulevards in the Étoile-quarter, where there are no top hats in view and where a carriage of the gentry very rarely, the narrator informs us, turns the corner. The bird'seye view may indeed increase the sense of distance to the scene, prevent involvement, and indicate a lack of penetration into the psychology of the fictional characters, but as Westermarck proceeds to close-up sections that concentrate on human themes, she resists the philosophy of l'art pour l'art that was gaining ground in the age of impressionism.

My argument then suggests that, as to form, Westermarck's short story counts as an example of literary impressionism. As to content, Aftonstämning should be read as a study in social types, whose diversity and separateness is accentuated by the vertical movement of the viewer's gaze, which underlines the social levelling and the disengagement of the bourgeois family in their apartment from the animated working class crowd below and the

or of the iconic sphere of one or several artists. It may, indeed, even try to translate the structural principles or the characteristics of style of the visual arts into words»). 
seamstress above. Westermarck's impressionism, both in the painterly and in the literary field, may contradict the lack of social messages characteristic of the French pioneers, but must be considered conventional within the context of the Scandinavian middle way ${ }^{\mathrm{I}}$.

I4 Cf. e.g., the discussions that followed the exposition of Westermarck's painting, En viktig fråga (1883; An Important Question), which encountered the hostility of the critics both because of the radical naturalism of the subject (two ironing women) and for its 'impressionism', cf., Konttinen (I996:5-6). Konttinen's definition of the painting as «Suomen taiteessa harvinainen kaupunkityöväestön kuvaus» (I996: 5; «one of the rare depictions of the urban working class in Finnish art»), reminds us of the fact that the very same topic interested Westermarck as a writer, just as the short story Aftonstämning proves. 



\section{$3 \cdot$ \\ THE NARRATIVE METHODS OF THE RENDERING OF IMPRESSIONS: STELLA KLEVE}

What, then, are the narrative characteristics of a writing that builds on the rendering of impressions? The question has been variously debated. Even a scholar such as Sven Møller Kristensen, who, as we have seen, departs from the idea that impressionist writing is the transposition into words of the methods and style of the painters, reflects on the second element of the coinage 'literary impressionism', and agrees that «det dybest gående træk i impressionismen er [...] undgåelsen af den logiske bearbejdelse af indtrykkene, manglen på analytisk virksomhed» (I955: II9; «the most essential trait of impressionism is [...] the avoidance of a logic systematization of the impressions, the lack of analytic work»). Consequently, his studies concentrate on how this fundamental impressionist feature regarding the act of perception comes forth through grammar (for example through the use of «substantivisk stil» [Ibidem; «nominal style»], or «parataktisk og koordinert sætningsbygning» [Ibidem; "paratactic and coordinated syntax"]) as well as through stylistic qualities on a higher textual level, which include, for example, the apparent absence of the author and the unobtrusive position of the narrator, indirect speech, stream-of-consciousness, phenomenological apperception, and metaphorical language. As mentioned in his foreword (I955: 13), Møller Kristensen's aesthetic and stylistic approach to literary impressionism is, not surprisingly, inspired by the early German formal and linguistic investigation of literary impressionism, as in Louise Thon's study Die Sprache des deutschen Impressionismus (Thon 1928), a methodology which has recently been judged outdone and unscientific, as previously mentioned $^{\mathrm{I}}$.

Earlier criticism commenting more or less briefly on Stella Kleve's impressionism (Dahlerup 1987; Ney I993a, I993b, 2005; Lingebrandt 20II)

I Cf. for example Virginie Pouzet-Duzer 2008: 7 . 
alludes - rather impressionistically, it must be said - to the author's transmission of instantaneous impressions in her prose, and also mentions the «nervousness» and «frenzy» observed in her prose as an impressionist trait (cf., Ney 2005: 106, Lingebrandt 20II: 70). The category of literary impressionism has furthermore been used to define the author's «holdning» (Dahlerup 1987: I49; «stance») or «livsuppfattning» (Ney 1993a: 152; «attitude towards life»). Conversely, taking into account the fact that Kleve herself actually felt comfortable with the definition of impressionist - a detail hitherto overlooked by scholars - I will investigate her impressionism by departing from similarities with the scenic method of her revered master, Herman Bang, and then look at what I see as the essential trait of her impressionist mode, namely a mode of apperception that, according to a phrase formulated by Kleve in her short story Pyrrhussegrar (Pyrrhic Victories), strives to represent people and objects as in 'a cracked mirror', only rarely allowing the emergence of a totality but steadily focussing on single details and elements that stand for the whole.

I will speak of this descriptive method as the 'metonymic' mode, a definition that draws on Kristensen's observations regarding the centrality of the figure of metonymy in impressionist writing. This is a narrative mode that, on occasions, blends with what is often spoken of as 'primitive perception' in studies concerned with impressionist writerly techniques, and becomes, at least in one instance, an example of what Ian Watt defines as 'delayed decoding' in his studies on the impressionist prose of Joseph Conrad. Both forms strive to render the process of perception by relying on an initial sense impression to which meaning is attributed by organizing the narrative description in terms not obeying logic or earlier perceptive experience. I will then argue that Stella Kleve's adoption of impressionist narrative modes, both scenic and metonymic, is far from being purely decorative and serves her choice of subject in that these become means with which to probe the improbable: the taboo of female eros.

\section{I. STELLA KLEVE AND LITERARY IMPRESSIONISM}

According to the consensus view (cf., Ney I993a: 33, Lingebrandt 20II: 7, Carlander 2013: 94) on the Swedish writer Mathilda Malling (I864-I942), the pseudonym, Stella Kleve, should be used to indicate the early, avant-garde phase of her authorship, located in the I88os. The writer's given name, Mathilda, in combination with the surname Malling - replacing her family name Kruse after her marriage, in I890, to the Dane Peter Malling - instead refers to the later (and less experimental) literary output, consisting mainly of the romantic historical novels that she published from I894 to I931. Not surprisingly, it is mainly Stella Kleve who has caught the inter- 
est of the scholars. Recent contributions to the small, but growing, body of critical commentary exploring the role of Kleve's writing on the late nineteenth-century Swedish literary scene comprise Birgitta Ney's doctoral thesis Bortom berättelserna. Stella Kleve - Mathilda Malling (Ney I993a; Beyond the Stories. Stella Kleve - Mathilda Malling), revaluating the author's place in Swedish literary history; Ann Lingebrandt's portrait of the artist as a counter-culturist, Stella Kleve. Det moderna genombrottets enfant terrible (Lingebrandt 20II; Stella Kleve. The Enfant Terrible of the Modern Breakthrough), and Cecilia Carlander's recent PhD dissertation Les Figures féminines de la décadence et leurs implications esthétiques dans quelques romans français et suédois (Carlander 2013; Women of the Decadence and Their Aesthetic Implications in Some French and Swedish Novels) ${ }^{2}$. Nonetheless, both Birgitta Ney (I993a: I83-200) and Ann Lingebrandt (200I: I33) comment that the cleavage separating young Stella Kleve from the 'grand old dame' of the romantic novel, Mathilda Malling, is by no means clear-cut. As Lingebrandt puts it: «stilistiskt hittar man visserligen inte längre 8o-talets impressionistiska fläktar och dekadenta utsvävningar, men tematiskt tar fortfarande unga kvinnors lidelser och längtan stor plats» (Ibidem; «stylistically one no longer finds the impressionist whiffs and the decadent lavishness of the I88os, though, thematically, young women's passions and desires are still central»).

At the heart of the following pages is the attempt to sharpen the grasp of Stella Kleve's «impressionist whiffs». The question of impressionist traits in Kleve's prose was brought up in the I980s by the Danish scholar Pil Dahlerup, in her essay Impressionismen - 'En Unatur, som dog findes $i$ Naturen' (Dahlerup I987), partly dealing with the author ${ }^{3}$. Recently, both Ney and Lingebrandt have picked up the gauntlet in their studies dedicated to Kleve. Following the impressionist doxa as outlined in Sven Møller Kristensen's Impressionismen i dansk prosa, Dahlerup concludes that her examination of Kleve's short story Vid Beau-Rivage (I886d; At Beau-Rivage) gives as a result that the text is «i alt overvejende grad impressionistisk, en af de tydligste i nordisk litteratur» (I987: I49; «preponderantly impressionist, one of the clearest examples in Scandinavian literature»). Dahlerup's succinct stylistic analysis mentions «hyppige sceneskift, betydningsfulde replikker, tilbagetrukket fortæller, lys- og farvemaleri, tankestreger og raffineret brug af metonymi» (1987: 146; «rapid changes of scenes, lines charged with meaning, the withdrawal of the narrator, light- and colour painting, dashes, and a refined use of metonomy»), as textual characteristics conforming to

2 Carlander's thesis is available online at http://www.ub.gu.se/kvinn/gena/search/details. html?id=2246. Accessed 7 February 2018.

3 It should, however, be mentioned that Karl-Erik Lundevall spoke of Stella Kleve's literary impressionism already in I953. Lundevall's perspective is of a different kind as it establishes, on the basis of a personal, unverified association, a cursory parallel to the visual arts when reading the description of a rye field in Kleve's second novel Alice Brandt as an impressionist painting, cf., Lundevall I953: III, 243. 
Kristensen's theory of literary impressionism. In her discussion of the short story's impressionism, Dahlerup also transfers René Huyghes' treatment of painterly impressionism to literature, and applies it to Kleve's use of a metaphorical language in which the energy of nature and of civilization clash (I987: I48); a stance («holdning») which, from Dahlerup's point of view, is the fundament of the impressionist style (1987: I49).

Birgitta Ney carries Dahlerup's observations on Vid Beau-Rivage further by adding observations regarding the technique of in medias res, as well as a few, somewhat shallow, references to the art of Berthe Morisot, and Claude Monet (I993a: I47)4 . The notion of literary impressionism is however functional to the overall discourse presented in Ney's doctoral dissertation because it is considered to widen the understanding of those specificities in Kleve's prose that so offended her contemporary readership: thus, Ney (I993a: I52, I54) sees impressionism as a mode by which Kleve could award prominence to the 'energy' and to the specific point of view («blicken») characteristic of her writing building on female experience. More than as a literary style, impressionism is here, too, seen as an attitude towards life, «ett uttryck för en hållning, en livsuppfattning» (I993: 152; «an expression of a stance, an ideology»). Next to Vid Beau-Rivage, another short story that suits Ney's interpretation of Kleve's impressionism is Pyrrhussegrar (I886c). This latter tale is also at the centre of Ney's article from 2005, which, in spite of its title, Impressionism och modernitet hos Stella Kleve (Ney 2005; Impressionism and Modernity in Stella Kleve), only very briefly refers to Kleve's modern form as impressionist, a definition which is here to be understood in terms of «nervousness» (2005: I06), and as prose with a clear message although dense with implicit allusions: «det antydda och underförstådda i Stella Kleves impressionistiska stil förhindrade inte heller att budskapet gick fram» (2005: 105; «the allusions and the unsaid in Stella Kleve's impressionist style did not prevent the message from being clear»)5.

Ann Lingebrandt adds her voice to this choir when stating, on the subject of Pyrrhussegrar, that «stilen är uppjagat impressionistisk, form och tema i perfekt samklang» (Lingebrandt 20II: 70; «the style is hectically impressionist, form and theme in perfect harmony»). Lingebrandt, however, also includes Stella Kleve's debut novel, Berta Funcke, within the groups of works characterized by the author's literary impressionism. Lingebrandt speaks of the novel's composition as a series of «ögonblicksbilder [...], likt ett pärlband

4 On other occasions, too, Ney similarly falls back on loose interart analogies. When referring, for example, to the short story Hendes Durchlauchtighed (Her Highness), Ney speaks cursorily of Kleve's description of an interior as «denna impressionistiska tavla» (I993a: I44; «this impressionst canvas») and «en impressionistisk skiss» (Ibidem; «an impressionist sketch»).

5 The same evaluation is given in Ney's entry on Kleve in Nordisk kvindelitteraturhistorie (Nordic Women's Literary History). The scandal aroused by Pyrrhussegrar is said to be dependent not only on the subject treated, female eroticism, but also on its form, «en nervøs, impressionistisk stil» (Ney I993b: 545; «a nervous, impressionist style»). 
av impressionistiska scener» (20II: 45; «instantaneous images [...], similar to a pearl string of impressionist scenes»), all concentrating on the protagonist's sensorial experiences. By contrast, Kleve's second novel Alice Brandt is, according to Lingebrandt, a text in which «de impressionistiska stildragen är nedtonade, istället är det mera teori och diskussioner» (20II: IOI; «the impressionist traits are toned down in favour of theoretical discussions»), while the numerous short stories are marginalized as «"småstycken" eller "stämningsbilder" [...] ofta rätt bagatellartade, med något stycke här och där som blänker till i hennes karaktäristiska impressionistiska stil» (2011: ıо6; «"bits and pieces" or "atmospheres" [...] mostly rather trivial, occasionally lit up by passages written in her characteristic impressionist style»).

In short, scholars such as Dahlerup and Ney have primarily been preoccupied with what they saw as an impressionist 'attitude' in Kleve's approach to her subject. To the extent that impressionist traits in Kleve's prose are delineated in their critical contributions, these are roughly explained with the help of Sven Møller Kristensen's studies in literary impressionism (I938 and I955), or cursory defined in terms of 'nervousness' or 'instantaneous images', 'hectic' states of mind, and an emphasis on the implicit. This state of affairs thus calls for a deeper investigation into the presumed 'impressionist whiffs' in Stella Kleve's writing. Therefore, I will subject to close scrutiny Kleve's debut novel Berta Funcke as well as the short stories published in the I880s, with the ambition to reveal the dimensions of her literary impressionism ${ }^{6}$. A reading of Kleve's strategies of description and prose style in terms of an impressionist narrative is all the more interesting as the writer herself, in I920, when looking back at the mid-I880s, precisely claimed to have been an impressionist writer in this decade.

This self-referential statement regarding the nature of her prose of the I88os, thus suggesting the appropriateness in discussing this writer's connection to literary impressionism, is a detail that has been overlooked in all the above mentioned studies concerned with the art of Stella Kleve, as well as in Torbjörn Nilsson's book on Bang's impressionism (Nilsson I965), which also briefly touches on the Danish writer's relationship to Kleve. Indeed, this avowal, present in the first part of her two autobiographical works, Uppfostran och inflytande: 1864-1885 (Malling I920; Education and Influence: 1864-1885) makes of the Swedish Mathilda Malling, next to Herman Bang, one of the few Scandinavian authors to have spoken of themselves as impressionist writers. Let us take a closer look at the circumstances regarding this self-definition.

In I920, while working on her autobiography, Malling goes back to the diary she kept in the I880 s to truthfully render the encounters with Bang in

6 Birgitta Ney has traced around thirty short stories published with the pseudonym Stella Kleve, or signed 'SK' or 'Bébé', in Danish, Finland-Swedish, and Swedish newspapers and periodicals, cf., Ney I993a: 263-64. 
Copenhagen in the winter of $\mathrm{I} 884$, and comments on the quality of her diary annotations from this period. Referring to her frequent discussions with Bang, Malling states that «as an impressionist», she was, at the time she wrote the diary, less interested in the content of their deep conversations than in the «graphic» rendering of Bang's statements:

Sedan komma vi under samtalets lopp in på religionen, det mänskliga lidandet, de oskäliga djurens lidande - ingenting originellt, men jag, som framför all [sic] är impressionist och objektiv skildrare, återger som vanligt grafiskt alla hans yttranden, rörd och djupt smickrad af alla dessa djupsinniga förtroenden. (Malling I920: 2I6-I7)

During our conversation we speak of religion, the sufferings of the human kind, the sufferings of innocent animals - nothing original, but I, who, above all, am an impressionist and an objective narrator, render, as usual, all his utterances graphically, touched and deeply flattered by all these profound confidences.

Of interest in the passage above is not only Malling's self-definition of being an impressionist: what is more, by equating the «impressionist» and the «objective narrator», Malling gives us a clue to her vision of the essence of the literary impressionist in terms evocative of Herman Bang's own ideal of a detached, unobtrusive narrator. The somewhat obscure idea of rendering the confidences of her conversation partner 'graphically' would perhaps have been possible to clarify had Malling's diaries been preserved. Unfortunately, they have all been lost or destroyed (Ney I993a: 34).

Given Stella Kleve's connections to Herman Bang, suggestions from the Danish author are, conceivably, of interest for the purposes of the present study. I will briefly look at possible ways to address this query before concentrating on the narrative dimensions of Kleve's impressionism.

\subsection{STELLA KLEVE AND HERMAN BANG}

The influence of Bang on Kleve's writing has been hinted at, but only on a superficial level (cf., Ney I993a: I45, I993b: 545, 2005: 29-30; Nilsson I965: I05). In an early evaluation of the artistic liaison between Kleve and Bang, David Sprengel regarded the former as broadly influenced by the prose of the latter and indicated Berta Funcke as «den första, ohöljt Bang imiterande lilla boken» (Sprengel I902: 373; «the first little book openly imitating Bang») 7 .

7 Writers emulating Herman Bang's scenic impressionism are, as expected, more eas- 
In Uppfostran och inflytande: $1864-1885$ from I920, Malling writes of one of her own early attempts to imitate Bang's style, found in the diary she consulted while working on her autobiography: «i synnerhet finnes en regnstämning - Wetteryd 2 oktober - i den beundrade Herman Bangs allra värsta manér, hvilket jag under flitiga studier av Haabløse Slagter och Tunge Melodier nu gjorde mitt bästa att till gagns tillägna mig» (Malling I920: 20304; «there is, in particular, a rainy day-mood - Wetteryd 2 oktober - in the very worst manner of the venerated Herman Bang, which I was now doing my best to make my own through intense studies of Haabløse Slogter and Tunge Melodier») ${ }^{8}$.

Birgitta Ney (I993a: 25-28) has carefully accounted for the circumstances in which Stella Kleve looked up Herman Bang in Copenhagen on her return from Switzerland in the month of August in I884, an episode individually documented by both writers. As editor-in-chief of Nationaltidende, Bang took the decision to publish Kleve's short story Et barn af vår tid (A Child of Our Age) in his own Danish translation and with the new title Flirtations. Moreover, he also signed the preface to Berta Funcke, Kleve's I885 novel building on the same short story9.

ily found among Danish literates than elsewhere on the Scandinavian literary scene. Agnes Henningsen (I868-1962) is an example of one of the authors whose style seems to have sprung from the Danish impressionist master. In Nordisk kvindelitteraturhistorie 3, Beth Juncker (I996: 84) speaks of her technique as a «scenisk-dramatisk impressionisme» originating in Herman Bang's method, although Henningsen, who had befriended the author and could count on his help with the publication of her first short stories in I89I, would come to put her own fingerprint on the mode by developing «den dramatiske impressionisme og den særlige spejlingsteknik, der skulle blive hendes fiktions kendetegn» (Juncker 1996: 85; «the scenic impressionism and the particular technique of mirroring, which were to become the hallmark of her fiction»), especially from the work Strømmen (The Current) published in I899, and onwards. For information on Agnes Henningsen see Zibrandtsen 2003 available at http://www.kvinfo. $\mathrm{dk} /$ side/I70/bio/425/. Accessed 23 January $20 \mathrm{I} 8$.

8 Birgitta Ney notes that on other occasions Kleve was upset by the critics' insistence on her dependence upon Bang's influence, cf., Ney I993a: 243-44, note 47. The adjective «worst», used in the quoted passage, seems indeed to suggest Malling's dissatisfaction, in 1920, with her earlier mannerism.

9 After the publication of her short story Flirtations, Kleve spent several months in Copenhagen enjoying the company of Bang and his books while working on her upcoming novel. On the subject of Berta Funcke, Lingebrandt (20II: 42) writes: «under vintern arbetar hon om och utvidgar sin novell, efter Bangs råd och de fingervisningar som hans översättning gett. Också hans person kliver in i romanen, lätt förklädd till Nils Max» («during the winter she restructured and expanded her short story according to Bang's advice and the suggestions offered by his translation. Even his person enters the novel, thinly disguised as Nils Max»). According to Lingebrandt, Bang's preface to the novel was, more than anything else, a drawback for the debuting novelist: «uppenbarligen kom också Herman Bangs entusiastiska presentation [...] att ligga henne till last: det talades om imitation, bangska egendomligheter drivna till parodi, efterbildning ledd av dålig smak, Fæedra-atmosfär "här blott simplare och än mera tillgjord"» (20II: 57; «quite evidently Herman Bang's enthusiastic introduction [...] proved a stumbling block to her: there were voices arguing for imitation, specificities of Bang's prose driven to parody, mimicry on a ground of bad taste, Fredra-mood, "though in this case simpler and more conceited"»). 
Looking back on these years in I920, Malling herself speaks of Bang's preface as an occasion in which the Danish master lifted her up to his level, though perhaps at the wrong moment: «att Bang, som då stod på höjden af sin impopularitet, skref ett långt förord till boken, hvari han på sätt och vis uppställde mig [...] som ett slags kvinnlig pendant till honom själf och de mest avancerade modernisterna i Norden, har jag ofta hört tadlas» (Malling I920: 222; «that Bang, who at the time was on top of his unpopularity, wrote a long preface to the book in which he, in one way or the other, presented me [...] as some sort of female pendant to himself and to the most advanced modernists in the Nordic countries, is something that I have often heard being criticized»). Kleve, on the other hand, in an article entitled Om efterklangs- och indignationslitteraturen (Kleve I886b; On the Literature of Indignation and Reverberation), presented Bang to the Swedish readers as a modern writer who deserved their attention. According to Torbjörn Nilsson, the influence was indeed two-sided. Nilsson (1965: I68) mentions Kleve's short story Hendes Durchlauchtighed (also published in Danish in the journal Nutiden in December 1885) as a source of inspiration for Bang's tale Hendes Højhed. Correspondences regard, in Nilsson's opinion, however only the content: while Bang's tale is written in his characteristic impressionist style, Kleve's short story rather mimics the earlier Bang, the author of Fadra (Nilsson i965: 168-69).

At the end of her I920 autobiography, Malling (I920: 2I4-3I) dedicates a long passage to the friendship that developed between her and Herman Bang during her sojourn in Copenhagen in the winter of I884. The following lines are exemplar of the tone characterizing Malling's retrospective view of her admiration for the Danish author and early attempts to write in his manner:

Som skribent beundrade jag honom utan förbehåll och finner alltjämt att han - sådan som han är - med sina svagheter och sina företjänster - är en af de mest fängslande, egendomligaste och mest öfvertygande skönlitterära skildrare, Skandinavien någonsin har frambragt. Som jag redan har anmärkt, visste han det också mycket väl själf och gjorde ingen hemlighet af det. En gång - på tal om Excentriske Noveller - sade han till mig: "Lad kun Bladene skælde mig ud! Danmarks Litteraturhistorie vil engang være god mod mig”. Men naturligtvis kan ingen annan tillägna sig hans egendomligheter, och mitt fel var, att jag i min stora grönhet försökte mig på det. Mina första tryckta arbeten har jag inte på många år läst igenom, men när jag nu sitter och tittar i dagboksanteckningarna från samma tid, riktigt grufvar jag mig öfver min affekterade stil. (I920: 220-2I)

As a writer I admired him immensely and I still find that he the way he is - with all his weaknesses and assets - is one of the 
most haunting, peculiar and convincing writers of fiction of all times in Scandinavia. As I have already mentioned, he was very much aware of it himself and made no secret of it. Once - on the subject of Excentriske Noveller - he said to me: "Who cares if the newspapers attack me! Danish literary history will eventually be good to me". But of course no one can make his peculiarities their own and my fault, inexperienced as I was, is to have made an attempt at it. I have not read through my first published works in years, but as I now look through my diary from those days, the pretentiousness of my style really does bother me.

As Birgitta Ney has observed (I993a: 29-30), the artistic dialogue between Herman Bang and Stella Kleve would have been more easily clarified had it been possible to establish an approximate date of composition for the short stories published in the I88os; although Mathilda Malling burned the original manuscripts there are specificities in these tales that seem to indicate that they were written before the encounter with Bang in I884. During the work on her memories, Malling observes that when going through the diary entries annotated in Switzerland in the summer of I884, she already encountered early drafts to her short stories: «här spirar alltså grodden till de typiska “Stella Kleve” novellerna, som [...] gång på gång söka bryta sig fram i den lilla tunna dagboken och gång på gång undertryckas af mera handgripliga uppgifter» (I920: I66; «So this is where the typical "Stella Kleve"-short stories germinate, [...] insistently trying to make their way through the tiny little diary, insistently submerged by more concrete facts»). She also admits, however, that Berta Funcke was written bearing in mind Herman Bang's Danish translation of the short story that had formed its basis. The tale was reworked into a novel according to «de vinkar den danska öfversättningen, som kastat ett något annat skimmer öfver den ursprungliga skizzen, gaf mig» (I920: 22I; «the suggestions that the Danish translation, which had thrown a slightly different lustre on the original sketch, had given me»).

When Malling reveals (I920: 224-25) that she asked Bang to buy her a copy of the very novel that Ferdinand Brunetière had used as an example to illustrate the phenomenon of literary impressionism - Alphonse Daudet's Les Rois en exil - we seem to have come full circle. It is therefore high time to move on to the study of Stella Kleve's own impressionist whiffs.

\subsection{THE DIMENSIONS OF STELLA KLEVE'S IMPRESSIONISM}

The point at issue here will be to lay bare those specificities of Stella Kleve's narrative strategies that relate to impressionist modes of writing as mapped by authors and critics who have made attempts to theorize the craft of im- 
pressionist writers, and identify their function in the texts. I will attempt to explain the most clearly marked impressionist traits in Kleve's prose with the help of aspects central to Herman Bang's, Sven Møller Kristensen's, Ian Watt's, and Ford Madox Ford's theorizations. As I see it, the dimensions of Stella Kleve's impressionism encapsulate traits of scenic impressionism, the metonymic mode, and the idea of 'delayed decoding', a term coined by Ian Watt in his interpretation of Joseph Conrad's impressionism, but of which Sven Møller Kristensen (I955: II9-34) spoke, with reference to J.P. Jacobsen, as a facet of the 'phenomenological apperception' characterizing the transmission of impressions in literary impressionism. Kleve also makes a singular use of punctuation marks, the function of which will be related to her impressionist style and discussed in conclusion.

\subsubsection{Scenic impressionism}

As we have seen in the foregoing analysis of Herman Bang's impressionism, the Danish novelist was primarily concerned with pursuing a dramatic method in prose writing. This solution to the problem of interpreting literary impressionism is not only limited to showing rather than telling, but is, according to Sven Møller Kristensen (I955: 34), often also visible in the impressionist writers’ «indledende regiebemærkninger» («initial set directions»), which support the construction of a scenic narration. As Kristensen puts it, these stage directions are «især brugt ved indledningen til en situation, som en regulær scenebeskrivelse, der oftest foregår i knappe og korte nominalsætninger, en objektiv form, der giver ringe indtryk af fortællerens tilstedeværelse» (Ibidem; «especially adopted to introduce a situation, and as a regular set description, which often makes use of spare and short nominal phrases, an objective mode giving little evidence of the narrator's presence»). This manner of initiating a story found its way into Stella Kleve's prose and its effects are particularly striking in the opening paragraphs to short stories such as Flirtations (1884a), Ensam (1886-87; Alone), and Vinterstycke (I884C; A Winter Fragment), as well as in the novel Berta Funcke, all examples of how the author, when setting the stage, resorts to nominal sentences or to the use of verbs in the present tense. To illustrate the technique with just one significant example, we will take a look at the opening lines to Flirtations, which sound as follows in Bang's Danish translation ${ }^{\mathrm{IO}}$ :

Et stort Værelse med to høje Vinduer ud mod Humlegaarden; rige, dobbelte Gardiner. Tykke, blomstrede Tæpper, i hvilke Foden sinker; Bord belastedt med Pragtværker, Modejournaler

Io In the novel Berta Funcke published the following year, this passage is replicated almost identically, though in Swedish, cf., Kleve I885: 36. 
og Aviser. I det ene Hjørne et lille Skrivebord med en Buste af Goethe, mellem Vinduerne et aabent Pianoforte. Bogskab, Chiffonière, en lille Seng med et Silketæppe, halvt skjult af alle de Musselindrapperier - hist og her Blomster i Holdere og smaa Statuetter. (I884a, 25 September)

An immense room with two high windows looking out on Humlegården, heavy, double curtains. Thick, floral-patterned rugs, into which the foot sinks, a table loaded with coffee-table books, fashion magazines, and newspapers. In one angle a small desk with a Goethe bust, between the windows an opened piano. Bookshelves, a chiffonnier, a little bed with a silk spread, half-hidden behind a wealth of muslin draperies - here and there flowers in vases and small statues.

In Kleve's production we also find examples of tales - such as Vid BeauRivage (I886d), Morgondrömmar (I888b; Morning Dreams), Hemkomst (I886a; Homecoming), and På bröllopsresa (1884b; On Honeymoon), or sections in Berta Funcke - in which the action starts unrolling in medias res, with lines or actions that belong to unintroduced characters, apparently unfamiliar to narrator and reader alike but true to the scenic character of the narration.

Essentials in «den iscenesatte fortælling» (Møller Kristensen I955: 34; «the staged narration»), as pursued by Stella Kleve, are thus the submerged narrator, the presence of set directions, and, as we will see, the use of direct speech in which the lines are coloured by the specificities of expression peculiar to each character, sometimes driven to the point of becoming what Møller Kristensen terms «replikmosaik» (I55: 3I; «a mosaic of lines»), explained as «et yndet motiv for impressionisten [...] indtrykket af mange personers samtidige tale, fx. i selskaber. Replikerne kommer i flæng, flimrende og kaotisk, så i regel kun tonefaldet røber personerne. Bang er mester i denne form, som man især træffer ofte i Stuk» (Ibidem; «a favourite motif among the impressionists [...] the illusion of simultaneous conversations engaging many persons, e.g., at social gatherings. Verbal exchanges are indiscriminate, vibrating, and chaotic, and, as a rule, the characters are given away only by the tone of their voice. Bang is the master of this form, which is frequently observed in Stuk»).

In a novel like Berta Funcke, whose protagonist has an undying love for the theatre and a personal talent for acting, the adoption of scenic impressionism is particularly pertinent. When Stella Kleve here pictures a scene set at a train station, the effort to customize the characters' individual lines is evident all the way down to the author's use of typography to indicate pauses, coarseness, perhaps hesitation, while the impression of a frenzy, 
multilingual crowd is made visible through occasional uses of the present tense, direct, unattributed speech in different languages, insubstantial diegesis and, again, through typographical choices:

\author{
“Seså, Berta, der ha vi tåget." Berta samlar ihop sina saker i hast: \\ "Pappas paraply - der." \\ Dörrarna slås upp: \\ "Lausanne - Neuchâtel - Bâle." \\ Rök och drag på perrongen. Ett oupphörligt knuffande: "Pardon, \\ mais mille pardons! -" \\ "Non-fumeurs - Berta, här!" \\ [...] Han tryckte handen och såg henne in i ögonen - mörka, \\ glänsande, under det svarta floret. \\ - - \\ Så började tåget att gå. \\ Han såg henne ännu stå qvar på platformen - hög och slank, \\ med sänkt hufvud - båda händerna mot den blanka jernstången. \\ Och han hviskade sakta ännu en gång: \\ “Farväl!” (Kleve ı885a: г38)
}

"Well, then, Berta, here comes the train." Berta gathers her belongings hastily: "Father's umbrella - there."

Doors open.

"Lausanne - Neuchâtel - Bâle."

Smoke and gusts by the track. A constant jostling: "Pardon, mais mille pardons! -"

"Non-fumeurs - Berta, here!"

[...] He squeezed her hand and looked her in the eyes - dark, glowing, behind the black veil.

Then the train departed.

He watched her lingering at the platform - tall and lean, head hanging - both hands on the lucid iron railing. And he whispered slowly once more:

"Farewell!"

However, as Møller Kristensen observes, to realize the ideal of the scenic novel by recurring, in this way, to «nøgne repliker» (I955: 32; «naked lines») is not enough: characters have to be exposed to the reader also through their movements, mimicry, and gestures. To Bang, as we have seen, the impressionist writers should make no attempt at analyzing the characters from 
within by allowing themselves access to the thoughts and feelings of their literary creatures, but should merely focus on those actions and externally observable movements revealing thoughts and feelings. In Bang's words: «hver lille Handling er et Glughul ind i det skildrede Menneskes Tankeliv» (I890a: 693; «every little action is a peephole into the thoughts of the character described»).

It is my conviction that the gravitation towards the narrative modes of scenic impressionism in Stella Kleve's prose is practised with the precise purpose of heightening the reader's awareness of the text's thematic concentration on women in the role of seducers and female eroticism that, due to the social conventions of the age, were not allowed to emerge - not even in fiction. Ann Lingebrandt moves in the same circles when, on the subject of the importance of the multiple points of views and the exchange of looks between the characters in Kleve's prose, she writes: «skiftena i fokus och spelet mellan olika slags blickar förstärker också ledmotivet om sken, förställning och dolda sanningar: det vi ser på ytan och det vi anar därunder» (20II: 52; «the changes in focus and the play with different kinds of gazes reinforce the leitmotif of illusions, daydreams, and hidden truths: what is observed from the outside and what is perceived underneath the surface»). The following passage from Berta Funcke is of interest to the issue investigation as it reveals how the protagonist herself, with an initial understatement, reflects on the significance of these exchanged looks. Meanwhile, through the concluding diegetic comment and in line with the principles of scenic impressionism, the narrator declines to probe the improbable (the character's thoughts and feelings) and instead fixes the gaze on the physical reactions of this femme fatale: the tremor, the escalating pallor, and the intensified shadows underneath Berta's eyes, all details indicative of this woman's innermost feelings:

- - - "Åh - det är knapt värdt att tala om - - Men ibland kan jag från hörnet af en jernvägskupé, från en loge på theatern vexla en blick med en obekant - en, som jag aldrig har sett förut. Och under lokomotivets buller eller musiken från orkestern sjunker blicken djupare - blir 'fastare', mera bestämd - - - men jag känner aldrig någon lust att få veta hvad han heter eller odla en sådan bekantskap. Möter jag honom nästa dag - kanske en blick, ett leende - sedan är det förbi."

Hon lät fingrarne dröjande glida öfver solfjäderns röda sidenkant. De tego båda. Så sade han sakta: "Mins ni, hvad Sti Högh sade om ‘de Melankolske store Samfund?' - Ni tillhör det.”

Hon darrade lätt och svarade icke. Men hon blef blekare - vidunderligt blek - och ringarne under hennes ögon syntes nästan svarta. - - - - - - - - - (I885a: II4) 
- - - "Oh - it is hardly worth mentioning - - But sometimes from the angle of a train compartment, from the box seat at a theatre, I happen to exchange a look with a stranger - one whom I have never seen before. And in the midst of the noise of the engine or the music from the orchestra, the look deepens - grows 'sharper', and more determined - - - though I never wish to find out his name or engage in a friendship. Should I run into him the following day - perhaps a look, a smile - then it is over."

She let her fingers trail over the red silk border of the fan. They were both quiet. Then he said: "Do you remember what Sti Høgh said of 'the great fellowship of the melancholics' - You belong there."

She shivered lightly and did not answer. But she grew paler - mysteriously pale - and the circles underneath her eyes appeared almost black. -----------

In the following quotation from Kleve's debut novel, the author very clearly combines narrative concentration on mimicry and overwrought physical movements with allusions to the veiled eroticism that is seething beneath the transparent shell of the male character's body language when striving to maintain control over a rampant horse, at least in the eyes of the onlooker Berta Funcke:

Så såg hon honom en gång - på en ridtur de gjorde tillsammans på Djurgården - tygla en rasande häst. Hästen kastade sig tillbaka och stegrade sig gång på gång. Hon såg ryttaren böja sig fram i sadeln - läpparne hårdt sammantryckta, ådrorna på pannan svälde. - Med jernhand stramade han tyglarne, så att djurets hufvud böjdes hårdt mot bringan, och från den lyftade handen hven ridspöet ned.

Då hästen ändtligen gick spak och stilla, var Berta Funcke blek som döden. Löjtnanten, som red bredvid henne, trodde att det var af rädsla. -

Två dagar derefter friade excellensen och fick ja. (I885a: I42)

Then, as it happened, she saw him - during a ride they took together at Djurgården - reining in a restive horse. The horse backed up and reared repeatedly. She watched the rider lean forward in the saddle - lips tightly sealed, veins swelling on the forehead. - His iron hand tightened the reins, pressing the head of the animal hard against its breast, and from the lifted hand the riding whip flicked. 
When the horse became calm and docile again, Berta Funcke was death pale. The lieutenant riding beside her thought it was out of fear.

Two days later His Excellency proposed and his proposal was accepted.

On the subject of the text's subtle sensuality, which is never explicit but always contained in tangible minutiae, Ann Lingebrandt writes:

Mer fysiskt än några upphetsade andetag och ett par kyssar blir det aldrig. Istället får de konkreta detaljerna härbärgera alla de stämningar av lust och lidelse som sjuder under ytan. Kusinens svettiga mössa. Ett litet ärr vid munnen hos en av beundrarna som Berta inte kan låta bli att vidröra med sitt lillfinger. Sättet hennes danskavaljer håller huvudet och hur hans hår doftar. (20II: 47)

It never gets more physical than a few aroused gasps and a couple of kisses. Concrete details are instead made to accommodate all the feelings of lust and passion that simmer underneath the surface. The cousin's sweaty cap. A small scar next to the mouth of one of her admirers that Berta cannot refrain from touching with her little finger. The manner in which her dance partner is holding his head and the smell of his hair.

Lingebrandt's reading of Kleve's attention to fragments and particulars of surface phenomena indicated the path to my own understanding of the author's narrative strategy, to the conviction, that is, that her particular descriptive technique is indebted to impressionist representation. This connection is, as has been foreshadowed in the above, supported by one of Kleve's own statements regarding her practice of description (which will be commented on in the following section), according to which her focus in the I880 production was on the abundance of details. I see this trait as illustrative of her impressionist vein and ground my view on Møller Kristensen's theory of the impressionist narrative in which special prominence is awarded to «de mange metonymiske figurer» (I955: I23; »the many metonymic modes»), emblematic of literary impressionism in general and, in particular, of impressionist character description: «de optræder især i forbindelse med fremstillingen af personer; impressionisten ser ikke det hele menneske, men opfatter i det flygtige øjeblik oftest kun en del af det» (Ibidem; «these appear especially in connection with the representation of characters; the impressionist does not see the entire person, but often grasps only a part of 
him or her in the fleeting moment»).

In short, in the following attempt to shed light on Kleve's use of fragments and trivia, I will depart from the author's self-definition and from Møller Kristensen's theorization to develop a discourse on the metonymic mode as an aspect of her prose impressionism. As Møller Kristensen puts it, «metonymien får i den impressionistiske stil en ny variant, hvor den mest fremtrædende sansekvalitet hos en ting bliver ersatning for tingen selv» (Kristensen I955: II9; «a new version of metonymy, in which the dominant sensorial quality of an object replaces the object itself, is present in the impressionist style»).

\subsubsection{The mirror crack'd. On the metonymic mode}

As stated by Mathilda Malling herself in the autobiographical work Uppfostran och inflytande: 1864-1885, the composition of her debut novel, Berta Funcke, came to a large extent to depend on the new «litterära fordringar» (I920: I67; «literary requirements») that she had gained insight into after Bang's intervention on the short story Et barn af vår tid, which had become Flirtations in his Danish translation. These new-found 'literary requirements' are subsequently explained in terms reminiscent of a narrative strategy that I will term 'the metonymic mode', in a wish to follow up on Sven Møller Kristensen's reflexion on the metonymy as a figure of speech central to impressionist prose.

On the subject of character descriptions in her prose dating back to the mid-eighties, Malling writes: «det vimlar af "nackar”, "ryggar”, “ögon” och "leenden” - ryttare på den då brukliga höga cykeln som jag ännu tycker vara vådligt pittoresk» (Malling I920: I67; «there is a multitude of "necks", "backs", "eyes", and "smiles" - riders on the high wheeler which was popular at the time and which still seems terribly picturesque to me»). As we have seen in the preceding chapter, the response, both literary and painterly, of the impressionists to the inventories typical of naturalist description lied in an attempt to employ single, essential, details in the representation of a totality. In Cuddon's handbook definition (I991: 446), for instance, impressionism is said to be a writing concerned with selecting «a few details to convey the immediate sense impression left by a scene», and Willy Dahl explains impressionist description as follows: «ikke alt skulle med i bildet, bare det vesentlige, det som trakk blikket til seg, det første inntrykk» (Dahl I98I: 70; «not everything would come into the picture, only what was essential, what attracted the vision, the first impression»).

As I see it, Kleve's basic narrative solution to the problem of description - the multitude of fragmentary minutiae ever-present in her work from the I880 - can be said to reside in the metaphor of the cracked mirror which 
appears in the short story Pyrrhussegrar as a sort of mise en abyme; a looking glass which can no longer reflect an entirety, but splits it into single details representing the whole:

$\mathrm{Nu}$ såg hon hela sitt liv som i en krossad spegel, vilken ej är i stånd att helt och hållet återgiva bilden av ett föremål, men som i varje skärva speglar en stympad torso. För hennes minne dök där oupphörligt upp - än ett ansikte, än en figur i en viss ställning, - en roddares nakna arm, en solbränd nacke under en styf, upprättstående militärkrage, en upplyft fot med skridsko. - Och kring sådana motiv växte där småningom fram en hel situation - skarp, tydlig och färgrik - tills den gled över i en annan och vek för den. (I886c, italics in the original)

She now saw her whole life as in a cracked mirror, which no longer can reflect the complete image of one object, but whose every shard reflects a severed torso. Appearing unremittingly to her mind - once a face, once a body in a certain pose, - the naked arm of a rowing man, a sunburnt neck behind a stiff, upright military collar, a raised foot wearing a skate. - And around these motifs a whole situation eventually came forth - sharp, distinct and colourful - until it gave way to another and disappeared.

Commenting on J.P. Jacobsen's technique when describing the appearance of a girl in the woods in the short story Mogens by concentrating on a face and a slender hand while omitting to identify the owner of the face and of the slender hand, Møller Kristensen explains Jacobsen's use of metonymy as follows: «der gøres her ingen bemærkninger om, at der er en pige, der er indehaver af det lille pigeansigt og den lille hand. De er kun isolerede detailer i et helt synsindtryk» (I955: I20, italics in the original; «no comments to indicate that there is a girl who is the owner of the little girlish face and the little hand are made. These are but isolated details in the totality of the visual impression»). Likening this particular aspect of his greater category of 'phenomenological apperception' to metonymy, he continues, with numerous examples from Bang, Pontoppidan, Drachmann, Stuckenberg, and others, to explicate this idea and its relevance to impressionism:

Med den fænomenologiske opfattelse følger en gennemgaaende tendens til ikke at reproducere en genstand fuldstændigt. Man ser ikke genstanden som en helhed, en sum af egenskaber, men kun en enkelt af dem, den iøjnefaldende, som derfor reproduceres alene, isoleret, uden at blive forbundet med sin bærer. Derfra kommer de mange metonymiske figurer i den impressionistiske 
stil. De optræder især i forbindelse med fremstillingen af personer; impressionisten ser ikke det hele menneske, men opfatter i det flygtige øjeblik oftest kun en del af det. (Møller Kristensen I955: I23)

With phenomenological apperception comes an overall tendency not to reproduce an element completely. The element is not seen as a totality, a sum of characteristics, but a single detail that strikes the eye is reproduced alone, without any connection to its bearer. This is the origin of many a metonymic figure in the impressionist style. These appear especially when people are represented; the impressionist does not catch the whole person, but most often gathers only a fragment in the fleeting moment.

I find it significant that even «bicycleryttaren», a rather frequently recurring secondary character in Kleve's prose and one that Malling, as we have seen, declared to find «terribly picturesque», should undergo this treatment. When he rides past in the short story Pyrrhussegrar, Kleve does not revel in his appearance; instead of giving prominence to the vision, she favours reporting the manner in which the observer experiences this vision. The bicycle rider is thus dismantled to the reproduction of a bent leg, a curved back, a cap, and the glittering spokes of the wheel: «ett trikåklätt ben krökt mot hjulets glittrande stålskenor, en kraftig, litet framåtböjd öfverkropp och ett hufvud med flat skotsk mössa. - - (I886c; «a leg in tights, bent against the glittering steel spokes of the wheel, a sturdy, slightly curved torso, and a head with a flat cap. - -»). Rather than a portrait, he becomes «a document on the fragmentary state of the vision of a certain moment», to borrow Victor Carrabino's words on impressionist perception (1984: 263).

Examples of descriptions building on acts of perception that convey only a few noteworthy features emblematic of the scene observed are especially frequent in Kleve's prose when it comes to character description. Many of her stories share the setting of ballrooms or dinner parties in private houses where countless characters appear and disappear in the crowd. A distinctive feature in these descriptions is Kleve's tendency to overlook panoramic views of the gatherings and instead focus on single body parts and details in clothing or interior design - or on the combination of the three. In the following two examples, which can be considered as typical accounts of society life in Kleve's prose, the writer renders the conversations between guests by directing the reader's interest to the minute detail of a woman's rosy ear, which appears behind the silky fabric of her evening gown or, as in the second example, records female flirtation by focussing on a gloved hand and flickering eyes: 
Herrarne hade dragit sig in i rökrummet - endast några få af dem hade stannat qvar i salongen. Der stodo de nu och hängde öfver damernas stolar - böjde sig ibland ned och hviskade någonting i ett litet rosigt öra öfver silkesfräset-- - (I885a: I05)

The men had withdrawn into the smoking room - only a few of them still lingered in the sitting room. There they stood leaning over the ladies' chairs - occasionally bending over to whisper something in a little rosy ear behind a silky fabric - - -

Similarly, in the short story Förlofning (1885b; Engagement):

Här och der kunde man få se dem ligga på en grossörs divanbord för att efter middagen öppnas av en handskbeklädd hand, under det ögonen för hvart femte ord kikade upp derifrån till en annan herre, som icke 'kunde se hur erbarmligt tråkigt' ögonens egarinna hade. (1885b, 25 February)

Here and there one could see them lying on a merchant's coffee table to be opened after dinner by a gloved hand while the eyes looked up every five words to fix another man who had 'failed to notice what a miserably boring time' the owner of these eyes was having.

Metonymic in structure are many descriptive passages from the novel Berta Funcke in which Kleve also avoids connecting the isolated element to its possessor. In the following quotation in which dancers at a party are observed, the elements necessary to capture the festive atmosphere are fans, blushing faces, twinkling eyes, and women's shoes, all detached from their human framework: «Solfädrarne gingo hastigt fram och tillbaka förbi blossande ansigten och strålande ögon; skära och hvita atlasskor slogo tåspetsarne upp och ned mot golfvet i takt med musiken» (I885a: 89; «The fans flickered hastily to and fro in front of blushing faces and starry eyes; pink and white satin shoes hit their tiptoes up and down against the floor to the rhythm of the music»). On other occasions, the concentration on items of clothing is driven to a point where the metonymy is further refined, as in the following lines from Berta Funcke where the woman's outfit and the man's dust coat come to substitute the two characters of whom they are attributes:

I halfdunklet under de låga platanerna röra sig de promenerande fram och åter i en mörk, långsam ström. Af och till dyker der upp ur massan en ljus damtoilett, en engelsmans hvita damrock eller fladdrar den långa silkesslöjan kring hans hatt. På den låga stenparapeten längs med sjön sitta en hel del unga arbetskarlar 
och gossar. Stråhattarna på nacken, de blå bomullsblusarne pösigt uppdragna, dinglande med de klumpiga fötterna - (I885a: I23-24)

In the semi-darkness underneath the low plane trees the walking crowd moves back and forth in a slow, dark stream. Once in a while a woman's fair dress, an Englishman's white frock surface in the mass, or the long silk veil flutters around his hat. On the low stonewall along the lake sit quite a few young workers and boys. Straw hats on their necks, the blue cotton shirts bulging at their waists, dangling with their lumbering feet -

Kleve's focus on fragments centres, however, specifically on body parts. On these occasions the metonymic mode performs the function of accentuating the theme of sensual love which, although merely alluded to, so upset her contemporary critics and readers (see e.g., Ney I993a: 40-45). Though the point of view is clearly feminine, and thematic concentration is on female lust and passion, it is interesting that the description should pay attention both to the male body, as in the first example, as well as to the female physique, as in the second, thus blurring the boundaries between object and objectifier:

- - - Detta svarta, mattglänsande hår - så tjockt - om hon blott finge röra vid det. Kinden, som nästan snuddade vid hennes axel, - han borde verkligen icke sitta så sjelfsvåldigt - - - En sådan växt - - så fin och slank - Och skuldran, som sköt upp en smula - - (1885a: Io6, italics in the original)

- - - This black, opaquely shimmering hair - so full - if she only could touch it. The cheek that almost touched her shoulder, - he really should not assume such a self-conscious pose - - - What a physique - - so lovely and slender - and the shoulder, slightly raised - - -

And:

Inne i salongen var det halfmörkt - en enda stor lampa med skärm stod på ett konsolbord bredvid flygeln, så att nästan allt dess ljus föll öfver den spelande damen. Öfver hennes grönblå atlasklädning, hvars åtsittande lif glänste som ett harnesk öfver bröstet - hennes rena profil, mörka, högt uppsatta hår och hvita nacke, då hon böjde sig fram öfver instrumentet. Öfver hennes fasta, välformade armar - bara ända upp till axeln - och öfver fingrarne, som snabt flögo fram på tangenterna. -- (I885a: I04) 
Inside the sitting room it was semi-dark - one single big lamp with a screen stood on the console table next to the piano, so that almost all its light fell on the playing lady. Over her bluegreen satin dress, the waist of which glimmered like a cuirass over her breast - her clean profile, dark hair gathered on top of her head and white neck, as she leaned over the instrument. Over her full, well-shaped arms - but no further than to the shoulder - and over her fingers that rapidly flew over the keys. --

My last example, taken from Kleve's second novel Alice Brandt, combines the metonymic mode with a form of postponed processing of the scene described, which is interesting within our issue investigation. When Berta Funcke reappears in Kleve's second larger prose work, the narrator typically introduces her by concentrating on details in the woman's appearance (pallor, slimness, hair colour, nostrils), but creates an effect of de-familiarization by deferring the revelation of this lady's identity:

- Är det inte något med patchouli, du har der borta? - Det var en blek, slank cendré, som nu böjde sig fram ur gungstolen och med vidgade näsborrar begärligt insöp den svaga parfymlukten. - Åh du, låna mig den. - Vill du? - - (I888a: 33-34)

- Isn't it something containing patchouli you have there? - A pale, slender, ash-blonde now leaned forward from the rocking chair, avidly widening her nostrils to absorb the faint perfume. - Oh, lend it to me, - will you? - -

This narrative strategy which strives to grasp the dominating and immediately perceptible characteristic of the object of description while postponing the full understanding of the scene described, fits in with a canonical impressionist technique, namely the one defined as 'delayed decoding' by Ian Watt for the first time in a speech on Joseph Conrad delivered in I972, although Watt had important precedents in scholars such as Ford Madox Ford and Sven Møller Kristensen, who had described the same proceedings, though with different a terminology, years earlier.

\subsubsection{Delayed decoding. On arrows, bats, rain, and cigarettes}

'Delayed decoding' is a fortunate coinage created by Ian Watt and applied to designate a descriptive practice at work in Joseph Conrad's prose fiction. The expression, defined by Watt (I975) as an «impressionist narrative device», was first used with reference to a specific aspect of Conrad's narra- 
tive technique in Lord Jim, and subsequently further developed in the study Conrad in the Nineteenth Century, published in $1980^{\mathrm{II}}$. With his coinage, Watt wished to give attention to what he saw as an innovation in Conrad's narrative technique, explained in terms of an effort «to present a sense impression and to withhold naming it or explaining its meaning until later; as readers we witness every step by which the gap between the individual perception and its cause is belatedly closed within the consciousness of the protagonist» (I980: I75). Among the many meaningful examples drawn from Conrad's authorship to illustrate this device, Watt focusses on a central episode of Heart of Darkness in which the visual impression precedes the intellectual understanding of the scene: in the highly dramatic moment when his boat is attacked by bowmen, Marlow perceives the arrows that surprise him as sticks, and only later gains insight into the true nature of these sticks ${ }^{\mathrm{I2}}$. Watt (I980: I75) explains: «this narrative device may be termed delayed decoding, since it combines the forward temporal progression of the mind, as it receives messages from the outside world, with the much slower reflexive process of making out their meaning».

Of interest to my analysis here is, needless to say, the connection established between Watt's delayed decoding and impressionism. Watt (I980: I76) supports his definition of delayed decoding as an «impressionist narrative device» with a reference to interart parallelism: the method is understood as a textual strategy attempting to transfer to words the painterly representation which was the result of the untainted impressionist eye's look on reality. As Watt explains it, what Conrad developed is a

narrative technique which was the verbal equivalent of the impressionist painter's attempt to render visual sensation directly, Conrad presented the protagonist's immediate sensations, and thus made the reader aware of the gap between impression and understanding; the delay in bridging the gap enacts the disjunction between the event and the observer's trailing understanding of it. (Watt I980: 176-77) ${ }^{\text {13 }}$

II Cf., Delayed decodingathttp://www.oxfordreference.com/view/10.Io93/acref/9780I9860 42II.00I.000I/acref-97801986042II-e-0I02. Accessed 7 February 2018.

I2 Cf., Watt I980: I77; «"Sticks, little sticks, were flying about - thick: they were whizzing before my nose, dropping below me, striking behind me against my pilot-house." But it is only when Marlow has finished attending to his duty as captain, and negotiated the next snag, that his understanding can finally decode the little sticks: "We cleared the snag clumsily. Arrows, by Jove! We were being shot at!"».

I3 It is symptomatic of the state of the art in studies on literary impressionism that more recent critics should wish to avoid discussing this narrative feature as an outgrowth of impressionist painterly techniques. Distinguishing between «primitive» and «civilized» perception, H. John Peters (200I: 37) writes: «primitive perception represents an initial sense impression before the observer organizes it into a meaning that accords with past experience, while civilized perception represents the impression after the observer organizes the initial experience and ascribes meaning to it». Peters resolves (200I: I4): «contrary to most commentary, I would 
Years earlier, however, both Ford Madox Ford and Sven Møller Kristensen in their discussions of impressionist narratives identified technical features peculiar to literary impressionism that are perfectly aligned to Watt's idea of delayed decoding. Ford Madox Ford observed that in impressionist prose, the representation of a visual phenomenon should render what the onlooker actually experiences in the very instance he fixes his eyes on the scene, without attempting to set this sight in order according to a fashion depending on convention or on previous experience. Citing the example of Alfred Tennyson's detailed description of bats at dusk «with ermine capes / And woolly breasts and beady eyes» (Hueffer I9I4a: I72), Ford explains that it

is no doubt very good natural history, but it is certainly not Impressionism, since no one watching a bat at dusk could see the ermine, the wool or the beadiness of the eyes [...] to import into the record of the observations of a moment the observations of a moment altogether different is not Impressionism. (Ibidem)

Thus, he makes the conclusion that

it has, this school, [...] certain quite strong canons, certain quite rigid unities that must be observed. The point is that any piece of Impressionism, whether it be prose, or verse, or painting, or sculpture, is the record of the impression of the moment [...] it is the impression, not the corrected chronicle. (I9I4a: I73)

With reference to J.P. Jacobsen's prose, Møller Kristensen commented on the same narrative device but included it in a wider phenomenon characteristic of literary impressionism, which he termed «fænomenologisk apperception» (I955: II9-34; «phenomenological apperception»). With a quotation from the incipit of Jacobsen's short story Mogens depicting an initial rainfall, Kristensen points out how Jacobsen, through this impressionist mode of description, manages to remain true to the mechanism of the perceiving consciousness (that of the protagonist Mogens) by focussing first on the effect and then on the cause ${ }^{\mathrm{I} 4}$.

argue that any similarities between impressionist art and literature result from similarities in philosophy - not technique».

I4 Cf., «Den impressionistiske beskrivelse er typisk derved, at den begynder med virkningen, resultatet af en "kraft", og først derefter - eller overhodet slet ikke - når til erkendelse af kraften selv: "Pludselig kom der en lille rund, mørk Plet paa det lysegraa Muld, een til, tre, fire, mange, flere endnu, hele Tuen var ganske mørkegraa. Luften var lutter lange, mørke Streger, Bladene nikkede og svaiede, og der kom en Susen, der gik over til Syden; det øste Vande ned”» (Kristensen I955: I20; «A typical impressionist description begins with the effect, the result of a "force", and only thereafter - or perhaps not even at all - arrives at the recognition of the force itself: "All of a sudden a small, round, dark spot appeared on the light-grey soil, one more, three, four, many, still more, until the whole mound was rather dark grey. There were sharp, 
An instance of the recording of raw, visual data in which the revelation of sense is deterred, can be found in Kleve's short story Vid Beau-Rivage. It occurs at the moment of a pivotal encounter between the tale's two protagonists. At dusk, the woman is waiting for her fiancé under the branches of a tree and, as the man appears, the reader is brought into her consciousness in the very instant in which she perceives his presence: an approaching shadow with a burning dot. Kleve takes care to deliver the description without translating the visual data to the reader, but according to the manner in which the onlooker takes cognizance of it. Accordingly, both the fictional observer and the reader fully grasp the sight only after it has been filtered through the act of reflection of the observer: «Skuggan med den brinnande punkten kommer närmare - - / - - Åh, Jack, röker du?» (I886d; «The shadow with the burning dot is approaching - - / - - Oh, Jack, do you smoke?»).

By giving primacy to the visual impression over intellectual understanding, this narrative technique - of which Watt spoke as 'delayed decoding', Ford as the 'uncorrected chronicle' and Møller Kristensen as an aspect of 'phenomenological apperception' - remains loyal to the principles of impressionist perception. As such, it is a strategy of description that works well with the scenic method characteristic of Herman Bang's poetics of impressionism, which strived to limit the reader's insight into the narration to as much as could be grasped through the observation of surface phenomena, an aspect, as we have seen, that also appears central to Kleve's declination of the impressionist mode.

\subsubsection{Punctuation}

As observed above with reference to Berta Funcke's reflection on the function of the gaze in a quotation from the homonymous novel, there are metafictional comments to support my line of interpretation according to which impressionist modes of narration serve the purpose of probing the improbable. Similar observations are present also to highlight the use of punctuation in the novel, which, as many of the above-quoted passages testify to, include a generous exploitation of dashes to organize the discourse. In the following metafictional observation from Berta Funcke, Kleve suggests that the novel's very modern subject matter can only be grasped through silences that suggest meaning, and pauses which have to be filled in by the reader:

der låg ett egendomligt äggande nöje i att tala om dessa "moderna” ämnen med en man. Detta, att akta sig för hvart ord man

long, dark streaks in the air, the leaves assented and shivered and there was a sudden southward wind; water poured down»). 
säger, att vara tvungen att göra hundrade uppehåll och låta meningar ligga qvar utan slut. Att hela tiden röra sig vid gränsen mellan det, som "går an" att säga, och det som "icke går an" - och att ändå aldrig öfverskrida den. (I885a: 32)

there was a strangely thrilling pleasure in speaking about these "modern" subjects with a man. The idea of having to watch every word carefully, to be obliged to make hundreds of halts and leave sentences unfinished. Of having to toe the line between what "can" be said and what "cannot" be said - and never cross it.

While I do not wish, simply because I do not think it takes us very far, to compare aspects of Kleve's punctuation to the technique of the impressionist painters - in a manner similar to that in which Maria Elizabeth Kronegger (I973a: 83) treats punctuation in a comment on Jules Laforgue's prose by claiming that «the great number of commas has its equivalent in the impressionist's broken brushstrokes», or to Birgitta Ney's (I993a: I4I) allusions to parallels between Kleve's typographical technique and Morisot's brush movements on canvas - I would still argue, in accordance with Møller Kristensen, who discusses the use of the dash as «et vigtigt stilmoment $\mathrm{i}$ impressionismen» (I955: 97; «an important stylistic trait of impressionism»), that these typographical choices should be connected to the impressionist style. As suggested by the metafictional comment quoted above, the unspoken words and half-finished sentences primarily serve to indicate that there is, in fact, more to tell than meets the eye. Lingebrandt writes:

Satser som tonar ut med ett eller flera tankstreck är en stilistisk markör för de halvkvädna visorna. Likaså vimlar dialogerna av oavslutade meningar och löst utkastade ord, av toner och undertoner. Det är ett slags språkligt maskspel där allt väsentligt egentligen utspelar sig mellan raderna. (201г: 47)

Sentences that fade out into one or more dashes is a stylistic marker indicative of half-recited tunes. Similarly, dialogues are overflowing with unfinished sentences and loosely connected words, with tones and undertones. It is a form of linguistic play with masks, in which everything essential really takes places between the lines.

Apart from suggesting the text's deeper, and different, meaning, the dashes also indicate the author's wish to reproduce a more natural dialogue capable of revealing the characters' personalities and, as such, this aspect of the narration reconnects to the scenic impressionism that has been dis- 
cussed in the above as one of the dimensions of Stella Kleve's impressionism. Torbjörn Nilsson's (1965: 105) reading of Bang's use of dashes and ellipsis points as an expression of how impressionism's dramatic method tries to grant autonomy to the action which has been set in motion, moves in the same interpretive direction.

\subsubsection{Conclusions. Probing the improbable}

Flirtations, the short story with which Stella Kleve introduced herself to a Scandinavian readership, set, on its own, the tone for her reputation as a writer dealing with controversial narrative material. In a letter to her sister Ellen, dated 20 December I884, the author claimed that the subject dominating her prose was «erotika, naturligtvis» («erotica, naturally»), presented in the form of fantasies, never quite realized, but still as an important facet of the female identity ${ }^{15}$. The short story's protagonist, Berta Funcke, plays the part of a seducer fighting against her own erotic desires, and keeps on fighting - perhaps even harder, according to Birgitta Ney (I993a: 7I) - in the homonymous novel that followed. Suppressed, yet disquietingly evident, is the female eros in her stories, so much so that Karl Warburg's comment on Berta Funcke must be seen as indicative of this unsettling quality of her text: «det "händer" alldeles intet i vanlig mening "osedligt" $\mathrm{i}$ hela boken, och dock är skildringen något af det otäckaste man gärna kan läsa» (qtd. in Ney I993a: 77; «nothing "indecent" in a conventional sense really "happens" in the book, and still it is one of the nastiest accounts one can ever read»). What Warburg perceives is the absence of action illustrating the "inconvenient" argument of women's sexuality, an absence which is compensated perhaps even sublimated - by the delving on details as a way of fleshing out what Brigitta Ney (I993a: I27-28) calls the «erotic signals» in the text. In line with Ney's and Lingebrandt's observations on Kleve's art of fiction, I have argued that the author's concentration on fragments reveals a submerged female universe in turmoil.

By focussing on surface phenomena, Kleve thus points to the profundity of the narrated woman's self; a self inclusive of erotic pulsations, as in the portraits of Berta Funcke or Märta Ulfklo, in Pyrrhussegrar. In addition, my line of reasoning pushes the discussion further by maintaining that this inconvenient argument was brilliantly countered by Stella Kleve through the adoption of impressionist narrative modes allowing her to probe the improbable. This interpretation of Kleve's impressionism differs from Pil Dahlerup's opinions on Kleve's impressionism as well as from Birgitta Ney's rather lengthy discussion of «vad en läsning av hennes [Kleves] verk i impressionismens ljus och energi kan tillföra» (Ney I993a: I36; «what a

I5 The letter is partly quoted in Ney I993a: 53. 
reading of her authorship in the light and energy of impressionism might add»), in which the stress on 'light' establishes, as we have seen, a few, not quite convincing, parallels to impressionist painting ${ }^{16}$, while the 'energy' identifies with a «nervous style» and «demonic passion» and marks the author's proximity to decadentism (Ney I993a: I6I). My argument has tried to prove that Kleve, while remaining true to the dramatic method outlined in Herman Bang's poetics of impressionism, was able to scrutinize the taboo of women's erotic fantasies by concentrating on actions, behaviour, gestures, and mimicry visible from the outside. On the subject of Bang's impressionism, Dag Heede (2003), as we have seen, has defiantly advanced the possibility of considering literary impressionism a 'homosexual' narrative techninque, suiting the needs of an author who had to recur to extremely subtle devices to allow his themes expression. Stella Kleve's choice of subject matter placed her in the same 'outsider' position as Herman Bang, and she fell back on the same kind of discreet, unobtrusive narrator and on a behaviouristic character description that allowed her to speak of female desire, an argument, at the time, as inconvenient as homoeroticism. Her literary project of 'probing the improbable' was further fuelled by an impressionist strategy of description that I have referred to as the metonymic mode: an art of showing that an apparently trivial fragment is capable of hosting a world of significance. The devil, it is said, is in the details.

I6 In addition to the examples quoted earlier, Ney disregards textual indications in her search for pictorial parallels when claiming, on the subject of scene, in the short story Hendes Durchlauchtighed: «även om texten anger att den [scenen] liknar en medeltida målning har den ändå ett ljus- och färgspel från impressionismen i aftonsolens rodnande ljus» (I993a: I44; «although the text says that it is similar to a medieval painting. It still shows a play with light and colours typical of impressionism in the blushing reverberation of the evening sun»). 



\title{
4 . \\ A CRITICISM OF CRITICISM: GEORG NORDENSVAN AND MIKAEL LYBECK
}

\begin{abstract}
As a conclusion to the discussion regarding the modes of literary impressionism in Swedish prose, I will turn back to the results stemming from my critical survey of the use of the term in the Finland-Swedish press, presented in the preceding chapter of this study. By subjecting Georg Nordensvan's collection of short stories Skuggspel. Tidsbilder and Mikael Lybeck's novels Den starkare and Allas vår Margit to closer scrutiny, I wish to evaluate the appropriateness of the contemporary critics' view that these texts were representative of literary impressionism. To what extent do these pieces of prose relate to impressionist modes of writing? Which are the narrative traits in these texts that justify the connection?
\end{abstract}

\section{I. GEORG NORDENSVAN'S SKUGGSPEL. TIDSBILDER}

As mentioned earlier, in a review of Skuggspel. Tidsbilder for Nya Pressen on 3 November I884, Gustaf af Geijerstam - one of the early Swedish critics capable of phrasing the relationship between impressionist aesthetics and literary writing - delivered the definition «impressionistiska novelletter» (Geijerstam I884; «impressionist short stories») with regard to Nordensvan's short story collection ${ }^{\mathrm{I}}$. In his review, Geijerstam made it clear that

I In his career as an art critic, Nordensvan started to publish articles on painterly impressionism the year before Skuggspel was published. In part III of the present work we will take a look at Nordensvan as a bewildered but attentive observer of impressionist art, receptive, in particular, to the methods and techniques of the impressionist landscape painters. In addition, ten years after the publication of Skuggspel, Nordensvan advanced a discourse on the aesthetics and techniques of impressionism in his short story Aja, which will also be discussed in the third section of this study as an example of Swedish prose featuring impressionists as fictional characters. Nordensvan's art criticism will here be related to the opinions on impressionism expressed by the characters in this short story. 
he had chosen this adjective with the precise intention of heralding that Nordensvan's literary method was indebted to impressionist painting and similar in technique: «impressionism, hvilket ju som bekant eljes egentligen betecknar en särskild riktning inom måleriet är just rätta ordet för att beteckna det skriftsätt, som Nordensvan här användt» (Geijerstam ı884; «impressionism, which, as is known, really refers to a particular current in painting, is the correct word with which to define the literary mode that Nordensvan here has made use of»).

This parallel to impressionist painting builds on what Geijerstam describes as a literary technique attempting to capture the essence of landscapes, interiors, and conversations by conveying barely the main features of the scenes, not the single details. Geijerstam's following lines inform us of the nature of Nordensvan's metonymic eye, which translates into a writing transmitting

glimtvis uppfattade naturscenier [sic], snabba rumsinteriörer, samtal, der jämt så mycket är uppfångadt och bibehållet, som behöfs, för att man skall kunna förstå dessa sammanträngda lifsskildringar, der de allmänna dragen tagits med ögonblicksfotografi, och detaljerna suddats bort. (Geijerstam I884)

natural scenery caught in glimpses, swift room interiors, conversations, from which just as much is reported and maintained as is necessary to make the reader understand these concentrated life stories, of which the general traits have been captured through instantaneous photography, and all details wiped out.

He concludes by maintaining that the assets of the book reviewed are to be found in Nordensvan's impressionist sensibility and in his outstanding technical ability: «dess teknik är utmärkt, och uppfattningen är isynnerhet känslig, såsom det höfves en impressionist» (Geijerstam I884; «its technique is excellent and the execution is particularly subtle, which is what it takes of an impressionist»). Of the fortunate moments when Nordensvan's impressionist talent best shines through, Geijerstam gives the following examples: «naturskildringar sådana som nyårsmorgonen, interiörer som boklådan eller teatern, lifsbilder i miniatyr som den om gamla fröken Julie eller om grosshandlarn och hans fästmö» (Geijerstam I884: «descriptions of nature such as the one concerning the morning of the first day of the year, interiors such as the bookshop or the theatre, life miniatures such as the one concerned with the old spinster Julie or the wholesaler and his fiancée»). Before scrutinizing these moments in the narration and integrating Geijerstam's observations on the text's impressionism with my own, it should be added that David Sprengel, a few years later, expressed similar 
opinions about Nordensvan's narrative technique in Skuggspel: «som skriftställare är han iakttagare, ögonblicksmålare, impressionist» (I902: 295; «as a writer he is an observer, a painter of instants, an impressionist»).

The twenty-five short tales that form the collection are all untitled and display themes such as social injustice, the reality of the underprivileged, married life, ennui, city life (dinner parties, visits to the theatre, reflections on the deceitful façade of the urban environment). Some of the short stories portray fairy-tale universes, at times fantastic, surreal, grotesque, or even Gothic in spirit. In the story depicting a bookshop at night, mentioned in Geijerstam's review of Skuggspel as indicative of Nordensvan's impressionist eye, characters from novels come to life in the hours of darkness only to return to their places inside the books on display as soon as the sun rises. Something similar occurs in the very last tale, set on the first day of the year, also included among Geijerstam's examples of Nordensvan's impressionism: during a sleigh ride through a wintry landscape, trees and bushes in the woods assume fabulous, suggestive shapes. Outright ghoulish and horrific are instead tales such as the one focussing on a moonlit operating theatre where a newly arrived skeleton reflects on his place in this new environment, as well as the story of a young mother who is forcibly interned in a psychiatric hospital after having killed her own child.

Geijerstam's vision of Nordensvan's impressionism as a prose producing instantaneous photographs in which a few, significant details are made to cater for the total impression, draws close to what I have described as 'the metonymic mode' on the subject of Stella Kleve. This narrative aspect can be observed, I believe, in those passages in the volume where Nordensvan indeed sets the scene by swiftly adding item to item to build up a picture, as for example in the opening lines introducing the collection's third tale: «nötta skolbänkar, slitna armbågar mot borden, böcker öfver allt, solen lysande in i en lång stråle, der dammet dansade. "Gubben" halfliggande i katederstolen med hufvudet stödt mot Afrikas karta, som hängde bakom honom» (Nordensvan I884: 8; «worn-out school desks, threadbare elbows against the tables, books everywhere, a long ray of sunshine filled with dancing dust motes, lighting up the room. The "old man" stretched out in his chair at the master's desk, with his head against a map of Africa pinned to the wall behind him»). Similarly, the two and a half pages composing the fourth story, not much more than a series of impressions pitting a lavish dinner party against a mass of labourers, on the one hand, and, on the other, against a bunch of soldiers, starts by briskly numbering a series of details representative of the scene:

Frisk klar luft, starkt sommarsolsken, som förgyller allt, jämnar, lifvar allt. Glittrande vågor i elfven, snömoln, som segla fram nere i sjöns spegel. 
Från den stora villan i schweizerstil ljuder festligt glam. Kristallerna skimra, vinet lyser i glasen, fem framför hvarje kuvert.

Upphetsade ansigten, röda, varma och sorglösa. Hvita skjortbröst, svarta frackar, den mest animerade sinnesstämning. (Nordensvan I884: I8)

Fresh clear air, bright summer sunshine that gilds everything, evens out, uplifts everything. Glittering waves in the stream, snow clouds gliding past over the mirror of the lake.

From the Swiss-style country house a festive sound is heard. The crystals shimmer, the wine gleams in the glasses, five for every setting.

Aroused faces, red, hot and cheery. White dickeys, black tailcoats, the most animated mood.

The tendency to prefer nominal phrases in this kind of passages is perhaps best observed in the opening to the concluding short story, set on the first morning of the new year. Nordensvan writes: «kallt och mörkt. Pelsen upp öfver öronen, fällen svept om fötterna, hästarna ludna, isade, med hvita moln om nosarna. Allting höljdt i snö, gärdesgårdarna djupt begrafna. Och skogen rundt omkring, tät, oändlig» (I884: I5I-52; «Cold and dark. The fur coat up to the ears, feet cloaked in the hide, the horses downy, icy, with white clouds around their muzzles. Everything shrouded in white, fences deeply buried. And the forest all around, dense, boundless»).

In addition to Geijerstam's reading of the metonymic impressionism at work in Skuggspel, the texts in Nordensvan's collection also present passages that connect to the scenic narration which can be seen as a variety of impressionism, as observed in the preceding section of the present work. Several passages are told in medias res (see for example Nordensvan I884: 6I, 90), and there are openings, as the one introducing a refined office at the beginning of the fourth tale, that clearly remind the reader of the stage instructions characteristic of what we have looked at as impressionist settings generated through the use of significant details in Stella Kleve's short story production:

Snidade panelningar, vapen på väggarna, venetianska speglar, ett svart väggskåp med barockgudinnor af silfver, gamla porsliner, och ett präktigt skrifbord i empirestil med fascer och gloende gripar. Böcker, gravyrer och små konstverk lite hvarstädes, en stoppad och bekväm arbetsstol, en panterhud under bordet - allt utvisande gedigen lyx och förfinad smak. (Nordensvan I884: I9)

Carved panelling, coats of arm on the walls, Venetian mirrors, a black cupboard with baroque goddesses in silver and antique 
porcelain hanging on the wall, and a massive desk, empire style, with sheaves and glaring griffins. Books, etchings and small artwork here and there, a padded desk chair, a panther skin rug underneath the table - all things indicative of great luxury and refined taste.

\subsection{MIKAEL LYBECK'S ALLAS VÅR MARGIT AND DEN STARKARE}

In the essay The Modern Breakthrough's Author and his Publisher: Mikael Lybeck and Werner Söderström, Roger Holmström presents Mikael Lybeck as «the only relatively important and well-known Finland-Swedish writer from the period of the Modern Breakthrough» alongside Karl August Tavaststjerna (Holmström I999: 336). According to Holmström (I999: 338-39), at the end of the I880s Mikael Lybeck was «best known for his review articles of Herman Bang's visiting lectures in the Finnish capital in the spring of I885». However, it is quite clear that Lybeck's interest for Bang did not comprise an appreciation of those voices that attempted to set up stylistic analogies between his own prose and that of the Danish impressionist. In his examination of the correspondence between Lybeck and his publisher, Holmström quotes from one of Lybeck's letters to Söderström, who had asked a reader for an opinion on the I89 novel Unge Hemming (Young Hemming). In the letter, Lybeck is truly resentful towards the reader's assessment according to which his prose was reminiscent of Bang's:

Hvad är det för prat om Bang! Min obekante vän känner inte mycket nämnde skriftställares afstympade meningar, om han vill dra honom till jämförelse. Mina meningar äro ofta korthuggna, det är sant, men de ha i regel subjekt och predikat - och saknas någondera någon gång, t.ex. i en tanke-monolog (om jag så får säga), så är det afsiktligt. [...] Bang! Nej, är det påvärkning i någon mån så är det af Lie eller Garborg. (I999: 348-49; italics in the original)

What's all this nonsense about Bang! My unknown friend does not have much knowledge about the mentioned writer's mutilated sentences, if he's a mind to draw a parallel between us. It's true my sentences are often short but as a rule they contain a subject and a predicate - and if either of them is sometimes missing, for instance in the soliloquy of thoughts (if I may say so) it is on purpose. [...] Bang! No, if there are any slight influences they come from Lie or Garborg. (Translation by Roger Holmström I999: 349) 
As we have seen, however, in spite of the writer's personal outcry, the critics would repeatedly insist on the artistic fellowship between Lybeck and Bang, comparing the I894 novel Allas vår Margit to Bang's Tine (I889) and attributing it to the literary impressionist school because of what was seen as similarities with Bang's scenic narration. In the earlier quoted anonymous review of Allas vår Margit, Lybeck draws the short straw in the reviewer's comparison as he fails to remain faithful to objective character description throughout the novel, and because this impressionist technique is not deemed to suit the action in the novel:

Den tillhör den impressionistiska riktningen, skildrar väsentligen blott hvad man ser och hör, utan att närmare redogöra för de uppträdande personligheternas förhållanden, motiv eller karaktärer eller lägga dessa fram i och genom handlingarne. [...] Ett dylikt stilla småstadslif, som här förekommer, egnar sig mindre än något annat för impressionistisk skildring. Det skall vara mera händelserika, rörliga och lifliga förhållanden, som skola kunna uppehålla en skildring af detta slag. Det enda vi förut ega i den nordiska literaturen, som ej är misslyckad, ehuru äfven den kan gifva anledning till olika omdömen är Herman Bangs Trine [sic], men denna har också just till hufvudmotiv de upprörda dagarna vid Dybböls fall och Als' eröfring. (I894 'Literatur o konst')

It belongs to the impressionist movement and reproduces primarily only what one sees and hears, without accounting in detail for the relationships among the characters involved, the motives, or the personalities, that are instead introduced in and through the actions. [...] The quiet small-town life that we are presented with is much less suitable for an impressionist rendering than anything else. What is needed to sustain this kind of story-telling are dynamic, animated, and lively conditions. The only successful example in Nordic literature of such a description is Herman Bang's Tine of which there are many opinions; this novel, however, still has as its main motif the savage days before the fall of Dybbøl and the conquest of Als.

On the other hand, as we also have seen, another anonymous critic willingly admitted that Lybeck's Den starkare from igoo revealed resonances of literary impressionism, a style perhaps somewhat outdated, but still executed in a manner more convincing than Bang's:

Det på en gång lugnt och nervöst impressionistiska framställningssättet [...] värkar som en hälsning från tio år tillbaka, ett dy- 
likt skrifsätt är ej modernt nu i dag, men det hindrar inte att det visar sig vara lifligt målande, och det blir här ej tröttande, som det onekligen varit hos en och annan af denna stils typiska företrädare, Herman Bang till exempel. (I900 Om Mikael Lybecks)

The calm and at the same time nervous impressionistic rendering [...] comes across as a souvenir from ten years ago; this way of writing is no longer modern today, but that does not stop it from being lively and evocative, and in this case it does not become tiring, as undeniably has been the case in some of the representatives of the style, as for example Herman Bang.

That said, I will not attempt to argue that what can be seen as impressionist writerly techniques in Lybeck's prose are textual characteristics carried out evenly and consciously throughout these two novels. However, it must be admitted that the central episode in Allas vår Margit, namely the protagonist's loss of her mother, is capably rendered with stylistic elements faithful to scenic impressionism, such as limited point of view, the retreat of the intervening author, in medias res. On the first page of the novel the reader is introduced to the key scene featuring five-year-old Margit and her dying mother. The story opens with a narrator unwilling to guide the reader through the text and by rendering the impressions accessible to the individual mind of the little girl, who perceives a faint voice seemingly emerging from the shadows:

En mycket svag, nästan hviskande röst frågade ur skymningen:

Hvem är det?

Det är Maggie.

Vill du något?

Utan att svara sprang en vacker femåring öfver tröskeln och fram till hvilstolen.

(Lybeck I893: 5)

An extremely faint, almost whispering voice asked from the gloom:

Who is it?

It is Maggie.

Do you need something?

Without answering a beautiful five-year-old leapt over the threshold and up to the resting chair.

Throughout the novel, this scene is reiterated both in Margit's memory and in her dreams, and always with the same vagueness and uncertainty regarding perception and source. In a dream, the adult Margit attends a party 
and all of a sudden what seems to be the same voice is raised:

En röst höjde sig öfver sorlet och frågade:

Hvem där?

Maggie.

Vill du något?

(Lybeck I893: 54)

A voice emerged from the noise and enquired:

Who's there?

Maggie.

Do you need something?

If the reason for the unfavourable criticism of Allas vair Margit was that a quiet small town life is not suitable for an impressionist rendering, it must be admitted that Lybeck could have treated the only really dramatic episode in the novel - the fire in chapter eight - or the description of the crowd at the ball in chapter eleven differently, had it been his intention to make the most out of impressionist techniques of writing. That he did possess the technical ability of an impressionist is however evident in certain descriptions present in the novel Den starkare. In this novel, a scene set at the railway station offers a brilliant impressionist narrative solution to the registration of dynamism, animation, and simultaneity, indeed reminiscent of Stella Kleve's technique in Berta Funcke, commented on earlier:

Korta hvisslingar, hvassa som knifsudddar, långa, ihållande signaler - ljussken blixtra förbi fönstren i kvällsmörkret, det knäpper i skenfogarna, vaggonerna darra och rycka vid bromsningen, och lokomotivet stannar för att frusta ut hvit ånga åt båda sidor. Dörrarna slås upp för folk i snövåta pälsar, armbågar bana väg i trängseln, smått och stort resgods myllrar för fötterna.

[...]

Då sätter sig tåget långsamt $\mathrm{i}$ gång. Igenkänningsscener växla med dumt stirrande, tidningar vecklas ut och vikas samman, cigarrer tändas, tuggas, slockna och tändas på nytt. Någon frågar efter spelkort. Hva-fan ... det är ju alldeles för trångt! Ventilerna i taket undersökas och skrufvas, kinderna bli heta och röda, luften blir rök. Men färden fortgår som förut - nya hvisslingar ljuda, nya ljusglimtar jaga hvarandra, ny station! (Lybeck I900: 44)

Short whistlings, sharp as knife-ends, long, insistent signals blazes of light flash past the windows in the dusk, the rail joints snap, the wagons tremble and jerk as it pulls in, and the locomo- 
tive stops to snort out white steam from both sides. The doors open for people in fur coats wet with snow, elbows make their way into the crowd, luggage small and large swarm at their feet. $[\ldots]$

Then the train slowly sets off. Scenes of recognition mingle with vacuous staring, newspapers are unfolded and folded, cigars are lit, chewed, they go out only to be lit again. Someone asks for a game of cards. What-the-hell... it is much too crowded! The fans in the ceiling are examined and tampered with, cheeks go red and hot, the air turns into smoke. But the journey continues like before - new whistlings ring, new blazes of light chase one another, next stop!

The central, 'naked', line with its colloquial features is unintroduced by the narrator and pronounced by an unidentified character. Similar attempts to use a submerged narrator while granting greater space to the specificity and spontaneity of expression of characters can be observed later in the novel, as the narration, by accumulating impressions, details, and indirect speech helter skelter, focusses on the commotion characterizing the days following the death of the protagonist's father:

Redan när sköterskan reste, och det skedde morgonen efter dödsfallet, anlände från staden en mager, liten fru i svart bindmössa, tre eller fyra hjälpkvinnor med henne. Låt vara, att endast bärarna inbjudas ... herrejess, det fans ju ändå så mycket att städa och ställa i ordning, så mycket att efterse, att hvad som måste göras, måste göras strax; det viste hon, herrejess, hon har varit där förr. - Alla mattor äro uttagna, golfven lysa rena och nyskurade. Lukten af hackadt granris fyller rummen.

Bjällror!.. barhufvad springer Abel ut på trappan. (Lybeck I900: 160 )

Already as the nurse departed, which happened the morning after the decease, a skinny little lady with a black hat tied under her chin arrived from town in the company of three or four helpers. What did it matter that only the carriers should be invited... my dear, with so much cleaning and ordering to be done, so much to look after, what had to be done had to be done immediately; that she knew, my dear, she had been there before. - All carpets have been brought out, the floors shine spotless from recent scrubbing. The smell of chopped pine branches fills the rooms.

Bells!.. with no cap on his head Abel runs out the door. 



\section{5 .}

\section{SUMMARY}

In bringing to a close this section concerned with avoiding a «casual and descriptive» (Watt I980: I72) use of the term literary impressionism by presenting examples considered apt to illustrate forms of impressionist fiction in Swedish prose, I would like to stress the directions in which the investigation has moved and the results of the textual analyses carried out. Although the point of departure has been the two common interpretations of literary impressionism in the international debate, i.e., literary impressionism as a transposition of pictorial subjects, means, and methods to words, firstly, and as rendering of impressions, secondly, the examples chosen for discussion have allowed me to break some new ground. While Helena Westermarck's short story Aftonstämning has opened a sealed box within the decoding of literary impressionism in Scandinavia, namely the one containing ekphrastic discussions of texts acting as impressionist paintings, Stella Kleve's narrative art, which provides examples of scenic impressionism as well as of the refined narrative device of 'delayed decoding' (taking the reader directly into the consciousness of the observer at the instant of the not-yet-intelligible, raw, perception), has allowed me both to abide by the extensive use of the term encountered in the Scandinavian debate on literature and impressionism, and connect to the international debate on impressionist perception in writing, as understood by Ian Watt.

Lastly, the attempt to scrutinize the ways in which literary critics extended the terms 'impressionism' and 'impressionist' from painting to prose, has brought me back to two of the more substantial critical comments discussed in the critical survey exposed in part I. I have focussed on examples of criticism in which these terms were used in ways that go beyond their popular and casual application. In the examination of what substance there was to the critical views according to which the narrative techniques in Georg Nordensvan's Skuggspel and Mikael Lybeck's Allas vår Margit and Den 
starkare involved an adoption of literary impressionism, I have found that passages in Nordensvan's short story collection are concerned with the metonymic mode and with an approach to settings that recall the scenic narration characteristic of Herman Bang's impressionism, whereas Lybeck's narrative method in the two novels under scrutiny, at times, significantly in the climactic moments of the story, shows a preoccupation with the perceptions of the individual consciousness that does away with the all-knowing and all-seeing narrator. 
PART III

FICTIONAL IMPRESSIONISTS 



\section{I.}

\section{INTRODUCTION: THE IMPRESSIONIST AS A LITERARY CHARACTER}

In an attempt to complete the discussion of the writers' awareness of impressionism, we will in this last section turn to the representation of the impressionist as a literary character in Swedish fiction. I will examine a body of four little-known texts written at the close of the nineteenth century, casting the impressionist in the role of protagonist or minor character: Gustaf af Geijerstam's tale Utan pängar (Moneyless) from the collection Fattigt folk (Poor People), II, I889 (Geijerstam I889)'; Mathilda Roos's novel Familjen Verle. En skildring (The Verles. A Tale), also published in I889 (Roos I889); Georg Nordensvan's short story Aja, first published as a feuilleton in the review Idun in $1894^{3}$ (Nordensvan $\mathrm{I} 894 \mathrm{~b}$ ) and later that same year printed, with a few changes in the text, in his Tre små romaner (Nordensvan I894a; Three Little Novels); and, lastly, K.A. Tavaststjerna's Impressionisten (The Impressionist), included in his volume of short stories Unga år (Youth), 1892.

Conny Svensson's mapping of the artist novel of the I88os (Svensson I985) offers an excellent inventory of the artists populating Swedish fiction in this decade, and also charts the rare impressionist painters that appear in the genre ${ }^{4}$. While Svensson's monograph has significantly facilitated the

I Also available at https://litteraturbanken.se/forfattare/GeijerstamG/titlar/FattigtFolkII/ sida/ı87/etext. Accessed 25 January 2018.

2 Also available at http://hdl.handle.net/2077/372I8. Accessed 25 January 2018.

3 The I894 issues of the review are available online at http://www.ub.gu.se/kvinn/digtid/07/1894/index.xml. Accessed 25 January 2018.

4 Besides the above mentioned tales, which will be more closely examined in the following paragraphs, Svensson points to only one more possible, though implausible, nineteenth-century contribution to Swedish fiction featuring a discourse on impressionist art, namely a short story by Ernst Ahlgren entitled Kritik (Criticism). According to Sten Linder, as Svensson points out, this short story testifies to Ahlgren/Benedictsson's sympathy for «den impressionistiska opponentkonsten» (Svensson I985: 210; «the impressionist art of the opponents»). Assuming that this comment draws on a single episode in the text (the dialogue in the boat), during which 
singling out of the texts central to the issue investigated here, I also wish - in an effort to frame the fictional impressionist while remaining true to the spirit of the present study, which sets out to present resonances and modes of impressionism in literature - to consider a tale articulating concern over the fact that impressionism is not merely about modern subjects in painting and new artistic techniques. As we have seen, literary impressionism cannot be reduced to verbal pictorialism and pictorial methods emulated in writing only: accordingly, the painter is not the sole impressionist character to whom we should direct our attention. The hypersensitive protagonist featuring in the fourth text dealt with in this part of the study, K.A. Tavaststjerna's Impressionisten, is in fact not an artist, nor is the writer striving to find a verbal equivalent to the visual art of the impressionists in his prose. At first glance, the interest in the novella lies in the choice of title, which, all the more, foreshadows a story true to the very heart of impressionism in revealing a protagonist with a firm belief in the primacy of sensory perception. It is my conviction that this short story then offers us the possibility of exploring the 'phenomenological impressionist' and the essence of impressionism as a perceptive experience.

the art of the opponents is casually brought up in conversation, Svensson judges Linder's interpretation highly unlikely since expressions of the author's sympathy for the avant-garde is nowhere else to be found (2II). 
2.

\section{THE PAINTER IN FICTION}

The painter in fiction is a motif that has long since inspired scholarly writing internationally. Besides the wealth of shorter critical essays on single literary works featuring artists, among the more consistent critical monographs uncovering the painter as a literary type are Theodor R. Bowie's The Painter in French Fiction (Bowie I950); Maurice Beebe's Ivory Towers and Sacred Founts. The Artist as Hero in Fiction from Goethe to Joyce (Beebe I964); Herbert Marcuse's doctoral dissertation from I922, Der deutsche Künstlerroman (The German Artist Novel) published in German in 1978 (Marcuse I978); Ernst Kris and Otto Kurz's Die Legende vom Künstler from I934 (here referred to in the English translation, Legend, Myth and Magic in the Image of the Artist; Kris and Kurz 1979); the volume edited by René Démoris, L'Artiste en représentation (Démoris I993), and Émilie Sitzia's doctoral dissertation L'Artiste entre mythe et realité dans trois oeuvres de Balzac, Goncourt et Zola (Sitzia 2004). As to the Scandinavian scene, a rather recent contribution to the field is Paul Binding's exploration of the representation of artists in Ibsen's production, With Vine-leaves in His Hair. The Role of the Artist in Ibsen's Plays (Binding 2006). Conny Svensson's aforementioned study presents an excellent introduction to Swedish examples belonging to the genre of the artist novel; while exhaustively outlining the specificities of the konstnärsroman of the I880s, an in-depth analysis of the impressionist painter in fiction falls, however, outside of its scope.

To the best of my knowledge, very few scholars have scrutinized the representation of impressionist art and artists, specifically. One of these is Anna Gruetzner Robins in an essay dedicated to British writer George Moore and his I883 novel A Modern Lover (Gruetzner Robins 2007), another is Sarah Brun, who has examined two French plays, La Cigale and Les Impressionnistes, introducing impressionist characters (Brun 20I2). That scholarly attention to this topic is limited is perhaps not surprising as the repertory of interna- 
tional narratives featuring fictional impressionist painters, within our given period, seems likewise not particularly abundant and would include, among the best-known examples, characters such as Marcel Proust's Elstir in À la recherche du temps perdu (I909-22), whose impressionism is discussed in Valazza (2013: 30I-09), Rudyard Kipling's painter-protagonist Dick Heldar in The Light that Failed from I891, and Stephen Crane's Will Hawker in The Third Violet, published in I897. Fellow impressionists to the Swedish specimen examined in the following can also be found in Philippe Burty's Grave imprudence of I880, and in Edmond Duranty's short stories forming the collection Le Pays des Arts, published in I88I (cf. Johnson I973: 27I) ${ }^{\mathrm{I}}$.

The sporadic impressionists in Swedish prose written and set in the impressionism era are grouped together here in order to scrutinize the idea of impressionist art and the vision of the impressionist artist that come forth through the texts ${ }^{2}$. When the impressionist appears as a literary character,

I The shortage of impressionists in the Swedish artist novel may well depend on the absence of models in the contemporary art world. According to Torsten Gunnarsson (2002: 25), with the single exception of Anders Zorn, impressionism was nothing but an «episode» on the main road leading Swedish painters, such as Karl Nordström, Per Ekström, and Carl Trädgårdh, from realism to symbolism. In volumes of Finnish art history, the absence of artists outspokenly impressionist is sometimes explained with the statement that Finland lacked a modern metropolitan culture, the very climate on which impressionism thrived (see, e.g., Lindberg I998: I74). Sixten Ringbom also writes that impressionism seems to have disappeared in the wave of symbolism which at the turn of the century came to serve Finnish nationalism also in the art world: «Av de senare riktningarna hade impressionismen (ca I874-86) passerat tämlingen oförmärkt bland våra konstnärer; det är bara i några enstaka ekon hos Edelfelt och Westerholm som intryck av målare som Manet och Degas gör sig gällande. Icke så med symbolismen - denna parisiska 9o-talsriktning skulle hos oss utlösa krafter som stod i tjänst hos den nationella idé som dominerade ı800-talets finländska konstliv» (Ringbom ı998: 2ı6; «Among the later currents, impressionism [ca. I874-86] had passed without our artists giving it greater attention; only sparse echoes originating in painters such as Manet and Degas can be observed in Edelfelt and Westerholm. This is definitely not the case with symbolism - this Parisian current of the 1890 s that would come to release energies serving the nationalistic idea dominating the Finnish art world in the nineteenth century»). Given the shortage of impressionist painters in Finnish art history, it is perhaps not surprising that fictional counterparts should be almost absent in literary writing.

2 None of the authors that are of interest to this part of the present survey indicate the temporal setting of their stories with a precise year. The unfolding of the action, however, allows the reader to trace the events, in Geijerstam's case, to the years before impressionism won acceptance in Sweden as well as in Paris. Mathilda Roos's novel most likely takes place some time later, in the years when naturalistic painting as well as national subjects were beginning to seem outdated and French impressionism had reached its peak. Nordensvan's short story Aja covers a time span of six years, beginning in the years when French impressionism was still in bloom and ending as symbolism and synthetism were making their entrance into the art world, i.e., in the second half of the I880s (cf., Gunnarsson 2002: 36). Tavaststjerna's short story unfolds «innan impressionismen kommit på modet som konstart» (Tavaststjerna I892: II; «before impressionism had become a fashionable movement in art»). To help locate these narratives in time, it could be added that impressionism, with the exception of those few painters who early on came into direct contact with the French forerunners (e.g., De Nittis, Zandomeneghi, Cassatt) did not spread internationally before the end of the r88os (cf., Hedström 2002: 70). 
does the writer's portrayal mirror the general opinion of the artists belonging to a movement that found it hard to win acceptance? Is he misunderstood, scandalous, poor, ill-fated, in conflict with his surroundings or, on the contrary, ground-breaking, admired, successful, and envied? Is there a wish to attack or defend his art? What is his role? Where does he live and breathe? ${ }^{3}$

Secondly, and as to the motif of the artistic discourse, we will take a look at the rendering of the technical and aesthetic theories. This field of investigation is particularly interesting when attention is given to authors with a double talent: apart from their activity as novelists and short story writers, Georg Nordensvan and Gustaf af Geijerstam also worked as art critics, which is of relevance to the discussion as it signifies that they had a factual connection to the art world and the knowledge necessary to judge and interpret trends in painting ${ }^{4}$. Evident in the short stories of both Geijerstam and Nordensvan is the accuracy in terminology, probably deriving from their parallel activity as art critics and art historians. Where present, narrative remarks and observations on the impressionist-protagonists' landscape paintings with their 'unnatural' blue colour, on the impressionist's endeavour to seize «ögonblicksstämningar» (Nordensvan I894b: I35; «atmospheres of the moment») and achieve a 'total effect', to mention a few examples, are wholly consistent with the ideas of the French innovators, whose blue shadows and refusal to dwell on details in favour of the rapid capturing of the essence of the subject quickly became something of a hallmark. Is art criticism therefore embedded in the writer's choice of character?

\section{I. GUSTAF AF GEIJERSTAM: UTAN PÄNGAR}

The title of Geijerstam's tale introduces the reader to what Theodor R. Bowie (I950: IO) has defined as «perhaps the most pressing problem» to the painter in French fiction; the motif is that of the starving artist, battling with the need to feed his body while saving his soul and artistic vision.

The location of Ivar Melin's atelier, determined in the opening line of the short story to «långt bort på Boulevard Montparnasse» (Geijerstam I889: I89; «the farther end of the Boulevard Montparnasse»), places this Swedish painter among the emigrant artists who inhabited a cheaper and less romantic neighbourhood than the old artistic heart of the city that it would soon come to replace, i.e., Montmartre, where Melin's fellow artists are said

3 The impressionist painters in the Swedish literary works considered here all have a connection with Paris. As is known, impressionism was essentially an urban art and, it must be added, specifically a Parisian art, profoundly tied to the rapid developments of this city, which by the mid-nineteenth century had turned into the cultural capital of Europe.

4 Geijerstam was an amateur reviewer of art (cf., Svensson I985: 22I), while Nordensvan is the author of a great many classic works on Swedish art history. 
to reside (235: «han gick uppåt Boulevard Clichy där kamraterna bodde»; «he went up towards Boulevard Clichy where his companions lived»). This piece of information places the protagonist ahead of his time ${ }^{5}$. It also possibly stresses his fervent desire to break with artistic tradition and adhere to the radical impressionism ${ }^{6}$.

Although the initial characterization of the painter-protagonist is formulaic, portraying Melin with the stereotypical attributes of the (unsuccessful) artist: Basque-style beret; yellow straw chair; empty wallet, Geijerstam soon sets the tone for a narration that is original in the way it resonates with the aesthetics of the picture-seeking eye peculiar to the impressionist. Despite the fact that the drama unfolding in the story (covering a period of two days in the life of the artist) is profoundly imbued with the topoi of economic hardship and misery - both commonly employed in the art novel and often connected to the age-old idea that a life of poverty and privation is the lot of the artistic genius (Kris and Kurtz I979: II4) - the narrative units mediated through the impressionist's «inspirerade målaröga» (Geijerstam I889: I90; «inspired painter's eye») are, for the purpose of my discussion here, the most significant point at issue in Utan pängar. Embedded within the protagonist's frequent hunger-ridden reflections on the relationship between money and art are smaller narrative sequences seen through the protagonist's perspective, in which the focalized objects appeal to the impressionist's sensibility in at least two ways.

On the one hand we find internal focalizations on aspects of the surrounding reality, such as flooding light, enticing Melin because of their pictorial value; on the other, through the protagonist's observations of the ur-

5 Conny Svensson defines Melin «en förnyare och framtidsman inom måleriet» (I985: 228; «an innovator and a man of the future within painting»). Ivar Melin thus belongs to those young Swedish artists who, starting from the I870s, favoured France over Germany (Düsseldorf) for their studies abroad, abandoning the taste for «ett romantiskt, idealistiskt folklivsmåleri» (Hedström 2002: 48; «a romantic, idealistic painting of the life of the lower classes»).

6 That the contemporary readership understood the protagonist to be representative of the impressionist school of painters is confirmed by the review C.G. Estlander dedicated to Fattigt folk II (Estlander I890). As previously mentioned, in his review Estlander commented on the moment when Ivar Melin finally succeeds in selling a painting in terms suggesting that by 1890 , in Scandinavia, a consensus on the value of impressionist art had at last been reached, at least in the eyes of a perspicacious connoisseur like Estlander: «troligen går det honom sedan mycket bra, impressionist som han är» (Estlander I890: 62; «being an impressionist he is subsequently probably very successful»). Conny Svensson also points out «i förbigående» (228; «in passing») that «Melin troligen är den första uttalat impressionistiske målaren som uppträder i svensk skönlitteratur» (Ibidem; «Melin is likely to be the first outspokenly impressionist painter to appear in Swedish fiction») and adds that this fictional character probably was modelled on the Swedish painter Karl Nordström, whom Geijerstam had befriended in Grèzsur-Loing in I884: «hans roll motsvarar [...] den som i verkligheten spelades av Geijerstams vän Karl Nordström, betecknad som den förste impressionisten i svenskt måleri» (222; «his role corresponds [...] to the one that in reality belonged to Geijerstam's friend Karl Nordström, defined as the first impressionist in Swedish painting»). 
ban scene, the reader is given access to this character's distinctive manner of 'framing unframed compositions' during his city walks: «med målarens glädje åt färg och lif kunde han tillbringa timmar och dagar på dessa gator, flanerande utan mål, njutande af dessa friska taflor utan ram» (239; «with a painter's delight in colour and life he would spend hours and days in these streets, strolling aimlessly, relishing in these unsullied, unframed paintings», italics are mine). In spite of the indication according to which Melin experiences certain urban scenes literally as «unframed paintings», these textual descriptions are essentially unpictorial as far as writerly techniques are concerned (unlike the case of Westermarck's Aftonstämning, previously examined) but, as to the subjects framed, it appears fruitful to examine these passages as patterned after impressionist canvasses, not least because of this authorial suggestion.

By focussing on a few examples, I will try to illustrate how the narrative units that appeal to the impressionist's pictorial imagination function in the text. As previously mentioned, they fall into two categories: for clarity, I shall discuss the passages dwelling on light effects as 'a pictorial approach to the observation of reality'. Subsequently, the scenes impressed on the narrator's mind as he saunters through the streets of Paris, rendered in a manner similar to that of cutting impressionist canvasses out of their frames, will instead be defined as 'a literary approach to impressionist subjects'. The question of what function these units perform respectively will be addressed with reference to Marianna Torgovnick's reflection on the use of the visual arts in literary writing, in which the concept of a 'decorative' use (Torgovnick I985: 70-Io6) seems particularly relatable to Utan pängar.

I will conclude the discussion by identifying an instance of pictorialism in the narration that differs from the above: the ekphrastic description of Melin's own landscape painting moves beyond the ornamental function in all its varying degrees, and informs the reader more accurately of Geijerstam's understanding of the essence of impressionist art.

\subsubsection{A pictorial approach to the observation of reality}

As a confirmation of the aforementioned postulation that the action in Geijerstam's short story unfolds between two opposite poles of reference money (or, rather, the lack thereof) and art - the narrative is launched with this dichotomy as its springboard. Melin's initial, painstaking contemplation of the last franc in his wallet is almost immediately interrupted as his «painter's eye» (Geijerstam I889: I90) takes hold of the narration, replacing the earlier despair with a delighted observation of the fugitive play of sunbeams in the greenery outside his atelier: 
Solen låg in, så att muren kastade en bjärt skugga öfver det vilda vinet, som i spalierer klängde ända upp till murens kant, och där de ljusa skotten sköto upp öfver muren, spelade solen omkring den unga grönskan och gaf den en färg, hvilken återdallrade i målarens sinne med en ton af musik. [...] han vände hufvudet för att följa solstrålarnes lek förbi den skarpa skuggan, som föll på sandgången och bort till en grupp af gula rosor, bakom hvilka syntes en af blekröda slingerrosor täckt berså. Här darrade solljuset i ett vimmel af reflexer, som kommo och gingo, alteftersom den lätta sommarvinden gungade blommor och blad. Det var en glans i de bleka bladen, som skiftade i rödt, hvitt och violett, och på marken under det hvälfda taket lekte solstrålarna mellan skugga och ljus [...]. (I90-9I, italics are mine)

The sun came in, causing the wall to throw a sharp shadow over the woodbine creeping along the trellis all the way up to the edge of the wall; and where the bright sprouts emerged from behind the wall the sun was playing in the pristine greenery, giving it a colour that reverberated in the painter's mind with a musical tone. [...] he turned his head to follow the play of sunbeams exceeding the clear-cut shadow, which fell on the sandy alley, directed at a host of yellow roses behind which an arbour covered with pale red climbing roses emerged. Here, the sunlight was trembling in a myriad of to-and-fro reflections as the light summer breeze swung flowers and leaves. The pale leaves glowed in red, white and violet, and on the ground beneath the arched ceiling the sunbeams played between shadow and light [...].

This far into the narration, nothing has given away Melin's identity as an impressionist but, as the eyes of the painter-beholder start giving prominence to the dynamic interplay between light and shadow in the passage quoted above, we get a preview of the essence of his artistic sensibility: the rays of sunshine conduct his eyes, which register the effects of moving, shifting, reflecting light, towards the foliage. The abstracting tendency of the impressionists to make items dissolve in strong light is not driven to extremes as the spectator proves able to identify botanical species; even so, the semantic field of lexical items referring to flutter and vibrancy (emphasized through the italics) indicate a heightened awareness of ever-moving light: the throbbing, dappled sunshine and the blurring play of reflections depicted in the passage quoted above show clear affinities with the attention that the impressionists painters devoted to these aspects in their rendering of light in motion. Forgetful of his hunger and sufferings, Ivar Melin then brings his easel outdoors to retain the impression of the scene. 
The narrative composition in Utan pängar is, to a great extent, symmetrical. When the opening scene repeats itself the following morning - with the difference that Melin now is left with nothing but a five-centime coin in his pocket - the atmosphere thickens: «när han stod framför fönstret med kopparmyntet i hand, såg han själf, hur måleriskt solstrimmorna föllo öfver denna tafla, där han och myntet bildade medelpunkten. - Vore jag af den gamla skolan, tänkte han, skulle jag måla en genre» (2I2; «as he stood by the window with the copper coin in his hand, it was evident to him how pictorially the rays of sunlight struck the painting of which he and the coin formed the centrepiece. - Were I of the old school, he thought, I would paint a genre»). The genre scene Melin imagines - an interior with a young painter standing, last sou in hand, by a windowsill where a revolver with its gleaming barrel is lying - is quickly dismissed as «sentimental nonsense» (213): the point at issue here is that genre painting and the art of hunger, unlike the accurate observation of fugitive effects of light on surfaces, no longer are subjects of interest to the modern artist.

\subsubsection{A literary approach to impressionist subjects}

As observed above, Melin's pictorial approach to reality stimulates his artistic inspiration and invigorates the protagonist's belief in his distinctive creative act in times when starvation and the public's inability to understand modern art seem to threaten his integrity as an artist. The text explicitly states that it is the continental light and joie de vivre that has made Melin a painter and guided him in his choice of subjects: «Det var sol, ljus, stilla, leende lycka, söderns fulla glädje [...] som lockade och drog honom att måla på en duk» (I9I; «Sunshine, light, beaming happiness, the bursting southern joy [...] had enticed and attracted him to paint on a canvas»). This bright atmosphere is in stark opposition to the dull Swedish landscape with its muddy colours emerging in front of his inner eye as he starts fearing that he will have to retreat from Paris because of the constant lack of money:

Han såg plötsligt klart som i en vision ett parti af en grå klippkust, mot hvilken de salta böljorna slogo gröna och skummiga, Det stod en brygga rätt ut i sjön, och under dess fasta plankor bullrade vågorna. Öfver en backe, beväxt med enbuskar och ljung, gick en sandig väg, och på andra sidan backen lågo ett par stora byggnader med uthus, stall och ladugård, som han kände igen. När han kommit hem från utlandet på besök, brukade han altid på moderns fråga svara, att han aldrig hade sett något vackrare. (2OI-O2) 
All of a sudden he saw clearly, as in a vision, a stretch of grey, rocky coastline hit by salty waves, green and foamy. There was a pier leading straight out into the sea, and underneath its firm planks the surfs thundered. A sandy path led across a hill where juniper and heather grew, and on the other side of the hill rose a few large buildings with an outhouse, stables, and a cowshed that he recognized. Every time he came home to visit from abroad, he would always reply to his mother's question that he had never seen anything more beautiful.

The dark tonalities of the scene and the total absence of natural light, so different from the scenery that has inspired the artist's «osålda dukar med ljusa, klara färger» (202; «unsold canvasses in light, dazzling colours»), as well as the eerie detail of the pier luring the beholder out into the wild sea, leave no doubt as to the nature of Melin's yielding to his mother's national-romantic sentiment: his accommodating answer must be read as blasé, if not ironic. All the more striking is the contrast between these two worlds when the image of the Swedish landscape reappears for the second time in the narration: this time, if the analogy holds, Melin's vision of an obscure old woman in a straw hat, on top of a hill and against a backdrop of blue skies and white clouds, seems to turn into a vrångbild (a distorted double) of one of Monet's favoured subjects, that of a young woman wearing a white dress and a veiled hat, silhouetted against a summer sky (fig. II): «på krönet af kullen, omgifven af ljungen, klart aftecknande sig mot den blåa himlen, på hvilken de hvita molnen seglade för hafsvinden, såg han en kvinna i mörk klädning och en stor halmhatt öfver det gamla ansigtet» (202; «on top of the hill, surrounded by heather, sharply silhouetted against the blue sky where white clouds were sailing in the sea breeze, he saw a woman in a dark dress and a large straw hat over her old face») 7 .

The need to advance hypotheses for identifying painterly equivalences to Geijerstam's descriptions in Utan pängar might not be of vital importance for the understanding of the story although, given the phenotype of the painter-protagonist, impressionist correspondences to Ivar Melin's «unframed paintings» should not be considered far-fetched. Even though this second category of narrative units does not strictly read as literary pictorialism, at least not in Hagstrum's articulate understanding of the term (Hagstrum I958), the text makes it clear that these scenes filter into Melin's mind through a pictorial screen. The metaphor of «unframed paintings», utilized to present the urban scenes unfolding in front of the impressionist's eyes does not, however, prevent that these units are less pictorial than

7 In these textual features of Geijerstam's tale one easily recognizes traits familiar to the artist-novel as a genre. Maurice Beebe (I964: 22) mentions the «dissatisfaction with the domestic environment, estrangement from a philistine father [...] the discovery that you can't go home again» as archetypical topoi of this tradition. 
the portrayal of light commented on earlier. Here, Geijerstam is not concerned with demonstrating Ivar Melin's sensitivity to composition and light effects, if not marginally. Still, although pictorial markers are absent from these descriptions, what the painter chooses to see during his city walks summarizes the repertoire of the impressionists' urban subjects: the leisure activities of the bourgeoisie in the city parks (206); the drinking and lingering at cafés and the strolling in the streets (237-39); the night views overlooking crowded boulevards illuminated by electricity (24I-42).

To conclude the investigation of what we have called Geijerstam's 'literary' approach to impressionist subjects, we will take a quick look at two examples of urban scenes mentally 'framed' by the protagonist, namely the Luxembourg Gardens and the Haussmannian boulevard at night, which share their motifs with well-known impressionist canvasses:

På vägen hem hade han kommit in i Luxembourgträdgården, och han hade stannat i den långa allén, och såg på den myllrande skaran af barn, som, åtföljda af sköterskor eller mödrar, lekte under de skuggiga träden. De ljusklädda småttingarna med sina korta strumpor och bara ben sprungo, sutto och lågo om hvarandra, och utan den ringaste antipati för modet, var det hans vana att stå här och betrakta dessa olika fantasidrägter, som gjorde sig så bra i den starka dagern, och barnens lifliga ansigten, som njöto af sommaren i denna stora park, hvilken är det sydliga Paris' lekstuga. (206)

On his way home he entered the Luxembourg Gardens, and he stopped in the long alley to watch the swarming crowd of children playing under the shady trees, accompanied by nannies or mothers. Dressed in light colours with short stockings and bare legs, the little ones were running, sitting or lying pell-mell; and with no antipathy whatsoever for fashion, he had taken to standing there and looking at the fanciful garments that came forth so nicely in the strong light, and the lively faces of children enjoying summer in this great park, which is the playhouse of southern Paris.

The image of well-dressed children playing in the shade of the trees in this urban park, chaperoned by nannies or mothers, finds confirmation in canvasses painted a few years earlier by August Renoir (1883) and Albert Edelfelt (I887, fig. I2). Edelfelt's painting I Luxembourg-trädgården i Paris (In the Luxembourg Gardens in Paris) is considered the culmination of impressionism in this Finnish artist ${ }^{8}$.

8 Albert Edelfelt (1854-1905) was the first Finnish artist to gain international fame. After 
As to the second example, Geijerstam's nocturnal scene dwelling on the dark blue night sky, the glimmering stars and the effects of the electric street lights on the wide boulevard teeming with life, captures a motif similarly represented by Camille Pissarro in the painting Boulevard Montmartre: La nuit (The Boulevard Montmartre at Night, fig. I3), owned by London's National Gallery':

Hans hufvud var klart och redigt, han såg hur den djupblå aftonhimmelen med tindrande stjärnor hvälfvde sig öfver honom, längs efter boulevarden glänste lyktorna med sitt matta sken, och öfver Place de la Concorde, öfver Madeleine-kyrkan, längs utmed hela den breda boulevarden, som böljade af åkande och gående, glänste de elektriska glödlampornas hvita, dalrande skimmer. (24I-42)

His mind was clear and lucid, he saw the dark blue night sky with twinkling stars arching above him. Along the boulevard the street lights shone opaquely, and above Place de la Concorde, above the Madeleine Church, all along the broad boulevard bustling with carriages and pedestrians, the electric light bulbs' white, flickering gleam glistened.

Correspondences between Geijerstam's text and Pissarro's painting are found in the framing of the recent Parisian boulevard by night with its artificial illumination, a modern subject that also resonated with Edvard Munch's sensibility while passing by La Madeleine during a night ride through Paris in I89 I, as testified to in his diary ${ }^{\mathrm{I}}$.

We may not have the elements necessary to consider single impressionist canvasses as sources of inspiration to Geijerstam's textual images, but drawing on the writer's attention to the above-mentioned variety of urban Paris, we can,

studies in Finland and in Belgium, he moved to Paris in I874. Famous for his historical subjects, Edelfelt came into contact with the impressionists through their exhibitions at DurandRuel's studio and commented on their art in the Finnish press. In spite of his initial biting comments he was later influenced by their art, as I Luxembourg-trädgården $i$ Paris reveals, cf., e.g., Reitala (I997) at https://kansallisbiografia.fi/english/person/32I7: «The years I88687 saw the production of the large painting of the Paris Luxembourgin puisto (Luxembourg Gardens). In exhibitions held at Georges Petit's gallery, Edelfelt had begun collaborating with leading French impressionists, a fact visible in this work. Light was an ever more important element; but at the same time there was no compromising over the detailed nature of his work. In his sketches and small works from the I88os there are many features reminiscent of the impressionists». Accessed 25 January 2014.

9 Though undated, Pissarro's work is part of his 1897 series of paintings dedicated to the rendition of this boulevard at different times of day. It was not exhibited during the artist's lifetime. Cf., http://www.nationalgallery.org.uk/paintings/camille-pissarro-the-boulevard-montmartre-at-night. Accessed 25 January 2018.

Io Cf., Storskog 2003: I9I. 
however, resolve that with Utan pängar the 'iconic lexicon' (Lund I982: 6I-64, II9-I2I) of impressionism is assimilated into the Swedish prose of the same epoch and its subjects considered relevant for an art concerned with modernity.

\title{
2.1.3. The decorative use of the visual arts in literary prose
}

In her approach to the ways in which prose writers use the visual arts, the American scholar Marianna Torgovnick explains the modern novel's diverse engagements with art as a «continuum» accommodating «different degrees of involvement» (I985: I3-I4). The least intense textual use of elements belonging to the domain of the visual arts is referred to as «decorative» on Torgovnick's scale, as explained in the following passage:

\begin{abstract}
When small and isolatable units of the novel - like allusion, description, or metaphor - show a definite, definable use of the visual arts, I will call this a decorative use. I will also use the term decorative when characters in novels are painters or sculptors but their vocation has virtually no consequence or felt influence in the novel. [...] Both quantitatively and in terms of significance, the decorative use of the visual arts constitutes the smallest degree of involvement I will discuss. It sends us to another discipline, but not for long. It asks us to think about the visual arts, but not too hard (I7, italics in the original).
\end{abstract}

The 'decorative mode' is then of limited value in making sense of a literary text (Torgovnick I885: I04). While the title of Geijerstam's text, Utan pängar, gives reasons for the inclusion of the tale in a collection of short stories entitled Fattigt folk, which sees as its encompassing theme the naturalistic observation of the hardship of the lower classes, the narrative units discussed above mainly help to underscore the painter's aesthetical orientation. They anchor the painter to the impressionist age: a connection that would be much weaker, perhaps even lost to the eye of the reader, were they to be removed. As I see it, Geijerstam's references to the alliance between Melin's picture-seeking eye and light effects, on the one hand, and to the subjects that populate impressionist works of art, on the other, combine to tell the story not of any starving avant-garde painter but of the starving impressionist painter, an argument which is of interest to my discussion here, but might be considered irrelevant to the short story as a whole and to its context of publication. A discussion of the aesthetics and techniques of impressionist art that allows us to advance to a higher degree of involvement in Torgovnick's continuum, is instead introduced through the ekphrastic presentation of Melin's own painting in the text. Let us see how. 


\subsubsection{Overt references to works of art: the ekphrastic discourse}

That the impressionist painter should make his debut in Swedish prose through Geijerstam's only contribution to the genre of artist fiction (Svensson I985: 224) is interesting in relation to the author's performance as a literary critic. As I have been able to demonstrate, Geijerstam was among the very few critics writing in Swedish to prove aware of 'literary impressionism' as a term. As previously observed, Geijerstam first resorted to this expression in I884 (a year, which according to local standards must be considered early in the history of literary impressionism as a critical province, since the expression seems to have appeared in a Scandinavian context only in I883, through the use the Norwegian critic Henrik Jæger made of it, as discussed earlier in the present work $)^{\text {II }}$. In summary, and as we have seen, Geijerstam defined Georg Nordensvan's narrative mode in Skuggspel as an example of literary impressionism (Geijerstam I884), and two years later he again applied the term when reviewing the second part of Strindberg's autobiographical novel Jäsningstid (Geijerstam I886). These writings, as pointed out earlier, show that to Geijerstam literary impressionism was a question of finding a verbal counterpart to the technique of the impressionist painters, a form of writing synonymous with a metonymic mode of description and with the idea of the 'innocent eye'. Although Geijerstam's own literary output does not offer examples of personal attempts at literary impressionism as intermedial transposition, an analysis of the ekphrastic description dedicated to Melin's landscape painting in Utan pängar will, however, confirm Geijerstam's ability to grasp the essence of that painterly impressionism, which he considered convertible into words.

Next to the general, unspecific, observations on Ivar Melin's art - according to which he is an avant-garde author of oeuvres that «altid chokerade och stälde honom på kant med världen, aldeles som om han varit en agitator för nya och våldsamma läror» (I93; «always shocked and opened up a conflict between him and the world, just as if he were an agitator for new and violent schools of thought») and cause him «ett lif af umbäranden» (I93; «a life of hardship») - the text presents one case of ekphrastic description dedicated to the artist's own canvas. This half-finished painting, described through the perspective of Melin, represents a study of a cornfield where the flowers appear as nothing but coloured dots, and the trees in the background are «omtöcknade af den lätta blåa slöja, som hvilar öfver det franska landskapets lointainer» (2I4; «surrounded by the airy blue veil that stretches out over the distant voids in French landscapes»). The insertion of an ekphrastic discourse at this point of the short story supports the hitherto feeble technical and aesthetic discussion of impressionism, and emphasizes the controversial, though unstable, situation of the painter Melin. The

II Cf., Lund I993: 48, and p. 6I-62 in this study. 
unfinished painting is, in fact, a detail accentuating Melin's position at the crossroads of tradition and modernist regeneration.

In an inner monologue (205-06), Melin has made it clear to the reader that he is not a full-fledged modernist but a neophyte striving to master the latest novelties in art, rather confident that his technical ability would win him a medal at the official Salon should he wish to submit a traditional work (22I). His reflections on what to do with the cornfield study - finish it according to the dictums of the arbiters of taste (25I: «en okunnig hop»; «an ignorant lot») or conserve its sketchiness, the dots and the dashes that remain true to his own impression of the scene - mirror the lack of self-confidence that assaults the famished Melin. As Melin offers the reader a sample of the criticism he expects from the public, Geijerstam pinpoints some of the key characteristics of painterly impressionism:
jag undrar just, hvad folk skulle säga! Först och främst skulle de säga, att något så där blått fins inte i naturen. Ja, det är klart. Alla människor vet, hvad som fins i naturen, utom den, som försöker att måla den. Sedan skulle de undra, hvad de där prickarna skul- le betyda. Blommor ser inte ut som prickar, skulle de säga. (2I4)

\begin{abstract}
just imagine what people would say! First and foremost they would say that there is no such blue in nature. Well, of course. Everyone knows what nature looks like, except the one who wishes to paint it. Then they would ask themselves what those dots are supposed to mean. Flowers do not look like dots, they would say.
\end{abstract}

Geijerstam is here alluding to the impressionists' blue shadows «that caused great excitement among visitors at exhibitions» (Itten I970: 8I); to the idea of the innocent eye with its reliance on pure observation, independent of mental preconceptions, in the approach to the painterly subject; and to the abstracting dots and dashes achieved through short brushstrokes. As Melin very well knows, to please the public he would just have to paint «lite tydligare [...] t. ex. måla ut blombladen [...] ta bort det blåa omkring popplarna och utföra dem, som det heter, så att man kunde räkna löfven på en half mil» (2I5; «a little bit more in detail [...] e.g., paint the petals on the flowers [...] remove the blue colour around the poplars and execute them, as they say, so that one could count the leaves at half a mile's distance»).

This ekphrastic passage is undoubtedly the textual segment that draws closest to the detection of an aesthetic discourse on impressionism in Utan pängar. Enraged at the thought of having to renounce his artistic credo, Melin lashes out against his unfinished canvas as a Swedish art merchant with money in his pocket enters the atelier. In the ensuing conversation 
with the profiteering art dealer, impressionism is only vaguely mentioned (222), but it is significant that this coarse character should not find anything worth buying among the «ljusa stycken» (Ibidem; «luminous pieces»), «extravaganta försök i en smak, hvilken han inte begrep, förrän det almänna erkännandet satt sin prägel på det» (224-25; «extravagant efforts in a taste that he would not understand before the general opinion had sieved it»), covering the walls of Melin's studio.

If Johnson assumes that «an impressionist painter, either real or fictive, often serves as foil for the author's ideas on impressionism» (Johnson I973: 287), and if Beebe claims that even a fictional portrait of an artist «helps us to understand the novelist who wrote it» (Beebe I964: 4), whether Utan pängar rather expresses Geijerstam's empathy for the impressionists or his sympathy for their adversaries might be left unsaid. More relevant than sympathies and antipathies is however the author's understanding of the essence of painterly - and literary - impressionism that we have been able to prove through the examination of his prose and his literary criticism.

\subsection{MATHILDA ROOS: FAMILJEN VERLE. EN SKILDRING}

The development in Geijerstam's tale discussed above follows a pattern that appears frequent in artist novels of different eras. Maurice Beebe has explained this narrative model as the hero's rejection of «the claims of love and life, of God, home, and country, until nothing is left but his true self and his consecration as artist» (Beebe ig64: 6). By contrast, in the novel Familjen Verle. En skildring, Mathilda Roos tells the story of a woman whose quest for self through art is almost coincidental, interrupted, and subsequently, as it seems, substituted with a commercial activity as a shopkeeper. Of interest to the present discussion is the circumstance that the protagonist's path crosses that of two uncommitted impressionists, a detail adding data to our investigation of the image of the impressionist painter conveyed in Swedish prose.

Sigrid Verle is the eldest of three sisters each of whom possesses distinctive qualities: Etty, the youngest, is witty, sociable, and graceful, Anna is neat and given to religious contemplation, Siri, who has never had any sentimental affairs, belongs to the category of fictional artists who, in the words of Beebe (I964: I6), compensate through art for their «inability to participate actively in society or to lead a satisfying passionate life»:

Ibland fylldes hela hennes inre af bittra, upproriska tankar, verksamhetslusten sjöd inom henne, hon kände en ungdomlig kraft i sina lemmar och i sin hjärna, hon ville arbeta, uträtta något; men hvad kunde hon göra, till hvad duger i allmänhet en kvinna 
annat än att älska och gifta sig? Men hvarför skulle då icke ho n älska och gifta sig? Ännu hade hon aldrig sett någon man ägna henne en skymt af kärlek. ( 96 , emphasis in the original)

At times her soul was filled with bitter, revolutionary thoughts, the will to work simmered within her, she felt a juvenile strength in her limbs and in her brain, she wanted to work, accomplish something, but what was she able to do, what is a woman commonly fit for, except love and marriage? But why would $\mathrm{s}$ h e not love and marry? Until now she had never seen any man dedicate the slightest hint of love to her.

Rather than as a calling, art enters her life as a compensation for the lack of a fiancé and to fill the emptiness she experiences. To her, painting is equivalent to any other uncommon occupation, be it journalism or the setting up of a singular commercial activity:

I detta svårmod, som endast tidtals skingrades, började småningom uppstå en mängd fantasier och planer för framtiden. Om hon icke, som Anna, blefve förlofvad [...] hvarför skulle hon då inte skaffa sig någon sysselsättning? Hon tänkte hit och dit; hon funderade på att bli lärarinna eller telegrafist, eller gå in i posten, men intet af allt detta tilltalade henne. Nej, hon ville göra något ovanligt - obestämda planer, såsom att bli artist, skrifva i tidningar eller anordna en byrå för tjänstsökande [...]. (97)

In the midst of this spleen, which only at times subsided, little by little a host of fantasies and plans for the future appeared. Would she not, like Anna, get engaged [...] then why shouldn't she get an occupation? She let her thoughts wander, she considered becoming a schoolmistress or a telegraphist, or working at the post office, but nothing seemed to appeal to her. No, she wished for something uncommon - undefined plans, like becoming an artist, writing for newspapers, or setting up an agency for the unemployed [...].

After a year of decorating crockery and interiors, Sigrid manages to convince her father to sponsor her first art lessons and then art studies in Paris. During her two years in the French capital she falls in with a group of Swedish artists who act as her guides and counsellors, subsequently introduced to her family as nothing less than «full-blooded impressionists» (II8).

Rather far into the narration, which alternately deals with the destinies of all three girls, the discourse on impressionism is introduced at the point of 
Sigrid's return from Paris in the company of her fellow painters. The presence of these impressionists in the text draws the reader into a subplot in which the old school of naturalistic depiction of the common people in rural settings, exemplified by Siri's own art, is countered by the modern-day impressionist taste, represented by her advisers, Harry Wijkler and Gustaf Larsson. The narrator's contemptuous treatment of these two impressionist disciples reveals a less romanticized and idealized impressionist character than the self-sacrificing artist figuring in Geijerstam's short story. Conny Svensson comments as follows on Wijkler's and Larsson's appearance in the text:

\begin{abstract}
Att artister - åtminstone de unga och oppositionella - är moraliskt suspekta personer betonas starkt i romanen. Förhållandet exemplifieras ytterligare av de två manliga kolleger till Sigrid, som införs i handlingen. De presenteras uttryckligen som "fullblodsimpressionister" och "opponenter" [...], varför inget tvivel kan råda vilken fålla de hör hemma i. (1985: 253)

That artists - at least the young and the noncompliant - are morally suspect characters, is something the novel strongly emphasizes. This association is further exemplified by Sigrid's two male colleagues, who are introduced into the plot. They are unambiguously presented as "full-blooded impressionists" and "opponents" [...], leaving no doubt as to what league they are in.
\end{abstract}

Svensson's incisive deduction that «dessa två män - en festprisse och en cyniker - får [...] spela rollen av typiska representanter för den unga konsten» (254; «these two men - a night reveller and a cynic - are placed in the role of emblematic ambassadors for the young art») proves quite correct as we proceed to the examination of their portrayal in the novel.

\title{
2.2.1. «Full-blooded impressionists»
}

When the two impressionists are announced in the text, the narrator gives the word to the young painter-protagonist: «Sedan presenterade Sigrid två af sina manliga kamrater bland konstnärerna, artisterna Gustaf Larsson och Harry Wijkler, ‘fullblodsimpressionister', som Sigrid sade, och ifriga anhängare af den franska målarekonsten, opponenter, m. m. i samma stil» (ıI8; «Sigrid then introduced two of her male companions among the painters, the artists Gustaf Larsson and Harry Wijkler, 'full-blooded impressionists', in Sigrid's words, and keen followers of French painting, opponents and others of the same kind»). Her definition essentially reveals less about the two artists' true character than about her own naiveté, and the authorial 
quotation marks framing the expression «fullblodsimpressionister» reveal a certain dose of irony already pointing to the unflattering portrait to be outlined shortly. These young and bold artists bring joyfulness and laughter to the home of the Verles, so much so that even pious Anna, prone to melancholia, is enthralled by the new 'continental' atmosphere: «Men... hvad var då det där ordet "lifsglädje”, om hvilket hon så ofta hörde dem tala? Var det synd däri? Hennes tankar kretsade några ögonblick kring detta mystiska ord, som alltid varit henne så främmande och ändå så skönt och lockande» (I24-25; «But... what kind of expression was that "joie de vivre", of which they so often spoke? Did it have anything to do with sin? Her thoughts lingered for a few instants on these mysterious words, which, to her, had always seemed so foreign but still so sweet and tempting»). We learn (II920) that the Verles have 'audacious' conversations revolving around art with the young painters during their cheerful soirées, although the arguments up for discussion are not once revealed.

Mathilda Roos's young impressionists are thus foremost associated with worldly pleasures. Harry Wijkler, in particular, is a socialite who subordinates art to life, and as Siri urges him to pick up his work, lest he ruin his career, he readily states in response: «Imorgon reser jag till landet och tar studier till ett vinterlandskap, i 20 graders kyla, alldeles bestämdt» (I27; «Tomorrow I am leaving for the countryside to do some sketches for a winter landscape, in minus 20 degrees, that is for sure»). At first sight, his answer is indeed that of a purebred impressionist, stubbornly faithful to the principles of plein air painting, come what may, but this denotation is deformed into a caricature as the following lines make clear that Harry enjoys the company of the admiring ladies so much that his easel remains indoors until spring arrives.

In summer Sigrid, too, takes up sketching in the open air: «Sigrid satt i solgasset och tog studier, tills hennes näsa och händer blefvo rödbruna» (I28; «Sigrid sat outside in the scorching sun, sketching until her nose and hands took on a reddish brown colour»). Even so, the subject chosen for her painting, as well as the narrator's indication that Sigrid finishes her work in the atelier as autumn arrives, reveal her belonging to the old school:

Då familjen flyttat in från landet, började Sigrid med nyvaknad arbetslust att måla på den tafla, till hvilken hon under sommaren tagit studier, och som hon ville ha färdig att exponera på nyåret. [...] Den tafla, hon höll på att måla, föreställde två små bondbarn, en gosse och en flicka, de fulaste hon kunnat leta ut, hvilka sutto på en trappa och åto smörgås. (I47)

After the family had moved back into town, Sigrid took to working with renewed stamina on the painting for which she had been 
sketching during summer, as she wanted it ready to be exhibited on New Year's Eve. [...] The canvas on which she was working represented two little peasant children, a boy and a girl, the ugliest ones she had been able to find, sitting on a step eating sandwiches.

While the other family members are incapable of understanding her selection of models - the ugliness! - the two impressionists seem, if possible, even less happy with the subject adopted. Sigrid herself, though, is content with the finished painting:

Slutligen, i januari, var taflan färdig och exponerades då, jämte andra nyheter, i Blanch's salong. Sigrid hade stora förhoppningar, de bägge barnen voro så fula som möjligt, med linhår, uppnäsa och små, ljusblå, rödkantade ögon. Hon tyckte själv att taflan var både karaktäristisk, stämningsfull och framför allt af äkta svensk lokalfärg. (I49)

Finally, in January, the painting was ready and on display, together with other novelties, in Blanch's salon. Sigrid's expectations were great, both toddlers were as ugly as possible, with fair hair, snub noses, and small, light blue, red-rimmed eyes. To her, the painting possessed both character and atmosphere and, above all, true Swedish local colour.

Unluckily, precisely those aspects of the canvas that Sigrid sees as its assets are scorned by the critics reviewing the exhibition. But it is not until Siri asks Gustaf Larsson for his opinion that she is willing to realize that she lacks the talent required of a true artist. Embedded in Larsson's scorching criticism is not only an accusation of having taken a divine occupation much too light-heartedly, but the impressionist is also addressing an attack against women artists who are vain enough to look for fame and glory through art instead of excelling at mending stockings:

det är det olyckliga med kvinnorna att, då de ingenting ha att göra, då de inte ha någon "lifsgärning", som det heter, då gripa de tag i konsten som en räddningsplanka... konsten, konsten, som mera än allt annat fordrar kallelse... och så växer det som svampar omkring oss målarinnor och sångerskor och författarinnor... aktningsvärda, naturligtvis... och redbara... men tråkiga och medelmåttiga och lika hvarandra, så att man kan gå vilse ibland dem! Och hvad är det som drifver dem härtill? Fåfänga, fåfänga! Man blir mera bemärkt, då man målar en tafla medelmåttigt än då man stoppar ett par strumpor bra! Men det häm- 
nar sig, konsten, som de profanerat, hämnar sig och ger dem ett bakslag, så att de tumla ner från sin inbillade höjd. (I55)

the sad thing with women is that when they have no occupation, no "goal in life", so to say, they clutch at art as a last resort... art, art, which more than anything requires vocation... this is why we see female painters and singers and writers sprouting like mushrooms around us... worthy of respect, of course... and honest... but boring and mediocre and akin to one another to the point that one gets lost among them! And what is pushing them? Vanity, vanity! One gets more attention when painting a mediocre canvas than when mending a pair of stockings carefully! But revenge will come, art, which they have profaned, will strike back and have them tumble down from their illusory height.

It is certainly something of a paradox that an artist representing the most modern school of painting should prove to be a conservative male chauvinist. Moreover, the thesis that a painter's occupation is holy cannot help but sound hollow coming from one of the two dispassionate impressionists in the book. Larsson's monologue, however, takes us back to the dichotomy between art and life raised by Sigrid herself at the beginning of the novel: following the conversation with Larsson, Sigrid abandons painting and sets up a stationery shop after the death of her father. Her active participation in society has made her even-tempered and content, and certain of the fact that «hon uträttade något gott och nyttigt $i$ världen» (284; «she did something good and useful in this world»). At the end of the novel the reader further learns that the other female painter in the group, the gifted Elma Bernstedt, has also given up her career after marrying: «hon målade taflor åt sin man och för att pryda hemmet, men lillan och hushållsbestyren togo så mycken tid, att hon ej hann utföra något större arbete» (28I; «she painted canvasses for her husband and to decorate her home, but the child and the household chores were so time-consuming that she did not have the time to complete any greater oeuvre»).

In summary, the two characters here associated with the art of the impressionists are thus respectively made to appear as an almost comic fraud and an arrogant bigot, the latter convinced that a woman should not aspire to anything higher than what "nature" has intended for her (I57). When Gustaf Larsson reappears in the novel's last pages, he and Sigrid are back on friendly terms. Having found a place in society, Sigrid no longer represents a threat to the holy world of art, and instead Larsson now vents his anger at the illusions of religion, by accusing the devout Anna of gullibility because of her capacity to find happiness in life. 


\subsubsection{The opposition between life and art}

Although the artistic discourse in Mathilda Roos's novel is rather shallow and but one of many narrative threads explored, nuances in the portrayal of the two 'full-blooded impressionists' contribute, in two different ways, to developing the theme of the opposition between life and art common to the tradition of the art novel. While the portrait of Harry Wijkler is one of a hoaxer, who reveals himself to be a greater lover of life than of art unwilling, as he is, to sacrifice comfort and the company of ladies for his mission, Gustaf Larsson's discourse on the illusion of finding happiness in life stresses, on the other hand, the unbridgeable antagonism between the superior ideal of art and the trite reality, to which the true artist refuses to adapt. Herbert Marcuse, who dedicated a chapter of his book to this motif, spoke of «die schmerzliche Gegensätzlichkeit von Kunst und Leben [...] [das] Wissen, daß man niemals reiner Künstler und reiner Mensch zugleich sein kann, daß einfaches menschliches Glück nur dem zuteil wird, der dem Künstlertum nicht verfallen ist» (273; «the painful antinomy between art and life [...] the knowledge that one cannot be both a pure artist and a pure human being at one and the same time, [...] that plain human happiness can only befall those who have not been surrendered to the artist's condition»).

As I see it, through Wijkler and Larsson, Mathilda Roos attempted to show two modern artists representing, on the one hand, the shallow bon vivant using his position to impress the ladies and, on the other, the conservative romantic, radical only in his views on art as a superior sphere. That the modern school of painting of which they are said to be representatives should identify with impressionism certainly indicates a lack of appreciation of this art, perhaps surprising when coming from an otherwise progressive author like Mathilda Roos $^{12}$.

\subsection{GEORG NORDENSVAN: AJA}

Other types of conflicts are at the heart of Georg Nordensvan's novella. Here, the story is told in the first person by an intradiegetic narrator who plays the part of a detached observer of events that start unrolling at a social gathering in Stockholm where the reader is introduced to the three painter-protagonists: Aja Borgström, Edvard Asp, and Sven Richert. As the anonymous narrator observes Aja standing between the two male artists, something of the ancient conflict that years earlier determined the Parisian life of the threesome comes to life. The narrator mentions «en liten konflikt som

I2 As a novelist Mathilda Roos (I852-1908) dealt with the conditions of women through themes such as female eroticism, homosexuality, and sexual abuse. She is also the author of three political pamphlets expressing concern over Ellen Key's anti-feminism. Cf., e.g., Lotass's biographical note at https://litteraturbanken.se/forfattare/RoosM. Accessed 25 January 2018. 
kunde ha utvecklat sig till en hel roman» (37, italics in the original; «a lesser conflict that could have developed into a whole novel») thus engaging in a dialogue with the title chosen for Nordensvan's collection as a whole, Tre små romaner (Three Little Novels) ${ }^{13}$. Moreover, the narrator's comment also signals that thematic concentration is on the motif of controversy.

Real or imagined, conflict and rivalry between two artists belong, as Kris and Kurtz have observed (I979: I20-25), to the most frequently recurring topoi in the literary tradition dedicated to writing the life of an artist. In the case of Nordensvan's tale, this metanarrative comment reveals that the archetypical antagonism between artists is at the core of the story. The rivalry at stake is both a matter of opposite positions in the art world and of a sentimental kind but, although it is the latter conflict that ends up governing the narration, what interests us here is the way in which the two painters' attitude to art differ: while Richert is the cutting-edge artist, always one step ahead, Asp is unsuccessfully trying to free himself from the instruction received during his years in Düsseldorf, where he trained as a landscape painter $^{\mathrm{I} 4}$. At the time of the Parisian sojourn that triggers the action, both were sentimentally involved with Aja. Having thus set the basis for the tale, the narrator moves on to recollecting «historien, som kunde ha blifvit en roman» (37; «the story that could have turned into a novel»).

In the following pages, the examination of Nordensvan's short story will be undertaken in the attempt to discover in what aspects the narrative discourse is affected by the discussion of impressionist art. To this end, some of the ten devices identified by Theodor R. Bowie (I950: 5-7) as strategies commonly employed in works of fiction focussing on painters will prove particularly relevant ${ }^{15}$. Questions regarding the aesthetics and techniques

I3 Aja appeared as a feuilleton in Idun, issues 5 to I4, I894. The same year it was also included in Nordensvan's collection of short stories bearing the title Tre små romaner. A second edition of this book was published in I908. Several changes have been made in the text in its transformation from feuilleton to printed edition; some of these are relevant to our discourse and will be discussed further on. Unless otherwise specified, all quotations are taken from the I894 edition of Tre små romaner.

I4 The Düsseldorf school had a great impact on portrait and landscape painting in the mid-nineteenth century. It is associated with idealized landscapes in the national romantic style and with a love for details. See also Dusseldorf school at https://www.britannica.com/topic/ Dusseldorf-school, accessed 25 January 2018 and Painting School of Düsseldorf at http://www. kettererkunst.com/dict/painting-school-of-dusseldorf.php. Accessed 25 January 2018.

I5 Summed up, Bowie's ten devices are: (I) the description of the painter's youth and training; (2) the description of the painter's milieu (the atelier, contacts with nature or with the cityscape, circle of friends and fellow painters); (3) the rendering of the painter's conversation with other artists, models, and art dealers; (4) the rendering of discussions regarding aesthetics and techniques (through the artist's monologues or «by an author's mouthpiece»); (5) violent criticism against the official taste and the academic tradition; (6) accounts of art exhibitions; (7) the introduction of literary figures as foils to the painter; (8) the introduction of threats to the painter's artistic integrity (e.g., sentimental affairs); (9) the presence of real painters (with their actual names or in disguise, for verisimilitude or for the sake of the plot); (Io) the practice of showing the painters at work (by describing the composition of a finished work in the order it 
typical of impressionism are introduced to a greater extent than in the other texts scrutinized in this part of the present study, and are proposed to the reader both through conversations between artists and through the intervention of the anonymous painter-narrator, who uses his position to mock the opinions of the self-proclaimed experts. We will also briefly turn our attention to the description of the artist studio, another element recurring in Bowie's scheme. Although the studio might seem of limited importance in the case of such notable plein air painters as the impressionists, the characterization of Aja's atelier illustrates - better than the attempted ekphrastic discourse dedicated to one of her paintings - to what extent this woman has done away with outdated tradition and authority. In addition, in the feuilleton version published in Idun, as we will see, the short story also included the presence of a real painter, Paul Gauguin, and of a real writer, Hans Jæger, both loosely connected with the impressionist movement.

As statements and articulations of opinions recurring in the short story bear a strong resemblance to the ones expressed in Nordensvan's art criticism, we will conclude the survey of the author's involvement with impressionism by taking a closer look at the way in which these two facets of his production combine.

\subsubsection{The theoretical discourse}

The anonymous storyteller's recollection of events, triggered by the artists' gathering in Stockholm, takes the reader back in time and space to the ideal setting for presenting a theoretical discussion on the techniques and aesthetics of impressionist art. We are, in fact, transferred to an artists' colony in the Swedish countryside, where a group of landscape painters (the narrator included) has come together to work in the open air $^{16}$. The theoretical discourse is first presented by Aja and the languid artist Nisse Linder who, like Aja, has spent the spring in Paris and returned to Sweden «fullproppad med moderna teorier och hade klart för sig, både hvad som borde målas och hur allting borde målas» (Io8, italics in the original; «stuffed with modern theories and cognizant both of what was worth painting and how it should be painted»). The two companions get a chance of posing as experts as Edvard Asp, a painter whom they judge as «tunguisk» (III; «soulless»), «düsseldorfare» (Ibidem)

presumably came into being or while the artist is at work on the painting).

I6 A thorough study highlighting the dynamics at work in a Scandinavian artists' colony at the end of the century is Anna-Maria Wiljanen's doctoral dissertation «Nej, i sanning, ett bättre ställe hade den unga målaren ej kunnat hamna på». Önningeby konstnärskoloni och de mångfacetterade sociala nätverkens interaktion (Wiljanen 20I4; «No, Truth Be Told, the Young Painter Could Not Have Ended Up in a Better Place». The Artists' Colony of Önningeby and the Interaction of the Multifaceted Social Networks). Wiljanen has a chapter on the of role women of this colony established on the Åland islands under the leadership of Victor Westerholm in the years I886-92 (2014: I45-80). 
and, tongue-in-cheek, «skicklig» (Ibidem; «skilled»), pays a visit to the colony.

When referring Linder's and Aja's lesson on the latest trends in painting, the narrator gets his chance at acting as a superior and somewhat caustic connoisseur, dismissing both Linder's and Aja's knowledge of modern art as superficial:

den store teoretikern Nisse [...] laddade ur sig den nyaste visdom, han fört med sig från Paris ${ }^{17}$. Aja sekunderade honom ibland, men med vida mindre säkerhet. Asp hörde på dem med intresse - detta var tydligen nytt för honom. [...] Han talade om impressionister och luminister och pointillister. Till slut blef hans anförande så inveckladt och dimmigt, att Aja måste bita af det med ett skämtsamt ord. (II3-I4)

the great theoretic Nisse [...] unloaded the latest wisdom he had brought with him from Paris. Aja assisted him at times, though much less convinced. Asp listened to them with interest - this was apparently news to him. [...] He spoke of impressionists and luminists and pointillists. In the end his speech got so confused and nebulous that Aja had to cut it with a humorous word.

Less given to abstract reflection, Aja resolutely leads Asp into her studio to show him an example of the kind of art that Linder has whimsically been describing. Her own production divides into «publiktaflor» (II6; «paintings for the public») and «experimenter» (Ibidem; «experiments») ${ }^{18}$. The canvas corresponding to Linder's theoretical discourse draws close to the archetypical impressionist painting, showing a landscape captured in the evening light with a clear, bright blue, colour enveloping the trees in the backdrop. As Edvard Asp retraces his reaction to Aja's landscape painting during a conversation with the anonymous narrator, he is outraged not only at the paintress's cynical division of art into two categories, but also at her use of this blue colour:

i hennes studier är det något groft och rått - till exempel den där stora blåa, det är ju blå färg struken öfver allt, i stället för att

I7 In the feuilleton version of the short story, the irony with which the narrator treats Linder's 'expertise' is even more evident. The phrase which at this point stresses his ironic stance and reveals the narrator's superiority has been left out in the short story collection: «Hur pass djupt han trängt in i de moderna idéerna och hur skarpsinningt han uppfattat dem, skall jag lämna osagt» (Nordensvan $1894 \mathrm{~b}$ : «How deeply he had dwelled on the modern ideas and how profoundly he had understood them is best left unsaid»).

I8 One of Aja's «publiktaflor» seems to mimic Sigrid's unfortunate painting in Familjen Verle, previously discussed. It represents «en liten linhårig flicka ute på en äng i solgass» (II4; «a little flaxen-haired girl in a sunlit field») and is described by Aja as «en köptafla för grosshandlarherrskapet, när man flyttat in från landet på hösten» (Ibidem; «a commercial canvas for the bourgeoisie who is back in town after a summer in the countryside»). 
det skulle vara luft. Det är tillyxadt, ingenting smält, ingenting personligt. För mig är det motbjudande att se naturen uppfattad så utan känsla och kärlek. Och så att måla i en helt annan anda, när det är frågan om att måla taflor som ska' bli lätt sålda - det är cyniskt och okonstnärligt. (II7, italics in the original)

there is something rough and raw about her studies - for example that big blue; blue colour has been smeared all over where there should be air. It is roughly sketched, nothing digested, nothing personal. I am disgusted at seeing nature represented without feeling or affection. And to paint with a whole different spirit when it comes to selling - that is cynical and inartistic.

Aja's way of explaining the principles of impressionism to Asp, a painter who is holding on to his technical bravery, stresses the importance of achieving the 'total effect': «Aja nöjde sig likväl med att framhålla för honom, att målaren bör söka ljus och luft, bör bry sig kitten om naturens detaljer utan endast söka totaleffekten i motivet» (I22; «Aja was just as satisfied with emphasizing to him that a painter should look for light air without paying any attention what so ever to details, and instead strive to obtain the overall impression of the motif»). Linder, on the other hand, enters into a semiscientific discussion on the new, revolutionary colour theory by hinting at the impressionists' idea of letting colours blend optically rather than making use of tonal contrasts (123).

Asp's receptivity to their teaching is shown through his solitary contemplation of Aja's work (124, I26) and perhaps also through the plein air canvas representing the rising sun on which he is secretly working, as described by the narrator who is the first to see it (127). Even so, just as Aja suspects, during a spell of bad weather Edvard cannot resist continuing to refine his Morgonstämning (I3I; Morning atmosphere) indoors, thus losing all his promising work. As an impressionist he is doomed to failure, as is confirmed by the narrator reporting that, while in Paris, Edvard was working on «experiment, som inte alls lågo för hans lynne [...] ögonblicksstämningar [...] luftstudium» (I35; «experiments, which had nothing to do with his temperament [...] instant impressions [...] the study of air»). Accordingly, he then falls back to composing decorative landscapes indoors (I39).

\subsubsection{The artist's studio}

There is, however, another side to Aja's adoption of the impressionist idiom, hitherto unseen in the texts discussed in this part of the study. The paintress's familiarity with le dernier cri is unmistakably palpable in the collection 
of Japanese curiosities that adorn her atelier. When the reader is allowed entrance to Aja's studio, the narrator describes the milieu as «modernt "parisiskt"» (II4; «modernly "Parisian"»), decorated as it is with drapery, paper lanterns, fans, and other «godtköpspariservaror» (Ibidem; «Parisian bric-abrac»). These are elements that make of Aja an addict of the fashion of Japonisme which had spread in the European art world after the reopening of the Japanese borders in I854, showing her sympathies for an art trailing a blaze towards modernity through its foreignness to the classical tradition. There is, however, nothing in Aja's affection for Japonerie that leads us to imagine that it also has an influence on the aesthetics of composition in her own work. Her environment rather suggests the aesthetics of those impressionist artists whose canvasses feature oriental artefacts simply as props.

Another point of view on Aja's atelier is offered through the eyes of Edvard's wife. When Mrs Asp enters the studio, she takes a look around only to find Aja's attempts at bedecking her environment «med pariserchic temligen besynnerliga och smaklösa» (I894b: 56 ; «in the Parisian fashion rather bizarre and tasteless»). Aja's modernity thus represents a stumbling block in the marriage of the Asps, appearing as attractive to Edvard as it appears repugnant to his wife.

\subsubsection{The impressionist as bohémien}

Unlike Asp, Aja, and the narrator himself, Sven Richert is only seen in the company of Frenchmen and does not socialize with the Scandinavian artist colony in Paris, were it not for his association with the Norwegian anarchist Hans Jæger. In Aja, a tale, as we have seen, revolving around the divergence between painters of the juste milieu and painters of the avant-garde, the motif of conflict is further fuelled by Richert's connection with bohemians and anarchists, a detail which places him on the outskirts of society ${ }^{19}$. Richert's association with the antisocial Norwegian writer who refused to accept authority places the painter in the tradition of alienated artists caught in the act of épater le bourgeois, originating, according to Beebe (I964: 22) with prototypes such as «Cain, Lucifer, or Prometheus». The isolation of the artistic genius is thus pushed one step further than in Familjen Verle, where Gustaf

I9 In the version of the short story included in Tre sma romaner (I894a), Hans Jæger is described as the notorious author of a novel with the telling title of Decadence, whereas in the feuilleton version (I894b), Jæger is «en norsk författare, martyr (i världsåskådning) och författare till Fri Kierlighed» («a Norwegian writer, martyr [as to Weltanshauung] and author of Fri Kierlighed»). The title Fri Kierlighed (Free Love) is thinly disguising the one given to the first volume of Jæger's disreputable autobiographical trilogy, Syk kjaerlihet (Sick Love), of I893. The latter version of the short story also replaces the name of Paul Gauguin, to whose atelier Aja pays a visit in the company of Richert in the feuilleton, with «monsieur Gasque, symbolisten» (I58; «monsieur Gasque, the symbolist»). Gauguin is the only historical painter appearing under real name. 
Larsson adheres to a romantic tradition when proclaiming his being of a superior essence: the impressionist Sven Richert's association with the bohème turns instead the portrait of the artist into that of an outcast and a declassé.

If the introduction of a recognizable historical figure in the artist tale is done, according to Bowie (I950: 6), «for the sake of the plot and for the purposes of verisimilitude», the company of the Norwegian bohemian proves well-suited to a revolutionary painter like Sven Richert, who has rapidly moved on from being an impressionist «med hull och hår» (I34; «through and through»), painting «våldsamma effekttaflor» (Ibidem; «violently shocking paintings») to becoming an «intentionist and syntetist» (Ibidem; «intentionist and a synthetist»), who despises the trivial study of nature ${ }^{20}$.

Compared to the other fictional impressionists discussed above, this description of Richert's career is likely to turn him into the one artist whose fictional life is the most truthful to the late ninenteeth-century art scene in Sweden. As mentioned earlier, to most Scandinavian painters, impressionism was but a phase in their development as artists (Gunnarsson 2002: 25), and a movement often encountered in years when significant changes and novelties impeding the very access to impressionism were emerging in the art world. According to Hans Henrik Brummer (2002: 79), in the reorientation towards symbolism and «the discovery of the immaterial world»,

what manifested itself to Scandinavian artists, as for instance Axel Gallén, Richard Bergh, and Prince Eugen, was the re-emergence, and rehabilitation, of other realms, far from the Parisian boulevards. And there was another aspect. The art of Edvard Munch allowed access to a deeper dimension of human experience. (Ibidem)

Sven Richert thus remains true to his nature of «farlig upprorsmakare» («dangerous rebel») all the way through his advancement from an experimental and disparaged impressionist to his embracement of an abstruse symbolism. This characterization of Richert also sustains the fact that impressionism was still seen as a radical movement, not yet approved of by the critics, as late as the I88os, that is, in times when the true radicals among the artists had already moved on towards symbolism (cf., Hedström 2002: 74).

20 Jaeger's connection to the adjective 'impressionist' was, as we have seen, more of a political kind, not so much dependent on his adherence to impressionist aesthetics as on the idea of subversion associated to his name. Impressionism, the first movement of the modern avant-gardes, had a revolutionary concept which attracted the bohemian subculture in Norway. Virginie Pouzet-Duzer, through Isabella Checcaglini, reminds us of the fact that 'impressionist' as a definition was often synonymous with «être traité de "revolutionnair", d'“intransigeant", d'“indépendant", et aussi de "communard"» (2008: 63; «being treated as a "revolutionary", an "extremist", and also a "communist"). 


\subsubsection{Impressionism in Nordensvan's art criticism}

Both the wording and the arguments that are up for discussion in Aja can be found in Nordensvan's art criticism. When defining Sven Richert a «farlig upprorsmakare», the author, in point of fact, resorts to an expression he had used to mock the critics' reaction to the first impressionists in an article dating back to I883 (Nordensvan I883c: I7). In the following paragraphs, we will trace the change gradually occurring in Nordensvan's views on impressionism starting from I883, the year in which his article Impressionism appeared in Ny illustrerad tidskrift, up to the publication of Aja in I894, and take a look at how these assessments resonate with the understanding of impressionism in the short story.

In I883, more than ten years before the publication of Aja, Georg Nordensvan published three articles of interest to our discussion here: Impressionism (I883a), Studier i modern konst. Parisersalongen 1883, I and II (1883b); Studier i modern konst. Parisersalongen 1883, III and IV (I883c). While demonstrating that he had grasped the revolutionary achievements of the movement, awarding the French impressionists a place in art history comparable only to the that of the Romantics, Nordensvan gave a detailed account of the methods and techniques concerning impressionist landscape painting:

Det är nu länge, sedan ungdomen först började fråga, hvarför landskapsmålaren återgaf blott naturens enskildheter, prickade ut löf i stället för att måla träd och målade träd i stället för att gifva totalbilden af en skog. Så började en och annan på egen risk att fästa på duken den stämning, de hade för ögonen och som intagit dem, och för dennas skull utförde de enskildheterna mera summariskt, så som det syntes, då man plirande med ögonen kastade blott en flygtig blick ut öfver motivet. Att återgifva ej naturens alla små bisaker utan det intryck, ett landskap - smått eller stort - gaf [...] det var ett jettesteg framåt, liksom det också var det första steget mot impressionismen. (I883c: I7)

It has been long since young people first started to wonder why the landscape painters only depicted nature's minutiae, pinpointing single leaves instead of painting trees and showing trees instead of the total impression of the wood. One after the other they set out to capture on canvas the atmosphere in front of them, which had enthralled them, and so they rendered the details summarily, the way these appeared when one gives a passing glance at the motif. The idea of representing the impression of a landscape - whether minor or major - instead of depicting every single natural element $[. .$.$] was a huge step for-$ ward, just as it was the first step towards impressionism. 
However, Nordensvan underscores the gap between the moderate masters of impressionism - De Nittis and Jacquemart - and the radical impressionists, «nyhetsmakare» (I883c: I7; «noveltymakers») with «vämjeligt råa framställningssätt» (I883a: 4I9 and I883b: I8; «horribly crude rendering»), who have abandoned the tonal values and applied dots of pure colour directly onto the canvas:

\begin{abstract}
Så tog den yttersta venstern steget fullt ut, i det den började att lägga färgen rå och oblandad på duken. En tafla bör ses på ett visst afstånd för att verka med full kraft. Nå väl, hvarför då blanda sina färger på paletten till den ton, naturen möjligen har, men som på det der afståndet ej gör sig fullkomligt rätt; hvarför ej hellre sätta på taflan hvarje färg ren för sig och låta dem blanda sig i åskådarens öga, låta dem flyta samman så, att totalverkan af dem, då de ses på “det der afståndet”, blir den rigtiga? Detta är impressionisternes regel [...]. Impressionisten uppgifver helt och hållet all elegans i behandlingen, då hans tafla består ej af penseldrag utan af färgfläckar, och likaså försmår han ofta all noggrannhet i teckningen, då han sträfvar att återgifva intet annat än ögonblickets intryck. (I883c: I7)
\end{abstract}

The extreme left-wing painters then went all the way as they started to use pure, unmodulated colours on the canvas. Well, why blend the colours on the palette in an attempt to find the tone that nature might have, but which at a distance does not perfectly correspond; why not rather apply unblended colours and allow these to mix in the eye of the beholder, merge in a way that their total impression, seen at "a certain distance", proves correct? This is the impressionists' rule [...]. The impressionist perfectly renounces all elegance in treatment, as his painting is not made up of brushstrokes but of colour dots, he also disdains any accuracy in drawing, in an attempt to render nothing but the momentary impression.

Just like Edvard Asp lamented to the narrator after seeing Aja's little landscape, Nordensvan, too, warns against the tendency of the radical impressionists to fall back on certain mannerisms that risk cancelling the individuality of each artist, such as the extravagant use of the blue colour: «för att få luft i en tafla målar en allting blått, hvilket tycks mig föga bättre än att hålla taflan i grått, som andra göra nu för tiden, eller i brunt enligt münchener-receptet» (Ibidem; «to make a painting look airy one paints it all blue, which seems to me not much better than keeping it all grey, like other painters do nowadays, or brown, according to the recipe of the Munich school»), and 
remarks that few impressionist canvasses are a pleasure to the eye or an embellishment in the collector's home.

In I885, Nordensvan reviewed the so called «opponentutställningen» («the exhibition of the opponents») held in Stockholm, which saw numerous Swedish painters who had studied in Paris come together to protest against the lack of reforms in the academic art world. «Pariserskolan», especially its representative Bruno Liljefors, on which impressionism had a lasting impact (Nordensvan I885: 75, 79), is appreciated by the critic as it has proved capable of renewing Swedish landscape painting (78). Nordensvan, however, laments the impressionists' devotion to pure observation, which runs the risk of producing an art without any substance, one in which form prevails over content: «formen, utförandet, tekniken skymma bort innehållet eller öfverskyla bristen på innehåll» (75; «form, execution, technique stand in the way of content or conceal the lack of content»).

As the «left-wing» Swedish painters (Bergh, Kreuger, Georg and Hanna Pauli, Nordström, Ekström, Liljefors) mature and refine their impressionist technique, Nordensvan sees the individuality of each artist emerging out of the earlier, unspecific mannerism, so much so that he is now willing to substitute «impressionism» with «individualism» (I890: 48I). In I89I, he writes as follows about Anders Zorn's impressionist paintings:

Taflorna äro målade raskt och summariskt, med tydligt uttryckt afsikt att visa ögonblickets stämning, stundens färger med all deras friskhet, styrka och glans - med sedan ej gifva något mera, intet detaljerande, inga delikata linjer att se på nära håll, ingen elegant penselföring, det hela impressionen af motivet och ingenting mera. (I891: 397)

The execution of the paintings is hasty and summary, with the evident intention of rendering the atmosphere of the moment, the temporary colours in all their freshness, strength, and brightness - and then end it here without going further; there are no detailed, delicate outlines to scrutinize at a close distance, no elegant brushwork, it all comes down to the impression of the motif and nothing else.

Two years later it was the Norwegian painter Werenskiold's turn to be defended from his detractors' accusations, according to which his paintings were unfinished. Nordensvan now dismisses this critique as irrelevant and as one coming from critics who fail to understand that Werenskiold's technique - the rendering of vibrating light through the use of pure colour dots - is the method of a genuine impressionist and also representative of «den framåtsträvande konsten» (I892: 449; «progressive art»). 
As we draw closer to the year of Aja's composition, Nordensvan has thus come to moderate his criticism of what he earlier saw as the 'weak' aspects of impressionist art. But above and beyond any personal aesthetic preferences, the main point is again, as in Strindberg's case, that Nordensvan proved capable of understanding the novelty of this painterly technique right from the early i88os, although he considered it applicable, with caution, only to landscape painting. As he recycles, in Aja, expressions present in his art criticism to describe the impressionists in the short story, he reprocesses, in hindsight, his own early bewilderment. 


\title{
$3 \cdot$ \\ THE PHENOMENOLOGICAL IMPRESSIONIST
}

In The Stanford Encyclopedia of Philosophy phenomenology is explained as follows:

\begin{abstract}
Literally, phenomenology is the study of "phenomena": appearances of things, or things as they appear in our experience, or the ways we experience things, thus the meanings things have in our experience. Phenomenology studies conscious experience as experienced from the subjective or first person point of view. [...] In recent philosophy of mind, the term "phenomenology" is often restricted to the characterization of sensory qualities of seeing, hearing, etc.: what it is like to have sensations of various kinds. However, our experience is normally much richer in content than mere sensation. Accordingly, in the phenomenological tradition, phenomenology is given a much wider range, addressing the meaning things have in our experience, notably, the significance of objects, events, tools, the flow of time, the self, and others, as these things arise and are experienced in our "life-world". [...] In its root meaning, then, phenomenology is the study of phenomena: literally, appearances as opposed to reality. [...] Originally, in the I8th century, "phenomenology" meant the theory of appearances fundamental to empirical knowledge, especially sensory appearances. ${ }^{\mathrm{I}}$
\end{abstract}

The examination of the way in which the impressionists practiced phenomenology is the purpose of this section of the present study. As Victor

I Smith 20I3, at http://plato.stanford.edu/entries/phenomenology/. Accessed 2 February 20I8. Italics in the original. 
Carrabino tersely settles, this connection is determined by analogies in the perceptive experience: «a similarity in perception between phenomenology and Impressionism exists» (Carrabino I984: 269). As we have seen, impressionism as a perceptive experience can be said to be synonymous with a form of observation untainted by all prior knowledge concerning the subject observed, as well as by any systematic reflection and ordering of the same. According to Carrabino, this subjective vision and rendering of reality finds its counterpart in phenomenology, since impressionism «shares with phenomenology the same penchant in viewing reality not as it should be, but as it is, as it appears to the perceiver's eye, once it has been bracketed from its spatial and temporal surroundings» $\left(26_{3}\right)^{2}$. In looking at impressionism as a movement encompassing different artistic genres (the visual arts, music, and writing), Carrabino's study The French Nouveau Roman: the Ultimate Expression of Impressionism, reads literary impressionism as an ahistorical, subjective, way of relying on the senses in its expression of reality, and studies the «phenomenological novels» of Alain Robbe-Grillet, Nathalie Sarraute, and Michel Butor as the «ultimate expression» of impressionism (Ibidem).

By the same token, critics such as Sven Møller Kristensen (I955: II937), Marlies Kronegger (I984), H. Peter Stowell (I984), and John Carlos Rowe (2009: $189-218$ ), have made attempts to pinpoint the literary impressionists' phenomenological approach to the perception of reality. Møller Kristensen's chapter on fanomenologisk apperception in Impressionismen $i$ dansk prosa 1870-1900 introduces the idea of phenomenological apperception as follows:

Den passive, fænomenologiske opfattelse medfører, at det først og fremmest bliver tingenes overflade, der nedfælder sig på papiret; det flygtige, ureflekterede indtryk fanger ofte kun den fremherskende egenskab ved en ting, og i fremstillingen kommer denne egenskab til at dominere. (I955: II9)

The consequence of a passive, phenomenological understanding is that it is first and foremost the surface of things that are fixed on paper; the fleeting, unreflective impression often captures but the most prominent quality of that thing, and it is this quality that comes to dominate the description.

2 The distinction between reality as perceived and reality itself is, according to James Nagel (I980: 22) what separates impressionism from earlier conventions of realism: «the two may be harmonious, an assumption central to Realism, but more often there is discord caused by factors within reality that distort its sensory signals (distance, fog, obscure sounds, darkness, obstructions) or within the receiving interpretive intelligence (fears, dreams, fantasy, preoccupations). The logic of Realism depends on a consistent reliability of both interpretation and perception; the logic of Impressionism suggests that this correspondence is never certain and that the inscrutability and flux of life are its fundamental reality». Italics in the original. 
Kristensen then goes on to meticulous stylistic examinations of novelistic descriptions where the guiding principle is phenomenological apperception, an assessment interesting on its own, although his examples bear no resemblance to Tavaststjerna's prose. As we will see, the significance of the protagonist's perceptive act in Tavaststjerna's short story is of a different, almost paranormal nature: if, in Impressionisten, too, 'the surface' and 'the dominant quality' of the thing observed are awarded the greatest importance, it is because they alone allow Marck, the impressionist, to predict future events.

In her essay Literary Impressionism and Phenomenology: Affinities and Contrasts (1984), Kronegger locates the philosophical groundings of impressionism in Ernst Mach's work Die Analyse der Empfindungen (The Analysis of Sensations) from I885 and stresses, just like Carrabino, how sensorial perception provides a meeting ground for impressionism and phenomenology:

With Ernst Mach and the impressionists, the antithesis of ego and world, sensation and thing, vanishes. All that exists is in contact with everything else. The German critic Hermann Bahr calls Mach's views the "philosophy of impressionism" [...]. With Mach and the impressionists, man's consciousness is the point of departure for any perception. Both impressionists and phenomenologists derive their conceptions of reality from sense impressions: it is in this context that there may be said to be an affinity between them. (Kronegger I984: 524)

While pinning down the nucleus of literary impressionism in an article entitled Phenomenology and Literary Impressionism: the Prismatic Sensibility, H. Peter Stowell correspondingly highlights the importance of a perceiving consciousness whose impressions are facts in the impressionist text: «The impressionist takes the world of appearances as reality, rather than struggle with the phantom issue of appearance versus reality. Each impression, then, is real» (Stowell I984: 538).

As our critical gaze now shifts from the painter-protagonists in the short stories investigated above to the examination of Impressionisten's impressionable subject, we can conclude that Tavaststjerna's short story resonates with phenomenology as practised by the impressionists in its presentation of the act of perception as the vehicle of knowing and understanding not simply objects, but people and identities. Reflection and analysis are here subordinate to the impression, the latter capable, on its own, of becoming a form of clairvoyance. No longer is there a gap between impression and knowledge, between appearance and reality: impression is knowledge and appearance is reality ${ }^{3}$.

3 These affirmations agree with David Hume's treatise on the supremacy of impressions 
Tavaststjerna opens his short story with an explanation of painterly impressionism that perfectly resonates with Kronegger's idea of the centrality of perception to impressionist representation. According to Kronegger, the act of perception is «more important than either the perceived or the perceiver. No longer is there me the narrator-protagonist, on the one hand, and that tree, on the other; there is only my seeing, retaining, or remembering that tree» (1984: 523). Impressionisten similarly makes its argument emphasizing that to the impressionists, the mental act of observation is more valuable than both their own role as observers and the subject observed:

\begin{abstract}
När man nu till dags talar om impressionister, förstår man gärna en del franska målare, som sträva efter att i sin konst möjligast noggrant återgifva de intryck de erfarit vid åsynen af ett landskap, en person o. s. v., mera än själfva landskapet och personen» (Tavaststjerna I892: 13; «Nowadays, when we speak of impressionists, we are likely to indicate by the term a group of French painters, who in their art strive to reproduce as carefully as possible the impressions they have taken in while observing a landscape, a person etc., rather than the landscape and the person themselves») 4 .
\end{abstract}

Proceeding from his first-person point of view, the impressionist in Tavaststjerna's short story builds psychic knowledge from the appearance of things. As the story is set «tidigare än impressionismen fans till som skola» (I892: 13; «before impressionism existed as a school»), knowledge comes to the protagonist Marck not as the result of learning a technique by the rules, but as a strong intuitive act available to «känsliga nervsystem» (Ibidem; «sensitive nervous systems»): «han egde i hög grad den nervernas och förståndets känslighet, hvilken sedermera likt en epidemi gripit omkring sig i vida kretsar och aflat impressionisten som konst, spiritismen som religion, mystiken och symbolismen som literatur» (I4; « he possessed to a great extent that sensitivity of the nerves and the intellect, which lately

compared to ideas. As Ian Watt (I980: I7I) writes: «David Hume [...] opened A Treatise of Human Nature (I739-I740) with the ringing assertion, "All the perceptions of the human mind resolve themselves into two distinct kinds, which I shall call IMPRESSIONS and IDEAS." He had then attributed greater "force and violence" to impressions, as opposed to ideas, which he defined as merely the "less lively perceptions" which occur when we reflect on our original sense-impressions». Italics and capital letters in the original.

4 In Finland, as we have seen, impressionism had a smaller impact on the art world than in the other Nordic countries and was represented, in the main, by Victor Westerholm, whose impressionist paintings did not gain the appreciation of the critics although they appear as «de mest fullödiga exempel på nordisk impressionism» (Gunnarsson 2002: 35; «the most perfect examples of Scandinavian impressionism»). 
has come to generate impressionism in art, spiritism in religion, mysticism and symbolism in literature»).

The plot is simple. Set in a Finnish coastal town first and in the urban environment of Helsinki later, the story unfolds in the time span of a year and centres on a group of friends captained by Marck, a young student who proves able to reveal the true nature of people and foresee their destinies by judging them from their appearances. It is mere intuition that enables him to identify criminals and predict his own death, which occurs at the end of the tale. Although Marck's swiftly captured impressions unfailingly disclose the essence of persons, the anonymous narrator still calls attention to the problematic nature of subjective perception, and a rift soon opens up between the narrator's «eftertanke» (I6; «reflection») and Marck's «instinkt» (Ibidem; «intuition»), judged by the former to be pure madness:

\begin{abstract}
Vi hade då och då skarpa dispyter om hans metod, jag motsade honom af princip och kallade det narraktigt att låta sitt sunda omdöme förblindas af ett dunkelt intryck, som man knapt kunde göra reda för och som omöjligt kunde vara ofelbart. Han såg då på mig med en sällsam, tänkande blick, utan ett spår af skämtsamhet och sade:

- Dumme djur, som förlorat din instinkt!

Jag tog upp handsken och svarade att min eftertanke ersatte instinkten hundrafaldt. (Ibidem)
\end{abstract}

\begin{abstract}
At times we had violent arguments regarding his method, I contradicted him on principle and defined it silly to allow one's common sense to be blinded by an obscure impression of which no account could be given and which could impossibly be infallible. In response, he looked at me with strange, thoughtful eyes, and there was not a trace of jesting when he said:

- You are a foolish animal to have lost your instinct!

I grasped the opportunity and answered that my reflection compensated a hundredfold for any instinct.
\end{abstract}

In the dispute between reflection and perceptive intuition, the authority of perception proves victorious in the end. Written in the early I 890 s, when symbolism had started to conquer the art world, Tavaststjerna's short story embraces a different kind of realism by suggesting that our deepest knowledge of the world comes from the sensations that are pressed upon us. The lack of analysis, the reliance on appearances and subjective impressions that characterize the protagonist's perception motivate the title chosen for the short story, although the use of sensorial perception to acquire extra-sensorial, psychic knowledge transcends the idea of impression- 
ism. Tavaststjerna's characterization of impressionism must therefore be defined as broad and inclusive, embracing aspects of symbolism, and that of the impressionist as a far-sighted mastermind. 


\section{4 . \\ SUMMARY}

The characters encountered above have allowed us yet another access to the reflection on the impact of impressionism on Swedish fiction written in the late nineteenth century. To justify the introduction of a painter among the underprivileged characters populating Fattigt folk, Geijerstam chooses a misunderstood avant-garde artist. Although it is likely that any '-ism' in opposition to the official taste would have served the purpose, the adoption of impressionism makes its representative, Ivar Melin, come across as the emblematic misfit - at least initially. Here, the angst-ridden impressionist plays with the thought of abandoning his artistic principles in order to earn a living, knowing that painting according to the taste of art dealers and the public would feed him. However, fidelity to the aesthetic religion recompenses Melin in the end as he manages to sell a painting. Impressionism is thus presented as an ideal worth suffering for ${ }^{\mathrm{I}}$.

If Sven Richert, in Nordensvan's short story, finally enjoys success, it is certainly not because of a faithful observance of impressionism; Richert meets approval only because of the direction towards symbolism that his artistic vision has taken after his nit-picked impressionist phase.

In the company of worthy, non-conformist, painters such as Ivar Melin and Sven Richert, Nordensvan's other two artists, Aja Borgström and Nisse Linder, seem to feign adherence to a fashionable trend in painting, while

I When tracing the myth of the artist in French prose, Émilie Sitzia concludes that the French novel of the nineteenth century resorts to the 'Promethean' model of the artist in conflict with power, whose destiny is tragic when it comes to identifying the 'true' artist as opposed to the fraud, i.e., the 'Pygmalion' artist, who honours his masters and is therefore rewarded by them (Sitzia 2004: 30-3I). She writes: «Le XIXe siècle recite donc essentiellement des mythes la révolte, le pouvoir créateur et la fin tragique de Prométhée, et l'amour fou de Pygmalion pour son œuvre. Mais le XIXe siècle reste le siècle de l'échec de Pygmalion» (33; «The nineteenth century recites essentially the myths of revolt, creative power, and tragic ending of Prometheus, and Pygmalion's mad love for his oeuvre. But the nineteenth century still remains the century of Pygmalion's failure»). 
Mathilda Roos's Harry Wijkler and Gustaf Larsson stand out almost as caricatures of the impressionist. Tavaststjerna's portrait of the hypersensitive Marck completes the picture adding a touch of the doomed genius and furnishing the impressionist with almost supernatural qualities, while implanting the movement into a cultural context thriving on spiritism, mysticism, and symbolism - the latter thus not set in opposition to impressionism.

The investigation of the literary life of the Swedish impressionist has resulted in a many-sided portrait: the most convinced impressionist by far is Ivar Melin, who proves willing to sacrifice his life for art; the most uncommitted one is the otiose Harry Wijkler, while the most typical, true-to-life impressionist is Sven Richert, who lives his radical impressionist moment only as a brief stage in his evolution as a painter, before being crowned as a symbolist at the end of the century.

In the above I have also looked at how fiction is used to convey a critical discussion of the means and methods of impressionism, perhaps with the aim, in the case of Geijerstam and Nordensvan, of informing a broader readership than the one these writers were likely to reach with their art criticism. According to Torsten Gunnarsson, the «conceptual uncertainty» characterizing the observations on impressionism supplied by the Scandinavian painters and art critics involved in the debate on modern art, lasted through the I880s (Gunnarsson 2002: 20). Through the examination of fiction, and in Nordensvan's case also of art criticism published in periodicals, I have been able to prove that, by the end of this decade, writers such as Geijerstam and Nordensvan had clearly come to terms with the ambitions of impressionism, although their impressionist characters may not always have (Nisse Linder), or seem to keep fluctuating between impressionist experiments commercially not viable and the representation of obsolete, though marketable, subjects, winning the favour of art critics and buyers (Aja Borgström, Ivar Melin). As Per Hedström points out (2002: IOO), the Nationalmuseum in Stockholm first acquired a French impressionist painting in I9II; before the turn of the century the Swedish public could become acquainted with the movement only through temporary exhibitions in Sweden or during travels abroad.

Understanding is not necessarily synonymous with appreciation, as August Strindberg's approach to impressionism has taught us, and although these texts present discussions on aesthetic ad technical questions, not one of these short stories suggests that the author's motivation lies in broad sympathy with the movement or in the desire to defend impressionist art. In Georg Nordensvan's art criticism, however, it is possible to note a turn towards appreciation in this writer's view on impressionism.

Given the nature of the prose of the two art connoisseurs Geijerstam and Nordensvan, Utan pängar and Aja have also called for an account of how the visual arts are used in the texts. A central concern has therefore been to 
understand the function of an explicit use of the visual arts through ekphrasis and an implicit use, through the exhibition of descriptive passages that stimulate the impressionist's visual imagination.

An issue that could be pursued further is the one concerning form. Of the four texts I have sought to analyze in this part of the present study only one is a novel. Herbert Marcuse has argued that the formal dimensions make a difference in the depiction of artists: the short story, he claims, cannot but represent isolated scenes from the life of an artist and must therefore disassociate from anchoring these episodes to an individual and social context (Marcuse I978: I8-I9). However, he adds, when the narrated episode assumes symbolic value and proves capable of instantly revealing the character of the artist, even the novella can raise questions about artistic vocation (Marcuse I978: I9). As I have pointed out, through the metanarrative discourse of the narrator in Aja, Nordensvan reminds us twice of the fact that his short story, which «kunde ha utvecklat sig till en hel roman» (37; «could have developed into an entire novel») has got what it takes to approach theportrait-of-an-artist genre. Indeed, in Defining the Short Story: Impressionism and Form, Suzanne Ferguson suggests that the narrative strategies of the short story are particularly apt for impressionist fiction (Ferguson I994). 



\section{CONCLUSIONS}

The motto introducing this study is borrowed from Lewis Carroll's Through the Looking-Glass and What Alice Found There (I87I). It was with me even before phrasing the first paragraph, and I believe it captivatingly expresses the irresistible attraction of subjects that seem hard to grasp intellectually. It also points to the difficult, but necessary, attempt that has to be made to bridge the gap between one's personal understanding of intriguing subjects and the wording of this understanding. Over the past few years the notion of 'literary impressionism' has belonged to these, to me, intriguing research subjects. With the aim to frame literary impressionism, a subject, as Alice has it, «rather hard to understand», this study set out to address the question of its existence in Swedish and Finland-Swedish prose in the age of painterly impressionism. Was there an awareness of the notion among literary critics and authors writing in Swedish? If yes, who were these critics and writers? How did they define literary impressionism? What texts written in Swedish would reveal a connection to impressionist writing?

While increasing academic attention to impressionist writing in French or in English is currently contributing to a growing body of critical commentary on the relationship between literature and impressionism (Bowler 20I6; Berrong 2013; Pouzet-Duzer 2013; Saunders 2013 and 20II; Gengembre, Leclerc and Naugrette 20I2; Vouilloux 20I2b; Parkes 20II), only faint echoes of the rather vivacious late nineteenth-century discussion of literary impressionism in Scandinavia have reverberated in the twentieth and twenty-first centuries. Given this lack of scholarly work on the topic, the first brick to this study was laid with the idea that zero results would also have been a result - though hardly a book on the subject. A critical survey of the use of the term in literary criticism published in the Finland-Swedish press proved, however, that the term did recur in the critical discourse, particularly in the 'age of impressionism', and, in a later stage of the project, I discovered that there were writers, like Stella Kleve, comfortable with the 
term 'impressionist' as a self-definition. Literary impressionism, then, was not merely a «mythe fécond» (Vouilloux 20I2a) but a reality as well - perhaps marginal within the context of Swedish literature, but also historical, one that could be approached empirically.

As the critical survey conducted on the pages of newspapers and Finsk tidskrift demonstrates, the term was used not only to indicate the various ways in which writers were thought to adapt to fiction the technique of painterly impressionism. As a province of critics and authors alike, literary impressionism was also a notion with which to indicate texts drawing on a scenic narration reminiscent of the technique developed by Herman Bang in the mid-I88os, or used with reference to works presented as a subjective deviation from naturalism, as well as a term employed to stigmatize fragmentary, insubstantial, apparently negligent compositions. As the circle, in the course of the critical survey, closed around the years I880 and I900 and, in one way or another, around a few recurring names of writers such as Herman Bang, Hans Jæger, Christian Krohg, August Strindberg, Gustaf af Geijerstam, Georg Nordensvan, Mikael Lybeck, and K.A. Tavaststjerna, a quest for texts written in Swedish that could exemplify these numerous variations on the theme was initiated. Although many of the critical opinions examined in the survey appeared too shallow and, it must be said, too 'impressionistic' to be of real help in the process of singling out works representative of the wide-ranging Scandinavian idea of literary impressionism, these brief reviews did, however, put me on the track of Helena Westermarck, whose short story Aftonstämning, I found, could be read as an example of the transposition of the motifs and methods of painterly impressionism into words, as well as to Stella Kleve, whose I88os production does reveal many of the different facets of literary impressionism ranging from Bang's scenic method to metonymic description, and to the transmission of raw, mentally unprocessed sensory data.

The writers' awareness of impressionism has also been examined through an investigation into works of fiction featuring impressionists in the role of protagonists or secondary characters. Since this study considers literary impressionism as «a historical phenomenon but a semantically mobile term» (Bradbury and McFarlane i976: I) labelling not only works of literature that engage with painterly impressionism, it is interesting that we should find a character among these fictional impressionists who is not a painter but a clairvoyant with a hypersensitive nervous system; Marck, in K.A. Tavaststjerna's Impressionisten. This detail can be seen as a confirmation of the pluralistic approach to literary impressionism evident in the late nineteenth-century Scandinavian discussion of the concept, an approach which I have strived to maintain in my methodology.

The examples brought up for discussion in this study give credit to the existence of models of impressionist texts in Swedish literature, and also 
reinforce the gap between the inclusive understanding of literary impressionism that traditionally has existed in Scandinavia, and the somewhat more restrictive use of the term in an international context ${ }^{\mathrm{I}}$. Although scholars unfamiliar with the early Scandinavian debate regarding literary impressionism might not have to battle with the bohemian understanding of impressionism as a warranty for turning naturalism into subjective, autobiographical writing, the «critical chaos» (Matz 200I: I6) surrounding the theme seems almost universal. This brings us back to the 'irresistible attraction of subjects that are hard to grasp intellectually', expressed in the motto chosen for this book: every other scholar with an interest in literary impressionism stresses the problem of arriving at a valid definition of a notion comprizing such a multitude of characteristic expressions (see, e.g., Kronegger I973: 23; Matz 200I; Peters 200I) - in Wylie Sypher's words on the impressionists (I960: I7I): «how are we to reconcile these competing techniques into a movement?». Similarly, Bert Bender reflects on the usefulness of identifying Stephen Crane's prose with literary impressionism as the concept seems much too vast and multifaceted to say something constructive about the qualities of Crane's writing, and concurs: «being unique, Crane's vision demands its own term» (Bender I976: 53). This difficulty of definition and the vagueness surrounding the idea of literary impressionism have led scholars to mistrust the term's critical value - «"impressionism" in literature has become an almost meaningless concept» (Bender I976: 50) - and consequently to put forward proposals to revoke the term as the only solution to the dilemma of definition (Berrong 2013: 23; Cuddon I991: 446; Brown i968: 59).

The present study has countered these opinions with its investigation into the historical awareness of impressionism in Swedish literature. The aforementioned survey of literary criticism has left us with a result reflecting a multiplicity of interpretations of the category of literary impressionism suggesting that this approach to explaining the phenomenon is more valuable than single accounts of how literary impressionism suits the individual scholar. By registering the numerous accesses to literary impressionism in the critics' different approaches to the concept, as well as in the writers' diverse appropriations of the tendency, unnecessary limitations to the understanding of the ways in which impressionism resonated within Swedish literature at the end of the nineteenth century have been avoided. Thus, the results stemming from this survey help to address the undying quandary of the 'usefulness' of a critical category as multifarious as literary impressionism. These results demonstrate, I believe, that, since its first appearance, the idea of 'literary impressionism' corresponded to a «family of meanings»

I Cf., Dahl I98I: 92; «den ekstensive nordiske vs. den intensive europeiske [...] betydning av begrepet impresjonisme» («the extensive Nordic vs. the intensive European [...] meaning of the concept of impressionism»). 
(Wittgenstein I953: 36e), and that the indistinctiveness that comes with the employment of this notion is exactly what we need to be able to embrace the variety of concerns that are at stake when we speak of literary impressionism. To be useful, a discourse on literary impressionism then has to depart from the idea that impressionist texts and impressionist writers should not be narrowed down to one fundamental common feature, and the one attempting this discourse should, ungrudgingly, and in Wittgenstein's words, «travel with the word's uses» (I953: 32e). This approach is particularly useful to organize an initial discourse on literary impressionism within the context of Swedish literature, where there is no consistent scholarly tradition investigating the notion to rely on.

Although the adoption of a multifaceted perspective has allowed me to address a great number of the many questions prompted by the term literary impressionism, not all of these have been fully explored, and some might offer material for further research. With a little extra work, part II of this study could be enriched with additional analyses of texts showing the variety of literary impressionisms. In its present form, the examples brought up for discussion cover the idea of literary impressionism as a matter of interart transposition, and also discuss scenic impressionism as well as narrative modes catering for the transmission of a subjective perception. As such, the two main, and internationally recognized, interpretive lines of literary impressionism are at the basis of the investigation, although the prose work of Stella Kleve does accommodate an analysis of characteristics specific to the Scandinavian understanding of the phenomenon ${ }^{2}$. However, examples of Swedish prose adopting a bohemian impressionist stance could offer new insights into the interpretation of impressionist literary modes. Also, a rethinking of the ways in which plein air prose and poetry engaged with impressionist aesthetics at the turn of the nineteenth century, as suggested in the literary criticism taken into consideration in part I, as well as in a few studies dedicated to 'impressionist poetry' (Malmström i968; Olsson I983; Johansson 20II) could prove fertile, providing that the methodological instruments are refined. In addition, although the Finland-Swedish press also allows insights into impressionst writing in Sweden, the current digitalization of Swedish newspapers, which is being carried out at the Kungliga Biblioteket in Stockholm, will undoubtedly prove helpful for a future inves-

2 Cf., e.g., Vouilloux 2oı2b: 2; «le modèle explicative mis en jeu à l'apparition de la notion aura connu deux grandes variantes» («the explicative model which was introduced as soon as the notion appeared has known two basic variations»). Vouilloux explains these as the line of Brunetière and that of Bourget: «la littérature s'aligne purement et simplement sur le matérialisme de la peinture (c'est l'hypothèse de Brunetière); ou bien littérature et peinture, dans leur version impressionniste, sont les symptômes d'une même attitude caracterisée par la prédominance de la subjectivité (c'est l'hypothèse de Bourget)» (Vouilloux 20I2b: 3; «literature aligns purely and simply with the materialism of painting [Brunetière's hypothesis]; or else literature and painting in their impressionist versions, are the symptoms of a similar attitude characterized by a predominant subjectivity [Bourget's hypothesis]»). 
tigation of how literary impressionism as a critical term was used historically also in Sweden.

When Herman Bang himself reflected on the usefulness of the term, he realized that the value of literary impressionism would emerge only when subsequent tendencies concentrating on different narrative aspects had come to replace it: «den impressionistiske Fortælleform vil vel, som alle Kunstens Former, kun have sin Tid. Men selv den Dag, hvor den er afløst af en ny Form for Fremstillingen, vil Impressionismens Nytte spores» (Bang I89oa: 694; «narrative impressionism, just like any other form of art, is surely destined to live out its life. But the very day it is replaced by another form of representation its usefulness will be revealed»). In a line directed to young Stella Kleve he seems to reinforce this opinion in a highly personal way: «lad kun Bladene skælde mig ud! Danmarks Litteraturhistorie vil engang være god mod mig» (Malling I920: 220; «just let the press condemn me! One day the history of Danish literature will be good to me»). An investigation of what resonances a movement like impressionism, which in the history of art stands out as a turning point, left on literature is indeed valuable if we wish to widen the understanding of the fin-de-siècle. An oversimplified, though common, sweeping view of the cultural climate of the Scandinavian I880s and the I89os deems the former decade as permeated by the grey skies of naturalism and the latter as imbued with neo-romanticism, symbolism, and decadentism. A look at the writers' engagement with impressionism might then help to explain a facet of modern realism and construct a more nuanced account of the literature of that period: the examples of Helena Westermarck and Stella Kleve discussed in the central chapter of this study show that impressionism could combine with themes that occupied the naturalists, such as social injustice, as well as with the modern theme of female eroticism.

Though a marginal phenomenon in Swedish literature, and geographically marginal with reference to the birthplace of impressionism in painting and in literature, through its choice of topic this book still wishes to enter the international dialogue on literary impressionism with the ambition of showing that original variations on «un concept confus mais durable» (Rubin 20I2: II; «a confusing yet durable concept») are to be found precisely in the margin. If the difficulties in arriving at a definition of literary impressionism at times have appeared insurmountable, to such an extent that the term has seemed more confusing than useful, the growing corpus of scholarly research proves that literary impressionism continues to challenge critical thought and that we have to learn to deal with the notion somehow. The study that you are holding in your hands is my proposal. 



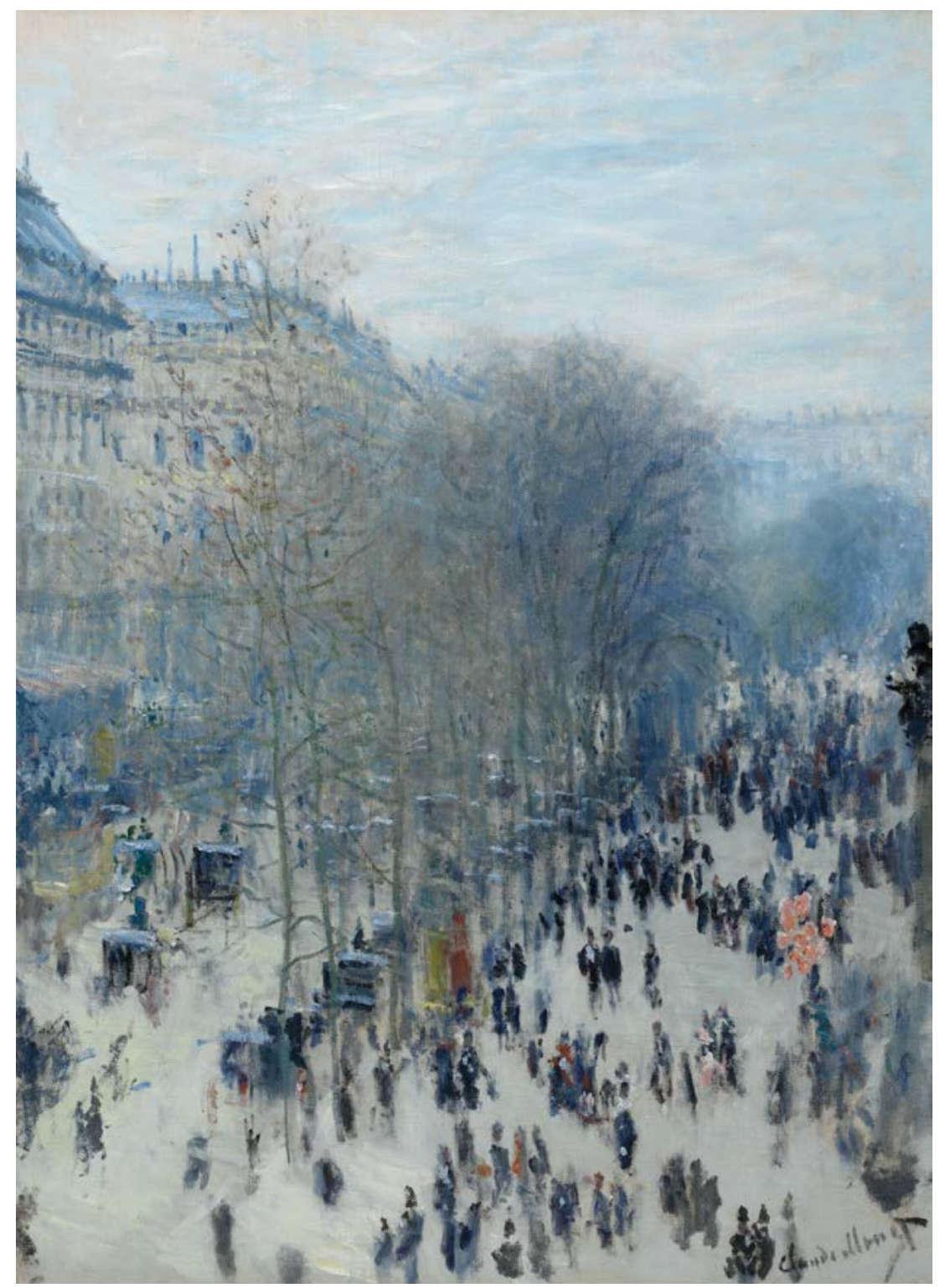

Fig. I 


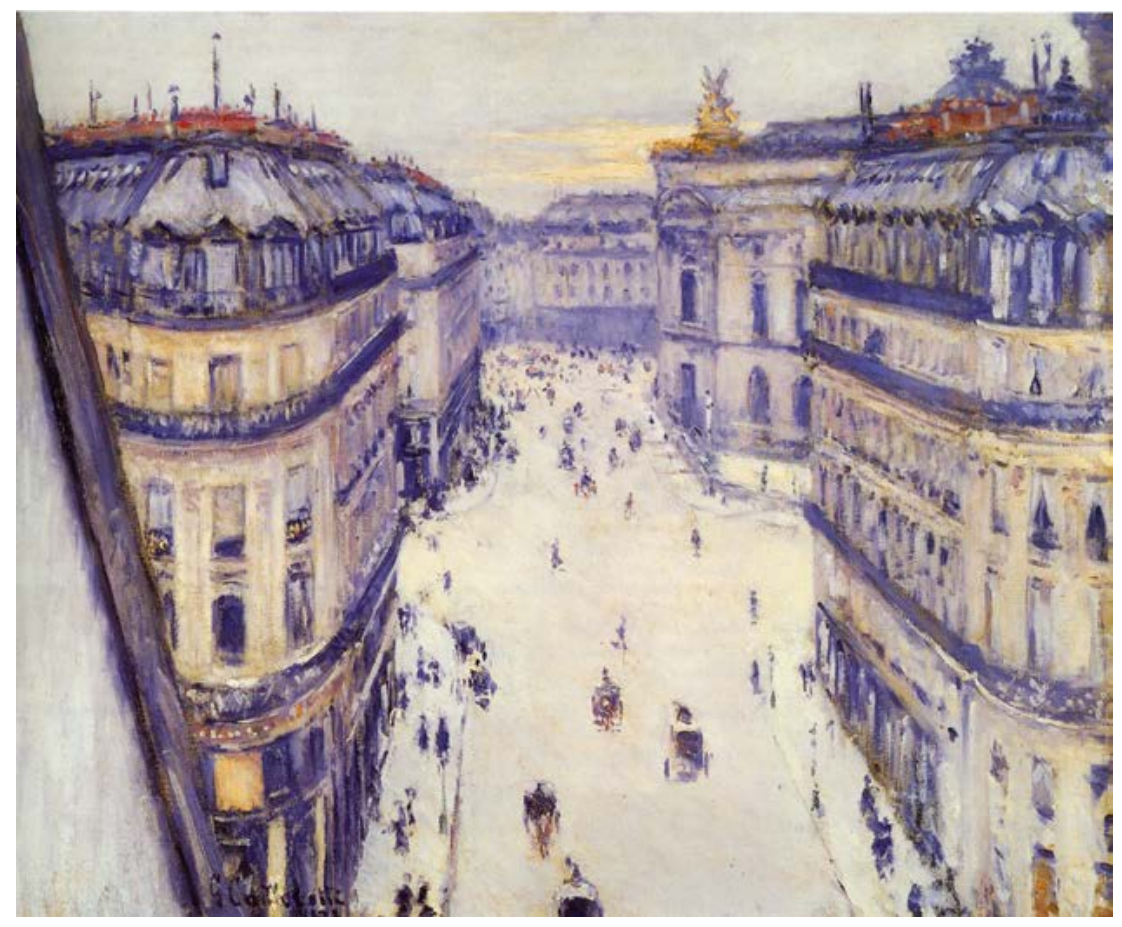

Fig. 2 


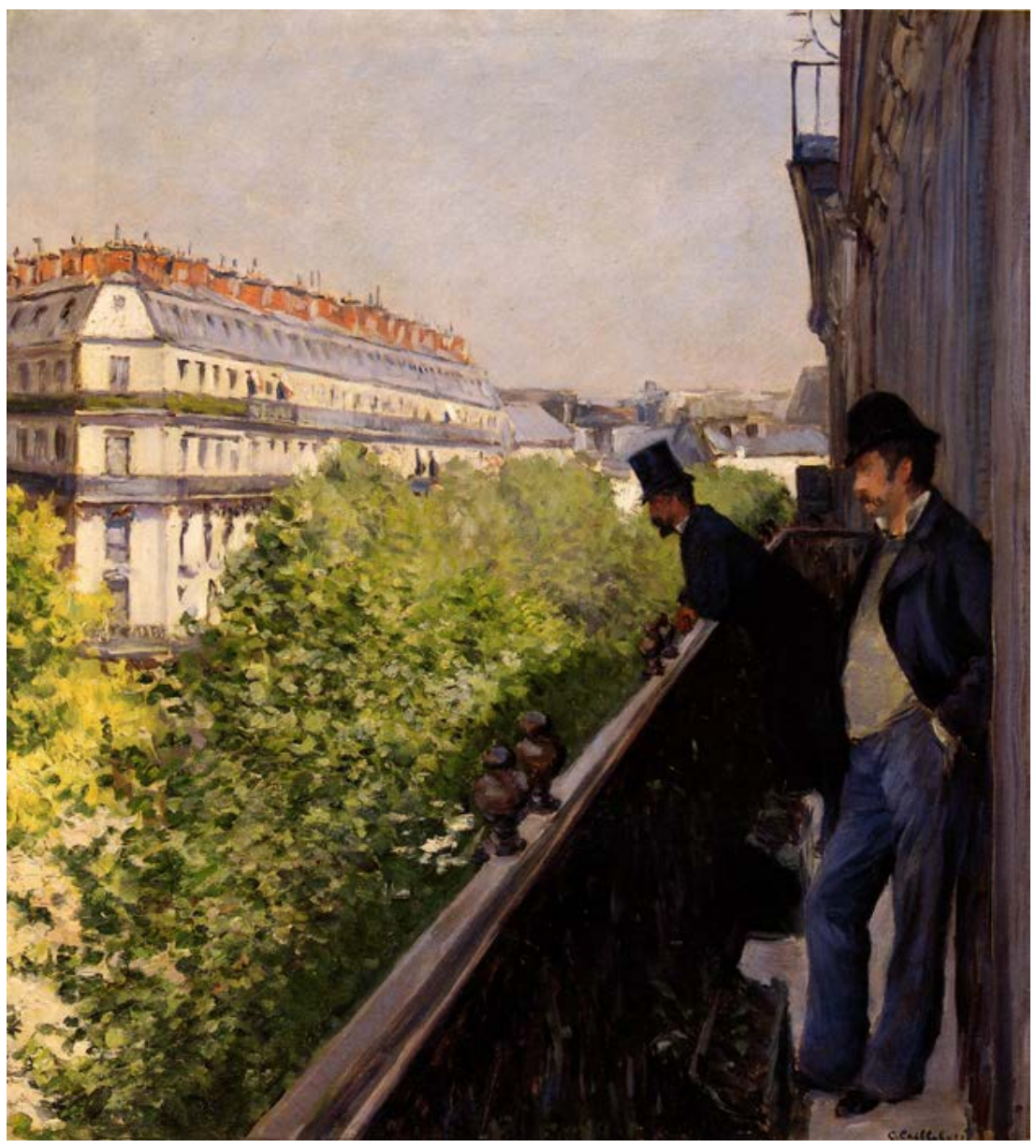

Fig. 3 


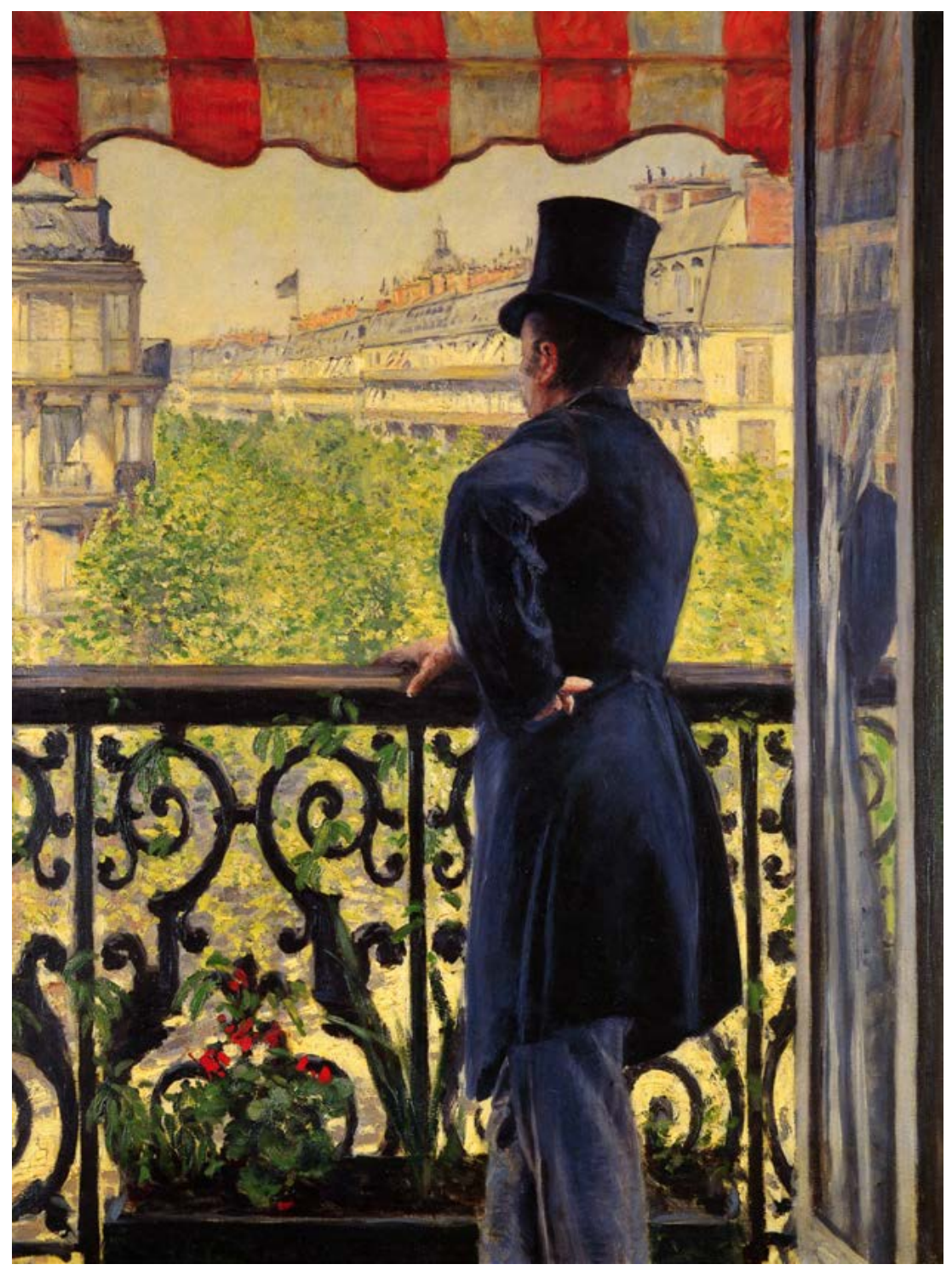

Fig. 4 


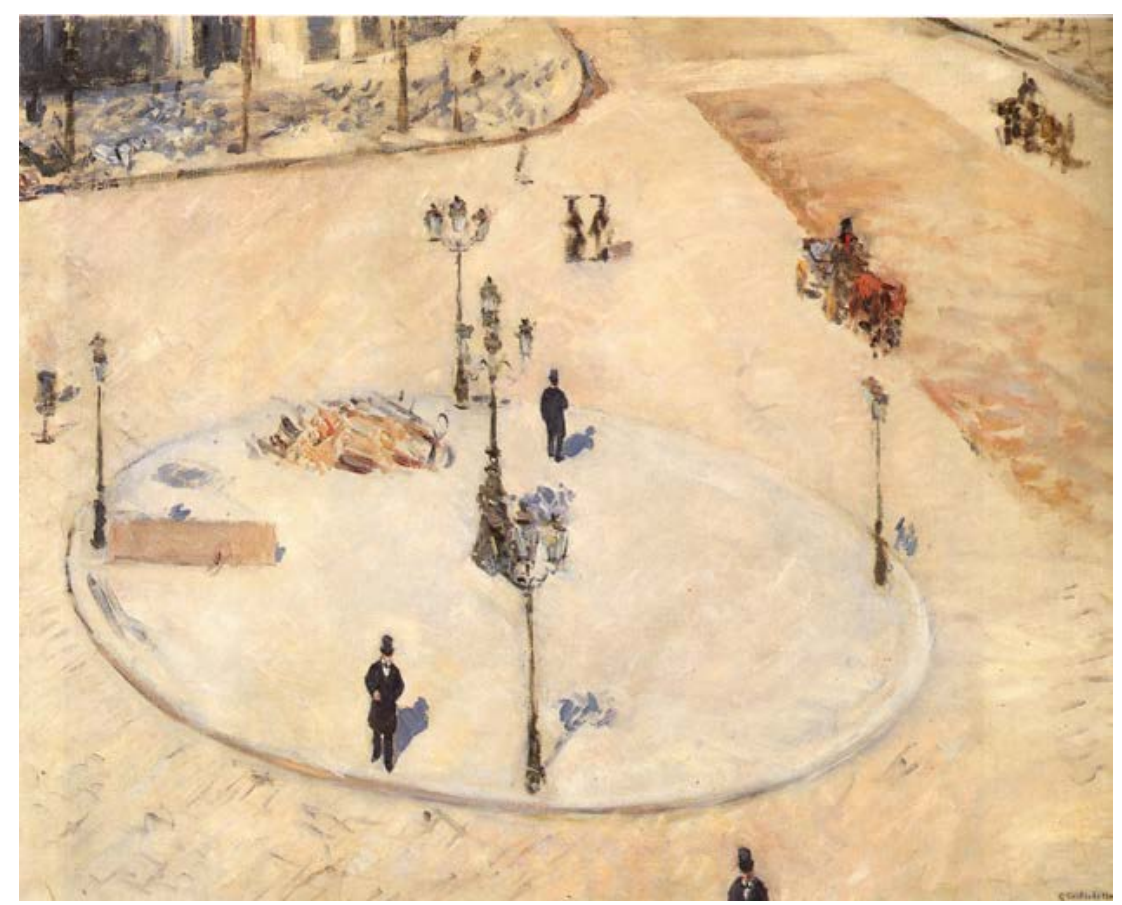

Fig. 5 


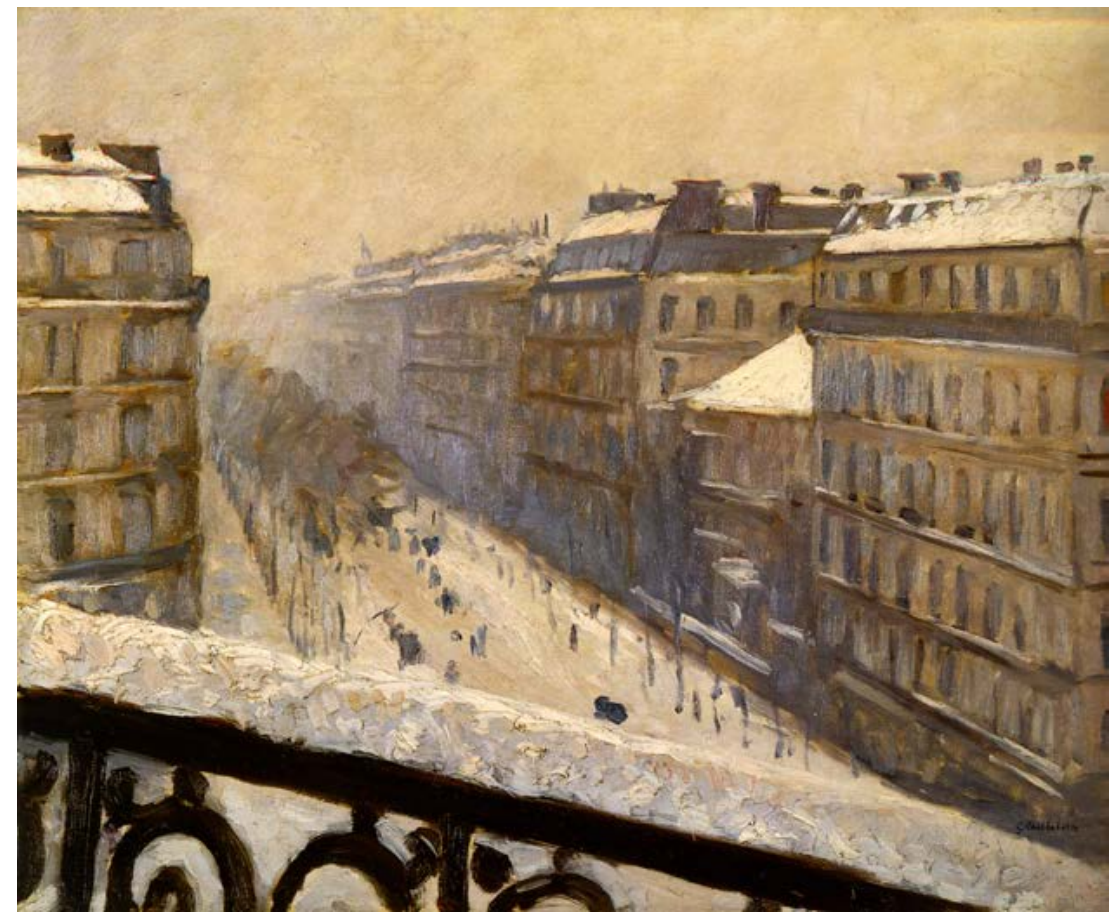

Fig. 6 


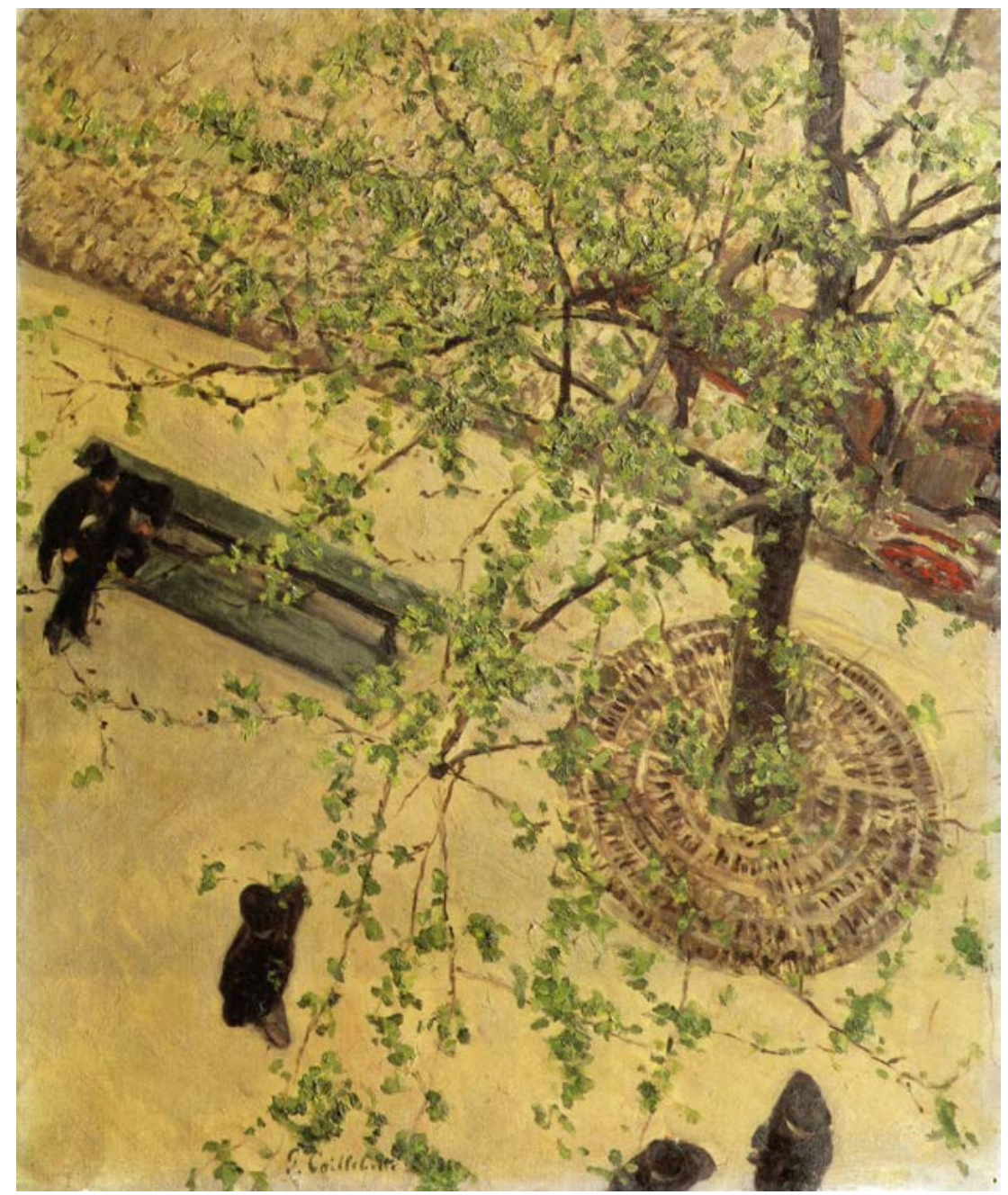

Fig. 7 


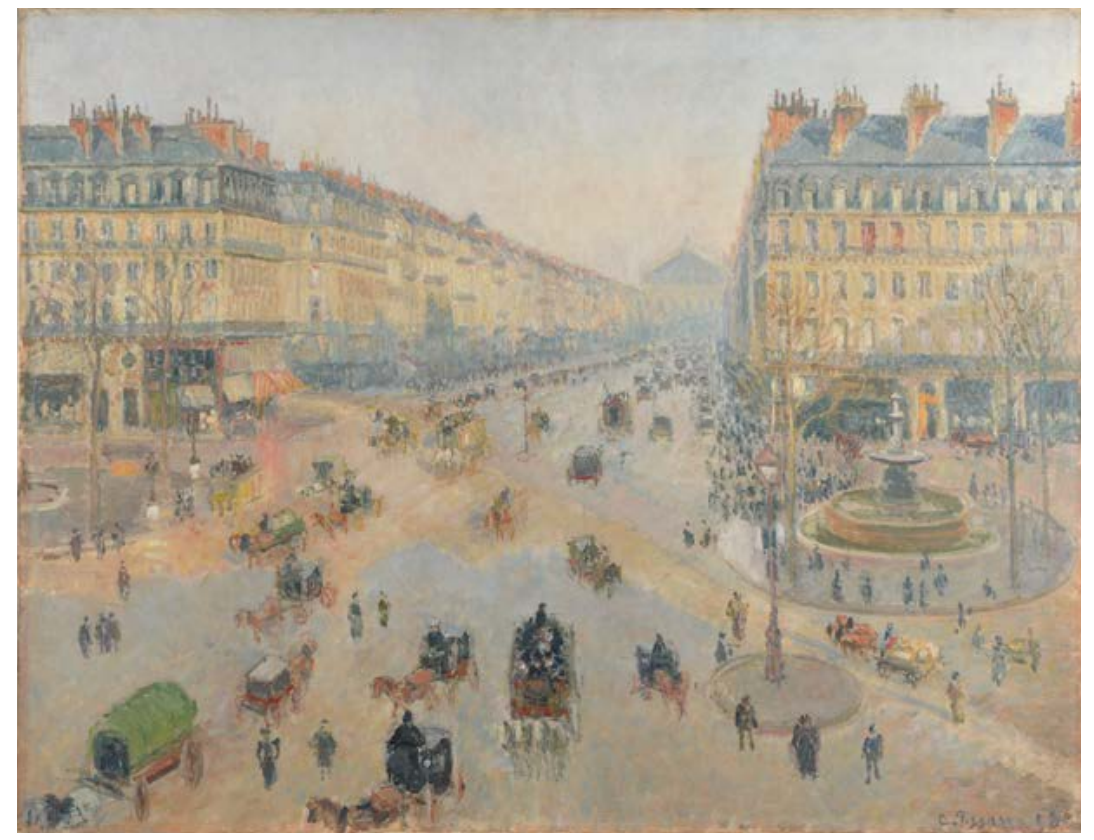

Fig. 8 


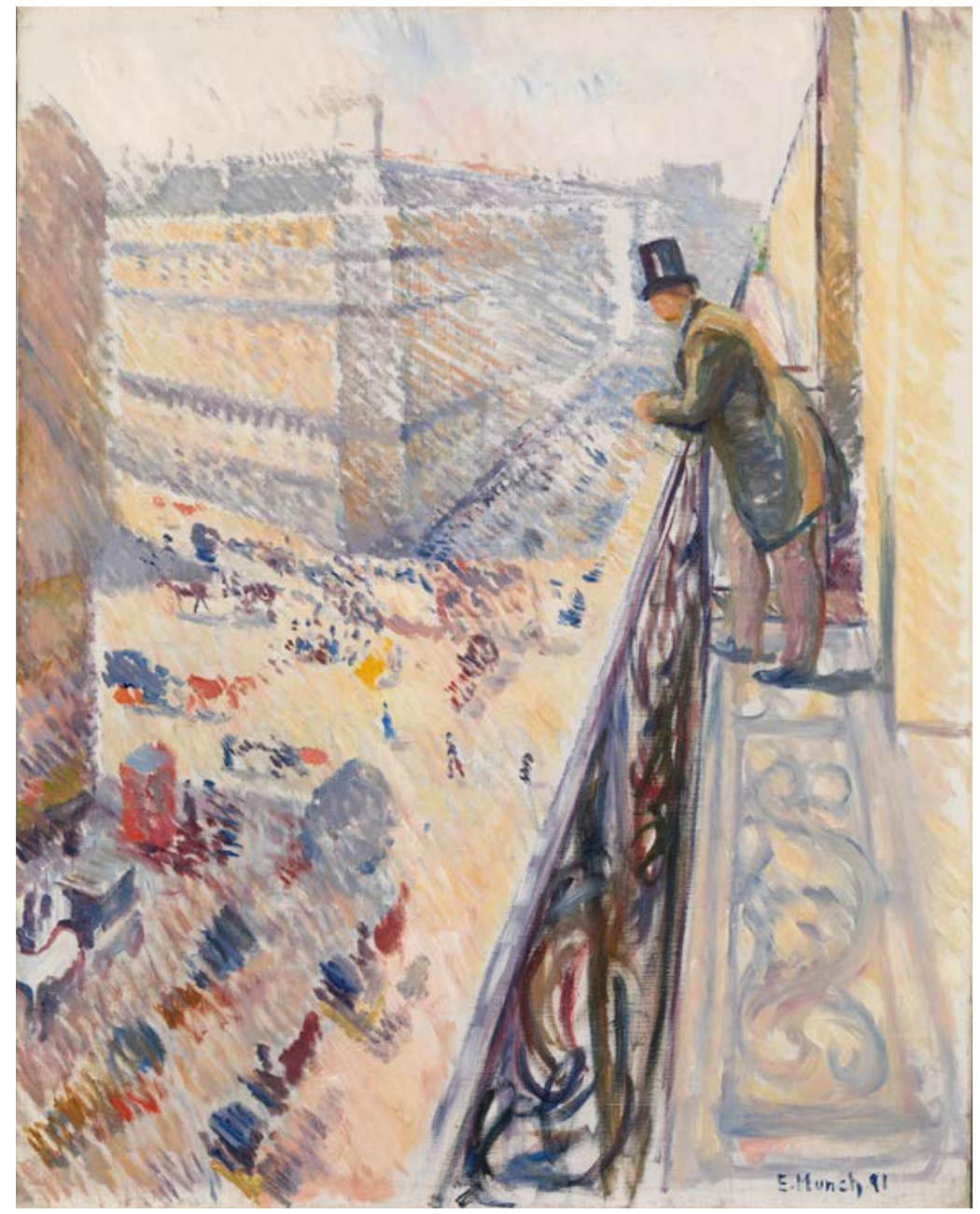

Fig. 9 


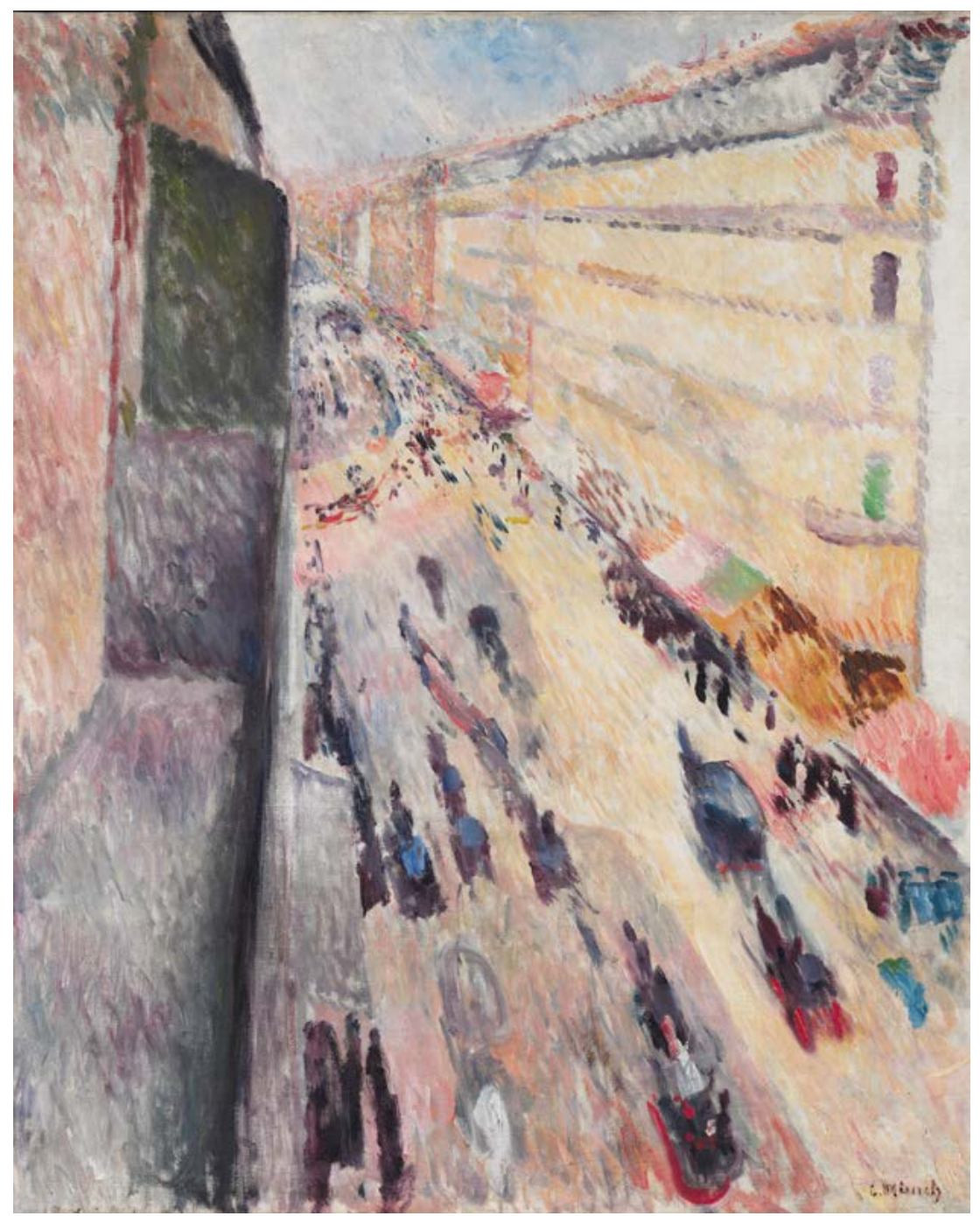

Fig. IO 


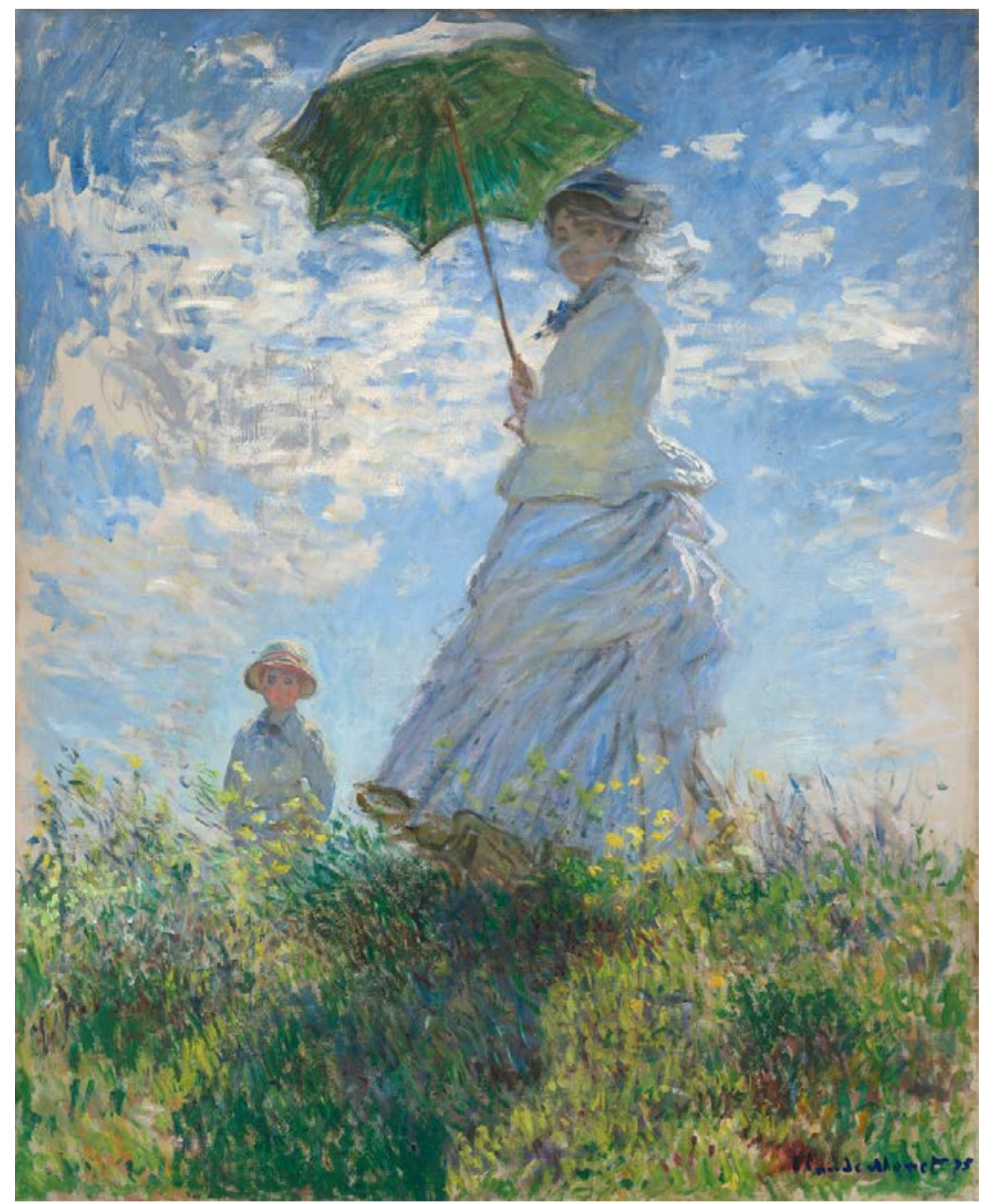

Fig. II 


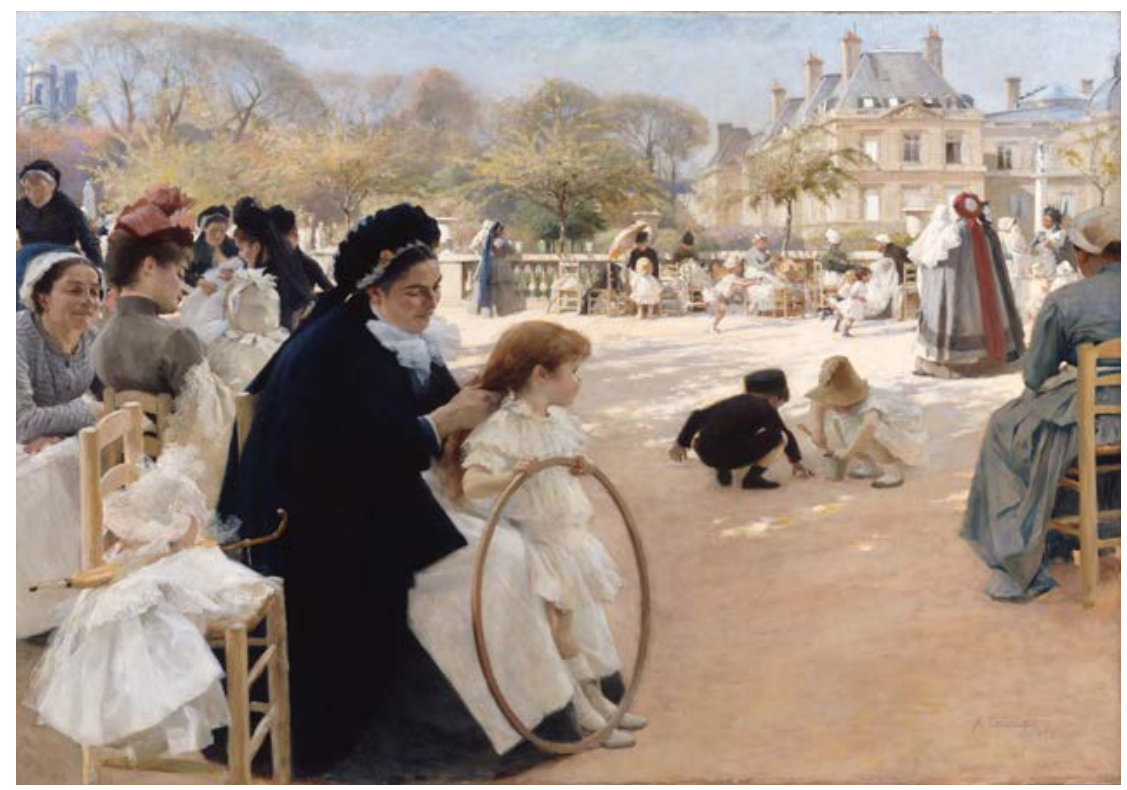

Fig. I2 


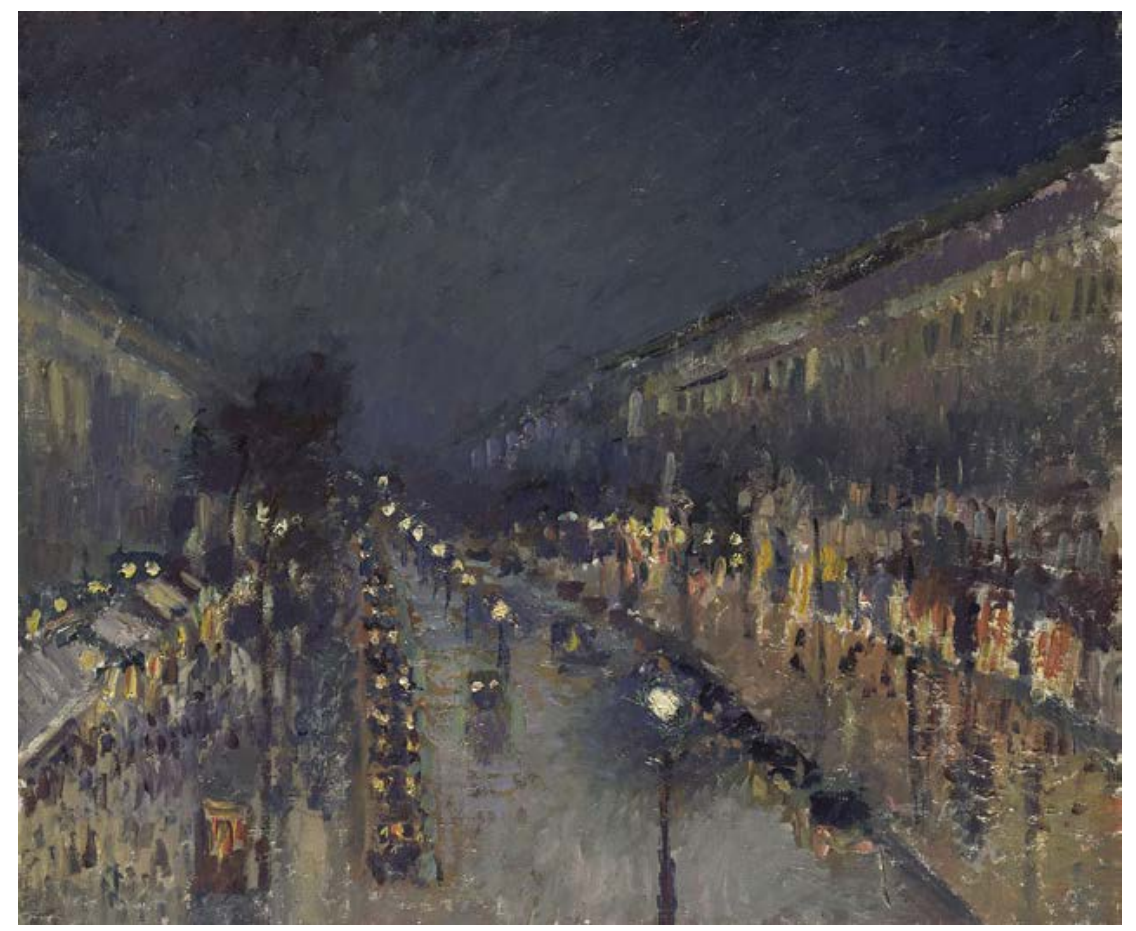

Fig. I3 



\section{List of illustrations}

Fig. I: Claude Monet. Boulevard des Capucines, oil on canvas, $80.3 \times 60.3 \mathrm{~cm}$, I873-74. (C)The Nelson-Atkins Museum of Art, Kansas City (MO). Purchase: the Kenneth A. and Helen F. Spencer Foundation Acquisition Fund, F72-35. Photo: Jamison Miller.

Fig. 2: Gustave Caillebotte. Rue Halévy, vue d'un sixième étage (Rue Halévy, Seen from the Sixth Floor), oil on canvas, $60 \times 73 \mathrm{~cm}, 1878$. Private collection.

Fig. 3: Gustave Caillebotte. Un Balcon, boulevard Haussmann (A Balcony, boulevard Haussmann), oil on canvas, 69 × $62 \mathrm{~cm}$, I880. Private collection.

Fig. 4: Gustave Caillebotte. Homme au balcon, boulevard Haussmann (Man at the Balcony, Boulevard Haussmann), oil on canvas, II7 x $90 \mathrm{~cm}, \mathrm{I} 880$. Private collection.

Fig. 5: Gustave Caillebotte. Un Refuge, Boulevard Haussmann (A Traffic Island, Boulevard Haussmann), oil on canvas, 8I x IOI cm, I880. Private collection.

Fig. 6: Gustave Caillebotte. Boulevard Haussmann, effet de neige (Boulevard Haussmann, Effect of Snow), oil on canvas, $65 \times 82 \mathrm{~cm}$. Private collection.

Fig. 7: Gustave Caillebotte. Boulevard, vu d'en haut (Boulevard, Seen from Above), oil on canvas, I00 x 8I cm, I880, Private collection.

Fig. 8: Camille Pissarro. Avenue de l'Opéra, oil on canvas, 73 x $92 \mathrm{~cm}$, I898. (C)Musée des Beaux-Arts de la Ville de Reims. Photo: Christian Devleeschauwer.

Fig. 9: Edvard Munch, Rue Lafayette, oil on canvas, $92 \times 73 \mathrm{~cm}$, I891. (C) Nasjonalmuseet for kunst, arkitektur og design, Oslo. Photo: Børre Høstland.

Fig. Io: Edvard Munch, Rue de Rivoli, oil on canvas, 8I x 65.I cm, I89I. Harvard Art Museums/Fogg Museum, Cambridge (MA). Gift of Rudolf Ser- 
kin 1963.I53. (CThe Munch Museum/The Munch-Ellingsen Group/Artists Rights Society (ARS), New York. Photo: Imaging Department, (C) President and Fellows of Harvard College.

Fig. II: Claude Monet. Woman with a Parasol. Madame Monet and Her Son, oil on canvas, I00 x 8I cm, I875. Collection of Mr and Mrs Paul Mellon. Courtesy National Gallery of Art, Washington.

Fig. I2: Albert Edelfelt. I Luxembourg-trädgården i Paris (The Luxembourg Gardens, Paris), oil on canvas, I4I. 5 x I 86.5 cm, I887. Antell Collection. Helsinki, Ateneum Art Musem. Photo : Finnish National Gallery / Hannu Aaltonen.

Fig. I3: Camille Pissarro. Boulevard Montmartre. La nuit (The Boulevard Montmartre at Night), oil on canvas, 53.3 x 64.8 cm, I897. Courtauld Fund. (C)The National Gallery, London. 


\section{Acknowledgements}

The present study had been germinating in my mind for years. During this time some people have been born and others have passed away. I dedicate this book to my three children and to the memory of my father and mother. I wish to thank friends and family for their support and help. Thanks to my colleague Andrea for attentively reading and commenting on the script, to the staff at the interlibrary loans at the University of Milan, especially Manuela, for her invaluable help, to Pia, for great laughs. For editing, Thomas (and Kim). For their intellectual guidance and encouragement over the years, Massimo and Maria Giulia. A special thought goes to Matteo, for his support and for bearing with me. 



\section{References}

‘Ar'. I895. “Lovart och lä. Bilder och stämningar af Jonatan Reuter.” Hufvudstadsbladet I4 December.

Armstrong, Paul B. I976. Henry James: Impressionism and Phenomenology. Stanford: Stanford University Press.

-. I980. "Literary Impressionism. James and Chekhov by H. Peter Stowell." Criticism 22, 4: 384-386.

-. I987. The Challenge of Bewilderment. Understanding and Representation in James, Conrad, and Ford. Ithaca: Cornell University Press.

Arvidsson, Rolf. I969. Den unge Pär Hallström. Lund: Gleerup.

Bahr, Hermann. I894. Studien zur Kritik der Moderne. Frankfurt am Main: Rüiten \& Loening. Online at www.archive.org/details/studienzurkritiorbahrgoog. Accessed 7 February 2018.

Balducci, Temma. 20I7. Gender, Space, and the Gaze in Post-Haussmann Visual Culture: Beyond the Flâneur. London: Routledge.

Bally, Charles. I920. "Impressionnisme et grammaire." In Mélanges d'histoire littéraire et de philologie offerts à M. Bernard Bouvin I: 26I-279. Genève: Sonor.

Bang, Herman. I889. “To Bøger.” Dagbladet I2 January.

—. I89oa. “'Impressionisme'. En lille Replik.” Tilskueren 7: 692-694.

—. I89ob. “Til Jonas Lie.” In Id., Under Aaget. Noveller, 4-21. København: I.H. Schubothes Boghandel.

—. I893. "Jonas Lie." Samtiden 4, 402-407.

-. I908. "Jonas Lie." Tilskueren 25: 666-681.

-. I920-2I. Ved Vejen. In Id., Voerker i Mindeudgave, eds. Johan Knudsen and Peter Nansen, 7-I64. København: Gyldendal. Online at www.adl.dk/solr_documents/ bangorval-workid54382. Accessed 7 February 2018.

—. I990. Katinka. English transl. by Tiina Nunnally. Seattle: Fjord Press.

Basílio, Kelly. 2007. “Trilles et frétillements. L'écriture 'impressionniste’ du désir dans Une Partie de campagne de Maupassant." In Guy de Maupassant, ed. Noëlle Benhamou, 33-44. Amsterdam / New York: Rodopi.

Baudelaire, Charles. I863. "Le Peintre de la vie moderne." Figaro 26 November.

'B. E.'. I886. “- ii —: Solglöd och andra skizzer.” Finsk tidskrift 21: 28I-283.

Beebe, Maurice. 1964. Ivory Towers and Sacred Founts. The Artist as Hero in Fiction from Goethe to Joyce. New York: New York University Press.

Bender, Bert. I976. "Hanging Stephen Crane in the Impressionist Museum." The 
Journal of Aesthetics and Art Criticism 35: 47-55.

—, and Sue Briggum. I982. "Quantitive Stylistic Analysis of Impressionist Style in Joseph Conrad and Ford Madox." In Computing in the Humanities: Papers from the Fifth International Conference on Computing in the Humanities, Ann Arbor (MI), May I98I, ed. Richard W. Bailey, 59-64. Amsterdam: North-Holland.

Berendsohn, Walter A. I964. "Inledningen till Röda rummet." In Strindbergs språk och stil: valda studier, ed. Göran Lindström, 8I-Io9. Lund: Gleerup.

Berg, Ruben G:son. I92I. "Inledningen till Röda rummet." Svenska Dagbladet 2 October.

Berrong, Richard M. 2006. "Modes of Literary Impressionism.” Genre. Forms of Discourse and Culture XXXIX, 2: 203-228.

-. 20I3. Putting Monet Q Rembrandt into Words. Pierre Loti's Recreation and Theorization of Claude Monet's Impressionism and Rembrandt's Landscape in Literature. Chapel Hill: University of North Carolina Press.

Binding, Paul. 2006. With Vine-leaves in His Hair. The Role of the Artist in Ibsen's Plays. Norwich: Norvik Press.

Bonsdorff, Bengt von. 2002. "I regnbågsfärgernas tecken. Impressionismen och Finland." In Impressionismen och Norden. Det sena 1800-talets franska avantgardekonst och konsten i Norden 1870-1920, ed. Torsten Gunnarsson, 263294. Stockholm: Nationalmuseum.

Bouquet, Philippe. I983. "L'Impressionnisme paradoxal de Herman Bang dans Ved Vejen.” Études Germaniques XXXVIII, 4: 4I7-424.

Bowie, Theodore Robert. 1950. The Painter in French Fiction. A Critical Essay. Chapel Hill: University of North Carolina.

Bowler, Rebecca. 20I6. Literary Impressionism. Vision and Memory in Dorothy Richardson, Ford Madox Ford, H.D. and Mary Sinclair. London: Bloomsbury.

Bradbury, Malcolm, and James McFarlane. I976. Modernism 1890-1930. London: Penguin.

Brandes. Georg. I90I. "Edmond og Jules de Goncourt.” In Id., Samlede skrifter 7: IOI-I24. København: Gyldendal. Online at www.runeberg.org/gbsamskr/7/0I05. html. Accessed 7 February 2018.

Briens, Sylvain. 2010. Paris, laboratoire de la littérature scandinave moderne: 18801905. Paris: Harmattan.

Brown, Calvin S. I968. "How Useful Is the Concept of Impressionism?" In Symposium in Literary Impressionism, Yearbook of Comparative and General Literature, eds. Henry H.H. Remak and Ulrich Weisstein, I7: 53-59. Bloomington (IN): Indiana University Press. Online at https://archive.org/details/ yearbookofcomparoi7776mbp. Accessed 7 February 2018.

Brummer, Hans Henrik. 2002. "Scandinavian Impressionism - Did It Exist?”. Art Bulletin of Nationalmuseum Stockholm 9: 77-80.

Brun, Sarah. 20I2. "Le Peintre impressionniste sur scène: Marignan dans La Cigale de Meilhac et Halévy (1877) et Alaric Gigonnet dans Les Impressionnistes de Grangé et Bernard (I878).” In Impressionnisme et littérature, eds. Gérard 
Gengembre, Yvan Leclerc and Florence Naugrette, I89-I99. Rouen: Presses universitaires de Rouen et du Havre.

Brunetière, Ferdinand. I879. "L'Impressionisme dans le roman." Revue des deux mondes XLIX, 36: 446-459.

—. I88I. “Om reporter-skildringar i romanen." Finlands allmänna tidning 27 October.

Burgess, Anthony. 20I4. "Novel”. http://www.britannica.com/EBchecked/ topic/42107I/novel/50992/Impressionism. Accessed I3 January 2015.

Busk-Jensen, Lise, Per Dahl, Anker Gemzøe, Torben Kragh Grodal, Jørgen Holmgaard and Martin Zerland (eds). I985. Dansk litteraturhistorie 6: Dannelse, folkelighed, individualisme 1848-1901. København: Gyldendal.

Caramaschi, Enzo. I985. Arts visuels et littérature: de Stendhal à l'impressionnisme, Fasano / Paris: Schena / Nizet.

Carlander, Cecilia. 2013. Les Figures féminines de la décadence et leurs implications esthétiques dans quelques romans français et suédois, $\mathrm{PhD}$ dissertation. Institutionen för litteratur, idéhistoria och religion, Göteborgs universitet and UFR de littérature française et comparée, Université Paris-Sorbonne. Online at http://www.ub.gu.se/ kvinn/gena/search/details.html?id=2246. Accessed 7 February 2018.

Carrabino, Victor. I984. "The French Nouveau Roman: The Ultimate Expression of Impressionism.” In Analecta Husserliana. The Yearbook of Phenomenological Research XVII: The Existential Coordinates of the Human Condition: Poetic - Epic - Tragic. The Literary Genre, ed. Anna-Teresa Tymieniecka, 26I-270. Dordrecht / Boston / Lancaster: Reidel.

Choi, Young Sun. 20II. “'All Glittering with Broken Light': Katherine Mansfield and Impressionism." Katherine Mansfield Studies 3: 67-80.

Christensen, Georg. 19I8. "Herman Bangs teknik.” Edda I: 57-80.

Clüver, Claus. I997. "Ekphrasis Reconsidered. On Verbal Representations of NonVerbal Texts." In Interart Poetics. Essays on the Interrelations of the Arts and Media, eds. Ulla-Britta Lagerroth, Hans Lund and Erik Hedling, I9-33. Amsterdam: Rodopi.

Cuddon, John Anthony. I99I. "Impressionism." In Id., A Dictionary of Literary Terms and Literary Theory, 446. Oxford: Blackwell.

Cygnaeus, Gustaf. I892. “Unga år. Noveller af Karl A. Tavaststjerna.” Åbo Tidning 25 September. ['G. C.'].

—. I900. "Från bokvärlden.” Åbo Tidning I6 June. ['G. C.'].

Dahl, Willy. I981. Stil og struktur. Utviklingslinjer i norsk prosa gjennom 150 år. Bergen: J.W. Eide.

Dahlerup, Pil. I987. “Impressionismen - 'En Unatur, som dog findes i Naturen'.” In Ead., Liv og lyst: artikler og essays, I33-I49. København: Gyldendal.

Deffoux, Léon. I928. “Les Goncourt, Emile Zola et l'impressionnisme.” La Revue mondiale I86: 236-244.

De Lange, Adriaan. I992. "Conrad and Impressionism: Problems and (Possible) 
Solutions." In Conrad's Literary Career. Conrad Eastern and Western Perpectives, eds. Keith Carabine, Owen Knowles and Wieslaw Krajka, 2I-40. Lublin: Maria Curie-Sklodowska University.

De Nardis, Luigi. I957. Impressionismo di Mallarmé. Roma: Edizioni Salvatore Sciascia.

Demoris, René, ed. I993. L'Artiste en représentation. Actes du colloque Paris IIIBologne. I6-I7 avril I99I. Paris: Desjonquières.

Demougin, Jacques, ed. I985. "Impressionnisme." In Dictionnaire historique, thématique et technique des littératures. Littératures française et étrangères, anciennes et modernes, 755. Paris: Larousse.

Deshairs, Léon. I904a. “Impressionister och neoimpressionister, I." Euterpe 5: 5I-56.

—. I904b. "Impressionister och neoimpressionister, II." Euterpe 7: 78-82.

—. I904c. "Impressionister och neoimpressionister, III.” Euterpe 8: 9I-96.

Desprez, Louis. I884. L'Évolution naturaliste. Paris. Tresse.

Drabble, Margaret, ed. 2000. "Impressionism." In The Oxford Companion to English Literature, 515-516. Oxford: Oxford University Press.

Dumora, Florence. 20I2. "L'Impressionnisme entre guillemets." In Impressionnisme et littérature, eds. Gérard Gengembre, Yvan Leclerc and Florence Naugrette, 2735. Rouen: Presses universitaires de Rouen et du Havre.

Edelfelt, Albert. I877. "Bildande konst." Finsk tidskrift 3: 336-343.

Ekelund, Erik. I969. Finlands svenska litteratur 2. Från Åbo brand till sekelskiftet. Helsingfors: Söderström.

Erdman, Nils. I884. Modern realism: en psykologisk litteraturstudie. Stockholm: Seligmann.

Estébanez Calderón, Demetrio. 2004. “Impresionismo.” In Diccionario de términos literarios, 559-56r. Madrid: Alianza.

Estlander, Carl Gustaf. I89o. "Gustaf af Geijerstam: Fattigt folk." Finsk tidskrift 29: 6i3. ['C.G.E.'].

—. I89I. "Helena Westermarck: Ur Studieboken, berättelser och utkast I." Finsk tidskrift 31: 57-60.

-. I892. Helena Westermarck: Ur Studieboken, berättelser och utkast II.” Finsk tidskrift 32: 254-255. ['C.G.E.']

Ferguson, Suzanne. 1979. "The Face in the Mirror: Authorial Presence in the Multiple Vision of Third-Person Impressionist Narrative." Criticism: A Quarterly of Literature and the Arts 2I, 3: 230-250.

-. I994. "Defining the Short Story: Impressionism and Form." In The New Short Story Theories, ed. Charles May, 218-230. Athens: Ohio University Press.

Fibinger, Johannes, and Gerd Lütken. 2004. Litteraturens Veje. København: Gad.

Forssell, Pia. I999. "Helena Westermarck. Tidsskildring och kvinnohistoria." In Finlands svenska litteraturhistoria I, ed. Johan Wrede, 46I-463. Helsingfors / Stockholm: Svenska litteratursällskapet i Finland / Atlantis. 
Fosli, Halvor. I994. Kristianiabohemen. Byet, miljøet, menneska. Oslo: Det norske samlaget.

Geijerstam, Gustaf af. I883. Ur samtiden: literaturstudier. Stockholm: A.W. Björck.

—. I884. "Skuggspel, tidsbilder af Georg Nordensvan." Nya Pressen 3 November.

—. I886. "Literaturkritik. Andra delen af 'Tjänstekvinnans son'.” Nya Pressen 6 October.

—. I889. Utan pängar. In Fattigt folk. Berättelser II, I87-256. Stockholm: Bille. Online at https://litteraturbanken.se/forfattare/GeijerstamG/titlar/FattigtFolkII/sida/I87/ etext. Accessed 25 January 2018.

Genette, Gérard. 1987. Seuils. Paris: Éditions du Seuil.

Gengembre, Gérard, Yvan Leclerc and Florence Naugrette, eds. 20I2. Impressionnisme et littérature. Rouen: Presses universitaires de Rouen et du Havre.

Gfrereis, Heike, ed. I999. “Impressionismus." In Grundbegriffe der Literaturwissenschaft, 89-90. Stuttgart: Metzler.

Goulesque, Florence. 200I. "Impressionnisme poétique chez Marie Krysinska: Esthétique de l'ambiguïé et de démarche féministe." Nineteenth Century French Studies 29, 3\&4: 318-333.

Gravier, Maurice. I967. "Herman Bang et la Peinture." In Växelverkan mellan skönlitteraturen och andra konstarter, The Sixth International Study Conference on Scandinavian Literature, Uppsala, I2-I6 augusti I966, ed. Gunnar Svanfeldt, 9-29. Uppsala: Litteraturhistoriska Institutionen, Uppsala Universitet.

Gruetzner Robins, Anna. 2007. "George Moore's A Modern Lover: Introducing the French Impressionists to London.” French Studies LXI, I: 47-56.

Gunnarsson, Torsten. 2002. “Impressionismen och Norden.” In Id., Impressionismen och Norden. Det sena 1800-talets franska avantgardekonst och konsten i Norden $1870-$ 1920, 9-46. Stockholm: Nationalmuseum.

Gustafson, Alrik. I940. “Impressionistic Realism: Jonas Lie.” In Six Scandinavian Novelists, 25-72. Minneapolis: University of Minnesota Press.

Gynning, Margareta. I997. "Hanna Pauli." In Konstnärsparet Hanna och Georg Pauli, ed. Hans Henrik Brummer, 3I-68. Stockholm: Carlsson.

Hagstrum, Jean Howard. 1958. The Sister Arts. The Tradition of Literary Pictorialism and English Poetry from Dryden to Gray. Chicago / London: The University of Chicago Press.

Hallberg, Peter. I970. “Impressionism.” In Svenskt litteraturlexikon, 257-259. Lund: Gleerup.

Hamon, Philippe. I967. "À propos de l'impressionnisme de Zola." Les Cahiers naturalistes 34: I39-I47.

Harrow, Susan. 20I0. "New Ekphrastic Poetics." French Studies: A Quarterly Review 64, 3: $255-264$.

Hatzfeld, Helmut. 1952. Literature through Art. A New Approach to French Literature. New York: Oxford University Press.

Hauser, Arnold. I999. The Social History of Art IV: Naturalism, Impressionism, the Film Age. London / New York: Routledge. 
Hedén, Erik. I920. “Siri von Essen.” Social-Demokraten 3 July. ['Ek Hn'].

Hedström, Per. 2002. "Det svenska mottagandet av det sena I800-talets franska avantgardekonst." In Impressionismen och Norden. Det sena 1800-talets franska avantgardekonst och konsten i Norden 1870-1920, ed. Torsten Gunnarsson, 47-I29. Stockholm: Nationalmuseum.

Heede, Dag. 2003. "Herman Bang og seksualiseringen af litteraturhistorien. Eller: er impressionismen en homoseksuel fortælleteknik?”. Standart XVII, 4: 33-35.

Heffernan, James A.W. I99I. "Ekphrasis and Representation." New Literary History 22, 2: 297-3I6.

-. I993. Museum of Words. The Poetics of Ekphrasis from Homer to Ashbery. Chicago / London: The University of Chicago Press.

Heidenstam, Verner von, and Oscar Levertin. I890. Pepitas bröllop. En literaturanmälan, Stockholm: Bonnier.

Heitmann, Annegret. I988. “Kunstnere på Skagen: impressionisme i ord og billeder.” In The Modern Breakthrough in Scandinavian Literature 1870-1905, Proceedings of the I6th Study Conference of the International Association for Scandinavian Studies, Gothenburg, August 4-8, eds. Bertil Nolin and Peter Forsgren, 53-6I. Göteborg: Litteraturvetenskapliga institutionen, Göteborgs universitet.

Hintze, Bertel. I942-I944. Albert Edelfelt. Vols. I-III. Helsingfors: Söderström.

'Hj. Ö.'. I899. “Karl A. Tavaststjerna: Efter kvällsbrisen.” Hufvudstadsbladet I7 May.

Holm-Petersen, Niels. I97I. "Udviklingen af impressionismen i Herman Bangs forfatterskab for i885.” Extracta III: I08-II6.

Holmström, Roger. I999. "The Modern Breakthrough's Author and His Publisher: Mikael Lybeck and Werner Söderström.” In Nordic Letters 1870-1910, eds. Michael Robinson and Janet Garton, 335-351. Norwich: Norvik Press.

Hoople, Robin. 2000. In Darkest James: Reviewing Impressionism, 1900-1905. Lewisburg (PA): Bucknell University Press.

Hoppe, Hans. I933. Impressionismus und Expressionismus bei Emile Zola. Münster: Pöppinghaus.

'H.R.'. I90I. “Jonatan Reuter: Berättelser om 'lefvande och döda'.” Finsk tidskrift 50 : $255^{-25} 6$.

Hueffer, Ford Madox. I914a. "On Impressionism I." Poetry and Drama 6: I66-I74.

—. I9I4b. "On Impressionism II." Poetry and Drama 8: 322-333.

Itten, Johannes. I970. The Elements of Color. A Treatise on the Color System of Johannes Itten Based on His Book The Art of Color, ed. Faber Birren. New York: Johan Wiley \& Sons.

Jacobsen, Harry. 1957. Herman Bang. Resignationens digter. København: Hagerup. Johansson, Gotthard. I949. "Strindberg och konsten." Bonniers Litterära Magasin I8: 19-32.

Johansson, Simon Stensson. 20II. Symbolism och impressionism i Ivar Conradsons Skyarne.M.A.thesis, Institutionenförlitteratur, idéhistoriaochreligion, Göteborgs 
universitet. Online at https://gupea.ub.gu.se/handle/2077/27919?locale=sv. Accessed 7 February 2018.

Johnson, J. Theodore Jr. I973. "Literary Impressionism in France: A Survey of Criticism." L'Esprit Créateur XIII, 4: 27I-297.

Juncker, Beth. I996. "Bohemen som metafor." In Nordisk kvindelitteraturhistorie 3, Vide verden 1900-1960, eds. Elisabeth Møller Jensen et al., 8I-89. København: Rosinante.

Jæger, Hans. I886. "Vor literatur." Impressionisten 2.

-. I887. "Albertine og naturalismen." Impressionisten 4.

—, and Christian Krohg, eds., I886-90. Impressionisten I-9.

-. I976. Fra Kristiania-Bohêmen I and II. Oslo: Novus.

Jæger, Henrik. I883. “Om J.P. Jacobsen som novellist.” Nyt Tidsskrift 2: 75-89.

Katz, Tamar. 2000. Impressionist Subjects. Gender, Interiority, and Modernist Fiction in England. Chicago: University of Illinois Press.

Kaufman, Richard. I886. “Modern fransk literatur." Finsk tidskrift 21: 153-I60.

—. ı89o. "Pariser-krönika." Åbo Tidning 9 December.

Kennedy X.J. [Joseph], Dana Gioia and Mark Bauerlein, eds. 2009. "Impressionism.” In Handbook of Literary Terms. Literature, Language, Theory, 8I-82. New York: Longman.

Key, Ellen. I898. "Karl August Tavaststjerna.” Björneborgs tidning 9 July.

Kinnander, Bengt. I939. “Ordstudier i Strindbergs prosa.” Nysvenska studier. Tidskrift för svensk stil- och språkforskning 56: 29-67.

Kirschke, James J. I98I. Henry James and Impressionism. Troy: Whitston.

Klarer, Mario. I999. "Introduction." Word and Image I5, I: I-4.

Kleve, Stella. I884a. Flirtations. Nationaltidende 25 September; 2 October; 9 October.

—. I884b. På bröllopsresa. Dagens Nyheter ig December.

-. I884c. Vinterstycke. Dagens Nyheter I9 December.

-. I885a. Berta Funcke. Stockholm: J. Seligmann \& K.

—. I885b. Förlofning. Skånska Dagbladet 25 February; 27 February; 4 March.

-. I886a. Hemkomst. Ny illustrerad tidning.

—. I886b. “Om efterklangs- och indignationslitteraturen i Sverige." Framåt I September.

—. I886c. Pyrrhussegrar. Framåt I5 October.

-. I886d. Vid Beau-Rivage. Framåt I August.

-. I886-87. Ensam. Norden. Illustrerad skandinavisk revue, II3ff.

—. I888a. Alice Brandt. En qvinnoprofil. Helsingborg: Österling.

-. I888b. Morgondrömmar. Skånska aftonbladet 9 June.

Konttinen, Riitta. 1996. Helena Westermarck 1857-1938. Swedish transl. by Bianca Gräsbeck. Åbo: Åbo konstmuseums publikationer.

Kris Ernst, and Otto Kurtz. 1979. Legend, Myth, and Magic in the Image of the Artist. A Historical Experiment. Preface by Ernst Hans Josef Gombrich. New Haven / London: Yale University Press. 
Krohg, Christian. I886. Om den bildende kunst som led i kulturbevagelsen. Kristiania: Huseby \& Co.

—. I889. "Den tredie Generation." Verdens Gang 27 April.

—. I988. "Edvard Munch. En analyse." In A fylle sin sjel med tidens tanke. Artikler og portretter, 38-45. Oslo: Gyldendal.

—. I995. “Den bildende kunst som ledd i kulturbevegelsen." In Bohemene taler, ed. Harry Hansen, 77-I2I. Oslo: Fjørtoft.

Kronegger, Maria Elizabeth [Marlies]. I973a. Literary Impressionism. New Haven: College \& University Press.

-. I973b. "The Multiplication of the Self from Flaubert to Sartre." L'Esprit Créateur XIII, 4: 310-3I9.

—. I984. "Literary Impressionism and Phenomenology: Affinities and Contrasts." In Analecta Husserliana. The Yearbook of Phenomenological Research, XVII: The Existential Coordinates of the Human Condition: Poetic - Epic - Tragic. The Literary Genre, ed. Anna-Teresa Tymieniecka, 52I-553. Dordrecht / Boston / Lancaster: Reidel.

Kuiper, Kathleen, ed. I995. “Impressionism.” In Merriam-Webster's Encyclopedia of Literature, 583. Springfield: Merriam-Webster.

Laforgue, Jules. I902-03. “L’Impressionnisme.” In Id., Mélanges posthumes. Oeuvres complètes III, I33-I45. Paris: X.

-. I956. "Impressionism: the Eye and the Poet." English transl. by William Jay Smith. In Art News 55, 3: 43-45. Online at https://www.msu.edu/course/ha/240/ laforque.htm. Accessed 7 February 2018.

Lamm, Martin. 1963. August Strindberg. Stockholm: Aldus / Bonnier.

Langenbruch, Beate. 20I2. "L'Impressionnisme et la littérature allemande. Les modalités d'un double transfert culturel." In Impressionnisme et littérature, eds. Gérard Gengembre, Yvan Leclerc and Florence Naugrette, I05-I22. Rouen: Presses universitaires de Rouen et du Havre.

Larsen, Finn S. 1973. “En Impressionist fra Baroktiden?”. Kritik 25: I7-33.

Leopold, Irene I907. "Herman Bang: De uden Fadreland." Finsk tidskrift 62: 410-4I4. Lethbridge, Robert. 20II. "Impressionism: Art, Literature, and History, I870-I9I4." In The Cambridge History of French Literature, eds. William Burgwinkle, Nicholas Hammond and Emma Wilson, 53I-540. Cambridge: Cambridge University Press.

Lièvre-Crosson, Elisabeth. I999. De l'impressionnisme à l'expressionnisme. Toulouse: Milan.

Lindberg, Bo. 1998. “Måleri från romantik till realism.” In Konsten i Finland. Från medeltid till nutid, ed. Bengt von Bonsdorff, I70-I99. Esbo: Schildt.

Lindblad, Göran. I924. August Strindberg som berättare. Studier i hans tidigare prosa. Stockholm: Norstedt.

Lindén, Axel. 2009. Förnimmelser: en fenomenologisk analys av Herman Bangs författarskap. Lund: Ellerström.

Linder, Sten. I936. Strindberg, Ibsen och andra. Litteraturhistoriska essäer. Stockholm: 
Bonnier.

Lindholm, Bernt. I870. "Bref från Paris." Helsingfors Dagblad I8 February.

Lingebrandt, Ann. 20II. Stella Kleve. Det moderna genombrottets enfant terrible. Umeå: h:ström - Text \& Kultur.

'LL'. I974. “Impressionisme.” In Gyldendals Litteraturleksikon II, eds. Henning Harmer and Thomas Jørgensen, I90-I9I. København: Gyldendal.

Lodge, David. I992. "Showing and Telling." In Id., The Art of Fiction, I2I-I24. London: Penguin.

Loesch, Georg. I9I9. Die impressionistische Syntax der Goncourt. Nürnberg: Benedikt Hilz.

Lombardi, Maria Cristina. 20I2. "August Strindberg e il mito del colore: $I$ vårbrytningen." AION. Sezione germanica XXII, I-2: 85-IO4.

Lotass, Lotta. [s. d.] "Mathilda Roos (I852-I908)." https://litteraturbanken.se/ forfattare/RoosM. Accessed 25 January 2018.

Lund, Hans. I982. Texten som tavla. Studier i litterär bildtransformation. Lund: Liber.

-. I993. Impressionism och litterär text. Stockholm / Stehag: Symposion.

Lundevall, Karl-Erik. I953. Från åttital till nittital: om åttitalslitteraturen och Heidenstams debut och program. Stockholm: Almqvist \& Wiksell.

Lybeck, Mikael. I893. Allas vår Margit. Stockholm: Bonnier.

-. I900. Den starkare. Helsingfors: Waseniuska bokhandeln.

Lykke, Jon. 2000. I møte mellom ord og bilde. Kristiansand: Høyskoleforlaget.

Malling, Mathilda. I920. Uppfostran och inflytande: 1864-1885. København: Græbes boktryckeri.

Malmanger, Magne: I987. “'Impressionismen’ og Impressionisten. Chr. Krohg og det moderne gjennombrudd i i880-årene.” In Christian Krohg, eds. Oscar Thue and Ingeborg Wikborg, 3I-49. Oslo: Nasjonalgalleriet.

Malmström, Sten. I968. "Impressionistisk och symbolistisk form. Två dikter av Vilhelm Ekelund.” In Id., Stil och versform i svensk poesi 1900-1926. Valda analyser och problem, I32-I52. Stockholm: Svenska akademiens handlingar.

Marcuse, Herbert. I978. Der deutsche Künstlerroman. Frühe Aufsätze. In Id., Schriften I. Frankfurt am Main: Suhrkamp.

Marhold, Hartmut. I985. Impressionismus in der deutschen Dichtung. Frankfurt am Main / Bern / New York: Peter Lang.

—. ed. I99I. Gedichte und Prosa des Impressionismus. Stuttgart: Reclam.

Matthews, J.H. I96ı. "L’Impressionnisme chez Zola: Le Ventre de Paris.” Le Français moderne XXIV, 3: I99-205.

Matz, Jesse. 200I. Literary Impressionism and Modernist Aesthetics. Cambridge: Cambridge University Press.

-. 2012. "Pseudo-impressionism?", In The Legacies of Modernism. Historicising Postwar and Contemporary Fiction, ed. David James, II4-I32. Cambridge: Cambridge University Press.

May, Brian. I994. "Ford Madox Ford and the Politics of Impressionism." Essays in 
Literature 21: 82-96.

Mickwitz, Gerda von. I885. Solglöd och andra skizzer. Helsingfors: Edlund.

Mitchell, William John Thomas. 1994. Picture Theory. Essays on Verbal and Visual Representation. Chicago: University of Chicago Press.

Moser, Ruth. I952. L'Impressionnisme français: peinture, littérature, musique. Genève: Droz.

Muller, Herbert. I938. "Impressionism in Fiction: Prism vs Mirror." The American Scholar 7: 355-367.

Møller Kristensen, Sven. I938. Astetiske studier i dansk fiktionsprosa 1870-1900. København: Levin \& Munksgaard.

-. I955. Impressionismen i dansk prosa 1870-1900. Med et tilloeg om stiludviklingen efter år 1900. København: Gyldendal.

—. I967. "Vejledning." In Herman Bang, Ved Vejen, I45-156. København: Gyldendal.

Mørstad, Erik. I99I. "Christian Krohgs kunstteori i I880-årene.” Kunst og Kultur 2: 69-107.

Nagel, James. I980. Stephen Crane and Literary Impressionism. University Park / London: The Pennsylvania State University Press.

Newton, Joy. I973. "Emile Zola and the French Impressionist Novel." L'Esprit Créateur XIII: 4, 320-328.

Ney, Birgitta. I993a. Bortom berättelserna: Stella Kleve - Mathilda Malling. Stockholm / Stehag: Symposion Graduale.

-. I993b. "Leg på grænsen til det forbudte." In Nordisk kvindelitteraturhistorie 2, Faderhuset 1800-tallet, eds. Elisabeth Møller Jensen et al., 540-547. København: Rosinante.

-. 2005. "Impressionism och modernitet hos Stella Kleve." In Det moderna genombrottets prosa [sju analyser], ed. Yvonne Leffler, IoI-IIo. Lund: Studentlitteratur.

Nielsen, Torben. I984. "På tourné med Herman Bang." In Från vän till vän. Festskrift till Olof Mustelin - historiker och bibliotekarie - på hans 6o-års dag, ed. Torbjörn Söderholm, 245-256. Åbo: Åbo Akademis Bibliotek.

Nilsson, Torbjörn. I965. Impressionisten Herman Bang: studier i Herman Bangs författarskap till och med Tine. Stockholm: Norstedt.

Nordensvan, Georg. I883a. "Impressionism." Ny Illustrerad Tidning I9 May.

—. I883b. "Studier i modern konst. Parisersalongen I883, I-II." Finsk tidskrift I4: $410-420$.

一. I883c. "Studier i modern konst. Parisersalongen I883, III-IV." Finsk tidskrift I5: I7-29.

—. I884. Skuggspel. Tidsbilder. Stockholm: Häggström.

—. I885. "Sveriges konst i dess yngsta skede." Finsk tidskrift I9: 70-80.

—. I890. "Bref från Sverige." Finsk tidskrift 28: 477-485.

—. I891. "Bref från Sverige." Finsk tidskrift 31: 394-399.

—. I892. "Bref från Sverige." Finsk tidskrift 6: 404-4Io. 
—. I894a. Aja. In Id., Tre små romaner. Stockholm: Bonnier.

-. I894b. Aja. Berättelse. In Idun. Praktisk veckotidning för kvinnan och hemmet 5: 36-37; 6: 47-48; 7: 54-55; 8: 63-64; 9: 7I-72; го: 79-80; пг: 87-88; г2: 95-96; г3: I03-I04. Online at http://www.ub.gu.se/kvinn/digtid/o7/ı894/index.xml (pages in issue no. I4 missing). Accessed 25 January 2018.

Olsson, Berndt. I983a. “Ord hur fattiga. Vilhelm Ekelund och språket.” Svensk Litteraturtidskrift 46, 3: 3-I9.

-. I983b. "Stil och stiltypologier. Presentation av några problem och ett forskningsprojekt." In Om stilforskning. Föredrag och diskussionsinlägg vid Vitterhetsakademins symposium 16-18 november 1982, ed. Örjan Lindberger, 6982. Stockholm: Almqvist \& Wiksell.

'O-o’. I897. “Ola Hansson: Kåserier i musik.” Hufvudstadsbladet I2 December.

Parkes, Adam. 20II. A Sense of Shock: The Impact of Impressionism on Modern British and Irish Writing. New York: Oxford University Press.

Peters, John G. 200I. Conrad and Impressionism. Cambridge: Cambridge University Press.

Pouzet-Duzer, Virginie. 2008. L'Impressionnisme littéraire: capture de l'insaissable. PhD dissertation, Department of Romance Studies. Durham (NC): Duke University.

- 2013. L'Impressionnisme littéraire. Saint-Denis: Presses Universitaires de Vincennes.

Pullwer, Christine. I991. Impressionistische Tendenzen in Christian Krohgs Albertine als Roman und Gemälde. M.A. thesis, Die Philosophische Fakultät, ChristianAlbrechts Universität zu Kiel.

'-r'. I886. “Verdandi. Strödda blad." Finsk Tidskrift 21: 59-6I.

'Red'. I886. Impressionisten 2, December.

Reimer, Melissa C. 2009. "Katherine Mansfield: Colonial Impressionist." Oculus I: I4-29.

-. 2010. Katherine Mansfield: A Colonial Impressionist. PhD thesis. Christchurch: University of Canterbury. Online at http://hdl.handle.net/10092/5289. Accessed 7 February 2018.

—. 20II. "A Literary Impressionist?: Mansfield's Painterly Vignettes." Katherine Mansfield Studies 3: 35-50.

Reitala, Aimo. 1967. Victor Westerholm. Helsingfors: Söderström.

—. I997. "Edelfelt, Albert (I854-I905)." English transl. by Roderick Fletcher. https:// kansallisbiografia.fi/english/person/3217. Accessed 25 January 2018.

Remak, Henry H.H., and Ulrich Weisstein, eds. 1968. Symposium in Literary Impressionism. In Yearbook of Comparative and General Literature I7: 40-72. Bloomington (IN): Indiana University Press. Online at https://archive.org/ details/yearbookofcomparoI7776mbp. Accessed 7 February 2018.

Richter, Elise. I927. "Impressionismus, Expressionismus und Grammatik." In 
Zeitschrift für romanische Philologie 47: 349-37I.

Ringbom, Sixten. I998. “Symbolism, syntetism och Kalevalastil (Storfurstendömet).” In Konsten i Finland. Från medeltid till nutid, ed. Bengt von Bonsdorff, 216-227. Esbo: Schildt.

Robertson, Ritchie. I997. "From Naturalism to National Socialism (I890-I945)." In The Cambridge History of German Literature, ed. Helen Watanabe-O’Kelly, 327392. Cambridge: Cambridge University Press.

Roos, Mathilda. I889. Familjen Verle. En skildring. Stockholm: Bonnier. Online at http://hdl.handle.net/2077/37218. Accessed 7 February 2018.

Rowe, John Carlos. 2009. "Phenomenological Hermeneutics. Henry James and Literary Impressionism." In Id., The Theoretical Dimensions of Henry James, I892I8. Madison: University of Wisconsin Press.

Rubin, James Henry. 20I2. "L'Impressionnisme et le regime du visual." In Impressionnisme et littérature, eds. Gérard Gengembre, Yvan Leclerc and Florence Naugrette, 7-I4. Rouen: Presses universitaires de Rouen et du Havre.

Ruin, Hans. I964. I konstens brännspegel. Från impressionismens konst till diktaturernas. Lund: Gleerup.

Ruskin, John. I997. Elements of Drawing. London: The Herbert Press.

Rykkja, Olav. I972. Cora Sandels impresjonisme. En undersøkelse av stilen $i$ Alberte-trilogien. M.A. thesis. Oslo: Universitetet i Oslo.

Saunders, Max. 2004a. "Modernism, Impressionism, and Ford Madox Ford's The Good Soldier." Études anglaises 57, 4: 42I-437.

-. 2004b. "Reflections on Impressionist Autobiography: James, Conrad, and Ford." In Inter-relations: Conrad, James, Ford, and Others, ed. Wieslaw Krajka, 7-4I. Columbia / Lublin: Columbia University Press.

- 2005a. "Ford, the City, Impressionism and Modernism." In Ford Madox Ford and the City, ed. Sara Haslam, 67-80. Amsterdam: Rodopi.

-. 2005b. "Literary Impressionism." In A Companion to Modernist Literature and Culture, eds. David Bradshaw and Kevin J.H. Dettmar, 204-2II. Oxford: Blackwell.

-. 2008a. "Ford and Impressionism." In Ford Madox Ford: Literary Networks and Cultural Transformations, eds. Andrzej Gasiorek and Daniel Moore, I5I-I66. Amsterdam / New York: Rodopi / The Ford Madox Ford Society.

-. 2008b. "Impressionism, Fiction, and the Location of the Ethical." In Ethics in Culture: The Dissemination of Values through Literature and Other Media, eds. Astrid Erll, Herbert Grabes and Ansgar Nünning, 299-316. Berlin: Walter de Gruyter \& Co.

—. 2008c. "Literary Impressionists." In Oxford Dictionary of National Biography. Oxford: Oxford University Press. Online at http://www.oxforddnb.com/view/ theme/96337. Accessed 7 February 2018.

-. 20II.“Ford's Thought-experiments: Impressionism, Place, History, and 'the frame of mind that is Provence." In Ford Madox Ford, France and Provence, 
eds. Dominique Lemarchal and Claire Davison-Pégon, 259-276. Amsterdam / Kenilworth: Rodopi.

-. 20I3. "Imagism vs. Impressionism: Ezra Pound and Ford Madox Ford." In Imagism: Essays on Its Initiation, Impact and Influence, eds. John Gery, Daniel Kempton and Harry Robert Stoneback, 93-Io6. New Orleans: University of New Orleans Press.

Schneider, Hans. I934. Maupassant als Impressionist: in Une Vie, La Maison Tellier, Au Soleil. Münster: Pöppinghaus.

Schnitzer, Deborah. 1988. The Pictorial in Modernist Fiction from Stephen Crane to Ernest Hemingway. Ann Arbor (MI): UMI Research Press.

Schultén, Arvid af. I887. "Strindberg och hans sista arbete Fadren." Nya Pressen 23 October. ['Arv. af S.'].

'Scylla och Charybdis'. I883. "Bildande konst." Finsk tidskrift I5: 47I-476.

'Se'. I907. “Svenska teatern. Djävulskyrkan.” Fritt Folk I2 January.

Sitzia, Émilie. 2004. L'Artiste entre mythe et realité dans trois oeuvres de Balzac, Goncourt et Zola. Åbo: Åbo Akademi University Press.

Sjöwall, Staffan. I967. “Jonas Lies betydelse för Herman Bangs författarskap.” Edda LXVII: 213-2I6.

Skram, Erik. I89o. "Et literært Rundskue." Tilskueren 25: 478-49I.

Smith, David Woodruff. 2013. "Phenomenology." In Stanford Encyclopedia of Philosophy, ed. Edward N. Zalta. http://plato.stanford.edu/entries/phenomenology/. Accessed 2 February 2018.

'Spectator'. I9I0. "Ryska bref, IV. Strömningar inom den modärna litteraturen." Tammerfors Nyheter I5 June.

Sprengel, David. I902. De nya poeterna (80-talet). Dokument och kåserier. Stockholm: Gernandt.

Storskog, Camilla. 2003. “'Scrivere la propria vita'. Una lettura dei diari di Edvard Munch.” ACME LVI, II: I69-I98.

-. 20II. "Literary Impressionism and Finland. A Critical Digest." Scandinavian Studies 83, 3: 387-413.

-. 20I2. "Paris from a Window. Impressionism in Helena Westermarck's Short Story Aftonstämning (1890)." Scandinavica 5I, I: 6-33.

Stowell, H. Peter. I980. Literary Impressionism. James and Chekov. Athens (GA): The University of Georgia Press.

—. I984. "Phenomenology and Literary Impressionism: the Prismatic Sensibility." In Analecta Husserliana. The Yearbook of Phenomenological Research XVII: The Existential Coordinates of the Human Condition: Poetic - Epic - Tragic. The Literary Genre, ed. Anna-Teresa Tymieniecka, 535-544. Dordrecht / Boston / Lancaster: Reidel.

Strindberg, August. 1876a. “Från Café de l'Ermitage till Marly-le-Roi och så vidare, I.” Dagens Nyheter 30 November. Also in Id., 2009. Samlade Verk 7: Kulturhistoriska studier, eds. Per Stam and Bo Bennich Björkman, III-II5. Stockholm: Norstedt. Online at https://litteraturbanken.se/forfattare/StrindbergA/titlar/ 
KulturhistoriskaStudier/sida/ıı/etext. Accessed 22 January 20 I8.

—. I876b. “Från Café de l'Ermitage till Marly-le-Roi och så vidare, II”. Dagens NYheter 9 December. Also in Id., 2009. Samlade Verk 7: Kulturhistoriska studier, eds. Per Stam and Bo Bennich Björkman, II5-II9. Stockholm: Norstedt. Online at https:// litteraturbanken.se/forfattare/StrindbergA/titlar/KulturhistoriskaStudier/ sida/II5/etext. Accessed 22 January 2018.

—. I920. "Brev till Gauguin." Swedish transl. by William Molard. In Id., Samlade skrifter 54: Efterslåtter. Berättelser, dikter, artiklar, ed. John Landquist, 325-329. Stockholm: Bonnier. Online at www.runeberg.org/strindbg/eftersl/0325.html. Accessed 7 February 2018.

-. I981. Samlade Verk 2: I vårbrytningen. En berättelse från Stockholms skärgård. Från havet. Här och där. Från Fjärdingen och Svartbäcken, ed. Carl Reinhold Smedmark. Stockholm: Almqvist \& Wiksell.

- I984. Samlade Verk 27: Fadren, Fröken Julie, Fordringsägare, ed. Gunnar Ollén. Stockholm: Almqvist \& Wiksell.

—. I994. Samlade Verk 52: Ensam. Sagor, ed. Ola Östin. Stockholm: Norstedt.

-. I997. Samlade Verk 54: Historiska miniatyrer, ed. Conny Svensson. Stockholm: Norstedt.

-. 2000. Samlade Verk 67: En blå bok. Avdelning III. En extra blå bok. Register till En blå bok, ed. Gunnar Ollén. Stockholm: Norstedt. Online at https:// litteraturbanken.se/forfattare/StrindbergA/titlar/EnBlaBok3/sida/I239/etext. Accessed 7 February 2018.

-. 2oıоa. "Brev till Gauguin." Swedish transl. by Lars Strömberg. In Id., Samlade Verk 34: Vivisektioner II, eds. Gunnel Engwall and Per Stam, II2-II5. Stockholm: Bonnier. Online at https://litteraturbanken.se/forfattare/StrindbergA/titlar/ Vivisektioner2/sida/ıI2/etext. Accessed 7 February 2018.

-. 20Iob. "Lettre à Gauguin." In Id., Samlade Verk 34: Vivisektioner II, eds. Gunnel Engwall and Per Stam, 25I-254. Stockholm: Bonnier. Online at https:// litteraturbanken.se/forfattare/StrindbergA/titlar/Vivisektioner2/sida/25I/etext. Accessed 7 February 2018.

—. 2012. Samlade verk 24: Hemsöborna, eds. Camilla Kretz and Hans Söderström. Stockholm: Norstedt.

Svensson, Conny. I985. Åttitalet och konstnärsromanen. Lund: Doxa.

Sypher, Wylie. I960. “The Impressionist Experiment.” In Id., Rococo to Cubism in Art and Literature, I69-I95. New York: Random House.

Söderström, Göran. I972. Strindberg och bildkonsten. Stockholm: Forum.

Sørensen, Villy. I986. “Efterskrift.” In Herman Bang, Tine, ed. Marie Hvidt, I57-I78. København: Borgen.

Tavaststjerna, Karl August. I884. "Bref från Paris.” Nya Pressen ig February. ['stst']. -. I892. Impressionisten. In Id., Unga år, II-58. Fredrikshamn: Hagelstam.

Thomsen, Hans Hagerdorn. 2003. Det lukkede rum. Rum og bevidsthed i Herman Bangs og Tom Kristensens romaner. Odense: Syddansk Universitets forlag. 
Thon, Louise. I928. Die Sprache des deutschen Impressionismus. München: Hueber. Tikkanen, Johan Jakob. I904a. “Den moderna impressionismen, I.” Hufvudstadsbladet I4 February.

—. I904b. "Den moderna impressionismen, II." Hufvudstadsbladet 23 February.

Toftegaard Pedersen, Arne. 2002. Det marginaliserede gennembrud. Tre moderne svensksprogede romaner fra 188oernes Finland. Åbo: Åbo Akademis förlag.

Torgovnick, Marianna. I985. The Visual Arts, Pictorialism, and the Novel: James, Lawrence, and Woolf. Princeton: Princeton University Press.

Usselmann, Henri. 1982. “Strindberg et l'Impressionnisme." Gazette des Beaux Arts I359: I53-I62.

Valazza, Nicolas. 20I3. Crise de plume et souveraineté du pinceau. Écrire la peinture de Diderot à Proust. Paris: Classiques Garnier.

Van Gunsteren, Julia. I990. Katherine Mansfield and Literary Impressionism, Amsterdam: Rodopi.

Venturi, Lionello. I94I. "The Aesthetic Idea of Impressionism." The Journal of Aesthetics and Art Criticism I: 34-45.

Vouilloux, Bernard. 2000. "L'Impressionnisme littéraire: une révision." Poétique: Revue de théorie et d'analyse littéraires I2I: 6I-92.

—. 2ог2a. "L'Impressionnisme littéraire, un mythe fécond." In Impressionnisme et littérature, eds. Gérard Gengembre, Yvan Leclerc and Florence Naugrette, I7-25. Rouen: Presses universitaires de Rouen et du Havre.

- 20I2b. "Pour en finir avec l'impressionnisme littéraire. Un essai de métastylistique." Questions de style 9: I-25.

Wanlin, Nicolas. 20I2. "Comment se construit l'idée d'impressionnisme poétique (sur le cas de Verlaine).” In Impressionnisme et littérature, eds. Gérard Gengembre, Yvan Leclerc and Florence Naugrette, I43-I5I. Rouen: Presses universitaires de Rouen et du Havre.

Watt, Ian. I980. Conrad in the Nineteenth Century. London: Chatto \& Windus.

-. I975. "Pink Toads and Yellow Curs: An Impressionist Narrative Device in Lord Jim." In Joseph Conrad Colloquy in Poland 5-12 September 1972, ed. Róża Jabłkowska, II-3I. Warsaw: Polish Academy of Sciences.

Westermarck, Helena: I880. "Brev till Constance Westermarck" 4 April. Unpublished. Handskriftsavdelningen: Åbo Akademi.

-. I884a. "Den realistiska riktningen i den franska romanen." Finsk tidskrift I7: IOIII6 and I8I-I94. ['H-a'].

—. I884b. "Från Parisersalongen I884, I." Finsk tidskrift I6 (förra halfåret): 475-480. ['H-a'].

—. I884c. "Från Parisersalongen I884, II.” Finsk tidskrift I7 (senare halfåret): I52I6o. ['H-a'].

—. I89oa. Aftonstämning. In Ead., Ur studieboken: berättelser och utkast I, 25-35. 
Borgå: Söderström.

—. I89ob. I marginalen af en museikatalog. In Ead., Ur studieboken: berättelser och utkast I, 57-76. Borgå: Söderström.

-. I89oc. Ur studieboken, berättelser och utkast I. Borgå: Söderström.

-. I89I. Ur studieboken, berättelser och utkast II. Borgå: Söderström.

—. I892. "Två moderna romaner." Finsk tidskrift 33: IOI-II5.

—. I893. "Salongerna i Paris våren 1893." Finsk tidskrift 34: 442-455.

-. I94I. Mina levnadsminnen. Helsingfors: Söderström.

Wenzel, Daniel. I928. Der literarische Impressionismus dargestellt an der Prosa Alphonse Daudets. München: Straub.

Wiljanen, Anna-Maria. 20I4. «Nej, i sanning, ett bättre ställe hade den unga målaren ej kunnat hamna på». Önningeby konstnärskoloni och de mångfacetterade sociala nätverkens interaktion. Helsingfors: Finlands Nationalgalleris publikationer.

Wittgenstein, Ludwig. I953. Philosophical Investigations. Oxford: Basil Blackwell.

'W. S.'. I892. "Nyare böcker, inhemska och utländska." Hufvudstadsbladet I2 October. 'W-t'. I892. "Literatur." Kotka notis- och annonsblad 29 September.

Yacobi, Tamar. I995. "Pictorial Models and Narrative Ekphrasis." Poetics Today I6: $599-646$.

-. I998. “The Ekphrastic Model: Forms and Functions.” In Pictures into Words: Theoretical and Descriptive Approaches to Ekphrasis, eds. Valerie Kay Robillard and Els Jongeneel, 2I-34. Amsterdam: VU University Press.

Yelland, Hedley Lawry, Stanley Clarence Jones, and Keith Sheppard Williams Easton. I983. “Impressionism.” In A Handbook of Literary Terms, 90. London / Sydney / Melbourne: Angus \& Robertson.

Zerlang, Poul. I985. Dansk littercer opslagsbog. København: Gad.

Zibrandtsen, Marianne. 2003. "Agnes Henningsen." http://www.kvinfo.dk/ side/I70/bio/425/. Accessed 23 January 2018.

Østby, Leif. I966. Norges kunsthistorie. Oslo: Gyldendal.

\section{ANONYMOUS AUTHORS:}

I886. “(Albertine).” Nya Pressen 29 December. I886. “Från Skandinavien.” Nya Pressen 29 December. ı886. “Några litterära förhållanden.” Östra Finland 3 July. I887. "Bref från Kristiania. (Från "Finlands" korrespondent)." Finland 24 April. I887. "De Skandinaviska länderna." Finland 6 January. I887. "Från Skandinavien." Nya Pressen 29 January. I889. "Bohêmbud." Impressionisten 8, February. 
I889. "Litterära och vetenskapliga samfund i S:t Petersburg (Bref till H:fors Dagblad)." Helsingfors Dagblad 3 March.

ı89ı. "Svenska litteratursällskapets möte." Nya Pressen 6 February.

I894. "Literatur o konst. Svenskt omdöme om finska författares böcker.” Nya Pressen I8 March.

I894. Åbo Tidning I4 February.

I900. "Finska författarsilhouetter enligt E. Braunswetter." Hufvudstadsbladet 24 February.

I900. "Om Mikael Lybecks bok Den starkare." Hufvudstadsbladet 8 December.

I90I. "Literatur, konst och konstnärer." Hufvudstadsbladet 3 February.

I902. Hufvudstadsbladet 4 July.

WEBSITES:

"Delayed decoding”. http://www.oxfordreference.com/view/Io.Io93/acref/9780I 986042II.001.0001/acref-97801986042II-e-oro2. Accessed 22 October 2014.

DIGI National Library's Digital Collections. http://digi.lib.helsinki.fi/sanomalehti/ search. Accessed 7 February 2018.

"Dusseldorf school". https://www.britannica.com/topic/Dusseldorf-school. Accessed 25 January 2018.

"Painting School of Düsseldorf". http://www.kettererkunst.com/dict/paintingschool-of-dusseldorf.php. Accessed 25 January 2018.

“The Boulevard Montmartre at Night". http://www.nationalgallery.org.uk/paintings/ camille-pissarro-the-boulevard-montmartre-at-night. Accessed 25 January 2018. 



\title{
Titoli della collana
}

\author{
| I | \\ Liana Nissim \\ Vieillir selon Flaubert
}

$|2|$

Simone Cattaneo

La 'cultura X'. Mercato, pop e tradizione.

Juan Bonilla, Ray Loriga e Juan Manuel de Prada

\section{$|3|$}

Oleg Rumyantsev and Giovanna Brogi Bercoff (eds.)

The Battle of Konotop 1659: Exploring Alternatives in East European History

$$
|4|
$$

Irina Bajini, Luisa Campuzano y Emilia Perassi (eds.)

Mujeres y emancipación de la América Latina y el Caribe en los siglos XIX y XX

\section{$|5|$}

Claire Davison, Béatrice Laurent, Caroline Patey and Nathalie Vanfasse (eds.)

Provence and the British Imagination

$$
|6|
$$

Vincenzo Russo (a cura di)

Tabucchi o Del Novecento 
Lidia De Michelis, Giuliana Iannaccaro e Alessandro Vescovi (a cura di) Il fascino inquieto dell'utopia.

Percorsi storici e letterari in onore di Marialuisa Bignami

$$
\begin{aligned}
& \qquad|8| \\
& \text { Marco Castellari (a cura di) } \\
& \text { Formula e metafora. }
\end{aligned}
$$

Figure di scienziati nelle letterature e culture contemporanee

$$
\text { | } 9 \text { | }
$$

Damiano Rebecchini and Raffaella Vassena (eds.)

Reading in Russia. Practices of reading and literary communication, 1760-1930

$$
\text { | Iо | }
$$

Marco Modenesi, Maria Benedetta Collini, Francesca Paraboschi (a cura di)

La grâce de montrer son âme dans le vêtement.

Scrivere di tessuti, abiti, accessori. Studi in onore di Liana Nissim (Tomo I)

$$
\text { | II | }
$$

Marco Modenesi, Maria Benedetta Collini, Francesca Paraboschi (a cura di)

La grâce de montrer son âme dans le vêtement.

Scrivere di tessuti, abiti, accessori. Studi in onore di Liana Nissim (Tomo II)

$$
\text { | I2 | }
$$

Marco Modenesi, Maria Benedetta Collini, Francesca Paraboschi (a cura di)

La grâce de montrer son âme dans le vêtement. Scrivere di tessuti, abiti, accessori. Studi in onore di Liana Nissim (Tomo III) 
Nicoletta Brazzelli

L'Antartide nell'immaginario inglese.

Spazio geografico e rappresentazione letteraria

$$
\text { | I4 | }
$$

Valerio Bini, Marina Vitale Ney (eds.)

Alimentazione, cultura e società in Africa. Crisi globali, risorse locali

$$
\text { | I5 | }
$$

Andrea Meregalli, Camilla Storskog (eds.)

Bridges to Scandinavia

$$
\text { | I6 | }
$$

Paolo Caponi, Mariacristina Cavecchi, Margaret Rose (eds.)

ExpoShakespeare.

Il Sommo gourmet, il cibo e i cannibali

$$
\text { | I7 | }
$$

Giuliana Calabrese

La conseguenza di una metamorfosi

Topoi postmoderni nella poesia di Luis García Montero

$$
\text { | I8 | }
$$

Anna Pasolini

Bodies That Bleed

Metamorphosis in Angela Carter's Fairy Tales

$$
\text { | I9 | }
$$

Fabio Rodríguez Amaya

La Política de la mirada.

Felisberto Hernández hoy 


$$
\begin{gathered}
|20| \\
\text { Elisabetta Lonati } \\
\text { Communicating Medicine. }
\end{gathered}
$$

British Medical Discourse in Eighteenth-Century Reference Works

$$
|2 \mathrm{I}|
$$

Marzia Rosti y Valentina Paleari (eds.)

Donde no habite el olvido.

Herencia y transmisión del testimonio. Perspectivas socio-jurídicas

$$
|22|
$$

A.M. González Luna y A. Sagi-Vela (eds.)

Donde no habite el olvido.

Herencia y transmisión del testimonio en México y Centroamérica

$$
|23|
$$

Laura Scarabelli y Serena Cappellini (eds.)

Donde no habite el olvido.

Herencia y transmisión del testimonio en Chile

$$
|24|
$$

Emilia Perassi y Giuliana Calabrese (eds.)

Donde no habite el Olvido.

Herencia y transmisión del testimonio en Argentina

$$
|25|
$$

Camilla Storskog

Literary Impressionisms.

Resonances of Impressionism in Swedish and Finland-Swedish Prose 1880-1900 